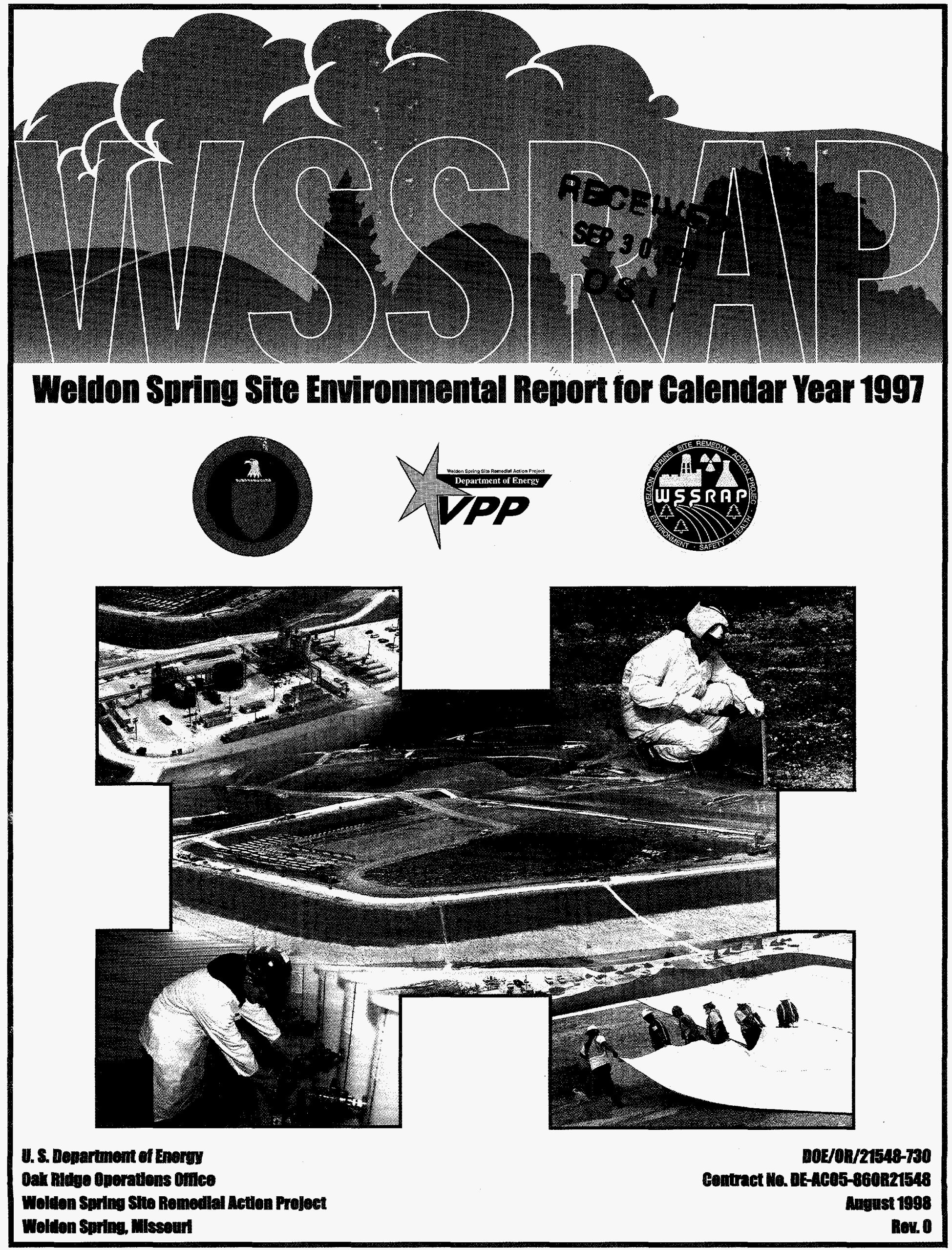




$$
D O E / O R / 21548--730
$$

DOE/OR/21548-730

CONTRACT NO. DE-AC05-86OR21548

\section{WELDON SPRING SITE ENVIRONMENTAL REPORT FOR CALENDAR YEAR 1997}

WELDON SPRING SITE REMEDIAL ACTION PROJECT WELDON SPRING, MISSOURI

\section{AUGUST 1998}

REV. 0

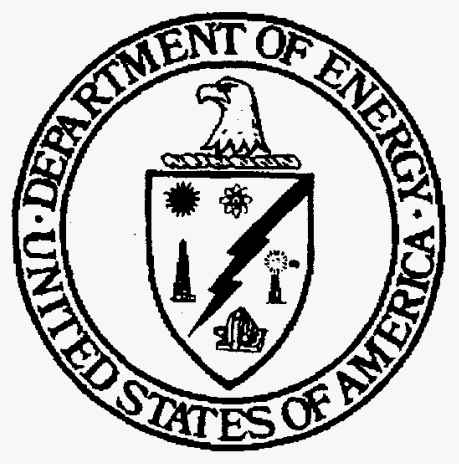

U.S. Department of Energy Oak Ridge Operations Office Weldon Spring Site Remedial Action Project

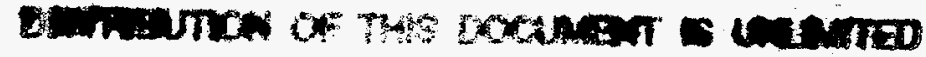


081198

MORRISON KNUDSEN CORPORATION Environmental/Government Group

Weldon Spring Site Remedial Action Project Contract No. DE-AC05-860R21548

Rev. No. 0

PLAN TITLE: Weldon Spring Site Environmental Report for Calendar Year 1997

APPROVALS
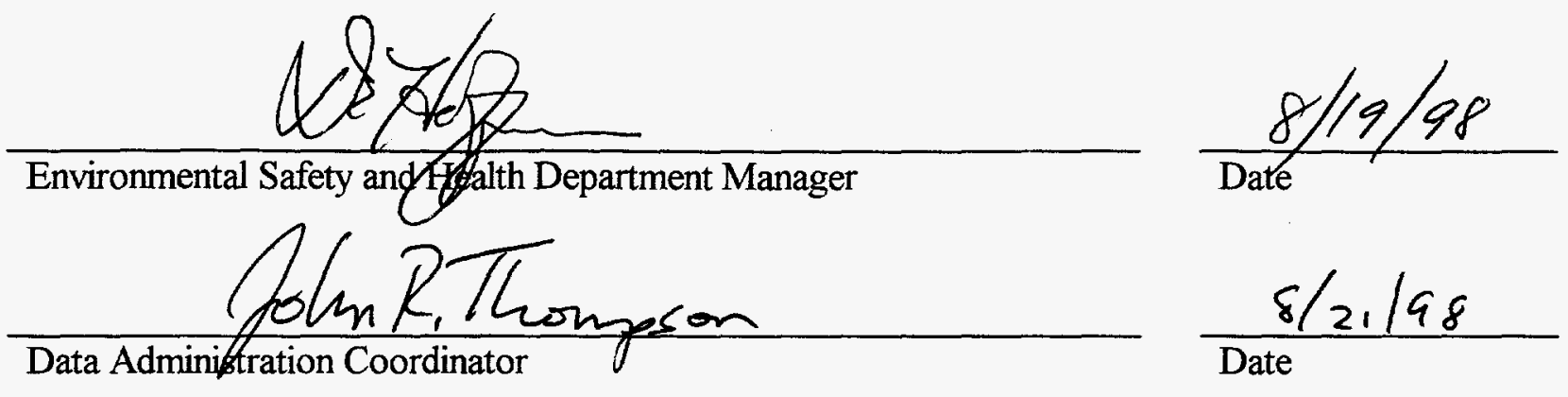

Orion cate

Project Quality Manager

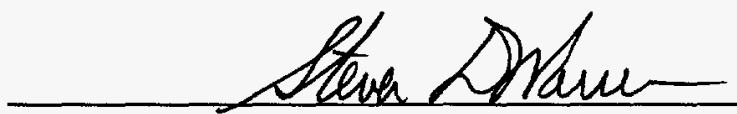

Deputy Project Director

$\frac{03 / 24 / 98}{\text { Date }}$

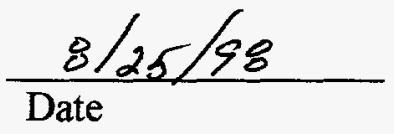

m:lusersljoanneldocumentlaser97lapr730.doc 


\section{DISCLAIMER}

This report was prepared as an account of work sponsored by an agency of the United States Government. Neither the United States Government nor any agency thereof, nor any of their employees, make any warranty, express or implied, or assumes any legal liability or responsibility for the accuracy, completeness, or usefulness of any information, apparatus, product, or process disclosed, or represents that its use would not infringe privately owned rights. Reference herein to any specific commercial product, process, or service by trade name, trademark, manufacturer, or otherwise does not necessarily constitute or imply its endorsement, recommendation, or favoring by the United States Government or any agency thereof. The views and opinions of authors expressed herein do not necessarily state or reflect those of the United States Government or any agency thereof. 


\section{DISCLAIMER}

Portions of this document may be illegible in electronic image products. Images are produced from the best available original document. 
DOE/OR/21548-730

Weldon Spring Site Remedial Action Project

Weldon Spring Site Environmental Report for Calendar Year 1997

Revision 0

August 1998

Prepared by

MK-FERGUSON COMPANY

and

JACOBS ENGINEERING GROUP

7295 Highway 94 South

St. Charles, Missouri 63304

for the

U.S. DEPARTMENT OF ENERGY

Oak Ridge Operations Office

Under Contract DE-AC05-86OR21548 
Printed in the United States of America. Available from the National Technical Information Service, NTIS, U.S. Department of Commerce, 5285 Port Royal Road, Springfield, Virginia 22161 .

NTIS Price Codes - Printed Copy: A07

Microfiche: A01

About the Front Cover...

Top Left: Aerial view of the Chemical Stabilization and Solidification Plant taken Spring 1998.

Top Right: After contaminated material is excavated, samples of the remaining soil are taken to confirm that remediation efforts were successful.

Center: $\quad$ Aerial view of the WSSRAP Disposal Cell taken Spring 1998.

Bottom Right: Workers install geosynthetic clay liner on the disposal cell floor subgrade.

Bottom Left: Water is sampled during treatment at the site water treatment plant. 


\section{EXECUTIVE SUMMARY}

This Weldon Spring Site Environmental Report for Calendar Year 1997 has been prepared to provide information about the public safety and environmental protection programs conducted by the Weldon Spring Site Remedial Action Project (WSSRAP). The Weldon Spring site is located in southern St. Charles County, Missouri, approximately $48 \mathrm{~km}(30 \mathrm{mi})$ west of St. Louis. The site consists of two main areas, the Weldon Spring Chemical Plant and raffinate pits and the Weldon Spring Quarry. The chemical plant, raffinate pits, and quarry are located on Missouri State Route 94, southwest of U.S. Route 40/61.

The objectives of the Site Environmental Report are to present a summary of data from the environmental monitoring program, to characterize trends and environmental conditions at the site, and to confirm compliance with environmental and health protection standards and requirements. The report also presents the status of remedial activities and the results of monitoring these activities to assess their impacts on the public and environment.

This report includes monitoring data from routine radiological and nonradiological sampling activities. These data include estimates of dose to the public from the Weldon Spring site, estimates of effluent releases, and trends in groundwater contaminant levels. Additionally, applicable compliance requirements, quality assurance programs, and special studies conducted in 1997 to support environmental protection programs are discussed.

Dose estimates presented in this report are based on hypothetical exposure scenarios for public use of areas near the site. In addition, release estimates have been calculated on the basis of 1997 National Pollutant Discharge Elimination System (NPDES) and air monitoring data. Effluent discharges from the site under routine NPDES and National Emission Standards for Hazardous Air Pollutants (NESHAPs) monitoring were below permitted levels for radionuclides.

\section{MONITORING OVERVIEW}

WSSRAP environmental management programs are designed to ensure that releases from the site are at levels demonstrably and consistently "as low as reasonably achievable" (ALARA). The ALARA principle drives the work activities related to site remediation and contaminant cleanup programs under U.S. Environmental Protection Agency (EPA) enforcement of the Comprehensive Environmental Response, Compensation and Liability Act (CERCLA).

Effluent and environmental monitoring programs provide early detection of contaminants, assessment of potential impacts to the environment, and data needed to implement the ALARA strategy. Routine monitoring also demonstrates compliance with applicable State and Federal permits and regulations. 


\section{REGULATORY COMPLIANCE}

The Weldon Spring site is listed on the National Priorities List (NPL) and is governed by the CERCLA. Under the CERCLA, the WSSRAP is subject to meeting or exceeding applicable or relevant and appropriate requirements of Federal, State, and local laws. Primary regulations include the Resource Conservation and Recovery Act (RCRA), Clean Water Act (CWA), Clean Air Act (CAA), Toxic Substances Control Act (TSCA), the National Historic Preservation Act (NHPA) and, because the U.S. Department of Energy (DOE) is the lead agency for the site, the incorporation of the National Environmental Policy Act (NEPA) values into CERCLA documents as outlined in the Secretarial Policy statement on NEPA.

The Weldon Spring Quarry Bulk Wastes Operable Unit was officially completed in April 1997 with the submission of the Quarry Bulk Waste Excavation Remedial Action Report to the U.S. Environmental Protection Agency, Region VII.

An Organic Waste Treatability Study using solvated electron technology has been initiated. Wastes to be treated include polychlorinated biphenyls (PCBs) and other chlorinated organic compounds as well as non-chlorinated aromatic unsaturated hydrocarbons.

Ten containers of waste were transferred to the K-25 incinerator in Oak Ridge, Tennessee for treatment.

Five NPDES permit exceedances occurred in 1997. Twice, site storm water contained levels of settleable solids greater than the limit allowed by the site NPDES permit. Additionally, the permitted limit for biochemical oxygen demand (BOD) in sewage treatment plant effluent was exceeded three times during one reporting period.

\section{MONITORING SUMMARY}

Environmental monitoring data showed that dose estimates were below the $U$. S. Department of Energy guideline of 100 mrem $(1 \mathrm{mSv})$ annual total effective dose equivalent for all exposure pathways. NESHAPs air monitoring results for radioactive air particulates showed that dose estimates were all well below the NESHAPs standard of 10 mrem $(0.1 \mathrm{mSv})$ per year. The $1997 \mathrm{Rn}-220$ total release estimate was $42 \mathrm{Ci}(1.6 \mathrm{E} 12 \mathrm{~Bq})$. The total release of $\mathrm{Rn}-222$ during the year was comparable to background; therefore, no estimate of dose was made.

Release estimates for total uranium in water (which include storm water and water from the treatment plants) decreased from the 1996 release estimate of $0.026 \mathrm{Ci}(9.6 \mathrm{E} 8 \mathrm{~Bq})$ to $0.015 \mathrm{Ci}(6.7 \mathrm{E} 8 \mathrm{~Bq})$ in 1997 ; however, the annual release of total uranium for 1997 is a $95 \%$ reduction of the 1987 annual estimate. Effluent releases were below the DOE derived concentration guide level of $600 \mathrm{pCi} / \mathrm{l}$. Data from groundwater and surface water monitoring indicated no measurable impact on drinking water sources from Weldon Spring site contaminants.

DOE/OR/21548-730, Rev. 0 


\section{Dose Estimates}

In 1997, the maximum total effective dose equivalent to a hypothetical individual employed full-time at the Missouri Highway Transportation Department (MHTD) facility was 2.5 mrem $(0.025 \mathrm{mSv})$. This scenario assumed an individual working outside the maintenance facility 2,000 hours/year. The maximum total effective dose equivalent to a hypothetical individual at the boundary of the quarry was $0.001 \mathrm{mrem}(1.0 \mathrm{E}-5 \mathrm{mSv})$. This scenario assumed an individual walking along the southeastern perimeter of the quarry 5 hours/year. The total effective dose equivalent to a maximally exposed individual at the vicinity properties from consumption of water was $0.46 \mathrm{mrem}(4.6 \mathrm{E}-3 \mathrm{mSv})$. This scenario assumed an individual walking past Burgermeister Spring once per week and drinking one cup $(0.237 \mathrm{l})$ of spring water each visit. These estimates are below the DOE guideline of $100 \mathrm{mrem}(1 \mathrm{mSv})$ annual total effective dose equivalent for all exposure pathways. By comparison, the annual total effective dose equivalent in the United States due to naturally occurring sources of radioactivity is approximately $300 \mathrm{mrem}(3 \mathrm{mSv})$.

The collective population dose equivalent for the population assumed to frequent the Busch Memorial Conservation Area and employees of the MHTD facility and WSSRAP administration building was 0.13 person-rem ( 0.0013 person-Sv). The Busch Conservation Area estimate was based on an affected population of 160,000 persons assumed to have potential for exposure through ingestion of fish, water, and sediments. The MHTD estimate was based on a staff of nine full-time employees exposed to above-background levels of gamma radiation. The WSSRAP administration building estimate was based on a staff of 300 employees being exposed to elevated concentrations of radioactive airborne particulates (assumed to be total uranium).

\section{Air Monitoring}

During 1997, airborne releases from the Weldon Spring Chemical Plant area included $\mathrm{Rn}-220$ gas and progeny and radioactive airborne particulates. Radioactive airborne particulates were assumed to include $\mathrm{Ra}-226, \mathrm{Ra}-228$, Th-228, Th-230, Th-232, and total uranium.

The estimated off-site $\mathrm{Rn}-220$ release was $42 \mathrm{Ci}(1.5 \mathrm{E} 12 \mathrm{~Bq})$. Statistical analysis of integrated radon track etch data indicates that the concentrations at three perimeter and nine interior stations near the raffinate pits were greater than background levels. Statistical analysis of modified track etch detector data indicates one station at the quarry, three stations at the raffinate pits, and three stations along the chemical plant perimeter that exceeded background levels of $\mathrm{Rn}$-220. All track etch results were below the derived concentration guide (DCG) for Rn-222 and $\mathrm{Rn}-220$ of $3 \mathrm{pCi} / 1(0.11 \mathrm{~Bq})$.

The results of NESHAPs monitoring for radioactive particulates indicated that all doses to the public at critical receptor locations were, at the $95 \%$ confidence level, less than the NESHAPs standard of 10 mrem $(0.1 \mathrm{mSv})$ per year. Critical receptor locations included the Missouri Highway Maintenance Facility, Busch Memorial Conservation Area, Francis Howell High School 
and Annex, the WSSRAP administration building, the nearest quarry residence, and the Department of the Army Weldon Spring Training Area (Figure 6-1). Statistical analysis of NESHAPs monitoring results indicated that all stations were indistinguishable from background.

Environmental monitoring for asbestos was not performed during 1997 because no asbestos abatement work was conducted.

\section{NPDES Monitoring}

In 1997 , surface water runoff at the chemical plant transported uranium from the site through six major discharge routes that are identified in Section 7 of this report. Radionuclide release estimates were calculated on the basis of the activity of uranium. The estimate of uranium released to water was $7.39 \mathrm{E}-3 \mathrm{Ci}(2.7 \mathrm{E} 8 \mathrm{~Bq})(\mathrm{l} \mathrm{g})$ for $\mathrm{U}-234,0.001 \mathrm{Ci}(1.28 \mathrm{E} 9 \mathrm{~Bq})(0.16 \mathrm{~kg})$ for U-235, and 7.32E-3 Ci (2.7E8 Bq) (22 kg) for U-238. Section 11, Special Studies, provides additional details regarding release of uranium in surface water.

Annual average uranium concentrations decreased at storm water Outfalls NP-0002 and NP-0005. Decreases at both outfalls are attributed to partial or complete remediation of the watersheds during the year. The increase at Outfall NP-0003 is attributable to the storage of contaminated materials in Ash Pond and the active remediation upstream of the outfall. The average concentration increased slightly at the site water treatment plant and decreased slightly at the quarry water treatment plant. These changes are attributable to normal variations in plant operation.

The annual average uranium concentration decreased at storm water Outfall NP-0010. The decrease is attributable to the remediation of the North Dump area for the construction material staging area (CMSA) that was completed in 1996.

Missouri River sediment was monitored during 1997 in support of site and quarry water treatment plant operations. Sediment samples were taken from the river both up and downstream of the treatment plant discharges and analyzed for uranium. The sample results indicate that the treatment plant discharges have caused no increase in uranium concentrations in river sediment.

\section{Surface Water}

Surface water monitoring in 1997 indicated that contaminant concentrations were within historic ranges.

\section{Groundwater}

The groundwater monitoring program included extensive monitoring for radiological and chemical compounds. Radiological results for the St. Charles County well field remained within 
background levels. No detectable concentrations of the six nitroaromatic compounds of concern were found in groundwater monitoring wells south of the Femme Osage Slough, including the well field, which is near the quarry.

Environmental groundwater monitoring indicates that contamination is still present in the bedrock of the quarry rim and in the alluvial materials and bedrock north of the Femme Osage Slough. Some sample locations nearest the quarry show decreases in nitroaromatic compounds and radiological parameters. This is likely due to source (quarry bulk waste) removal.

At the chemical plant, the volatile organic compounds trichloroethane and dichloroethane were detected in groundwater in the vicinity of Raffinate Pits 3 and 4 . An investigation to determine the extent and sources of the volatile compound contamination has been ongoing since April 1996. Uranium, sulfate, nitrate, and nitroaromatic compounds in groundwater and springs remained near historic ranges. High concentrations of uranium typically occur in groundwater wells near Raffinate Pit 4 and at the southeast corner of the chemical plant. Contaminant transport continued to be primarily confined to the upper weathered zone of the bedrock aquifer at the plant; however, uranium concentrations in one unweathered zone location east of Raffinate Pit 3 increased during 1997.

\section{Biological}

The DOE has completed the first year of wetland monitoring at the DOE-funded mitigation wetland complex located on the August A. Busch Conservation Area. Monitoring of this wetland will continue through 1999. Preliminary results indicate that vegetation and soil characteristics at the site make it highly suitable for development of a viable wetland. 


\section{ABSTRACT}

This Site Environmental Report for Calendar Year 1997 describes the environmental monitoring programs at the Weldon Spring Site Remedial Action Project (WSSRAP). The objectives of these programs are to assess actual or potential exposure to contaminant effluents from the project area by providing public use scenarios and dose estimates, to demonstrate compliance with Federal and State permitted levels and regulations, and to summarize trends and/or changes in contaminant concentrations identified through environmental monitoring.

In 1997, the maximum total effective dose equivalent (TEDE) to a hypothetical individual who was employed full-time at the nearby Missouri Highway Transportation Department (MHTD) maintenance facility was $2.5 \mathrm{mrem}(0.025 \mathrm{mSv})$. The maximum TEDE to a hypothetical individual at the boundary of the Weldon Spring Quarry was 0.001 mrem (1.0E-5 mSv). The maximum TEDE to a hypothetical individual who frequents the Weldon Spring Vicinity Properties was 0.46 mrem $(4.6 \mathrm{E}-3 \mathrm{mSv})$. These estimates are below the U.S. Department of Energy requirement of $100 \mathrm{mrem}(1 \mathrm{mSv})$ annual total effective dose equivalent for all exposure pathways.

The combined collective population dose equivalent for the population assumed to frequent the Busch Memorial Conservation Area (160,000 individuals) and employees of the MHTD facility (nine individuals) and WSSRAP administration building (300 individuals) was 0.13 person-rem (1.3E-3 person-Sv). Results from radiological air monitoring for the National Emission Standards for Hazardous Air Pollutants (NESHAPs) program indicated that all estimated total effective dose equivalents were less than the U.S. Environmental Protection Agency (EPA) standard of $10 \mathrm{mrem}(0.1 \mathrm{mSv})$ per year.

Comprehensive monitoring indicated that emissions of radiological compounds in airborne and surface water discharges from the Weldon Spring site consisted primarily of Rn-220 gas, isotopes of thorium and radium, and natural uranium. Airborne $\mathrm{Rn}-220$ emissions were estimated to be $42 \mathrm{Ci}(1.6 \mathrm{E} 12 \mathrm{~Bq})$, while emissions from a combination of thorium; radium, and natural uranium isotopes to air and surface water were estimated to be $0.018 \mathrm{Ci}(6.7 \mathrm{E} 8 \mathrm{~Bq})$, for a total of $25,000 \mathrm{~g}(25 \mathrm{~kg})$. There was no measurable impact to any drinking water source.

Concentration limits are set for water pollutants in the National Pollutant Discharge Elimination System (NPDES) permits. Parameters were in compliance with the permit limits except on five occasions. Exceedences for settleable solids occurred at Outfall NP-0002 in February and August. There were also three exceedences of the BOD limit at NP-0006 (sewage treatment plant) during April. 


\section{TABLE OF CONTENTS}

SECTION

PAGE

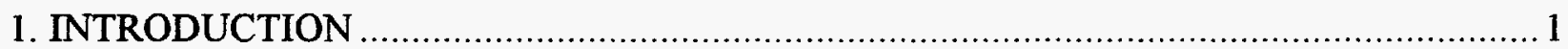

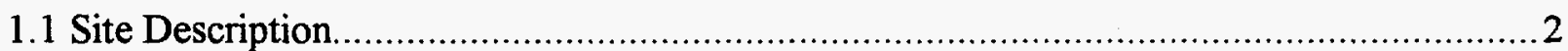

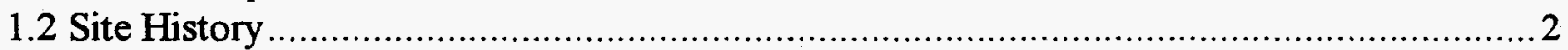

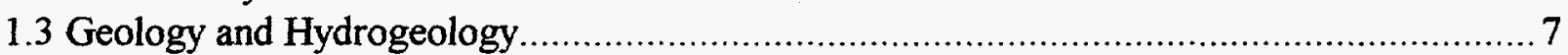

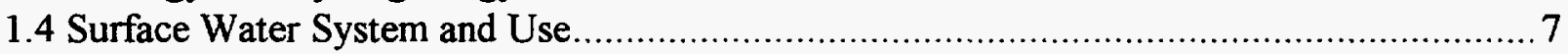

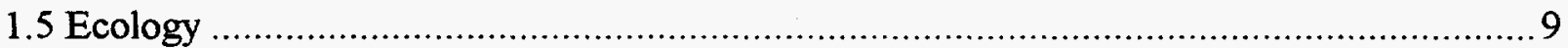

1.6 Climate

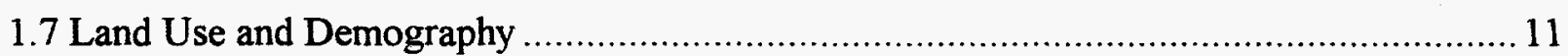

2. ENVIRONMENTAL PROTECTION/RESTORATION PROGRAM OVERVIEW ............ 14

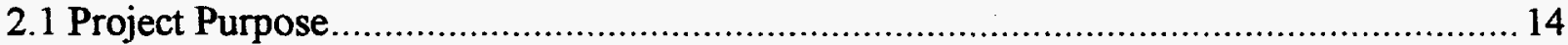

2.2 Project Management ........................................................................................ 14

2.3 Environmental Monitoring Program Overview .................................................. 14

2.4 Project Accomplishments in 1997 ................................................................ 15

2.4.1 Weldon Spring Chemical Plant Operable Unit.................................................. 16

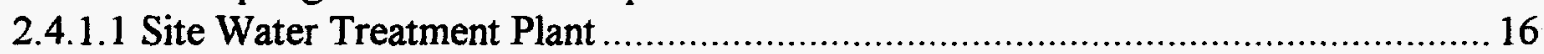

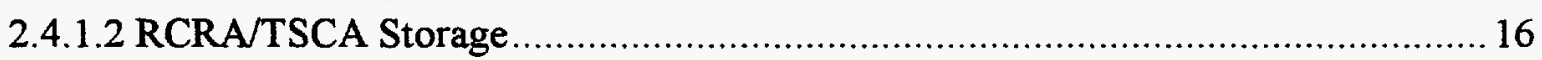

2.4.1.3 Disposal Cell .......................................................................................... 16

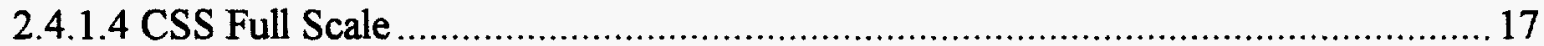

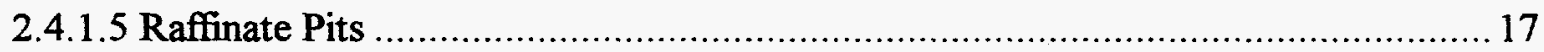

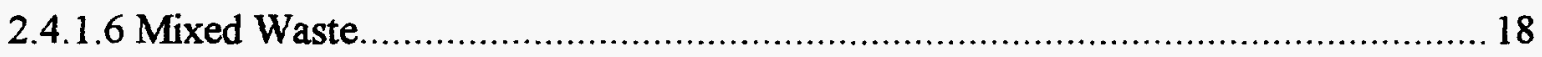

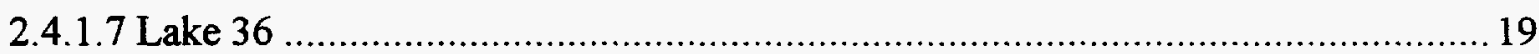

2.4.2 Weldon Spring Quarry Bulk Wastes Operable Unit ........................................ 19

2.4.2.1 Quarry Water Treatment Plant ................................................................... 19

2.4.3 Weldon Spring Quarry Residuals Operable Unit ........................................... 19

2.4.4 Weldon Spring Groundwater Operable Unit ..................................................... 20

2.5 Incident Reporting - Environmental Occurrences in 1997 ....................................... 21

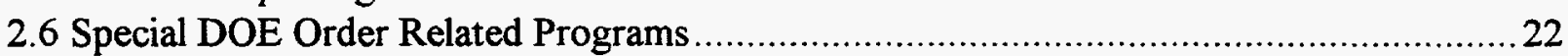

2.6.1 Groundwater Protection Management Program ............................................. 22

2.6.2 Meteorological Monitoring Program .......................................................... 22

2.6.3 Surface Water Management Program ............................................................... 23

2.6.4 Radiation Protection Program ...................................................................... 23

2.6.5 Waste Management Program..................................................................... 23

2.6.6 Waste Minimization/Pollution Prevention Program........................................... 24

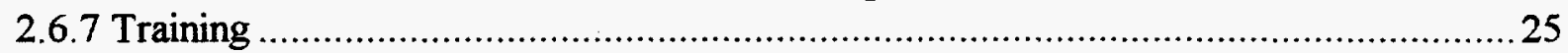

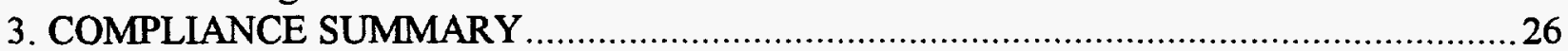




\section{TABLE OF CONTENTS}

SECTION

PAGE

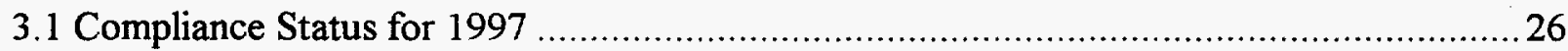

3.1.1 Federal and State Regulatory Compliance ................................................. 26

3.1.2 DOE Order Compliance .............................................................................. 30

3.1.2.1 DOE Order 5400.5, Radiation Protection of the Public and the Environment....... 30

3.1.2.2 DOE Order 5820.2A, Radioactive Waste Management .................................. 30

3.1.2.3 DOE Order 5400.1, General Environmental Protection Program ....................... 31

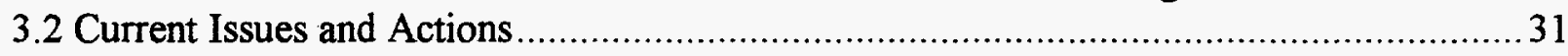

3.2.1 Current Issues .................................................................................. 31

3.2.1.1 National Emission Standards for Hazardous Air Pollutants Compliance ............... 31

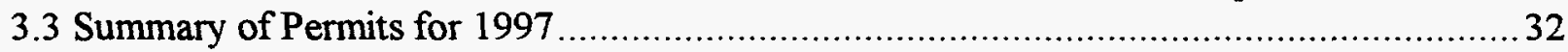

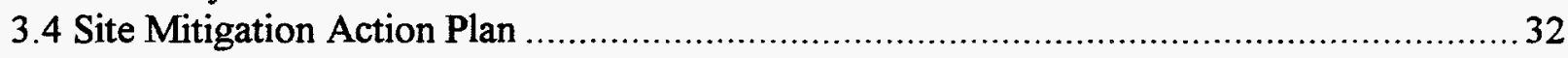

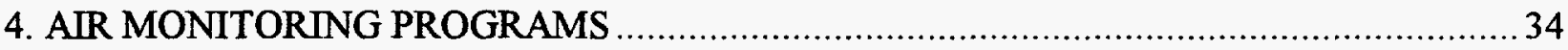

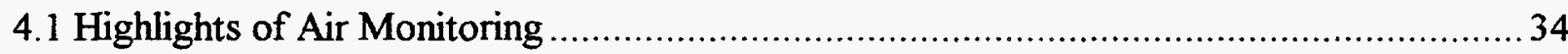

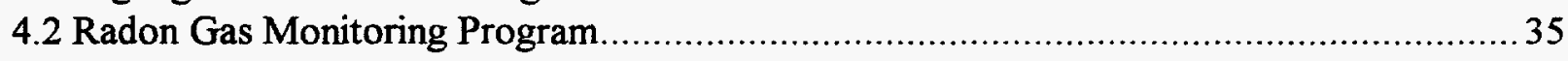

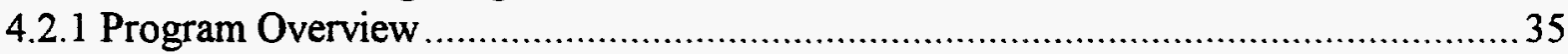

4.2.2 Applicable Standards......................................................................... 40

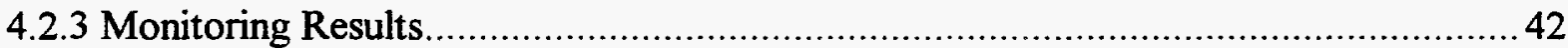

4.2.4 Data Analysis ................................................................................... 47

4.2.4.1 Chemical Plant and Raffinate Pits ............................................................. 50

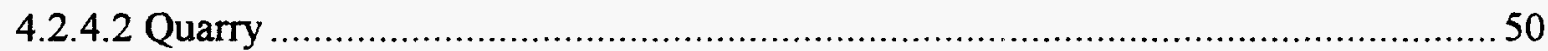

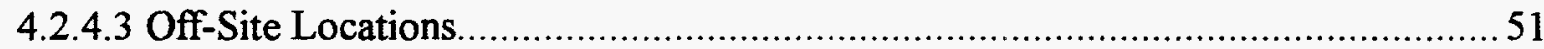

4.2.4.4 Five-Year Trend Analysis of Integrated Radon Gas ...................................... 51

4.3 Gamma Radiation Monitoring ................................................................... 51

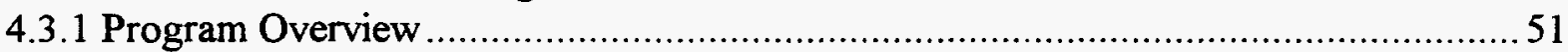

4.3.2 Applicable Standards....................................................................... 53

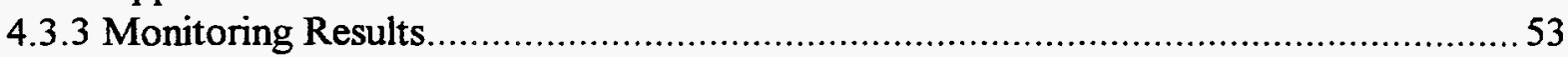

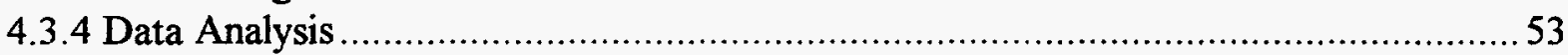

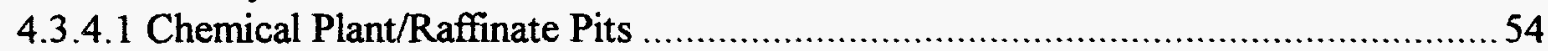

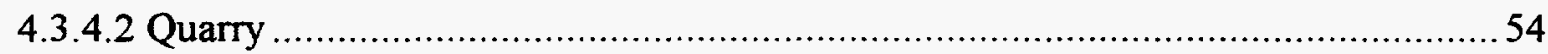

4.3.4.3 Off-Site Locations............................................................................... 55

4.3.4.4 Five-Year Trend Analysis of TLDs.......................................................... 55

4.4 Radioactive Air Particulate Monitoring ..................................................... 55

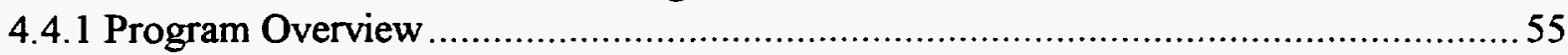

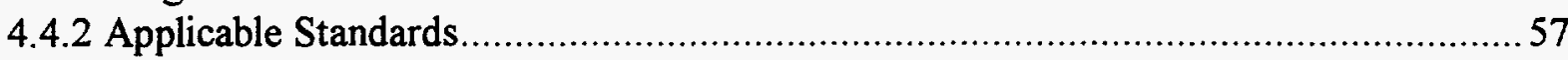

4.4.3 Monitoring Results.................................................................................. 57 


\section{TABLE OF CONTENTS}

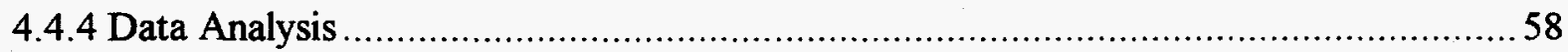

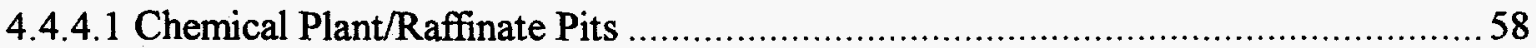

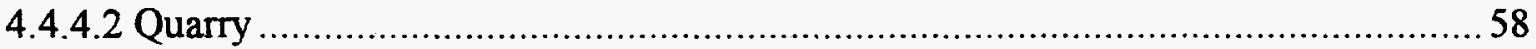

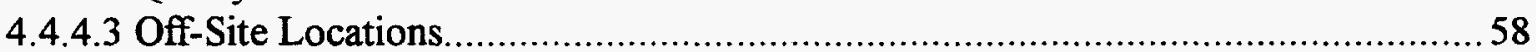

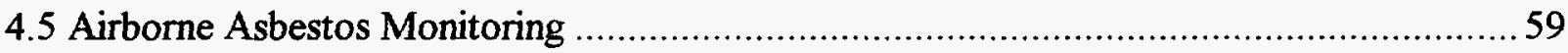

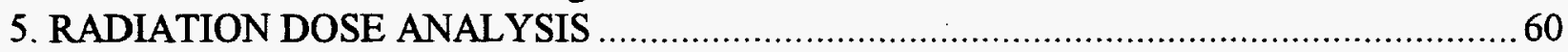

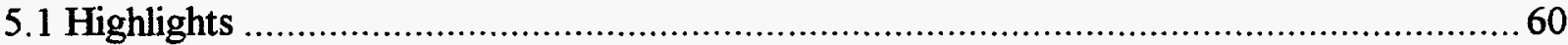

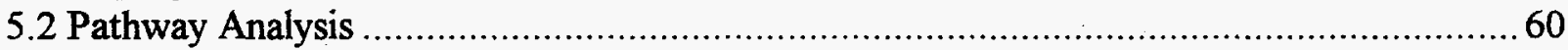

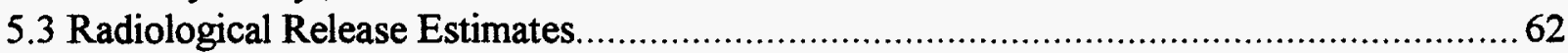

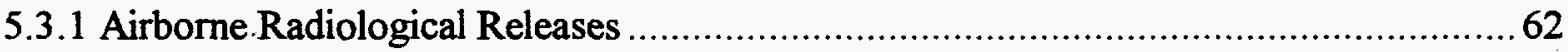

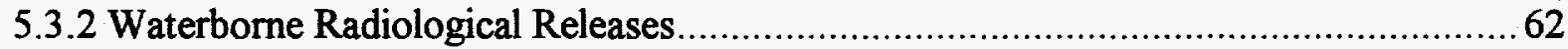

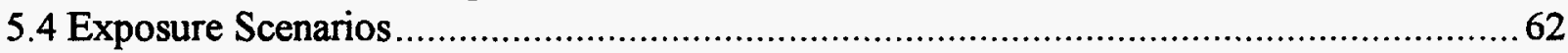

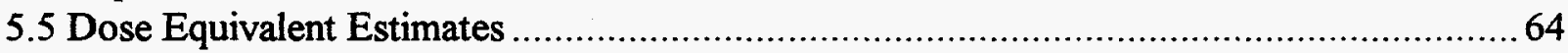

5.5.1 Radiation Dose Equivalent From the Chemical Plant and Raffinate Pits to a Hypothetical Maximally Exposed Individual ..........................................................6. 67 5.5.2 Radiation Dose From the Weldon Spring Quarry to a Hypothetical Maximally Exposed

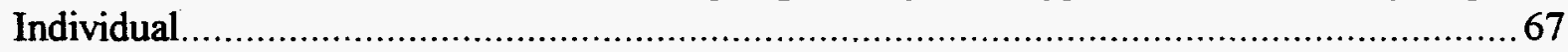
5.5.3 Radiation Dose From Vicinity Properties to a Hypothetical Maximally Exposed

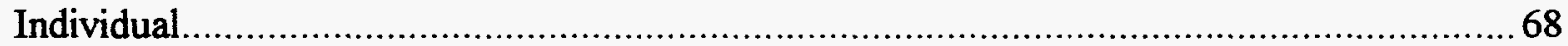

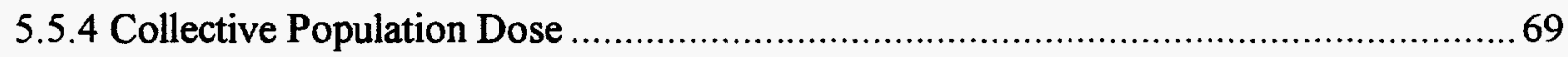

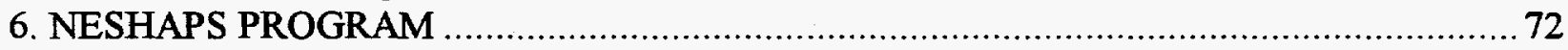

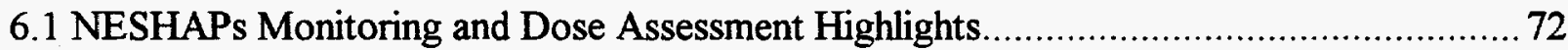

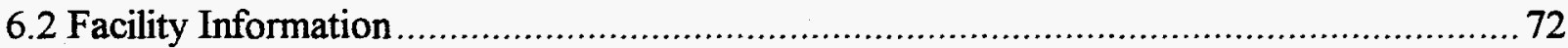

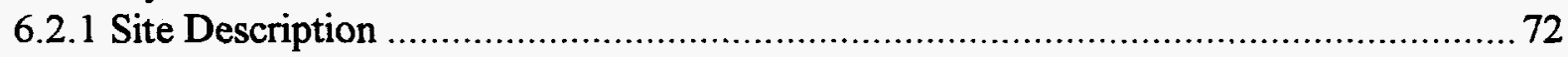

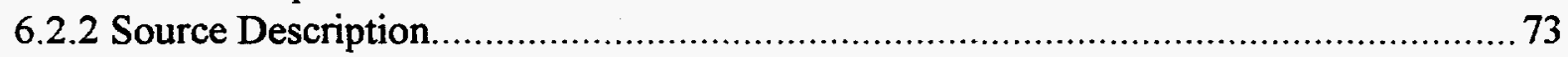

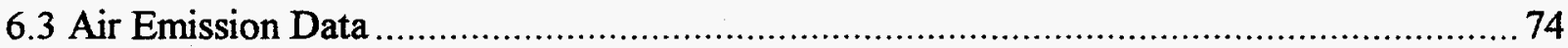

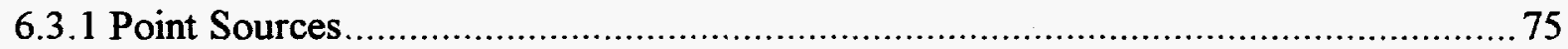

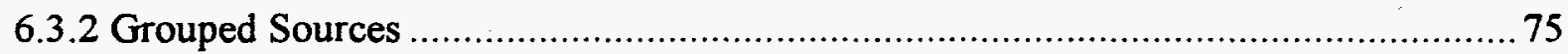

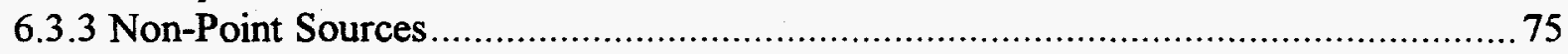

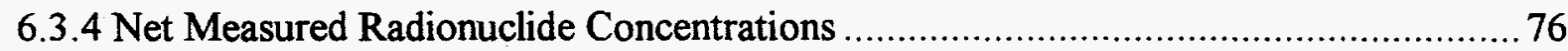

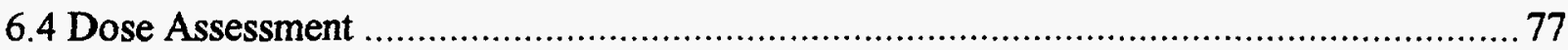

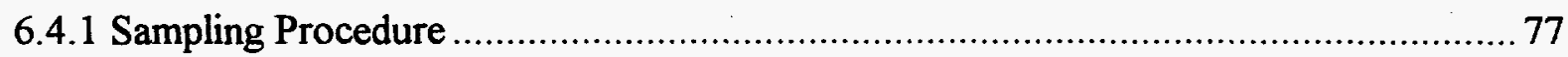

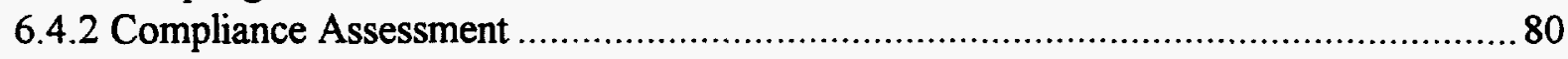

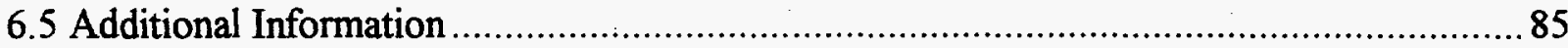

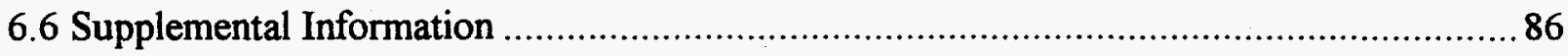




\section{TABLE OF CONTENTS}

6.6.1 Collective Population Dose and Airborne Release Estimates................................ 86

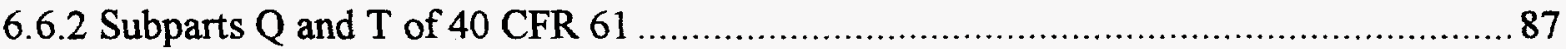

6.6.3 Radon Emissions from WSSRAP Non-Storage Sources .................................. 87

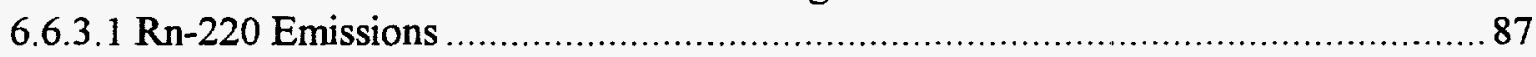

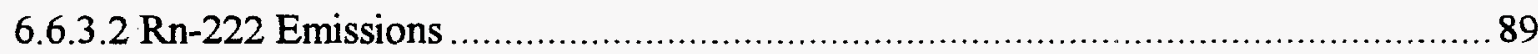

6.6.4 Effluent Monitoring Requirements.............................................................. 89

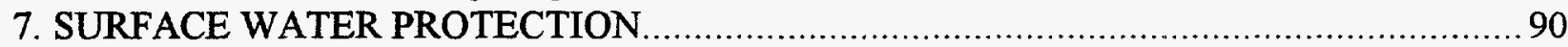

7.1 Highlights of the Surface Water Program .......................................................... 90

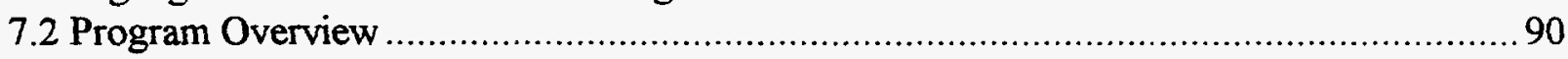

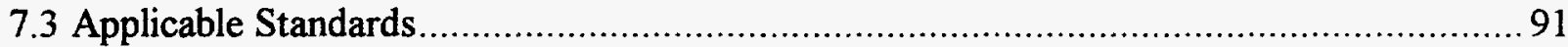

7.4 Hydrology Description of the Site and Quarry ...................................................... 94

7.4.1 Weldon Spring Chemical Plant and Weldon Spring Raffinate Pits .......................... 94

7.4.2 Weldon Spring Quarry ....................................................................... 97

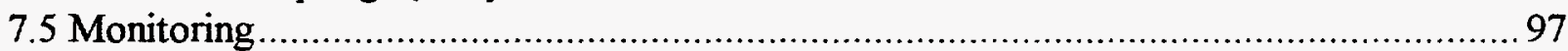

7.5.1 National Pollutant Discharge Elimination System Monitoring ............................. 97

7.5.2 Surface Water Monitoring ..................................................................... 99

7.5.2.1 Weldon Spring Chemical Plant and Weldon Spring Raffinate Pits .................... 99

7.5.2.2 Weldon Spring Quarry ..................................................................... 99

7.6 Monitoring Results.......................................................................... 100

7.6.1 National Pollutant Discharge Elimination System Program Monitoring Results........ 100

7.6.1.1 Radiochemical Analysis............................................................... 100

7.6.1.2 Physical and Chemical Results.......................................................... 106

7.6.1.2.1 Chemical Plant Storm Water ............................................................. 106

7.6.1.2.2 Administration Building Sewage Treatment Plant ................................. 107

7.6.1.2.3 Site and Quarry Water Treatment Plant Physical and Chemical Parameters... 108

7.6.1.2.4 Hydrostatic Test Water Results........................................................... 109

7.6.1.2.5 Borrow Area and Haul Road Land Disturbance Results ........................... 109

7.6.2 Surface Water Monitoring Results.......................................................... 110

7.6.2.1 Weldon Spring Chemical Plant and Weldon Spring Raffinate Pits ................... 110

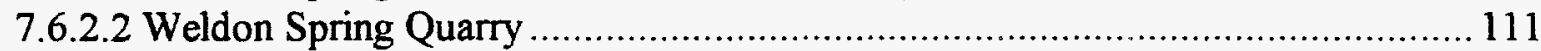

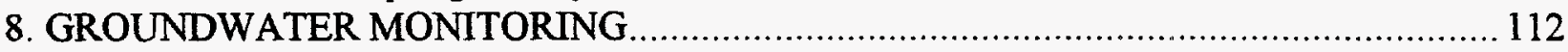

8.1 Highlights of the Groundwater Monitoring Program .......................................... 112

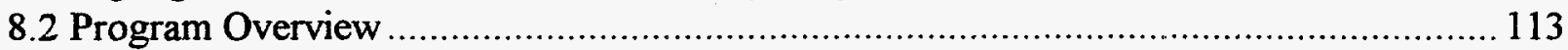

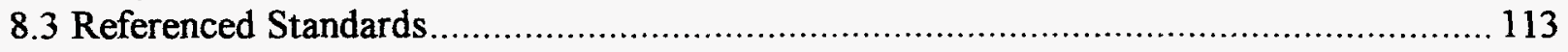

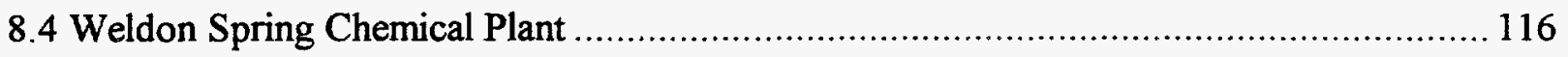




\section{TABLE OF CONTENTS}

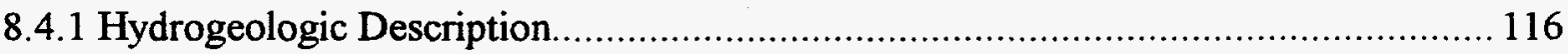

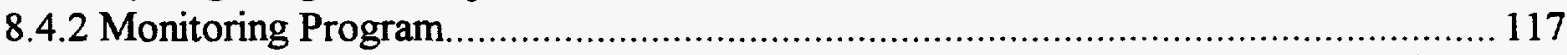

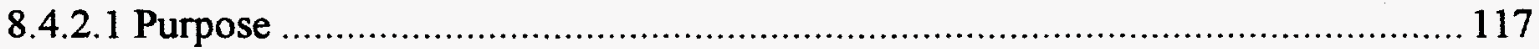

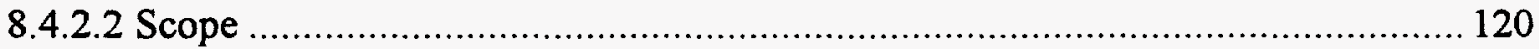

8.4.3 Chemical Plant and Raffinate Pit Monitoring Results .................................... 121

8.4.3.1 Groundwater Monitoring Wells...................................................... 121

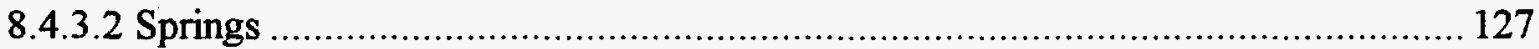

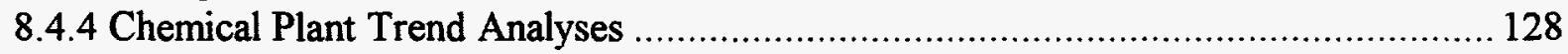

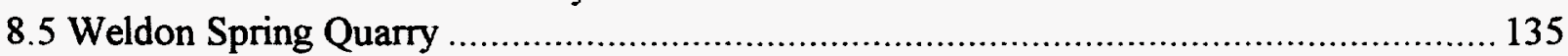

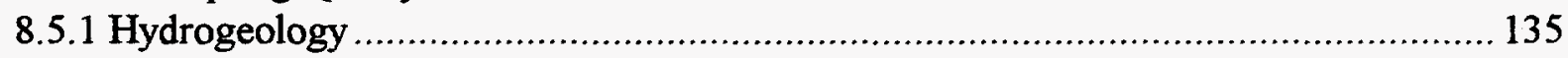

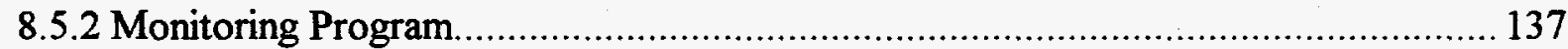

8.5.3 Weldon Spring Quarry Monitoring Results................................................. 139

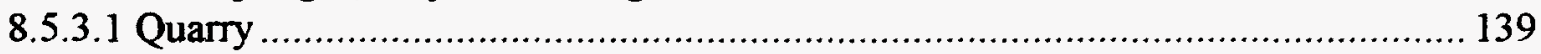

8.5.3.2 St. Charles County Well Field ............................................................... 142

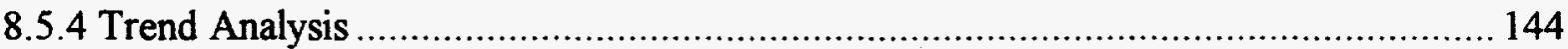

8.6 Waste Treatment Facilities ........................................................................... 149

8.6.1 Monitoring Program.................................................................................. 149

8.6.2 Site Water Treatment Plant and Temporary Storage Area Monitoring Results ......... 150

8.6.3 Quarry Water Treatment Plant Monitoring Results ........................................ 153

8.6.4 Disposal Cell Groundwater Monitoring ...................................................... 158

9. BIOLOGICAL MONITORING PROGRAM ..................................................... 159

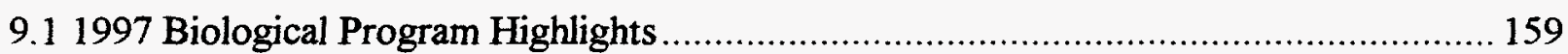

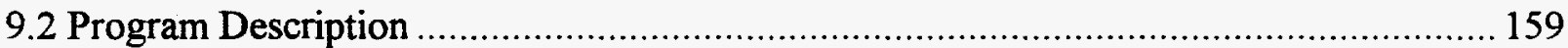

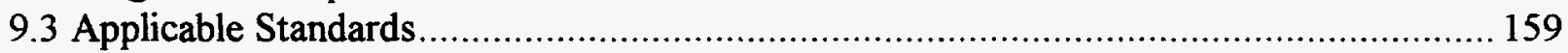

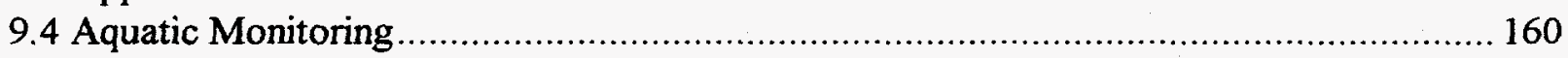

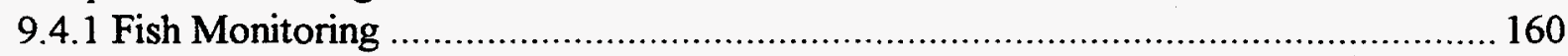

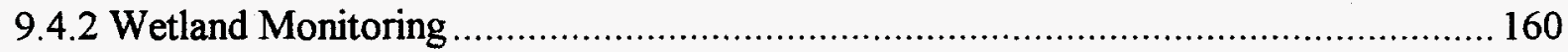

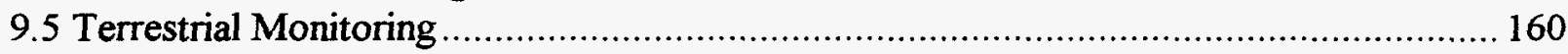

10. ENVIRONMENTAL QUALITY ASSURANCE PROGRAM INFORMATION ............. 162

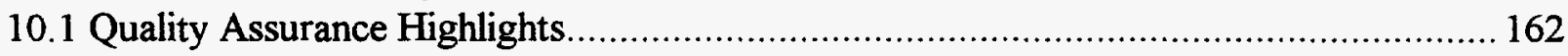

10.2 Program Overview ............................................................................. 162

10.2.1 Quality Assurance Program ................................................................. 162

10.2.2 Environmental Quality Assurance Project Plan ........................................... 162

10.2.3 Sample Management Guide .................................................................... 163

10.2.4 Environmental Monitoring and Quality Assurance Standard Operating Procedures . 163 


\section{TABLE OF CONTENTS}

SECTION

$\underline{\text { PAGE }}$

10.2.5 Evaluation and Presentation of Data ...................................................... 163

10.2.6 Independent Assessments and Appraisals.............................................. 164

10.2.7 Subcontracted Off-Site Laboratories Programs........................................... 164

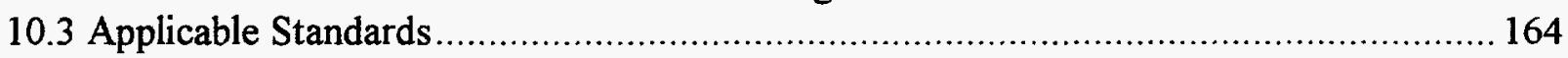

10.3.1 Analytical and Field Measurement Methodologies ....................................... 164

10.3.2 Quality Control Samples.................................................................... 165

10.3.3 Accuracy, Precision, and Completeness .................................................. 165

10.3.4 Preservation and Security of Documents and Records ...................................... 165

10.4 Quality Assurance Sample Results ......................................................... 165

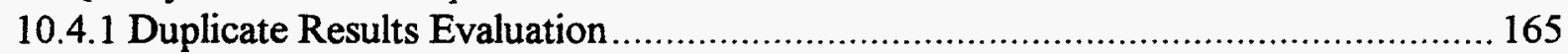

10.4.2 Blank Sample Results Evaluation ..................................................... 167

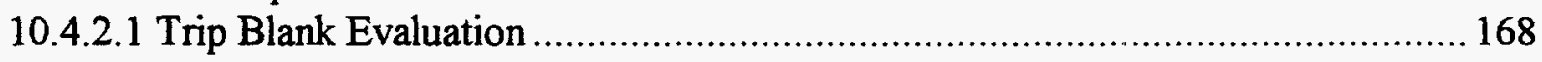

10.4.2.2 Field Blank Evaluation .................................................................... 168

10.4.2.3 Equipment and Bailer Blank Evaluation.............................................. 169

10.4.2.4 Distilled Water Blank Evaluation........................................................... 170

10.51997 Data Validation Program Summary ....................................................... 171

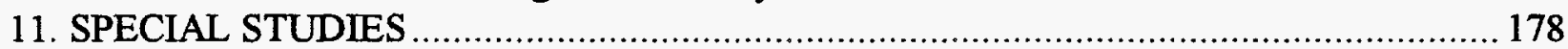

11.1 Off-Site Migration of Uranium in Storm Water ............................................. 178

11.2 Baseline Monitoring at NPDES Outfalls NP-0002, NP-0003, and NP-0005 .............. 185

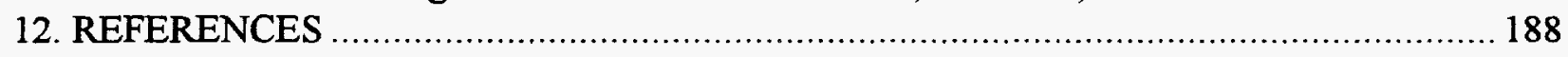

\section{APPENDIXES}

A Unpublished Documents

B Assumptions and Scenarios for Dose Calculations

C Distribution List 


\section{LIST OF FIGURES}

Figure 1-1 Location of the Weldon Spring Site 3

Figure 1-2 Weldon Spring Chemical Plant and Raffinate Pit Areas ...................................... 4

Figure 1-3 Weldon Spring Quarry Area ..................................................................... 5

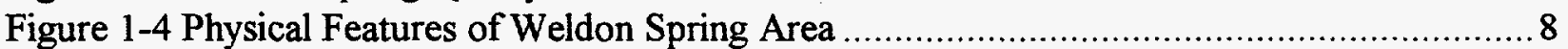

Figure 1-5 Wind Rose for Weldon Spring Meteorological Station Annual 1997 .................... 13

Figure 4-1 Radon and Air Particulate Monitoring Locations at the Chemical Plant Area ........... 36

Figure 4-2 Air Monitoring Locations at the WSQ Area .............................................. 37

Figure 4-3 Off-Site Air Monitoring Locations................................................................ 38

Figure 4-4 Background Air Monitoring Station .......................................................... 39

Figure 4-5 Electret Monitoring Locations at the Weldon Spring Raffinate Pits Area ................41

Figure 4-6 Radon Track Etch Detector 5-Year Trends .................................................. 52

Figure 4-7 Environmental TLD 5 Year Trends ............................................... 56

Figure 6-1 NESHAPS Critical Receptor Monitoring Locations......................................... 78

Figure 7-1 Surface Water and NPDES Monitoring Locations at the Weldon Spring Chemical

Plant and Raffinate Pits ................................................................................ 95

Figure 7-2 NPDES Surface Water Sampling Locations at the Weldon Spring Chemical Plant ....96

Figure 7-3 Surface Water and NPDES Monitoring Locations at the Weldon Spring Quarry ...... 98

Figure 8-1 Generalized Stratigraphy and Hydrostratigraphy of the Weldon Spring Area.......... 114

Figure 8-2 Groundwater Monitoring Locations at the Weldon Spring Chemical Plant and

Raffinate Pits Area ............................................................................ 118

Figure 8-3 Spring Monitoring Locations in the Weldon Spring Site Area ........................... 119

Figure 8-4 Groundwater Monitoring Locations at the Weldon Spring Quarry and St. Charles

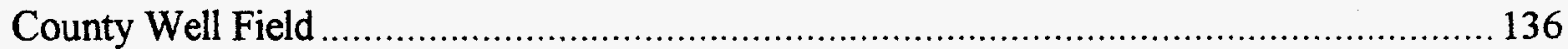

Figure 9-1 Fish Sampling Locations...................................................................... 161

Figure 11-1 Total Annual Uranium Discharged at Storm Water Outfall NP-0002................ 179

Figure 11-2 Total Annual Uranium Discharged at Storm Water Outfall NP-0003................. 180

Figure 11-3 Total Annual Uranium Discharged at Storm Water Outfall NP-0005.................. 181

Figure 11-4 Kilograms of Uranium Discharged Per Inch of Precipitation .......................... 182 


\section{LIST OF TABLES}

SECTION

PAGE

Table 1-1 Monthly Meteorological Monitoring Results for 1997 ......................................... 12

Table 2-1 Environmental Occurrences CY 1997 ......................................................... 21

Table 3-1 Summary of WSSRAP NPDES and Construction Permits ..................................... 32

Table 4-1 1997 Track Etch Integrated Radon Results ${ }^{(a)}$.................................................. 43

Table 4-2 1997 Thoron Concentrations as Determined Using Paired F-type and M-type Track Etch Detectors $^{(a)}$ .45

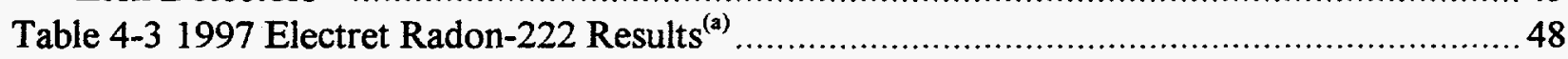

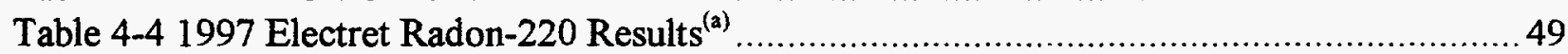

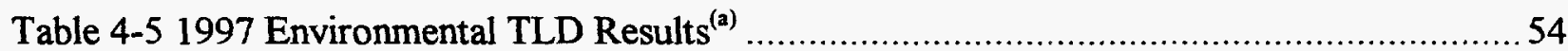

Table 4-6 1997 Radioactive Air Particulate Gross Alpha Results ......................................... 57

Table 5-1 Complete Radiological Exposure Pathways for the Weldon Spring Site ..................61

Table 5-2 Radionuclide Emissions to the Environment.................................................63

Table 5-3 Exposure Scenarios for Weldon Spring Site Radiological Dose Estimates ................65

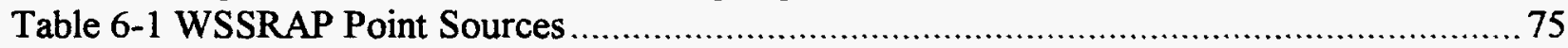

Table 6-2 Net Concentrations and Comparison........................................................ 77

Table 6-3 Exposure Scenarios and NESHAPs Dose Estimates for 1997.............................. 79

Table 6-4 NESHAPs Isotopic Air Monitoring Results with Effective Dose Equivalent Contributions, 1997

Table 7-1 Weldon Spring Chemical Plant Storm and Sanitary Water (NPDES Permit MO-0107701) Monitoring Requirements

Table 7-2 Treated Effluent Parameter Limits and Monitoring Requirements for Quarry Water

Treatment Plant (NPDES Permit MO-0108987) and Site Water Treatment Plant (NPDES

Permit MO-0107701)*

Table 7-3 1997 Annual Average NPDES Results for the Weldon Spring Chemical Plant Storm Water Outfalls

Table 7-4 Site and Quarry Water Treatment Plant Annual Averages for Radium and Thorium $(\mathrm{pCi} / \mathrm{l})$... 102

Table 7-5 1997 Estimated Annual Release of Natural Uranium from NPDES Outfalls............. 103

Table 7-6 Six-Year Annual Average Uranium Concentrations at NPDES Outfalls.................. 104

Table 7-7 MSA, Ash Pond and Frog Pond - 1997 Annual Average Radiological Concentrations $(\mathrm{pCi} / 1)$ 105

Table 7-8 Ash and MSA Pond - 1997 Annual Average Chemical Concentrations $(\mu \mathrm{g} / \mathrm{l})$. 107

Table 7-9 NP-0006, Sewage Treatment Plant Outfall, Monthly Averages of Permitted 


\section{LIST OF TABLES}

\section{SECTION}

$\underline{\text { PAGE }}$

Table 7-10 1997 Whole Effluent Toxicity Test Results for the Site and Quarry Water Treatment Plants*... 108

Table 7-11 Borrow Area Settleable Solids (ml/l/hr)

Table 7-12 Annual Averages for Total Uranium (pCi/l) Concentrations at Weldon Spring Chemical.

Table 7-13 Annual Averages for Total Uranium (pCi/l) at Weldon Spring Quarry Surface Water.

Table 8-1 Referenced Federal and State Water Standards.

Table 8-2 Derived Concentration Guidelines for Discharge Waters.

Table 8-3 Annual Total Uranium Activities ( $\mathrm{pCi} / \mathrm{l}$ ) Above Background at the Weldon Spring Chemical Plant

Table 8-4 Annual Radiological Isotope Activities (pCi/l) at the Weldon Spring Chemical Plant 122

Table 8-5 Annual Values of Nitrate (mg/l) Levels Exceeding Drinking Water Quality Standard at the Weldon Spring Chemical Plant

Table 8-6 Annual Values of Sulfate $(\mathrm{mg} / \mathrm{l})$ Above Background at the Weldon Spring Chemical Plant

Table 8-7 Annual 1997 Averages for Monitoring Locations with at Least One Detectable Concentration of Nitroaromatic Compounds $(\mu \mathrm{g} / \mathrm{l})$ at the Weldon Spring Chemical Plant.. 124

Table 8-8 1997 TCE and DCE Analytical Results Summary 125

Table 8-9 Chemical Plant Groundwater Wells Nitroaromatics Trend Analysis Summary .....

Table 8-10 Chemical Plant Groundwater Wells Total Uranium Trend Analysis Summary........ 131

Table 8-11 Chemical Plant Groundwater Wells Nitrate Trend Analysis Summary.................. 132

Table 8-12 Mean Background Values for Quarry Groundwater Monitoring Locations............ 138

Table 8-13 Annual Averages for Total Uranium (pCi/l) Above Average Background at the Weldon Spring Quarry

Table 8-14 Isotopic Radionuclide (pCi/l) Concentration Annual Averages That Exceeded Two Standard Deviations (Upper 95\% Confidence Interval) of Mean Background at the Weldon Spring Quarry

Table 8-15 Annual Averages for Detectable Concentrations of Nitroaromatic Compounds ( $\mu \mathrm{g} / 1$ ) at the Weldon Spring Quarry.

Table 8-16 Annual Averages for Sulfate (mg/1) Above Average Background at the Weldon Spring Quarry.....

Table 8-17 Summary of Annual Averages of Radiochemical Parameters (pCi/l) for the St. Charles County Well Field 


\section{LIST OF TABLES}

SECTION

PAGE

Table 8-18 Annual Averages for Sulfate (mg/1), Arsenic $(\mu \mathrm{g} / 1)$, and Barium $(\mu \mathrm{g} / 1)$ in the St. Charles County Well Field 143

Table 8-19 Quarry Groundwater Wells Nitroaromatics Trend Analysis Summary..... 145

Table 8-20 Quarry Groundwater Wells-Total Uranium Trend Analysis Summary..... 147

Table 8-21 Quarry Groundwater Wells Sulfate Trend Analysis Summary... 148

Table 8-22 Baseline for the Detection Monitoring System at the Weldon Spring Site Water

Treatment Plant and Temporary Storage Area. 152

Table 8-23 Summary of the 1997 Detection Monitoring Data for the Weldon Spring Site Water

Treatment Plant and Temporary Storage Area... 154

Table 8-24 Baseline for the Detection Monitoring System at the Weldon Spring Quarry Water

Treatment Plant 155

Table 8-25 Summary of the 1997 Detection Monitoring Data for the Weldon Spring Quarry

Water Treatment Plant 156

Table 10-1 QC Sample Description 166

Table 10-2 Summary of Calculated Relative Percent Differences 167

Table 10-3 Summary of Field Blank Parameter Results 169

Table 10-4 Summary of Distilled Water Blank Parameter Results 170

Table 10-5 WSSRAP Validation Summary for Calendar Year 1997. 171

Table 10-6 WSSRAP Validation Summary for Calendar Year 1997. 172

Table 10-7 Laboratory Accuracy and Precision Summary for Calendar Year 1997 ................ 174

Table 11-1 Mass of Uranium Discharged from NPDES Storm Water Outfalls...................... 178

Table 11-2 Average Radiological Concentrations (pCi/1) for Storm Water Outfalls NP-0002, NP-0003, NP-0005 Baseline Monitoring for September 1994 to February 1995 186

Table 11-3 Average Chemical Concentrations $(\mu \mathrm{g} / \mathrm{l})$ for Storm Water Outfalls NP-0002, NP-0003, and NP-0005 Baseline Monitoring for September 1994 to February 1995. 187 


\section{INTRODUCTION}

The Weldon Spring Site Remedial Action Project (WSSRAP) is part of the U.S. Department of Energy (DOE) Environmental Restoration Program, one of the remedial action programs under the direction of the DOE Office of Environmental Management. This Site Environmental Report for Calendar Year 1997 summarizes the environmental monitoring results obtained in 1997 and presents the status of Federal and State compliance activities.

DOE requirements for environmental monitoring and protection of the public, the mandate for this document, are designated in DOE Order 5400.1, General Environmental Protection Program, DOE Order 5400.5, Radiation Protection of the Public and Environment, and the implementation guide for DOE Order 5400.5: Environmental Regulatory Guide for Radiological Effluent Monitoring and Environmental Surveillance (Ref. 1).

In 1997, environmental monitoring activities were conducted to support remedial action under the Comprehensive Environmental Response, Compensation and Liability Act (CERCLA), the Clean Air Act (CAA), the National Environmental Policy Act (NEPA), the Clean Water Act (CWA), and other applicable regulatory requirements. The monitoring program at the WSSRAP has been designed to protect the public and to evaluate the effects on the environment, if any, from remediation activities.

The purposes of the Site Environmental Report for Calendar Year 1997 include:

- Providing general information on the WSSRAP and the current status of remedial activities.

- Presenting summary data and interpretations for the 1997 environmental monitoring program.

- Providing information regarding ongoing remedial actions.

- Reporting compliance with Federal, State, and local requirements and DOE standards.

- Providing dose estimates for radiological compounds as appropriate for the WSSRAP.

- Summarizing trends and/or changes in contaminant concentrations to support remedial actions, ensure public safety, and maintain surveillance monitoring requirements. 


\subsection{Site Description}

The Weldon Spring site is located in southern St. Charles County, Missouri approximately $48 \mathrm{~km}(30 \mathrm{mi})$ west of St. Louis (Figure 1-1). The site consists of two main areas, the Weldon Spring Chemical Plant and raffinate pits and the Weldon Spring Quarry, both located along Missouri State Route 94 . Access to both the site and quarry is restricted by locked chain link fences with on-site security.

The Weldon Spring Chemical Plant is a 67.2 ha (166 acres) area that operated as the Weldon Spring Uranium Feed Materials Plant (WSUFMP) until 1966. Buildings were contaminated with asbestos, hazardous chemical substances, uranium, and thorium. (Building dismantlement was completed in 1994.) Radiological and chemical (polychlorinated biphenyls [PCBs], nitroaromatic compounds, metals and inorganic ions) contaminants can also be found in the soil in several areas around the site. The raffinate pits are located on the chemical plant site and consist of four settling basins that cover approximately 10.5 ha (26 acres) (Figure 1-2). These pits are radiologically contaminated with uranium and thorium residues and chemical contaminants including nitrate, fluoride, PCBs, and various heavy metals.

The Weldon Spring Quarry is a former 3.6 ha (9 acres) limestone quarry located southsouthwest of the chemical plant area (Figure 1-3). The quarry is essentially a closed basin; surface water within the rim flows to the quarry floor and into a sump. The amount of water in the sump varies in response to quarry water treatment plant operations and precipitation. The quarry bulk waste removal operation was completed in 1995. The bulk waste contained radiological and chemical contaminants including uranium, radium, thorium, metals, nitrates, PCBs, semivolatile organic compounds, nitroaromatics, and asbestos.

\subsection{Site History}

From 1941 to 1945 , the U.S. Department of the Army produced trinitrotoluene (TNT) and dinitrotoluene (DNT) at the Weldon Spring Ordnance Works, which covered 6,974 ha $(17,233$ acres) of land that now includes the Weldon Spring site. By 1949, all but about 809 ha (2,000 acres) had been transferred to the State of Missouri (August A. Busch Memorial Conservation Area) and to the University of Missouri (agricultural land). Except for several small parcels transferred to St. Charles County, the remaining property became the Army training area.

Through a Memorandum of Understanding between the Secretary of the Army and the General Manager of the Atomic Energy Commission (AEC), 83 ha (205 acres) of the former ordnance works property were transferred in May 1955 to the AEC for construction of the WSUFMP, now referred to as the Weldon Spring Chemical Plant. Considerable explosives 


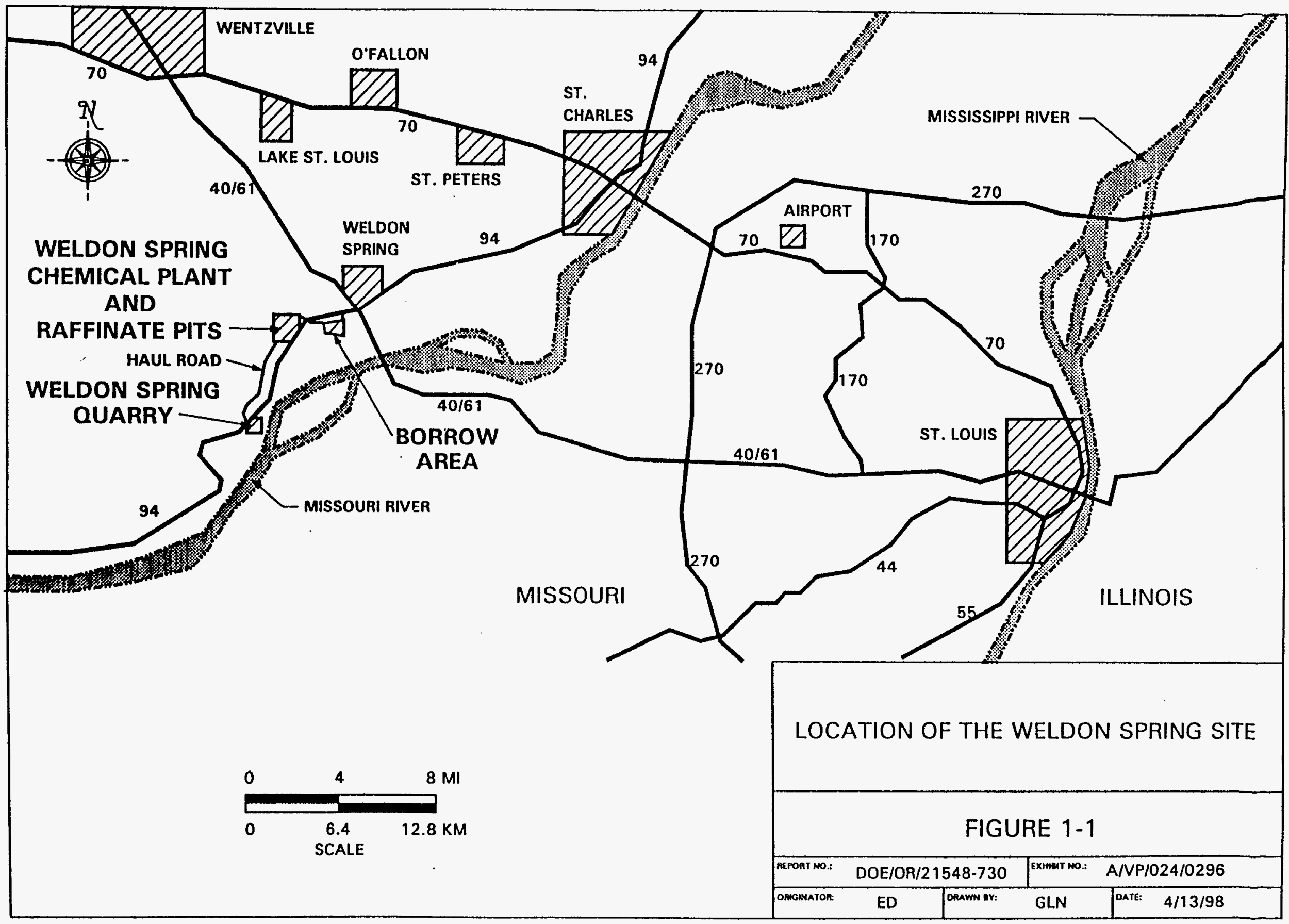




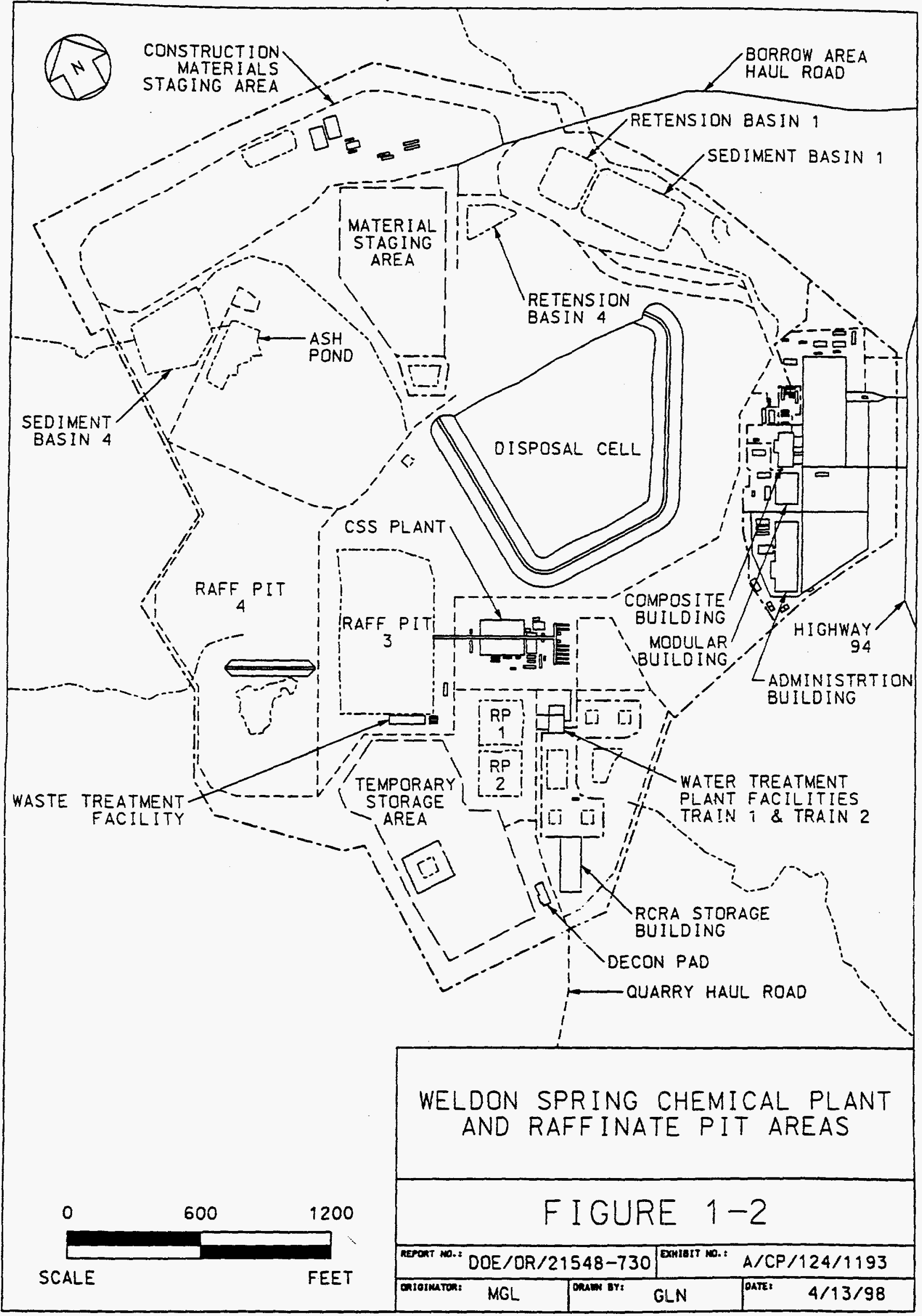




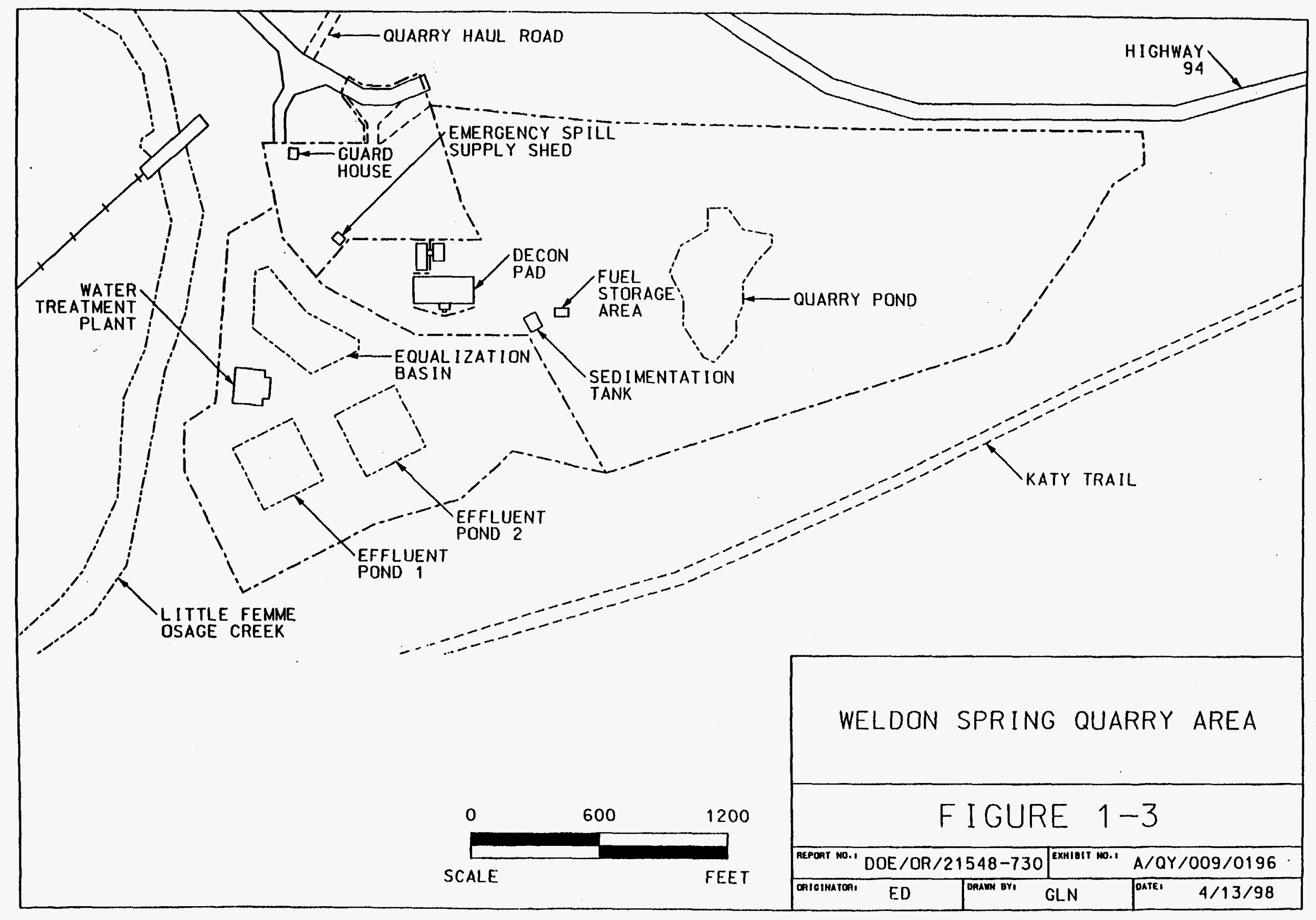


decontamination was performed by the Atlas Powder Company and the Army prior to WSUFMP construction. From 1958 until 1966, the WSUFMP converted processed uranium ore concentrates to pure uranium trioxide, intermediate compounds, and uranium metal. A small amount of thorium was also processed. Wastes generated during these operations were stored in the four raffinate pits.

In 1958, the AEC acquired title to the Weldon Spring Quarry from the Army. The Army had used it since 1942 for burning wastes from the manufacture of TNT and DNT and disposal of TNT-contaminated rubble during the operation of the ordnance works. Prior to 1942 , the quarry was mined for limestone aggregate used in the construction of the ordnance works. The AEC used the quarry from 1963 to 1969 as a disposal area for uranium residues and a small amount of thorium residue. Material disposed of in the quarry during this time consisted of building rubble and soils from the demolition of a uranium ore processing facility in St. Louis. These materials were contaminated with uranium and radium. Other radioactive materials in the quarry include drummed wastes, uncontained wastes, and contaminated process equipment.

The WSUFMP was shut down in 1966, and in 1967 the AEC returned the facility to the Army for use as a defoliant production plant to be known as the Weldon Spring Chemical Plant. The Army started removing equipment and decontaminating several buildings in 1968 . However, the defoliant project was canceled in 1969 before any process equipment was installed. The Army retained responsibility for the land and facilities of the chemical plant, but the 20.6 ha (51 acre) tract encompassing the Weldon Spring raffinate pits was transferred back to the AEC.

The Weldon Spring site was placed in caretaker status from 1981 through 1985, when custody was transferred from the Army to the Department of Energy. In 1985, the DOE proposed designating control and decontamination of the chemical plant, raffinate pits, and quarry as a major project. A Project Management Contractor (PMC) for the Weldon Spring Site Remedial Action Project was selected in February 1986. In July 1986, a DOE project office was established on site, and the PMC, MK-Ferguson and Jacobs Engineering Group, Inc., assumed control of the site on October 1, 1986. The quarry was placed on the Environmental Protection Agency's National Priorities List (NPL) in July 1987. The DOE redesignated the site as a Major System Acquisition in May 1988. The chemical plant and raffinate pits were added to the NPL in March 1989.

A more detailed presentation of the production, ownership, and waste history of the Weldon Spring site is available in the Remedial Investigation for Quarry Bulk Wastes (Ref. 2) and the Remedial Investigation for the Chemical Plant Area of the Weldon Spring Site (Ref. 3). 


\subsection{Geology and Hydrogeology}

The Weldon Spring site is situated near the boundary between the Central Lowland and the Ozark Plateau physiographic provinces. This boundary nearly coincides with the southern edge of Pleistocene glaciation that covered the northern half of Missouri over 10,000 years ago (Ref. 4).

The uppermost bedrock units underlying the Weldon Spring Chemical Plant are the Mississippian Burlington and Keokuk Limestone. Overlying the bedrock are unlithified units consisting of fill, top soil, loess, glacial till and limestone residuum of thicknesses ranging from a few feet to several tens of feet.

There are three bedrock aquifers underlying St. Charles County. The shallow aquifer consists of Mississippian Limestones and the middle aquifer consists of the Ordovician Kimmswick Limestone. The deep aquifer includes formations from the top of the Ordovician St. Peter Sandstone to the base of the Cambrian Potosi Dolomite. Alluvial aquifers of Quaternary age are present near the Missouri and Mississippi Rivers.

The Weldon Spring Quarry is located in low limestone hills near the northern bank of the Missouri River. The mid-Ordovician bedrock of the quarry area includes in descending order, the Kimmswick Limestone, Decorah Formation, and Plattin Limestone. These formations are predominantly limestone and dolomite. Near the quarry, the carbonate rocks dip to the northeast at a gradient of $11 \mathrm{~m} / \mathrm{km}$ to $15 \mathrm{~m} / \mathrm{km}(58 \mathrm{ft} / \mathrm{mi}$ to $79 \mathrm{ft} / \mathrm{mi})($ Ref. 4$)$. Massive quaternary deposits of Missouri River alluvium cover the bedrock to the south and east of the quarry.

\subsection{Surface Water System and Use}

The chemical plant and raffinate pits area is located on the Missouri-Mississippi River surface drainage divide (Figure 1-4). Elevations on the site range from approximately $185.4 \mathrm{~m}$ $(608 \mathrm{ft})$ above mean sea level $(\mathrm{msl})$ near the northern edge of the site to $205 \mathrm{~m}(673 \mathrm{ft})$ above msl near the southern edge. The topography of the site is gently undulating in the upland areas, typical of the Central Lowlands physiographic province. South of the site, the topography changes to the narrow ridges and valleys and short, steep streams common to the Ozark Plateau physiographic province (Ref. 4). There were eight surface water bodies at the chemical plant area during 1997: four raffinate pits, Ash Pond, Frog Pond, the chipped wood storage area pond, and the material staging area (MSA) pond. Portions of Ash Pond were capped in late 1994, and as a result, Ash Pond does not accumulate water unless the valve on the discharge structure is closed. The capacity of Frog Pond was permanently reduced in 1995 when the water level was lowered to allow remediation adjacent to the pond. 


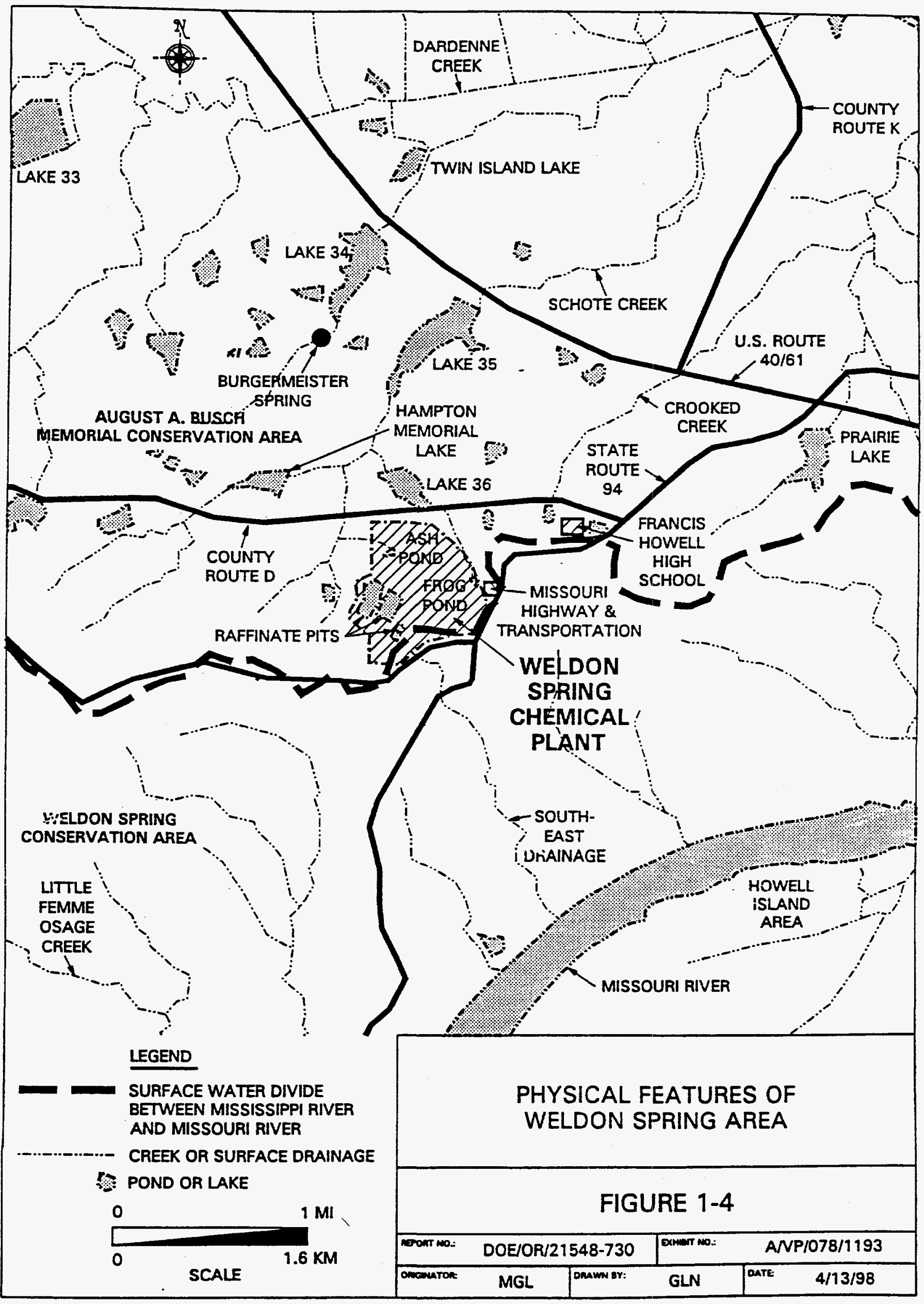


No natural drainage channels traverse the site, although remnants of a channel through the Ash Pond area are present. Drainage from the southeastern portion of the site generally flows southward to a tributary referred to as the Southeast Drainage (5300 Drainageway) that flows to the Missouri River.

In the surrounding areas, man-made lakes in the August A. Busch Memorial Conservation Area are used for public fishing and boating. No swimming is allowed in the conservation area, although some may occur. No surface water is used for irrigation or as a public drinking water supply. The northern and western portions of the site, including the Frog Pond and Ash Pond areas, drain to tributaries of Busch Lakes and Schote Creek, which in turn enter Dardenne Creek, which ultimately drains to the Mississippi River.

Four sedimentation basins minimize the discharge of sediment from the site during remediation efforts. One basin is downstream of Ash Pond and collects Ash Pond runoff water as well as all waters that discharge at Outfall NP-0003 (see Section 7). A second basin collects most water from the northeast section of the site and discharges to Outfall NP-0002. The third basin collects water from the site water treatment plant area and discharges to Outfall NP-0005. The fourth is just upstream of NP-0010 and collects runoff from a portion of the CMSA.

The Weldon Spring Quarry is situated on a bluff of the Missouri River valley about $1.6 \mathrm{~km}$ (1 mi) northwest of the Missouri River at approximately River Mile 49. No direct surface water runoff enters or exits the quarry due to the topography of the area. A 0.07 ha (0.2 acre) pond within the quarry proper acts as a sump that accumulates both direct rainfall within the quarry and the groundwater. Past dewatering activities in the quarry suggest that the sump interacts directly with the local groundwater. Bulk waste removal, which included removal of some sediment from the sump area, was completed at the quarry during 1995. The surface area of the sump remains at $0.07 \mathrm{ha}(0.2$ acres). The quarry pond is not used for any operational or public water supply and is maintained by the DOE within an access-controlled and restricted area.

The Femme Osage Slough, located approximately $213 \mathrm{~m}(700 \mathrm{ft})$ south of the quarry, is a $2.4 \mathrm{~km}(1.5 \mathrm{mi})$ section of the original Femme Osage Creek and Little Femme Osage Creek. The University of Missouri dammed portions of the creeks between 1960 and 1963 during construction of a levee system around the University's experimental farms (Ref. 5). The slough receives contaminated groundwater migrating from the quarry, causing increased uranium concentrations in the slough. The slough is used for recreational fishing.

\subsection{Ecology}

The Weldon Spring site is surrounded primarily by State Conservation Areas that include the 2,828 ha $(6,988$ acres) Busch Conservation Area to the north, the 2,977 ha (7,356 acres) Weldon Spring Conservation Area to the east and south, and the Howell Island Conservation 
Area, an island in the Missouri River which covers 1,031 ha (2,548 acres) (Figure 1-4). The wildlife areas are managed for multiple uses, including timber, fish and wildlife habitat, and recreation. Fishing comprises a relatively large portion of the recreational use. Seventeen percent of the area is open fields that are leased to sharecroppers for agricultural production. In these areas, a percentage of the crop is left for wildlife use. The main agricultural products are corn, soybeans, milo, winter wheat, and legumes (Ref. 6). The Busch and Weldon Spring Conservation Areas are open year-round, and the number of annual visits to both areas totals about 1,200,000.

The quarry is surrounded by the Weldon Spring Conservation Area, which consists primarily of forest with some old field habitat. Prior to bulk waste removal, the quarry floor consisted of old-field habitat containing a variety of grasses, herbs, and scattered wooded areas. Since bulk waste removal began this habitat has been disturbed. The rim and upper portions of the quarry still consist primarily of slope and upland forest including cottonwood, sycamore, and oak (Ref. 5).

\subsection{Climate}

The climate in the Weldon Spring area is continental with warm to hot summers and moderately cold winters. Alternating warm/cold, wet/dry air masses converging and passing through the area cause frequent changes in the weather. Although winters are generally cold and summers hot, prolonged periods of very cold or very warm to hot weather are unusual. Occasional mild periods with temperatures above freezing occur almost every winter and cool weather interrupts periods of heat and humidity in the summer (Ref. 7).

Long-term meteorological records (since 1870) for the St. Louis area were examined to obtain information relevant to the Weldon Spring site. The average annual temperature is $12.8 \mathrm{C}$ $\left(55.1^{\circ} \mathrm{F}\right)$. The average daily maximum and minimum temperatures are $19^{\circ} \mathrm{C}(66.2 \mathrm{~F})$ and $6.5^{\circ} \mathrm{C}$ $\left(43.8^{\circ} \mathrm{F}\right)$, respectively. Maximum temperatures above $32.2^{\circ} \mathrm{C}(90 \mathrm{~F})$ occur $35-40$ days per year. Minimum daily temperatures below $0^{\circ} \mathrm{C}(32 \mathrm{~F})$ occur about 111 days of the year. Temperatures below $-18^{\circ} \mathrm{C}\left(0^{\circ} \mathrm{F}\right)$ are infrequent, occurring only 2-3 days per year. Mean annual precipitation in the area is approximately $94.0 \mathrm{~cm}(37.0 \mathrm{in}$.).

Wind data recorded on site since 1994 indicate that prevailing winds are from the south and southwest. The average recorded wind speed is $2.9 \mathrm{~m} / \mathrm{s}(6.6 \mathrm{mph})$ from the south-southwest.

The meteorological station located at the chemical plant provides data to support site environmental monitoring programs. The station provides data on wind speed, wind direction, ambient air temperature, relative humidity, solar radiation, barometric pressure, and precipitation accumulation. Data from this station are used to assess meteorological conditions and air transport and diffusion characteristics, which help determine possible impacts of airborne 
contaminant releases. In addition, precipitation data are used to correlate water level fluctuations and contaminant concentrations in surface water and groundwater wells.

On-site meteorological data recovery exceeded $99 \%$ in 1997 . The quality of all data was assured by a qualified off-site meteorologist. Averages and totals are presented in Table 1-1. An annual wind rose is presented as Figure 1-5.

\subsection{Land Use and Demography}

The population of St. Charles County in 1997 was 264,275. The county's population increased by about $20 \%$ from 1990 to 1997 . The two communities closest to the site are Weldon Spring and Weldon Spring Heights, about $3.2 \mathrm{~km} \mathrm{(2} \mathrm{mi)} \mathrm{to} \mathrm{the} \mathrm{northeast.} \mathrm{The} \mathrm{combined}$ population of these two communities in 1996 was 1,265 (Appendix A). No private residences exist between Weldon Spring Heights and the site.

Francis Howell High School and the Missouri Highway and Transportation Department are both within $1 \mathrm{~km}(0.6 \mathrm{mi})$ of the site. Francis Howell High School is about $1 \mathrm{~km}(0.6 \mathrm{mi})$ northeast of the site along Missouri State Route 94. The school employs approximately 180 faculty and staff, and about 1,850 students attend school there (Appendix A). Students and staff generally spend about 7 hours to 8 hours per day at the school. The buildings are also used for other activities, such as athletic events and school meetings. The Missouri Highway and Transportation Department, located adjacent to the northern boundary of the chemical plant, employs nine full-time employees (Appendix A). About 300 ha (741 acres) of land east and southeast of the high school is owned by the University of Missouri. The northern third of this land is being developed into a high-technology research park. The conservation areas, operated by the Missouri Department of Conservation, employ 40 full-time and part-time employees, including seasonal help during the summer months (Appendix A). 
Table 1-1 Monthly Meteorological Monitoring Results for 1997

\begin{tabular}{|l|l|l|l|l|}
\hline \multicolumn{1}{|c|}{ MONTH } & \multicolumn{1}{|c|}{$\begin{array}{c}\text { TOTAL PRECIP } \\
\text { (CM) }\end{array}$} & $\begin{array}{c}\text { AVERAGE TEMP } \\
\text { (DEGREES C) }\end{array}$ & $\begin{array}{c}\text { AVERAGE WIND } \\
\text { SPEED (M/SEC) }\end{array}$ & \multicolumn{1}{|c|}{$\begin{array}{c}\text { PREDOMINANT WIND } \\
\text { DIRECTION }\end{array}$} \\
\hline January & 5.56 & -2.7 & 3.5 & WNW \\
\hline February & 11.58 & 3.0 & 3.0 & NW \\
\hline March & 6.93 & 8.8 & 3.7 & SSW \\
\hline April & 7.16 & 10.6 & 3.2 & SSW \\
\hline May & 13.74 & 16.2 & 3.3 & NW \\
\hline June & 5.18 & 21.9 & 2.4 & S \\
\hline July & 0.56 & 25.7 & 2.3 & S \\
\hline August & 9.53 & 23.6 & 2.1 & SSW \\
\hline September & 3.68 & 20.3 & 2.4 & S \\
\hline October & 5.89 & 14.2 & 2.7 & S \\
\hline November & 10.69 & 5.3 & 2.9 & SSW \\
\hline December & 5.38 & 1.2 & 3.0 & WNW \\
\hline $\begin{array}{l}\text { Annual Average/ } \\
\text { Total }\end{array}$ & $85.88(33.8$ in.) & $12.3\left(54.2^{\circ} \mathrm{F}\right)$ & $2.9(6.4 \mathrm{mph})$ & SSW (11.5\%) \\
\hline
\end{tabular}




\section{Wind Direction and Speed Distribution}

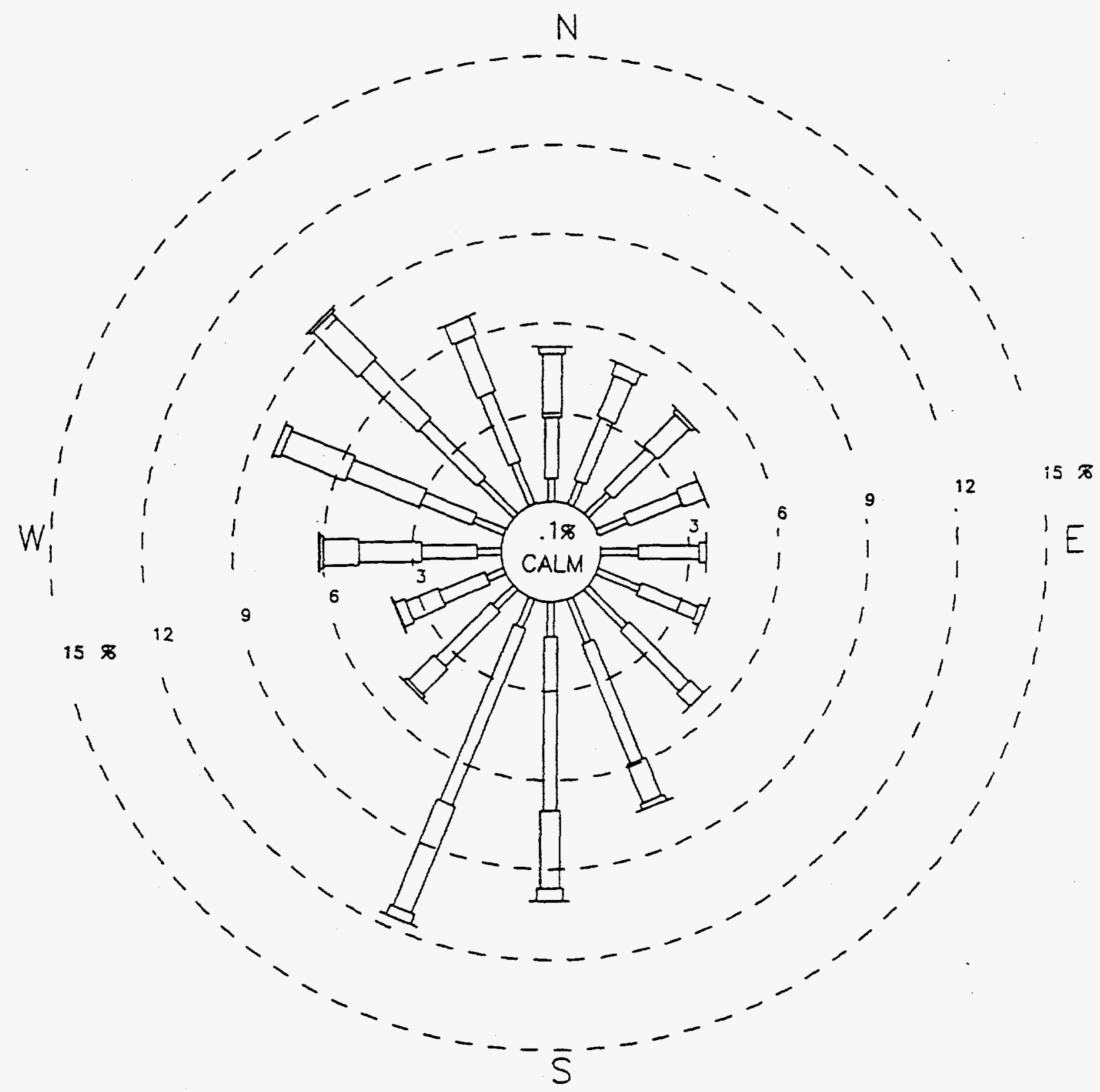

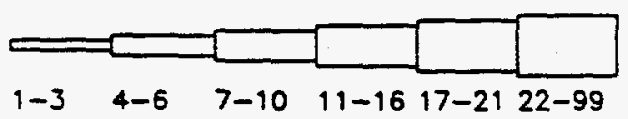

$(19 x)(45 x)(27 x)(9 x)(1 x)(0 x)$

WIND SPEED SCALE (MPH)

NOTE: WIND DIRECTION IS THE DIRECTION WIND IS BLOWING FROM
1997 WINDROSE

WELDON SPRING SITE

METEORLOGICAL STATION
FIGURE 1-5

\begin{tabular}{|c|c|c|c|c|c|}
\hline montr 10: & DOE/C & $548-730$ & OAMart ta: & & 10498 \\
\hline omerutor: & ED & omamuar: & GLN & Date: & $4 / 13 / 98$ \\
\hline
\end{tabular}




\section{ENVIRONMENTAL PROTECTION/RESTORATION PROGRAM OVERVIEW}

\subsection{Project Purpose}

The U.S. Department of Energy (DOE) is responsible for the remedial action activities at the Weldon Spring site. The program is known as the Weldon Spring Site Remedial Action Project (WSSRAP). The major goals of the WSSRAP are to eliminate potential hazards to the public and the environment posed by the waste materials on the Weldon Spring site and, to the extent possible, make surplus real property available for other uses.

Remedial actions are subject to U.S. Environmental Protection Agency (EPA) oversight under the Comprehensive Environment Response, Compensation and Liability Act (CERCLA). Remedial actions at the site are subject to CERCLA requirements because the site is listed on the EPA National Priorities List (NPL). Section 3 of this document further discusses applicable Federal, State, and local compliance requirements and the current status of compliance activities at the Weldon Spring site and incorporating National Environment Policy Act (NEPA) values into CERCLA documents as outlined in the secretarial policy statement on NEPA.

\subsection{Project Management}

In order to manage the WSSRAP under the CERCLA, the proposed strategy for remedial activities at the Weldon Spring site is organized into the following four separate operable units: Weldon Spring Quarry Bulk Waste, Weldon Spring Chemical Plant, Groundwater, and Quarry Residuals. The Weldon Spring Quarry Bulk Waste Operable Unit includes all wastes deposited in the quarry and their removal. The Weldon Spring Chemical Plant Operable Unit includes the buildings, soils, raffinate pits, quarry bulk wastes that have been relocated to the temporary storage area (TSA), and surface waters within the chemical plant boundary and vicinity properties. The Groundwater Operable Unit includes the groundwater at the chemical plant and vicinity areas. The Quarry Residuals Operable Unit includes the quarry proper (post-bulk waste removal), surrounding areas, surface waters, and groundwaters.

\subsection{Environmental Monitoring Program Overview}

The overall goal of the WSSRAP is different from that of most operating and production facilities for which DOE Order 5400.1, General Environmental Protection Program, was developed. At the WSSRAP, environmental monitoring is conducted as required by DOE Order 5400.1 to measure and monitor effluents and to provide surveillance of effects on the environment and public health. In addition to these objectives, environmental monitoring activities support remedial activities under the CERCLA. This requires a careful integration of WSSRAP activities to implement all the environmental and public health requirements of the CERCLA, DOE orders, and other relevant Federal and State regulations. 
The WSSRAP also complies with DOE Order 5400.1 requirements for preparation and maintenance of an Environmental Protection Program Implementation Plan (EPPIP) (Ref. 8) and an Environmental Monitoring Plan (EMP) (Ref.42). The EPPIP details the programs in place at the WSSRAP to provide management direction, environmental protection goals and objectives, the remedial status of the project, and the overall framework of the environmental protection program at the WSSRAP. The EMP details the schedule and analyses for performing effluent monitoring and surveillance activities.

The WSSRAP environmental protection program involves radiological and chemical environmental monitoring and is separated into two distinct functions: effluent monitoring and environmental surveillance. Effluent monitoring assesses the quantities of substances in environmental media at the facility boundary, in contaminant migration pathways, and in pathways subject to compliance with applicable regulations (e.g., National Emission Standards for Hazardous Air Pollutants [NESHAPs]). Environmental surveillance consists of analyzing environmental conditions within or outside the facility boundary for the presence and concentrations of site contaminants. The purpose of this surveillance is to detect and/or track the migration of contaminants. Surveillance data are used to assess the presence and magnitude of radiological and chemical exposures and to assess the potential effects to the general public and the environment.

The WSSRAP environmental monitoring program involves sampling various media for radiological constituents; primarily U-234, U-238, $\mathrm{Ra}-226, \mathrm{Ra}-228, \mathrm{Th}-230$ and $\mathrm{Th}-232$. These radionuclides are the primary radiological contaminants of concern at the Weldon Spring site. Radiological monitoring is conducted routinely at perimeter locations and at off-site locations near the chemical plant and quarry for air particulates, ambient gamma radiation, and radon. Radiological monitoring is also conducted on National Pollutant Discharge Elimination System (NPDES) discharges, streams, lakes, ponds, groundwater and springs.

Chemical monitoring is primarily conducted at the chemical plant and quarry areas, but also includes monitoring at off-site locations to confirm that no releases have occurred. The nonradiological compounds included in the routine 1997 monitoring program are metals, inorganic ions (nitrate and sulfate) and nitroaromatic compounds. Other non-radiological parameters monitored as part of the environmental monitoring program include asbestos at site perimeter air monitoring locations.

\subsection{Project Accomplishments in 1997}

Several activities were completed in 1997 under the overall plan for remediation of the site. All four operable units were currently active, and major accomplishments for the units are detailed below. 


\subsubsection{Weldon Spring Chemical Plant Operable Unit}

\subsubsection{Site Water Treatment Plant}

Ongoing discharges of treated water into the Missouri River have consistently been below the effluent standards set forth in the conditions of the chemical plant's NPDES permit. During 1997, 36.3 million liters (9.6 million gallons) of contaminated water were treated and discharged.

\subsubsection{RCRA/TSCA Storage}

The Resource Conservation and Recovery Act (RCRA) and Toxic Substances Control Act (TSCA) storage facilities, Building 434, and TSA (temporary storage area), activities included the transfer and off-site disposal of approximately 10 containers to the K-25 incinerator in Oak Ridge, Tennessee. Forty-one 4-cu-yd boxes of filtercake were emptied at the TSA. Other activities included returning numerous laboratory samples to the original containers, compacting approximately 342 drums of radiological trash and personal protective equipment (PPE).

A contract was established with Commodore/ASI to perform a Work Package - Organic Waste Treatability Study using Solvated Electron Technology. Contract preparations, demonstration plan finalization, submittal preparations, and on-site training were performed during October. In November, equipment and personnel were mobilized to the WSSRAP, and the treatment system in the Building $434 \mathrm{~A}$-berm was set up. Wastes to be treated include polychlorinated biphenyls (PCBs), other chlorinated organic compounds, and non-chlorinated aromatic unsaturated hydrocarbons present in 39 containers. Treatment requirements are based upon the specific waste container regulatory status pursuant to RCRA and TSCA. Ten batches were treated in December. Pre-treatment PCB concentrations have ranged from $673 \mathrm{ppm}$ to $1,310 \mathrm{ppm}$, and post-treatment PCB concentrations from $0.1 \mathrm{ppm}$ to $72 \mathrm{ppm}$. PCB destruction efficiencies demonstrated a range from $91.3 \%$ to $99.8 \%$. Treatability study activities resumed in January 1998.

\subsubsection{Disposal Cell}

Phase 1 of the disposal cell was substantially completed in 1997. Activities included starter dike and berm construction, placement of liners, Leachate Collection and Removal System (LCRS) piping, and placement of gravel layers.

Approximately $672,000 \mathrm{cu}$ yd of material were removed from the Borrow Area (including the contingency area) for use in disposal cell construction or placement in the megapile, from which all future low perm and common fill material will be obtained. All areas outside the stockpiles are graded and reseeded, awaiting final restoration pending release to the Missouri Department of Conservation. 
The WSSRAP-Modified Toxicity Characteristic Leaching Procedure (TCLP) sampling effort was initiated in May 1997. This effort encompassed the sampling and evaluation of basic leachate from major waste streams to determine whether contaminant concentrations conform with the "as low as reasonably achievable" (ALARA) policy. A draft report is currently being completed.

Collection of 1-year baseline groundwater data for the disposal cell compliance monitoring well network was initiated in January 1997, with quarterly sampling events planned and completed in the first quarter of 1998.

A pilot scale study for treatment of nitroaromatically contaminated soils at the TSA began in November 1997. The soils were treated in situ through a chemical stabilization and solidification (CSS) process, by disking the soil with fly ash and cement. Treatment was completed in February 1998.

\subsubsection{CSS Full Scale}

The CSS Production Facility is a processing plant with the designated purpose of stabilizing the raffinate sludges currently stored in Raffinate Pits $1,2,3$, and 4, preparatory to their placement in the on-site disposal cell for long-term entombment. The mission of the CSS Production Facility is to blend a mixture of fly ash and Portland cement into the raffinate sludges to produce a grout-like product that will then be placed in the disposal cell. After placement and hydration, the product solidifies, achieving adequate structural stability and strength.

The contract for the construction of the CSS Production Facility was awarded on April 22, 1997, to McCarthy Interface. The Notice to Proceed was received May 13, 1997. By the end of December, construction of the CSS Plant was $86 \%$ complete.

The contract for the dredge support system was awarded to Avisco on August 20, 1997. The Notice to Proceed was awarded on September 18, 1997. Approximately 90 pieces (1,000 linear feet) of contaminated steel, which originated from the building dismantlement, were used for lateral positioning system vertical supports in Raffinate Pits 3 and 4 . Reuse of this steel was part of the WSSRAP's waste minimization program.

\subsubsection{Raffinate Pits}

Biodenitrification activities in Raffinate Pits 1 and 2 destroyed 275 tons of nitrates that were bound in raffinate pit sludges. Raffinate Pit 2 sludge transfer was completed in September 1997. Approximately $4,500 \mathrm{cu}$ yd of residual raffinate sludge were removed from Raffinate Pit 2 and transferred to Raffinate Pit 3. A ramp was constructed to allow drilling equipment to access the pit bottom for engineering characterization, and $28,863 \mathrm{cu}$ yd of raffinate sludge from the 
north section of Raffinate Pit 4 were transferred to the south impoundment basin. About $49,556 \mathrm{cu}$ yd of unsuitable and contaminated soils were excavated and transported from Raffinate Pit 4 to the Ash Pond storage area. Raffinate Pit 4 confirmation sampling was initiated in September. Seven full confirmation units and one partial were completed by December 1997.

\subsubsection{Mixed Waste}

The WSSRAP began treatment of mixed wastes under the Federal Facility Compliance Act (FFCA) site treatment plan in February 1995. The plan consisted of eight treatability groups; (1) Aqueous Liquids; (2) Inorganic Sludges and Particulates; (3) Inorganic Debris, Metal, and Batteries; (4) Contaminated Debris; (5) Liquid Mercury; (6) Reactives and Oxidizers; (7) Organic Liquids 1; (8) Organic Liquids 2, and (9) Organic Sludges. The following treatability groups were treated and closed out in the 1996 Annual Update: (1) Aqueous Liquids, (2) Liquid Mercury, (3) and Organic Liquids. Nitroaromatic soils were added during 1996, and new treatability groups added during 1997 were Organic Liquids 2 and Selenium Water.

1. Aqueous Liquids: treatment of aqueous liquids was completed prior to 1997.

2. Inorganic Sludges/Particulates: during 1997, five drums from this treatability group were treated.

3. Inorganic Debris, Metal, and Batteries: no treatment occurred during this reporting period.

4. Contaminated Debris: the status of this treatability group did not change during 1997.

5. Liquid Mercury: treatment of this waste stream was completed prior to 1997.

6. Reactives/Oxidizers: completed treatment of this waste stream in 1997.

7. Organic Liquids 1: treatment of this treatability group was completed prior to 1997.

8. Organic Liquids 2: the TSCA/RCRA portion of Organic Liquids 2 (10 containers) was shipped to the K-25 incinerator in Oak Ridge, Tennessee on September 9, 1997.

9. Organic Sludges: the WSSRAP began coordinating acceptance of the Organic Sludges at K-25; however, due to delays and continued concern from the State of Tennessee regarding out-of-state shipments, the WSSRAP began pursuing other options and target dates. A contract was established with Commodore/ASI to perform treatment using Solvated Electron Technology (See Section 2.4.1.2). Ten batches of organic sludge waste were treated in December. 


\subsubsection{Lake 36}

Busch Lake 36 was sampled for characterization to support engineering remediation design. Sampling and analysis of lake sediments revealed that the average concentration of U-238 in the lake sediment was approximately $12 \mathrm{pCi} / \mathrm{g}$ and the highest measured concentration was approximately $90 \mathrm{pCi} / \mathrm{g}$. As a result of the characterization, the DOE made the decision not to remove and transport the sediments from the lake to storage areas at the chemical plant site for interim storage prior to placement in the disposal cell facility.

A meeting between the DOE, the Missouri Department of Conservation (MDC), the Missouri Department of Natural Resources (MDNR) and the Weldon Spring Site Citizens Commission was held to discuss the characterization results and the decision not to remove the sediment from the lake bed due to the lack of contamination above clean up criteria specified in the Record of Decision (ROD). An agreement was reached to remove approximately $400 \mathrm{cu}$ yd of sediment in and around the area of the highest measured U-238 contamination in the lake bed. The sediment was removed and transported to the chemical plant site of the Weldon Spring site during the week of September 8, 1997, and placed at the unsuitable soils stockpile southeast of the MSA.

\subsubsection{Weldon Spring Quarry Bulk Wastes Operable Unit}

This operable unit was officially closed out in April 1997 with the submission of the Quarry Bulk Waste Excavation Remedial Action Report (Ref. 80) to the U.S. Environmental Protection Agency (EPA), Region 7.

\subsubsection{Quarry Water Treatment Plant}

During 1997, the QWTP treated and discharged to the Missouri River approximately 10.6 million liters (2.8 million gallons) of contaminated water that met the effluent standards set forth in the National Pollutant Discharge Elimination System (NPDES) permit for the Weldon Spring Quarry.

\subsubsection{Weldon Spring Quarry Residuals Operable Unit}

In July 1997, the draft final versions of Remedial Investigation for the Quarry Residual Operable Unit of the Weldon Spring Site, Weldon Spring, Missouri (Ref. 81) and the Baseline Risk Assessment for the Quarry Residual Operable Unit of the Weldon Spring Site, Weldon Spring, Missouri (Ref. 82) were transmitted to the EPA, Region 7 and the Missouri Department of Natural Resources (MDNR) for review. The Remedial Investigation (Ref. 81) presents information on the nature and extent of contamination. Both documents were issued as final in February 1998. The Baseline Risk Assessment (Ref. 82) provides a combined baseline assessment 
of potential human health and ecological impacts that would be associated with this operable unit if no remedial action were taken.

On January 8, 1998, the draft final versions of the Feasibility Study for Remedial Action for the Quarry Residuals Operable Unit at the Weldon Spring Site, Weldon Spring, Missouri (Ref. 81) and the Proposed Plan for Remedial Action for the Quarry Residuals Operable Unit at the Weldon Spring Site, Weldon Spring, Missouri (Ref. 83) were transmitted to the EPA and MDNR for review. Comments were received on February 11, 1998. After incorporation of comments, these documents were issued as final in March 1998. The Feasibility Study was prepared to evaluate potential options for addressing contamination at the operable unit in accordance with the integrated environmental compliance process for the WSSRAP.

Remediation of any of the components of the operable unit for risk reduction is not indicated based on the assessments from the Remedial Investigation and Baseline Risk Assessment. However, because of the potential for uranium in groundwater in the area of the quarry to migrate to the nearby St. Charles County well field, the primary objective of the Feasibility Study was to identify an alternative that would provide a feasible and cost effective option for removing or reducing the amount of uranium that is currently present in the groundwater north of the slough thereby adding to the already protective conditions in the well field. The alternatives presented in the Feasibility Study are:

Alternative 1: No action

Alternative 2: Monitoring with no active remediation

Alternative 3: Groundwater removal with on-site treatment

Alternative 4: Containment

Alternative 5: In situ treatment using permeable barriers

Alternative 6: Groundwater removal at selected areas with on-site treatment

The Proposed Plan was made available to the public for review and comment from March 17 through April 22, 1998. A public meeting to discuss the preferred remedial alternative for this operable unit was held on April 16, 1998. Comments were received by both the State agencies and representatives of the public.

\subsubsection{Weldon Spring Groundwater Operable Unit}

The Remedial Investigation and the Baseline Risk Assessment were finalized in July 1997. The contaminants of potential concern were identified as uranium, nitroaromatic compounds, nitrate, sulfate, chloride, lithium, molybdenum, TCE, and 1,2-DCE (Ref. 84). Contamination in groundwater is generally confined to the shallow, weathered portion of the uppermost bedrock unit, the Burlington-Keokuk Limestone.

DOE/OR/21548-730, Rev. 0 
The draft Feasibility Study (Ref. 85) was submitted to the Federal and State Regulatory Agencies in October 1997 and the draft final report was submitted in April 1998. A review of applicable technologies and proposed remedial action was presented in the Feasibility Study. A final decision for remedial action for groundwater is pending regulatory review in 1998 and 1999.

\subsection{Incident Reporting - Environmental Occurrences in 1997}

In accordance with DOE Order 5400.1, Chapter II, 2.(b), field organizations are required to prepare annual summary reports on environmental occurrence activities and to report this information in the annual site environmental report.

In 1997, three off-normal occurrences of an environmental nature were reported under DOE Order 232.1A, Occurrence Reporting and Processing of Operations Information. Table 2-1 lists these environmental occurrences for 1997, and a short description of each occurrence is provided in the following paragraphs.

Table 2-1 Environmental Occurrences CY 1997

\begin{tabular}{|l|c|c|}
\hline OCCURRENCE REPORT NUMBER & OCCURRENCE DATE & SUBJECT OF OCCURRENCE \\
\hline $1997-0001$ & $02 / 20 / 97$ & NPDES violation at Outfall NP-002 \\
\hline $1997-0009$ & $08 / 15 / 97$ & NPDES violation at Outfall NP-002 \\
\hline $1997-0010$ & $08 / 15 / 97$ & NPDES violation at Outfall NP-003 \\
\hline
\end{tabular}

Occurrence 1997-0001 involved an NPDES sample that was collected on February 20, 1997 from Outfall NP-0002. The sample was collected at 1020 hours and the flow at the time was very heavy (2900 gpm). Settleable solids were measured at $5.5 \mathrm{ml} / /$ hour, which is above the $1.0 \mathrm{ml} / /$ hour permitted limit. The MDNR was notified. Corrective actions included installing a silt fence, placing two sandbags and installing a rock check dam.

Occurrence 1997-0009 involved a sample collected during a 1-in. rainfall event on August 15,1997 from Outfall NP-0002. The samples results showed settleable solids were $55 \mathrm{ml} / /$ hour with a flow of $341 \mathrm{gal}$ per minute. This is over the permitted limit for settleable solids; therefore, the MDNR was notified. Letters were submitted to the MDNR and Missouri State Water Pollution Control Program office. A meeting was held with MDNR to discuss the permit exceedence and the PMCs proposed revision to the NPDES permit.

Occurrence 1997-0010 involved a storm water sample collected at Outfall NP-0003 on August 15, 1997 from Outfall NP-0003. There was approximately 1 in. of rainfall prior to sample collection. The preliminary results revealed chromium at a level of $111 \mu \mathrm{g} / 1$. These results were confirmed September 10, 1997, and the MDNR was notified regarding the NPDES Permit Special Condition 3 exceedence of chromium.

No reportable releases occurred during this reporting period. 


\subsection{Special DOE Order Related Programs}

In addition to the direct program requirements and documentation required under DOE Order 5400.1, the DOE order specifically requests that other programs be presented in the annual site environment report, including the groundwater protection management program, the meteorological monitoring program, and the waste minimization and pollution prevention program. This section also addresses other programs, under DOE Order 5482.1B, such as self assessments, the radiological control program, and the surface water management program at the WSSRAP.

\subsubsection{Groundwater Protection Management Program}

The WSSRAP has a formal groundwater protection and management program in place. The policies and practices are documented in the Groundwater Protection Program Management Plan (Ref. 13). The plan outlines how monitoring programs will be developed to assess the nature and extent of contaminants in the groundwater, to evaluate potential impacts on public health, and to gather data for remedial decisions. All policies pertaining to groundwater monitoring, including well installation, decontamination, construction, sampling methods, and abandonment methods, are detailed in this plan. The plan outlines the hydrogeological characterization program conducted as part of CERCLA activities. These include groundwater sampling, water level monitoring, slug tests, tracer tests, and geologic logging.

The plan is currently in revision and will be referred to as the WSSRAP Groundwater Protection Management Plan, which is expected to be completed in 1998. The revised program will include those practices and policies described above, as well as recently developed strategies for implementing site-wide groundwater protection practices and interdepartmental integration of these practices during all aspects of project management and development. Additionally, the practices and policies have been reviewed and revised to comply with the proposed Federal Regulation 10 CFR 834 Radiation Protection of the Public and the Environment, Draft, 1996.

\subsubsection{Meteorological Monitoring Program}

A meteorological station is located at the chemical plant to provide data to support the environmental monitoring programs. The meteorological station provides data on wind speed, wind direction, ambient air temperature, relative humidity, barometric pressure, solar radiation, and precipitation accumulation. Data from this station are used to assess meteorological conditions and air transport and diffusion characteristics, which determine possible impacts of airborne releases. In addition, precipitation data are used to correlate water level fluctuations and contaminant concentrations in surface water and groundwater wells. 
Since the completion of a system upgrade in August 1994, meteorological data recovery has exceeded $99 \%$. An off-site meteorologist provides monthly data reviews and semiannual maintenance and performance checks for the station.

\subsubsection{Surface Water Management Program}

The WSSRAP maintains a surface water management program to ensure effective implementation of policies detailed in DOE Order 5400.5 and documented in the Surface Water Management Plan (Ref.14). This program also incorporates the ALARA concept in the execution of the program.

This plan identifies existing and potential water sources, water quality categories, and provides the requirements and methodologies for proper control, management, and disposition of site waters. Erosion and water control, and water management for the quarry and site water treatment plants are also discussed. The key elements of the plan are source identification, characterization, monitoring, engineering controls, and management methods.

\subsubsection{Radiation Protection Program}

The U.S. Department of Energy issued 10 CFR 835 (Occupational Radiation Protection), in December 1993 in the Federal Register; 10 CFR 835 sets the minimum acceptable occupational radiological control standards for DOE facilities. The regulation includes requirements for contamination control; ALARA practices; internal and external dosimetry; facility design and control; internal surveillances; instrumentation and calibration; worker training, posting and labeling, and release of materials from radiological areas.

As of December 31,1997, the WSSRAP is in full compliance with all applicable sections of 10 CFR 835 .

\subsubsection{Waste Management Program}

The waste management program involves the characterization, storage, and management of various chemicals and wastes found on site. Hazardous and mixed wastes are stored in the onsite RCRA and TSCA storage facilities like Building 434, the TSA and the asbestos storage area (ASA). Other wastes and materials can be found in all storage areas. There are several satellite accumulation areas where waste materials are kept in small quantities at the source of generation. These wastes are later moved to on-site storage areas, dependent on waste types.

This program also encompasses the transportation program, including the packaging and shipping of hazardous and nonhazardous wastes and samples. During 1997, 977 shipments were shipped off site, 54 of which were regulated as hazardous materials. 


\subsubsection{Waste Minimization/Pollution Prevention Program}

The WSSRAP Waste Minimization Program is outlined in the Waste Minimization/Pollution Prevention Awareness Plan (Ref. 16) in accordance with the requirements of DOE Order 5400.1. Because long-term, volume-specific goals for waste minimization are not appropriate for nonoperational facilities, the WSSRAP has adopted ALARA goals.

The program is primarily geared toward material substitution and source or volume reduction minimization methods. This is accomplished by evaluating and reviewing all hazardous chemicals (as defined by 29 CFR 1926.59) before they are purchased or arrive on site, and recommending alternate materials or applying use restrictions. Additional methods routinely employed at the WSSRAP include removing packaging materials from products before they enter the radioactive materials management areas, limiting waste-generating activities during remediation and treatment, consolidating waste during storage, reviewing design specifications for possible methods to minimize waste generation, and segregating waste by waste types. The following is a detailed list of the waste minimization activities conducted during 1997.

- Used PPE is being compacted on site into 55-gallon containers for on-site storage. Compaction of the PPE will reduce the volume of waste placed in the disposal facility. During 1997, the WSSRAP generated 342 drums of compacted PPE.

- A surplus material inventory is being maintained for materials and equipment that can be reused as opposed to buying duplicates or potentially contaminating duplicate products when they are taken into the radioactive materials management areas. The inventory consists of materials and/or equipment that can be used again.

- One electrical transformer was sent back to the manufacturer. The parts will be reused.

- Nine nickel/cadmium lead batteries were sent back to the manufacturer for recycling.

- Three hundred and sixty four cu yd of cardboard, $208 \mathrm{cu}$ yd of paper, and 20,800 aluminum cans were collected by a recycler.

- Approximately 70 used tires were sent to a recycler.

- Approximately 300 toner cartridges were sent back to the manufacturer. Money from recycling cartridges will be donated to the Forestry Department. 
- Reusable cotton coveralls are being laundered and reused.

- The WSSRAP donated approximately 93 computers, 25 monitors, and miscellaneous computer equipment to a local high school under Executive Order 12821, which allows agencies to transfer educationally related Federal equipment to secondary schools.

- The WSSRAP donated approximately 70 gal of paint products, gas cans, ice packs, and other miscellaneous supplies to Habitat for Humanity.

- Four hundred linear feet of $7 \mathrm{ft}$ chain link fence were no longer needed at Raffinate Pit 4. Rather than purchasing fence for a new work package, this fence was reused.

- A total of $6.8 \mathrm{~kg}$ of incandescent and $318 \mathrm{~kg}$ of fluorescent light bulbs (this includes 137 thermometers and 82 switches) was shipped to a recycler.

- Approximately 1,920 linear $\mathrm{ft}$ of rail, six rail switches, and one Army mule were decontaminated. One thousand linear $\mathrm{ft}$ of the rail has been reused on site for the lateral positioning system vertical supports in Raffinate Pits 3 and 4. The rest of the materials and the mule were released and donated to the Museum of Transportation.

- A total of 16,115 gallons of used oil were sent to a recycler.

\subsubsection{Training}

Training is a key element of the environmental protection program. Through training, each employee is instructed in the policies and procedures related to environmental protection.

The training program can essentially be broken down into three main areas: (1) required reading, (2) special courses taught on site to convey specific policies or issues, and (3) off-site courses designed to provide instruction for specific areas. Department managers establish training matrixes for each employee to ensure a comprehensive understanding of position requirements and overall policies and program requirements. 


\section{COMPLIANCE SUMMARY}

\subsection{Compliance Status for 1997}

The Weldon Spring site is listed on the National Priorities List (NPL), and therefore the Weldon Spring Site Remedial Action Project (WSSRAP) is governed by the Comprehensive Environmental Response, Compensation and Liability Act (CERCLA) process. Under the CERCLA, the WSSRAP is subject to meeting or exceeding the applicable or relevant and appropriate requirements of Federal, State, and local laws and statues, such as the Resource Conservation and Recovery Act (RCRA), the Clean Water Act (CWA), the Clean Air Act (CAA), the National Historic Preservation Act (NHPA), the Safe Drinking Water Act (SDWA), Endangered Species Act, and Missouri State regulations. Because the U.S. Department of Energy (DOE) is the lead agency for the site, the National Environmental Policy Act (NEPA) values must be incorporated. The requirements of DOE Orders must also be met. Section 3.1.1 is a summary of WSSRAP compliance with applicable Federal and State regulations, and Section 3.1.2 is a summary of the WSSRAP compliance with major DOE Orders.

\subsubsection{Federal and State Regulatory Compliance}

Comprehensive Environmental Response, Compensation and Liability Act

The WSSRAP has integrated the procedural and documentation requirements of the CERCLA, as amended by the Superfund Amendments and Reauthorization Act (SARA), and the NEPA, as required by the policy stated in DOE Order 5400.4 .

\section{Resource Conservation and Recovery Act}

Hazardous wastes at the Weldon Spring site are managed as required by the RCRA as substantive applicable or relevant and appropriate (ARARs). This includes characterization, consolidation, inventory, storage, treatment, and transportation of hazardous wastes that remained on site after closure of the Weldon Spring Uranium Feed Materials Plant (WSUFMP) and wastes that are generated during remedial activities.

A RCRA treatment, storage, and disposal permit is not required at the site since remediation is being performed in accordance with decisions reached under the CERCLA. Section 121(e) of the CERCLA states that no Federal, State, or local permit shall be required for the portion of any removal or remedial action conducted entirely on site.

The RCRA was amended by the Federal Facility Compliance Act (FFCA), which was enacted on October 6,1992 . The site treatment plan for mixed waste, which was required by the FFCA was finalized with a consent agreement with the MDNR in October 1995 . The 1997 
Annual Update to the Site Treatment Plan for the Weldon Spring Site (Ref. 72) was submitted to the MDNR October 15, 1997. The Update included Volume I: Compliance Plan Volume and Volume II: Background Volume. It was submitted in accordance with Section 2.3 of the Compliance Plan of the Site Treatment Plan. The highlights from the update included (1) the completion of treatment of reactives/oxidizers treatability group, (2) a summary of the progress and revisions to the treatment options and milestones for the organic sludge treatability group, (3) the update on the nitroaromatic soil treatment, and (4) information regarding the new treatability groups: Organic Liquids 2 and Selenium contaminated water.

RCRA groundwater monitoring for regulated units is discussed in detail in Chapter 8 .

\section{Clean Air Act}

CAA compliance requirements pertaining to the site are found in Title I - Nonattainments, Title III - Hazardous Air Pollutants (including National Emission Standards for Hazardous Air Pollutants (NESHAPS)) and Title VI - Stratospheric Ozone Protection. NESHAPs dose calculations for 1997 indicate the highest receptor activity was below the NESHAPs standard of $10 \mathrm{mrem}(0.1 \mathrm{mSv})$.

St. Charles County is classified in the Federal Register of November 6, 1991, 56 FR 215 as a moderate nonattainment area for ozone. As a moderate ozone nonattainment area, the requirements would affect sources emitting nitrogen oxides $\left(\mathrm{NO}_{\mathrm{x}}\right)$ and volatile organic compounds (VOCs). At present, these sources do not exist at the WSSRAP.

Under Title III, asbestos and radionuclides are hazardous air pollutants. These standards establish criteria for the control of radionuclide and asbestos emissions. WSSRAP programs for radionuclides and asbestos are described in detail in Sections 4 and 6, along with the 1997 status of monitoring.

\section{Clean Water Act}

Effluents discharged to waters of the United States are regulated under the Clean Water Act (CWA) through regulations promulgated and implemented by the State of Missouri. The Federal government has granted regulatory authority for implementation of CWA provisions to those states with a regulatory program that is at least as stringent as the Federal program.

Compliance with the CWA at the WSSRAP included meeting parameter limits set in four National Pollutant Discharge Elimination System (NPDES) permits. Under these permits, both effluent and erosion-control monitoring are performed. Section 7 includes additional details on the NPDES programs. 
Floodplain Management

The floodplain management Executive Order 119988, 10 CFR Part 1022 is applicable at the Southeast Drainage area, which lies in the Missouri River floodplain. A Floodplains Notice of Involvement was published in the Federal Register on April 16, 1997, and work has been completed in this area.

\section{Rivers and Harbors Act}

No work activity was conducted during this reporting period that would fall under the Act.

Federal Insecticide, Fungicide, and Rodenticide Act

The WSSRAP maintains compliance with the Federal Insecticide, Fungicide, and Rodenticide Act. Pesticide storage areas are routinely inspected. Material Safety Data Sheets are reviewed for all pesticides before they are purchased. The WSSRAP does not currently use restricted-use pesticides as they do not posses the proper permit/license to purchase these materials. The WSSRAP must also meet State requirements for pesticide application which outline specific licenses for specific uses of any pesticide. All applications are reviewed for State licensing requirements.

\section{Department of Transportation}

Pursuant to U.S. Department of Transportation (DOT) training requirements, the WSSRAP continues to conduct on-site training on hazardous material transportation. The training targets personnel with responsibilities for hazardous materials transportation. The training covers classification of hazardous materials by shipping names, performance based packaging requirements, requirements for marking, labeling and placarding, and proper segregation and modes of transportation. Retraining is required every 3 years.

\section{Safe Drinking Water Act}

Currently, the Safe Drinking Water Act (SDWA) is not an applicable and /or relevant and appropriate requirement at the WSSRAP. The SDWA is currently being evaluated for its applicability to the groundwater and Quarry Residuals Operable Units. 


\section{Emergency Planning and Community Right-to-Know Act}

The 1995 Emergency Planning and Community Right-to-Know Act (EPCRA) Tier II report was completed and provided on February 19,1997, to the local emergency planning committee (LEPC) and to the Missouri State Emergency Response Commission (MERC).

The Toxic Release Inventory (TRI) report was not required due to EPA changing hydrochloric acid to only aerosol forms, which the WSSRAP does not use.

\section{Cultural Resources/National Historic Preservation Act}

The annual Federal Archaeological report for 1996 was submitted on January 27, 1997.

In February 1997 the site sent a "no effect" letter for area identified as the Southeast Drainage. On March 17, 1997, the Missouri State Historic Preservation Office sent the site a response that they "are not entirely certain that a finding of "no effect" is appropriate..." at that time they requested an overview describing any agreements that may have been reached since the WSSRAP was initiated, due to significant turnover of staff including the Director.

In response to the request, a large map of the entire operation area was developed. Each area surveyed was identified by separate color coding.

A full Phase I survey of the Southeast Drainage was conducted by Argonne National Laboratory (ANL) in March and April 1997.

On August 25, 1997, a copy of the report was provided to the Missouri SHPO, along with a letter reiterating our "no effect" determination. The SHPO did not object to the determination, which is presumed concurrence, as specified in 36 CFR 800.

No further historic preservation activities took place in 1997.

\section{Endangered Species Act}

There was no activity this reporting period.

\section{Engineering Evaluation/Cost Analysis(EE/CA) for the Southeast Drainage}

The EE/CA for the Southeast Drainage (Ref.70) was completed in August 1996. Under the proposed action selected in the EE/CA, specific contaminated sediment in accessible areas of the drainage would be removed with track-mounted equipment and transported by off-road haul trucks. In November of 1996, the decision document for the removal action for the Southeast 
Drainage (INSIE 584) was finalized authorizing soil removal. The engineering design specifications and the post-remediation sampling plan were developed in 1997. These documents designated locations for soil removal, methods for excavation and areas where samples would be collected to provide data to assess risk reduction. Soil removal activities were completed in January 1998.

\subsubsection{DOE Order Compliance}

\subsubsection{DOE Order 5400.5, Radiation Protection of the Public and the Environment}

DOE Order 5400.5 establishes primary standards and requirements for DOE operations to protect members of the public and the environment against undue risk from radiation. The DOE operates its facilities and conducts its activities so that radiation exposures to members of the public are maintained within established limits.

The annual dose to the maximally exposed member of the public as a result of activities at the Weldon Spring site was below the $100 \mathrm{mrem}(1 \mathrm{mSv})$ guideline for all potential exposure modes. The $10 \mathrm{mrem}(0.1 \mathrm{mSv})$ annual dose limit for public exposure to airborne emissions, excluding radon and its respective decay products as specified in 40 CFR Part 61, National Emission Standards for Hazardous Air Pollutants, was not exceeded in 1997. The appropriate dose evaluation techniques were used to assess 1997 environmental monitoring and surveillance data in compliance with this requirement.

The annual average uranium concentrations at all NPDES outfalls were below the derived concentration guideline (DCG) of an annual average of $600 \mathrm{pCi} / \mathrm{l}(22.2 \mathrm{~Bq} / \mathrm{l})$.

Records of all environmental monitoring and surveillance activities conducted at the Weldon Spring site in 1997 are being maintained in accordance with the requirement of this order. All reports and records generated at the WSSRAP in 1997, pursuant to DOE order requirements, presented data in the units specified by the applicable regulation or order.

\subsubsection{DOE Order 5820.2A, Radioactive Waste Management}

DOE Order 5820.2A establishes policies, guidelines, and minimum requirements by which the DOE manages its radioactive and mixed waste and contaminated facilities. The Weldon Spring site was in compliance with the applicable portions of Chapter IV management of waste containing Area $11 \mathrm{e}(2)$ by-product material and naturally occurring and accelerator produced radioactive material, Chapter $\mathrm{V}$ (decommissioning of radioactively contaminated facilities), and Chapter VI (administrative activities related to the Waste Management Plan [Ref. 20]). The types of wastes addressed in Chapters I, II, and III of the Order were not present at the site. While the term "low level waste" is used in the FFCA site treatment plant abatement order, we 
expect to be able to clarify the definition of these wastes to reflect that they are by-product materials as defined by DOE Order 5820.2A

\subsubsection{DOE Order 5400.1, General Environmental Protection Program}

The WSSRAP conducted both radiological and nonradiological environmental monitoring programs at the site and vicinity properties. Environmental monitoring required by DOE Order 5400.1 was conducted to measure and monitor effluents and to provide surveillance of their effects on the environment and public health.

The WSSRAP was in compliance with Order 5400.1 requirements for preparation of an Environmental Protection Program Implementation Plan (EPPIP) (Ref.8). The EPPIP details programs in place at the WSSRAP to provide management direction, environmental protection goals and objectives, and the overall framework for the environmental protection program at the WSSRAP. The project has prepared an Environmental Monitoring Plan (Ref. 42) that is reviewed annually and revised as necessary.

In addition to the plans developed for overall environmental monitoring and protection, the WSSRAP annually reviews and revises, as necessary, the Groundwater Protection Program Management Plan (Ref. 13) and the Waste Minimization and Pollution Prevention Awareness Plan (Ref. 16). Refer to Section 2.6 for additional details.

\subsection{Current Issues and Actions}

\subsubsection{Current Issues}

\subsubsection{National Emission Standards for Hazardous Air Pollutants Compliance}

The WSSRAP has developed a critical receptor monitoring program for compliance with the requirements of 40 CFR 61 Subpart $H$. Point source and environmental monitoring have been mandated per 40 CFR 61.93(b)(5), whereby air concentrations are monitored at seven designated critical receptor locations on and around the Weldon Spring site. The WSSRAP plan is contained in the Plan for Monitoring Radionuclide Emissions Other Than Radon at Weldon Spring Site Critical Receptors (Ref. 21), which has been approved by the U.S. Environmental Protection Agency (EPA). The EPA has also approved the WSSRAP plan to report annual monitoring results and effective dose equivalents at critical receptor locations via the annual site environmental reports. 


\subsection{Summary of Permits for 1997}

Various permits were maintained by the WSSRAP for remedial activities including NPDES, excavation, and floodplain permits. Table 3-1 provides a summary of all NPDES permits. Four active NPDES permits covered discharges from the site water treatment plant (MO-01077701), quarry water treatment plant (MO-0108987), storm water discharges from the Borrow Area and Borrow Area haul road (MO-R100B69), and hydrostatic test water from the site (MO-G670203). An NPDES construction permit for the leachate collection removal system of the cell was issued in January 1997.

Table 3-1 Summary of WSSRAP NPDES and Construction Permits

\begin{tabular}{|l|c|c|c|c|l|l|}
\hline PERMIT NO. & (a) & $\begin{array}{c}\text { DATE } \\
\text { ISSUED }\end{array}$ & $\begin{array}{c}\text { DATE } \\
\text { EXPIRED }\end{array}$ & (b) & $\begin{array}{c}\text { DATE RENEWAL } \\
\text { OR EXTENSION } \\
\text { REQUEST DUE }\end{array}$ & \multicolumn{1}{c|}{ SCOPE AND COMMENTS } \\
\hline MO-0107701 & 0 & $03 / 03 / 94$ & $03 / 04 / 99$ & $\mathrm{~N}$ & $09 / 04 / 98$ & $\begin{array}{l}\text { Covers storm water, sanitary, and } \\
\text { SWTP discharges. }\end{array}$ \\
\hline MO-0108987 & 0 & $06 / 09 / 94$ & $06 / 10 / 99$ & $\mathrm{Y}$ & $01 / 10 / 99$ & Covers QWTP discharge. \\
\hline MO-R100869 & 0 & $09 / 01 / 94$ & $06 / 11 / 97$ & $\mathrm{Y}$ & $12 / 11 / 96$ & $\begin{array}{l}\text { Storm water discharges from the } \\
\text { Borrow Area and haul road operations. }\end{array}$ \\
\hline MO-G670203 & 0 & $12 / 05 / 97$ & $10 / 23 / 02$ & $\mathrm{~N}$ & $02 / 23 / 02$ & Covers hydrostatic test water at site. \\
\hline MO-22-5186 & $\mathrm{C}$ & $01 / 08 / 97$ & $01 / 07 / 02$ & $\mathrm{~N}$ & $12 / 07 / 01$ & $\begin{array}{l}\text { Covers construction of cell leachate } \\
\text { collection system. }\end{array}$ \\
\hline
\end{tabular}

(a) Permit type, $\mathrm{O}=$ Operating, $\mathrm{C}=$ Construction

(b) Permit removal application submitted $N=$ No, $Y=Y e s$.

QWTP Quarry water treatment plant

SWTP Site water treatment plant.

\subsection{Site Mitigation Action Plan}

The progress of the mitigative actions for the remediation of the Weldon Spring site is reported annually in the site environmental report in accordance with DOE Order 5440.1E. The Mitigation Action Plan (MAP) for the Remedial Action at the Chemical Plant Area of the Weldon Spring Site (Ref. 18), was developed to present mitigation actions planned in order to provide protection for human health and the environment during remedation activities. The MAP is reviewed and updated annually, as necessary, to reflect site conditions.

Construction activities at the Weldon Spring site are managed by using good engineering practices for control of surface water runoff at, and from, the site. During 1997, four sedimentation basins and two retention ponds were in place at the chemical plant area during soil excavation activities. Surface water protection during 1997 included erosion prevention and sediment control and monitoring. Monitoring was conducted at four outfall locations at the chemical plant, and the requirements of three NPDES permits and the Missouri Clean Water Act were met during 1997. Further information on compliance issues are provided in Section 7. 
The wetlands mitigation agreement with the Corps of Engineer (COE) was signed in 1994 to establish a replacement wetland area. Remedial activities at the site have eliminated some wetlands during 1997. The construction of the replacement wetland area was completed in August 1997 at the Busch Memorial Conservation Area in accordance with the mitigation plan. Wetlands monitoring was conducted by the DOE at the mitigation area in 1997. The results of the first year's monitoring is reported in the 1997 Wetlands Monitoring Report for the Weldon Spring Site Remedial Action Report (Ref. 77).

Topsoils and subsoils from the Borrow Area that are being stored for restoration have been stockpiled at the Borrow Area. Stockpile heights and slopes have been limited to 2.5:1 and stockpiles have been seeded and mulched to control erosion. In 1997, 60 acres at the Borrow Area have been reclamated and seeded with a top seed mix. Erosion control measures are implemented at the Borrow Area and the haul road. Stockpiles are routinely inspected for erosion. Two sedimentation ponds have been constructed at the Borrow Area, and surface water has been monitored to measure the effective removal of settleable materials. Specific NPDES compliance details for the Borrow Area are provided in Section 7.

During the development of the Borrow Area in 1996, vehicle and equipment noise levels were monitored to ensure that nuisance noise levels remained at acceptable levels. Roadways were sprayed with water on an as-needed basis for dust control during the active construction periods at the Borrow Area.

Air, surface water, and groundwater have been monitored as part of the routine environmental activities at the chemical plant area. Results of that monitoring are detailed extensively in this report.

Eligibility surveys for archeological or historic sites were conducted on the $30.5 \mathrm{~m}(100 \mathrm{ft})$ site perimeter around the chemical plant site, and no sites were found that would require avoidance or data recovery. Confirmation letters in regard to this decision have been received by the State Historic Preservation Officer. 


\section{AIR MONITORING PROGRAMS}

The Weldon Spring Site Remedial Action Project (WSSRAP) operates its environmental airborne monitoring and surveillance program in accordance with U.S. Department of Energy (DOE) Orders and with the Environmental Monitoring Plan (Ref. 42). This section describes monitoring results for radon, gamma exposure, airborne radioactive particulates, and airborne asbestos at various site perimeter and off-site locations. A program overview, summary of applicable standards, actual monitoring results, and an assessment of any associated environmental impacts are provided below for each parameter mentioned in the plan.

\subsection{Highlights of Air Monitoring}

- Statistical analysis at the $95 \%$ confidence level indicated that three integrated radon track etch monitoring stations along the chemical plant perimeter and nine stations in the raffinate pits area (within the site boundary) exceeded annual average background levels in 1997. No annual integrated radon track etch results at critical receptor locations were statistically greater than background levels. The highest above background integrated radon concentration along the site perimeter was $47 \%$ of the derived concentration guide (DCG) for radon occurring at Station RD-3001 (northwest of Raffinate Pit 4).

- Statistical analysis at the $95 \%$ confidence level indicated that seven modified Rn-220 track etch monitoring locations exceeded 1997 average background levels, including one at the quarry, three along the chemical plant perimeter, and three in the raffinate pits area within the site boundary. The highest above background $\mathrm{Rn}-220$ concentration along the site perimeter was $63 \%$ of the derived concentration guide (DCG) for Rn-220, occurring at Station RD-3001 (northwest of Raffinate Pit 4).

- Environmental thermoluminescent dosimeter (TLD) results for 1997 at the chemical plant perimeter, quarry perimeter, and off-site locations ranged from 52 mrem/year $(0.52 \mathrm{mSv} /$ year $)$ to $119 \mathrm{mrem} /$ year $(1.19 \mathrm{mSv} /$ year $)$. These results are inclusive of background levels, which totaled $59 \mathrm{mrem}(0.59 \mathrm{mSv})$ for the year. Statistical analysis of the results indicate that at the $95 \%$ confidence level six chemical plant/raffinate pit area stations exceeded background levels. These six stations exceeded background levels by $10 \mathrm{mrem}(0.1 \mathrm{mSv})$ to $60 \mathrm{mrem}(0.6 \mathrm{mSv})$.

- Statistical analysis at the $95 \%$ confidence level indicated that four low-volume airborne particulate monitoring stations along the chemical plant perimeter had annual average concentrations that exceeded background levels. These four stations exceeded the 104-week background average by $1.9 \mathrm{E}-16 \mu \mathrm{Ci} / \mathrm{ml}(7.03 \mathrm{E}-12 \mathrm{~Bq} / \mathrm{ml})$ to $6.2 \mathrm{E}-16 \mu \mathrm{Ci} / \mathrm{ml}$ (2.29E-11 Bq/ml). 
- All 1997 air monitoring results at Francis Howell High School (including radon, gamma exposure, and airborne radioactive particulates) were indistinguishable from background.

\subsection{Radon Gas Monitoring Program}

\subsubsection{Program Overview}

Both U-238 and Th-232 are naturally occurring radionuclides in soil and rock. Radon gases (i.e., Rn-222, radon, and Rn-220, thoron) are naturally occurring radioactive gases found in the U-238 and Th-232 decay series, respectively. A fraction of the radon produced from the radioactive decay of U-238 and Th-232 diffuses from soil and rock into the atmosphere, accounting for natural background airborne radon concentrations. Radon and thoron gases are produced at the Weldon Spring site from these natural sources as well as from the contaminated waste materials present at the site.

Airborne radon and thoron concentrations are governed by source strength and dilution factors, both of which are strongly affected by meteorological conditions. The soil surface constitutes the largest source of radon and thoron, although secondary contributors include oceans, natural gas, geothermal fluids, volcanic gases, ventilation from caves and mines, and coal combustion. Radon and thoron levels in the atmosphere have been observed to vary with height above the ground, season, time of day, and location. The chief meteorological parameter governing airborne radon and thoron concentrations is atmospheric stability; however, the largest variations in atmospheric radon and thoron occur spatially (Ref. 73 ).

Two types of track etch detectors are used at the WSSRAP to measure ambient levels of radon gas: standard "F-type" detectors, which measure a combination of radon and thoron gas (results are termed "integrated"), and modified "M-type" detectors, which indirectly indicate ambient levels of thoron only. F-type and M-type track etch detectors are used in conjunction to distinguish radon and thoron concentrations by analyzing the relative response of paired sets of these detectors at each monitoring location where they are deployed.

In 1997, a pair of standard F-type track etch detectors was deployed at each of 28 permanent monitoring locations: five at the Weldon Spring Chemical Plant perimeter, two at the Weldon Spring Quarry perimeter, 14 at the raffinate pits area, and seven at off-site locations. Track etch monitoring locations are identified with an "RD" prefix and are shown in Figures 4-1, 4-2, 4-3, and 4-4. Monitoring locations are distributed around the chemical plant, raffinate pits, and quarry perimeters to ensure adequate detection of radon and thoron under varying meteorological conditions. Locations RD-4005 and RD-4009 monitor background radon and thoron concentrations. F-type track etch detectors are sensitive to all isotopes of radon and are deployed quarterly. 


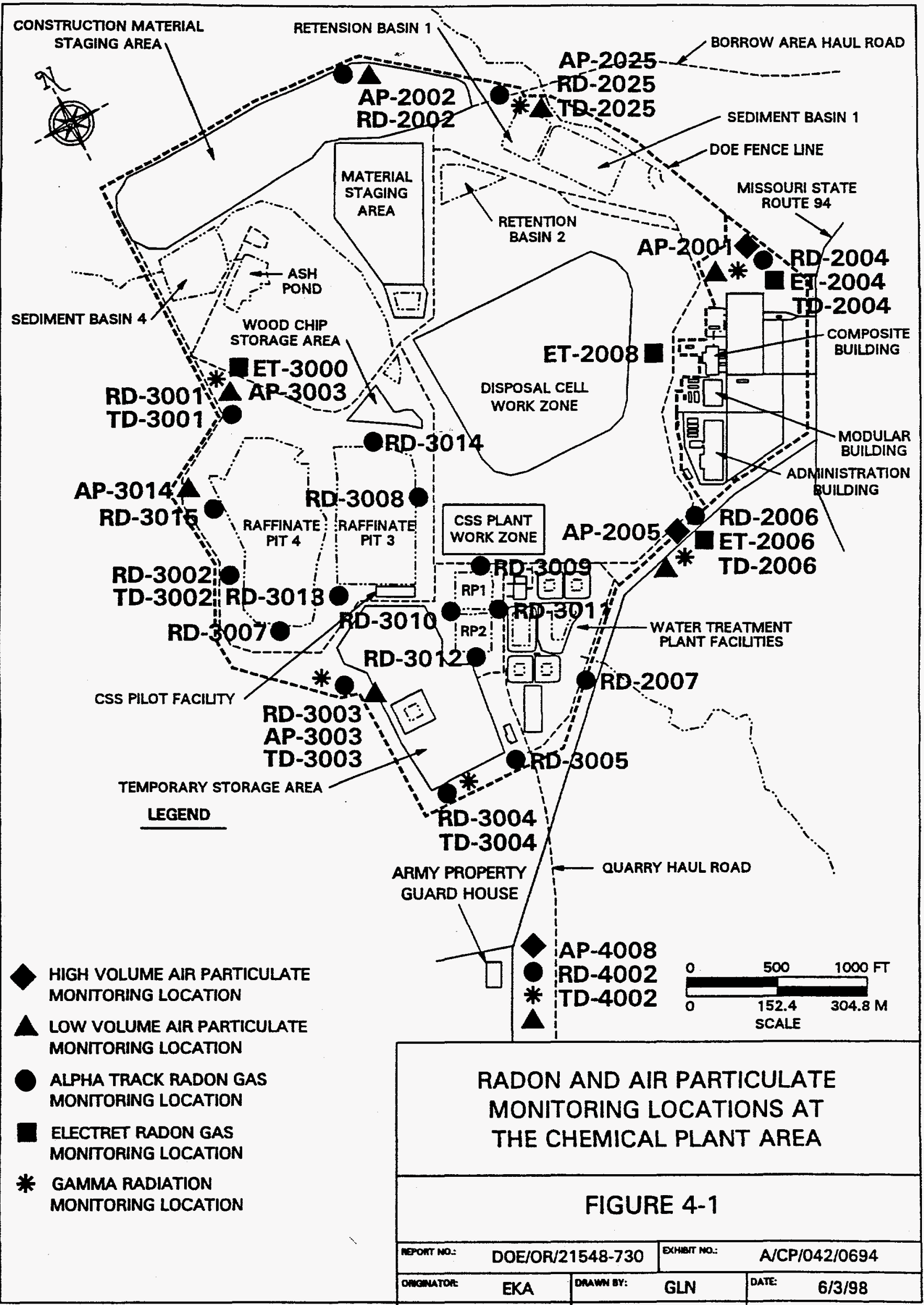




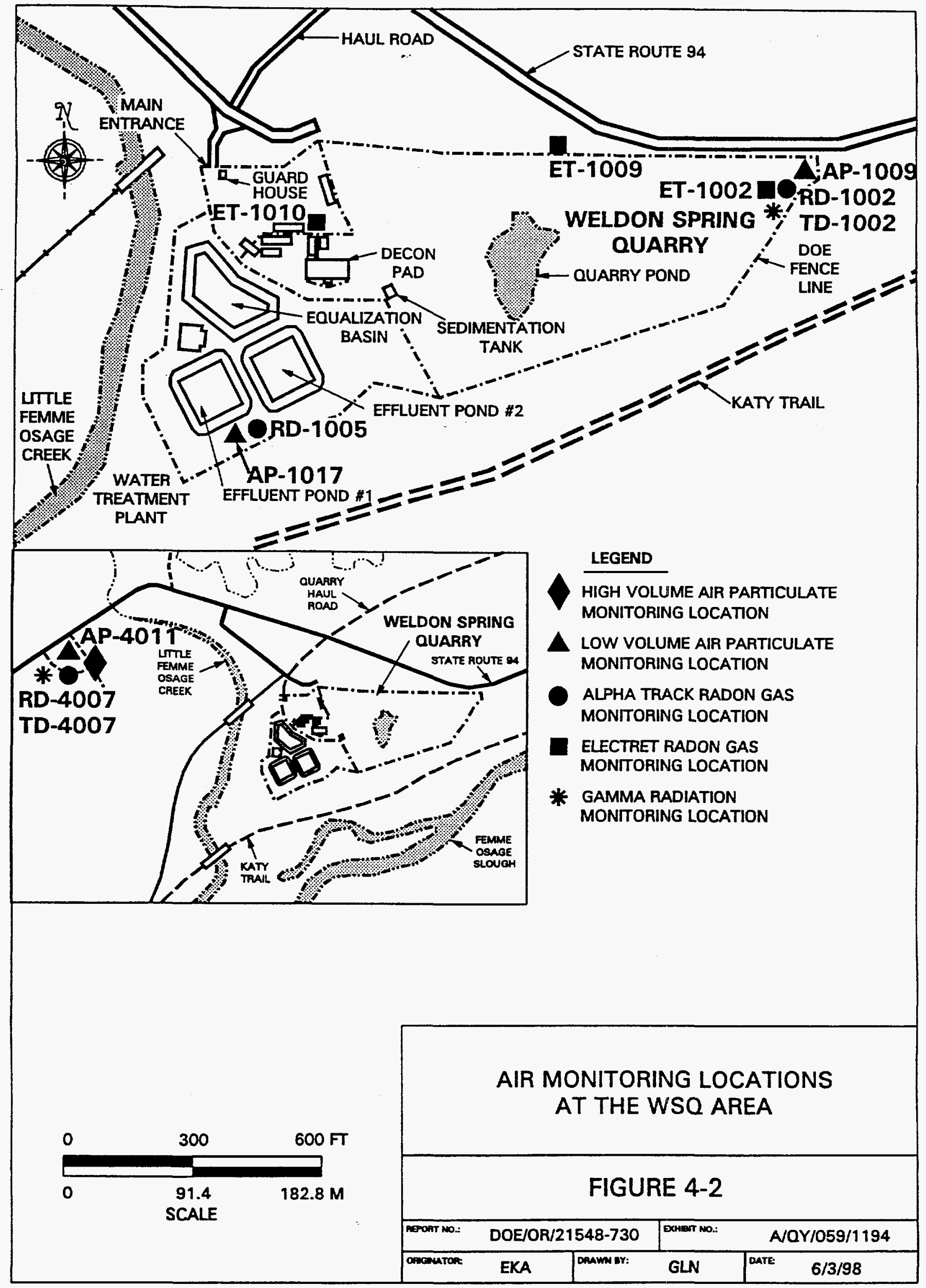




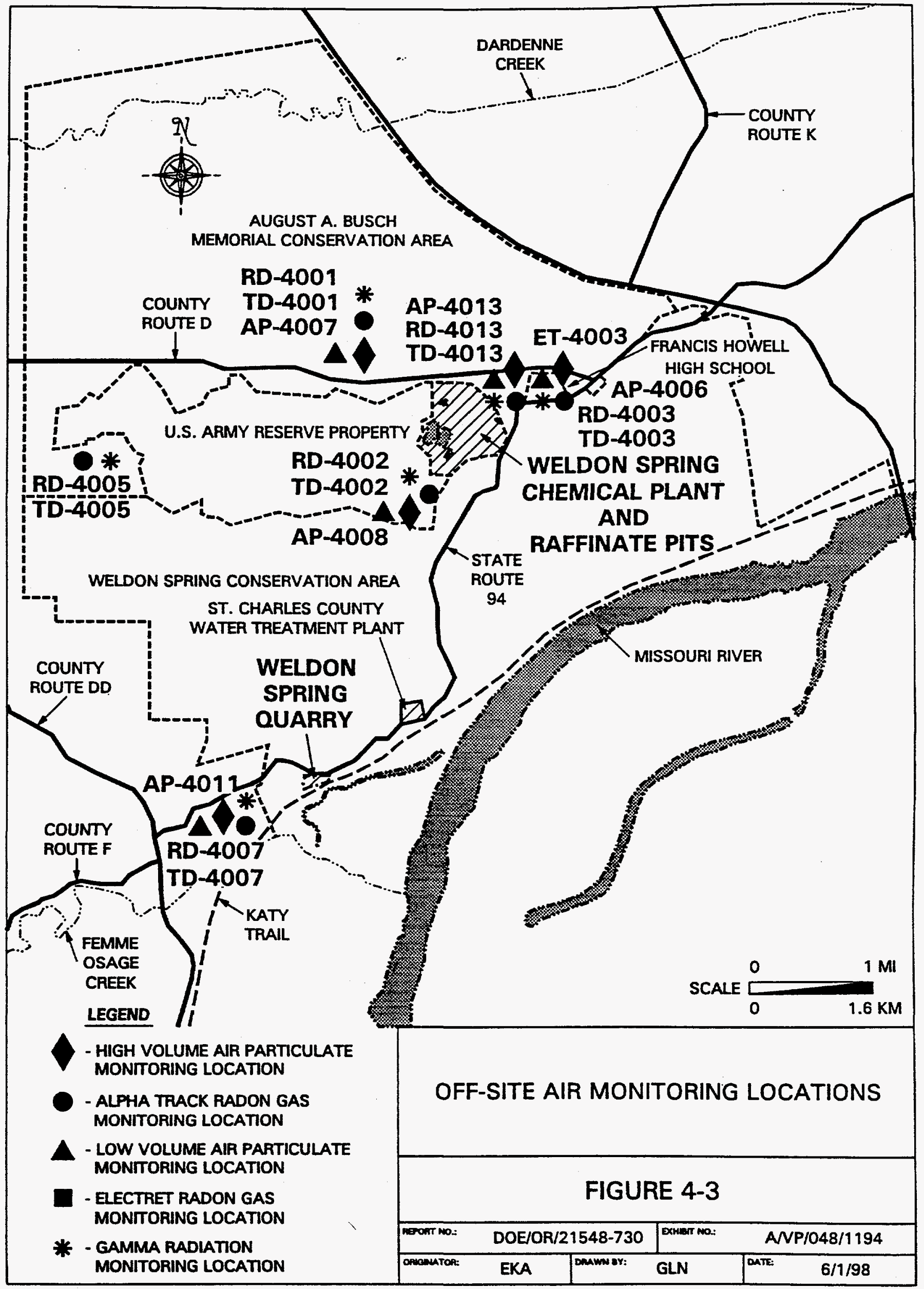




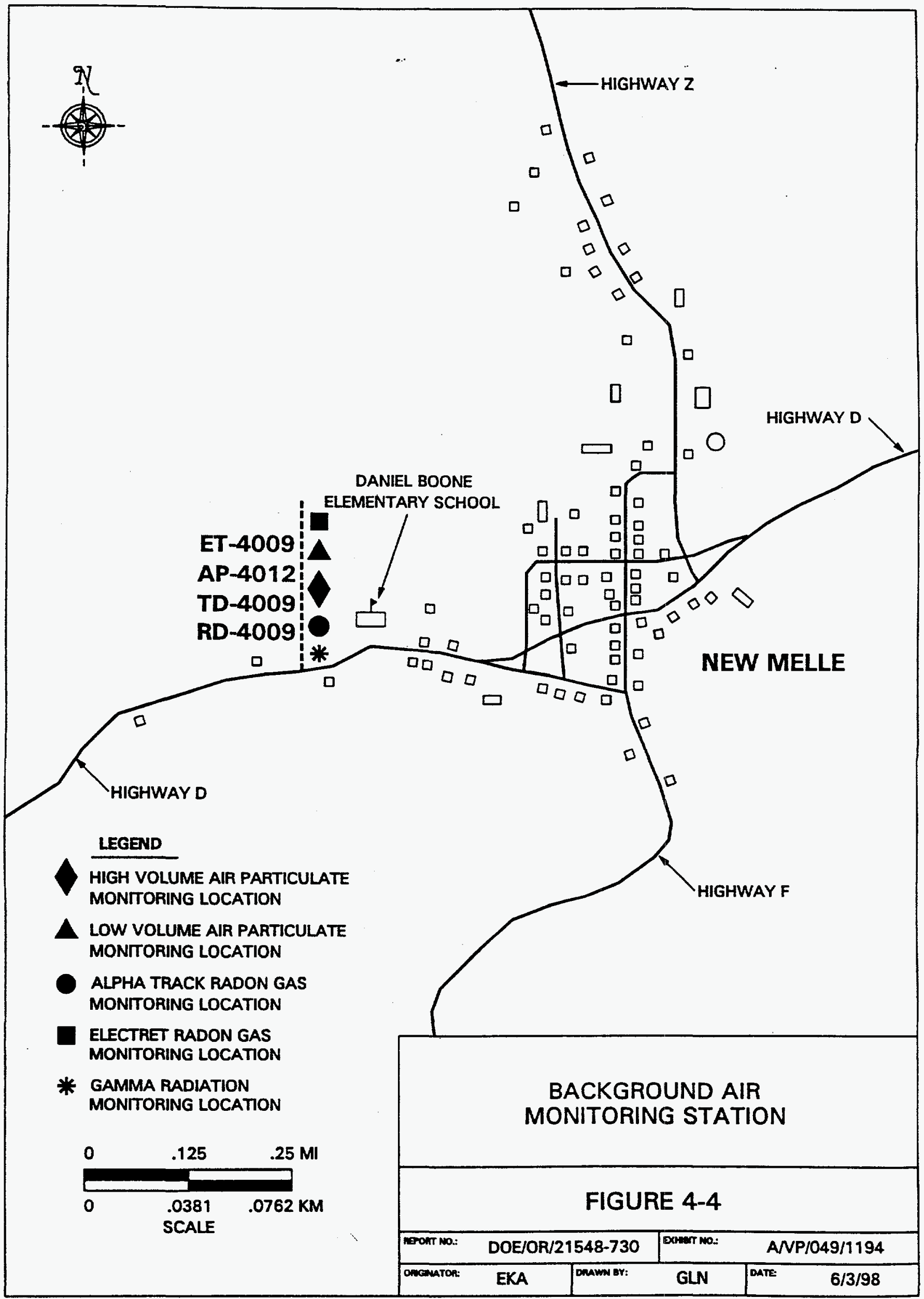


Paired M-type alpha etch detectors were deployed in 1997 at 21 monitoring locations: five at the chemical plant perimeter, one at the quarry perimeter, eight at the raffinate pits area, and seven at off-site locations (including two background locations, RD-4005 and RD-4009).

Specific locations are identified on Figures 4-1 through 4-4. These detectors were placed in conjunction with F-type track etch detectors to distinguish radon from thoron concentrations. Using Pearson's method (Ref. 49), separate concentrations of radon and thoron were calculated for these stations.

The WSSRAP radon monitoring program also uses electret detectors, which provide more timely data (biweekly) than the track etch detectors. Like track etch detectors, electret detectors provide a passive means of measuring radon and thoron gas concentrations in air. Twenty-eight pairs of electret detectors that measure Rn-222 only were placed at the following monitoring locations: 23 in the chemical plant and raffinate pits area (including three along the chemical plant perimeter), three at the quarry perimeter, and two off site. Fifteen pairs of electrets that indicate $\mathrm{Rn}-220$ concentration were deployed at the following locations: 11 in the vicinity of the raffinate pits and temporary storage area (TSA), two at the quarry perimeter, and two off site (including one background location, ET-4009). Electrets are exchanged and read biweekly. These locations, designated by an "ET" prefix, are shown in Figures 4-1 through 4-5.

Continuous radon gas monitors and working level monitors (which measure radon daughters in the air) complete the environmental radon monitoring network. Continuous radon gas monitors are sensitive to both $\mathrm{Rn}-222$ and $\mathrm{Rn}-220$. A continuous radon gas monitor was placed at critical receptor monitoring station AP-2001, near the Missouri Highway and Transportation Department facility during the fall of 1997. Other monitors were placed in on-site work zones throughout the year to evaluate local airborne levels of $\mathrm{Rn}-222$ and $\mathrm{Rn}-220$ present as a result of remediation activities. On-site locations included the raffinate pits and TSA.

Working level monitors are sensitive to the short-lived decay products of $\mathrm{Rn}-220$ and $\mathrm{Rn}-222$. Results are recorded in milli-working levels ( $\mathrm{mWL}$ ). Working level monitors are used in work zones in conjunction with continuous radon gas monitors to determine the degree of equilibrium of radon (or thoron) gas with its decay products and the potential radon or thoron progeny dose to workers. The working level monitors operated in 1997 at the raffinate pits during periods of remedial action work.

\subsubsection{Applicable Standards}

As established by DOE Order 5400.5 , the DOE annual public dose equivalent limit is $100 \mathrm{mrem}(1 \mathrm{mSv})$ total effective dose equivalent (TEDE).

DOE/OR/21548-730, Rev. 0 


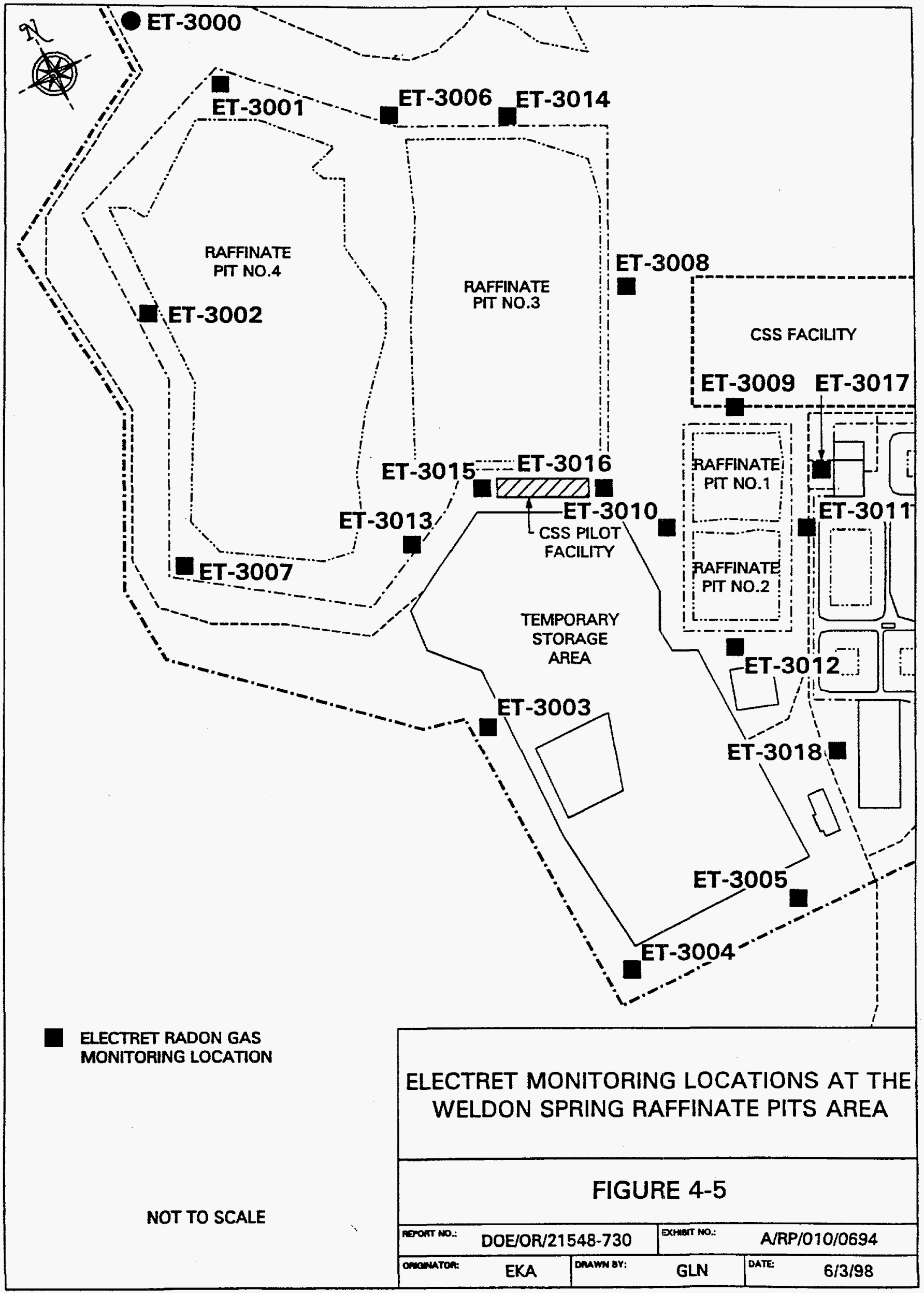


Dose limits for the inhalation of radon and thoron progeny and gas, are based on working levels and concentrations in air, and are addressed independently in the Order. The DCG, which is a limiting airborne concentration of a specified radionuclide, is specified by DOE 5400.5 to be $3 \mathrm{pCi} / \mathrm{l}\left(100 \mathrm{~Bq} / \mathrm{m}^{3}\right)$ above background for both radon and thoron in unrestricted (off-site) areas.

\subsubsection{Monitoring Results}

Table 4-1 summarizes quarterly and annual average integrated radon concentrations as measured by F-type track etch detectors. Since radon is naturally occurring, concentrations measured at each monitoring location were compared to measured background concentrations to determine whether any significant differences existed at the $95 \%$ confidence level. Only perimeter locations with integrated radon concentrations statistically greater than background were compared to the DCG for radon by subtracting the average annual background concentration from the gross annual average concentration measured at a given location.

The results obtained from the pair of F-type track etch detectors at each location were averaged to determine the quarterly average integrated radon concentration. These averages were then used to calculate the annual average integrated radon concentration. The annual standard deviation reported reflects the error propagated by taking the sample standard deviation of the mean of each of the quarterly results.

The annual F-type track etch background concentration was calculated using the arithmetic average of the two background locations. The data yielded an annual background average integrated radon concentration in 1997 of $0.2 \mathrm{pCi} / 1\left(7.4 \mathrm{~Bq} / \mathrm{m}^{3}\right)$. This result is consistent with previous years' monitoring results.

Based on measurements from F-type and M-type track etch detectors at locations where a combined release of $R n-222$ and $R n-220$ was suspected, $R n-220$ concentrations were estimated using Pearson's method (Ref. 49). Locations with $\mathrm{Rn}-220$ concentrations statistically greater than background at the $95 \%$ confidence level were compared with the DCG for thoron. Results are presented in Table 4-2.

The annual Rn-220 background concentration was determined to be $0.1 \mathrm{pCi} / 1\left(4 \mathrm{~Bq} / \mathrm{m}^{3}\right)$ and was calculated using the arithmetic average of the two background locations. This result is consistent with previous years' monitoring results.

DOE/OR/21548-730, Rev. 0 
Table 4-1 1997 Track Etch Integrated Radon Results ${ }^{(a)}$

\begin{tabular}{|c|c|c|c|c|c|c|c|c|}
\hline $\begin{array}{l}\text { LOCATION } \\
\text { ID }\end{array}$ & $\begin{array}{l}\text { 1ST } \\
\text { QUARTER } \\
{\mathrm{pCi} / \mathrm{f}^{(b)}}^{(b)}\end{array}$ & $\begin{array}{l}\text { 2ND } \\
\text { QUARTER } \\
p C i / /^{(b)}\end{array}$ & $\begin{array}{l}\text { 3RD } \\
\text { QUARTER } \\
\text { pCi//(b) }\end{array}$ & $\begin{array}{l}\text { 4TH } \\
\text { QUARTER } \\
\text { pCi// }{ }^{(b)}\end{array}$ & $\begin{array}{l}\text { ANNUAL } \\
\text { AVERAGE } \\
\text { pCi//(b) }\end{array}$ & $\begin{array}{l}\text { ANNUAL } \\
\text { STANDARD } \\
\text { DEVIATION }\end{array}$ & $\begin{array}{l}\text { STATISTICALLY } \\
\text { SIGNIFICANT }{ }^{(c)}\end{array}$ & $\begin{array}{l}\text { PERCENT OF } \\
\text { GUIDELINE' }\end{array}$ \\
\hline \multicolumn{9}{|c|}{ WELDON SPRING QUARRY } \\
\hline $\mathrm{RD}-1002$ & 0.5 & 0.3 & 0.1 & 0.4 & 0.3 & 0.17 & & N/A \\
\hline RD-1005 & 0.4 & 0.2 & 0.1 & 0.4 & 0.3 & 0.15 & & N/A \\
\hline \multicolumn{9}{|c|}{ WELDON SPRING CHEMICAL PLANT } \\
\hline RD-2002 & 0.4 & 0.2 & 0.1 & 0.4 & 0.3 & 0.15 & & N/A \\
\hline RD-2004 & 0.3 & 0.4 & 0.2 & 0.3 & 0.3 & 0.08 & & $N / A$ \\
\hline RD-2006 & 0.3 & 0.3 & 0.1 & 0.3 & 0.3 & 0.05 & & $\mathrm{~N} / \mathrm{A}$ \\
\hline RD-2007 & 0.3 & 0.2 & 0.1 & 0.5 & 0.3 & 0.17 & & N/A \\
\hline RD-2025 & 0.3 & 0.4 & 0.2 & 0.4 & 0.3 & 0.14 & & N/A \\
\hline \multicolumn{9}{|c|}{ WELDON SPRING RAFFINATE PITS } \\
\hline RD-3001 & 1.7 & 3.2 & 0.7 & 0.7 & 1.6 & 1.18 & $\mathrm{X}$ & 47 \\
\hline $\mathrm{RD}-3002$ & 0.8 & 1.1 & 0.6 & 0.7 & 0.8 & 0.22 & $\mathrm{X}$ & 20 \\
\hline RD-3003 & 0.5 & 0.7 & 0.8 & 1.0 & 0.8 & 0.21 & $\mathrm{X}$ & 20 \\
\hline RD-3004 & 0.3 & 0.4 & 0.1 & 0.4 & 0.3 & 0.14 & & N/A \\
\hline RD-3005 & 0.3 & 0.3 & 0.1 & 0.5 & 0.3 & 0.16 & & N/A \\
\hline RD-3007 & 1.0 & 2.7 & 14.7 & 6.5 & 6.2 & 6.1 & $x$ & $N / A^{(1)}$ \\
\hline$R D-3008$ & 0.7 & 1.4 & 1.5 & 0.7 & 1.1 & 0.43 & $x$ & $N / A^{(1)}$ \\
\hline RD-3009 & 0.5 & 0.5 & 0.2 & 0.5 & 0.4 & 0.15 & $x$ & $N / A^{(1)}$ \\
\hline RD-3010 & 1.8 & 1.1 & 1.0 & 2.4 & 1.6 & 0.66 & $x$ & $N / A^{(1)}$ \\
\hline RD-3011 & 0.9 & 0.8 & 0.2 & 0.6 & 0.6 & 0.31 & $x$ & $N / A^{(1)}$ \\
\hline RD-3012 & 0.6 & 0.6 & 0.4 & 1.0 & 0.7 & 0.25 & $x$ & $N / A^{(1)}$ \\
\hline RD-3013 & 2.0 & 3.0 & 3.3 & 2.3 & 2.7 & 0.60 & $x$ & $N / A^{(1)}$ \\
\hline RD-3014 & 4.3 & 7.0 & 2.2 & 1.0 & 3.6 & 2.6 & $x$ & $N / A^{(i)}$ \\
\hline RD-3015 & 4.1 & 6.2 & 1.8 & 0.9 & 3.3 & 2.4 & $x$ & $N / A^{(1)}$ \\
\hline \multicolumn{9}{|c|}{ OFF SITE } \\
\hline RD-4001 & 0.2 & 0.2 & 0.1 & 0.3 & 0.2 & 0.08 & & $\mathrm{~N} / \mathrm{A}$ \\
\hline RD-4002 & 0.2 & 0.2 & 0.1 & 0.2 & 0.2 & 0.05 & & N/A \\
\hline RD-4003 & 0.1 & 0.1 & 0.2 & 0.2 & 0.2 & 0.06 & & N/A \\
\hline${ }^{*} \mathrm{RD}-4005$ & 0.3 & 0.1 & 0.1 & 0.4 & 0.2 & 0.15 & & N/A \\
\hline
\end{tabular}




\begin{tabular}{|c|c|c|c|c|c|c|c|c|}
\hline $\begin{array}{l}\text { LOCATION } \\
\text { ID }\end{array}$ & $\begin{array}{l}\text { 1ST } \\
\text { QUARTER } \\
\text { pCi/R }^{(b)}\end{array}$ & $\begin{array}{l}\text { 2ND } \\
\text { QUARTER } \\
p_{C i / /^{(b)}}\end{array}$ & $\begin{array}{l}\text { 3RD } \\
\text { QUARTER } \\
\text { pCi//(b) }\end{array}$ & $\begin{array}{l}\text { 4TH } \\
\text { QUARTER } \\
\text { pCi// }{ }^{(b)}\end{array}$ & $\begin{array}{l}\text { ANNUAL } \\
\text { AVERAGE } \\
\text { pCi// }{ }^{(b)}\end{array}$ & $\begin{array}{l}\text { ANNUAL } \\
\text { STANDARD } \\
\text { DEVIATION }\end{array}$ & $\begin{array}{l}\text { STATISTICALLY } \\
\text { SIGNIFICANT }\end{array}$ & $\begin{array}{l}\text { PERCENT OF } \\
\text { GUIDELINE }^{(d)}\end{array}$ \\
\hline RD-4007 & 0.2 & 0.1 & 0.1 & 0.4 & 0.2 & 0.14 & & N/A \\
\hline${ }^{*} \mathrm{RD}-4009$ & 0.2 & 0.2 & 0.1 & 0.4 & 0.2 & 0.13 & & N/A \\
\hline RD-4013 ${ }^{(g)}$ & $F$ & - & 0.5 & 0.2 & 0.4 & 0.21 & & \\
\hline
\end{tabular}

(a) Results include natural background levels except where otherwise noted.

(b) To convert from $\mathrm{pCi} / \mathrm{l}$ to $\mathrm{Bq} / \mathrm{m}^{3}$, multiply by 37 .

(c) Statistical significance is determined by comparing the annual average concentration for a monitoring location with the annual background average concentration, using a one-tailed Student's t-test at the $95 \%$ confidence level.

(d) Percent of guideline is calculated by taking the annual station average minus the average of the background stations, divided by the DOE concentration guideline for $\mathrm{Rn}-222$ of $3 \mathrm{pCi} / \mathrm{l}\left(100 \mathrm{~Bq} / \mathrm{m}^{\wedge} 3\right)$ annual average above background for uncontrolled areas

(e) Missing detectors.

(f) No percentage calculation performed for above-background monitoring locations within the site boundary.

(g) New critical receptor monitoring location.

* Background station.

N/A No percentage calculation performed for background locations or locations not statistically greater than background.

- $\quad$ No measurement taken. 
Table 4-2 1997 Thoron Concentrations as Determined Using Paired F-type and M-type Track Etch Detectors ${ }^{(\mathrm{a})}$

\begin{tabular}{|c|c|c|c|c|c|c|c|c|}
\hline STATION ID & $\begin{array}{c}\text { FIRST QUARTER } \\
(\mathrm{pCi} / \mathrm{I})^{(\mathrm{b})}\end{array}$ & $\begin{array}{l}\text { SECOND } \\
\text { QUARTER } \\
(\mathrm{pCi} /)^{(\mathrm{b})}\end{array}$ & $\begin{array}{c}\text { THIRD QUARTER } \\
(\mathrm{pCi} / 1)^{(\mathrm{b})}\end{array}$ & $\begin{array}{l}\text { FOURTH } \\
\text { QUARTER } \\
(\mathrm{pCl} /)^{(b)}\end{array}$ & $\begin{array}{l}\text { ANNUAL } \\
\text { AVERAGE } \\
\text { (pCi/l) }\end{array}$ & $\begin{array}{l}\text { ANNUAL } \\
\text { STANDARD } \\
\text { DEVIATION }\end{array}$ & $\begin{array}{r}\text { STATISTICALLV } \\
\text { SIGNIFICANT }(x)^{c}\end{array}$ & $\begin{array}{l}\text { PERCENT OF } \\
\text { GUIDELINE }^{\text {dd }}\end{array}$ \\
\hline \multicolumn{9}{|c|}{ Weldon Spring Quarry } \\
\hline RD-1002 & 0.2 & 0.3 & 0.1 & 0.3 & 0.2 & 0.10 & $\bar{x}$ & 3 \\
\hline \multicolumn{9}{|c|}{ Weldon Spring Chemical Plant } \\
\hline RD-2002 & 0.0 & 0.3 & 0.0 & 0.3 & 0.2 & 0.17 & & N/A \\
\hline RD-2004 & 0.0 & 0.4 & 0.3 & 0.2 & 0.2 & 0.17 & & N/A \\
\hline RD-2006 & 0.0 & 0.3 & 0.1 & 0.0 & 0.1 & 0.14 & & N/A \\
\hline RD-2007 & 0.0 & 0.1 & 0.0 & 0.3 & 0.1 & 0.14 & & N/A \\
\hline RD-2025 & 0.0 & 0.3 & 0.2 & 0.3 & 0.2 & 0.14 & & N/A \\
\hline \multicolumn{9}{|c|}{ Weldon Spring Raffinate Pits } \\
\hline RD-3001 & 2.4 & 3.9 & 1.1 & 0.6 & 2.0 & 1.48 & $x$ & 63 \\
\hline$R D-3002$ & 0.6 & 1.3 & 0.8 & 0.3 & 0.8 & 0.42 & $x$ & 23 \\
\hline RD-3003 & 0.0 & 0.9 & 1.2 & 1.1 & 0.8 & 0.55 & $x$ & 23 \\
\hline RD-3004 & 0.0 & 0.6 & 0.0 & 0.2 & 0.2 & 0.28 & & N/A \\
\hline RD-3005 & 0.0 & 0.4 & 0.1 & -- & 0.2 & 0.21 & & N/A \\
\hline RD-3007 & - & -- & 20.0 & 7.9 & 14.0 & 8.56 & X & $N / A^{(e)}$ \\
\hline $\mathrm{RD}-3010$ & 1.9 & 1.2 & 1.0 & 2.5 & 1.7 & 0.69 & $x$ & $N / A^{(e)}$ \\
\hline RD-3014 & 5.3 & 8.7 & 2.7 & 0.3 & 4.3 & 3.60 & $x$ & $N / A^{(e)}$ \\
\hline \multicolumn{9}{|c|}{ Off-Site } \\
\hline RD-4001 & 0.0 & 0.2 & 0.0 & 0.2 & 0.1 & 0.12 & & N/A \\
\hline RD-4002 & 0.0 & 0.1 & 0.0 & 0.0 & 0.0 & 0.05 & & N/A \\
\hline RD-4003 & 0.0 & 0.0 & 0.4 & 0.0 & 0.1 & 0.20 & & N/A \\
\hline $\mathrm{RD}-4005^{\star}$ & 0.1 & 0.2 & 0.1 & 0.0 & 0.1 & 0.08 & & N/A \\
\hline RD-4007 & 0.0 & 0.0 & 0.0 & 0.2 & 0.1 & 0.10 & & N/A \\
\hline RD-4009* & 0.0 & 0.2 & 0.0 & 0.2 & 0.1 & 0.12 & & N/A \\
\hline $\mathrm{RD}-4013$ & -- & - & 0.3 & 0.1 & 0.2 & 0.14 & & \\
\hline
\end{tabular}

* Background station

(a) Results include natural background levels

(b) To convert from $\mathrm{pCi} / \mathrm{l}$ to $\mathrm{Bq} / \mathrm{m}^{3}$, multiply by 37 .

(c) Statistical significance is determined by comparing the annual average concentration for a monitoring location with the annual average background concentration, using a one-tailed Student's t-test at the $95 \%$ confidence level.

Table 4-2 1997 Thoron Concentrations as Determined Using Paired F-type and M-type Track Etch Detectors ${ }^{\text {(a) }}$ (Continued) 


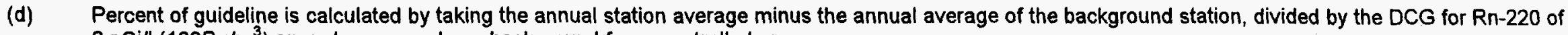
$3 \mathrm{pCi} / \mathrm{l}\left(100 \mathrm{~Bq} / \mathrm{m}^{3}\right)$ annual average above background for uncontrolled areas.

(e) No percentage calculation performed for above-background monitoring locations within site boundary

N/A No percent of guideline calculated fobackground stations or stations not statistically greater than background

-- Discontinued or new monitoring location; no data for this quarter. 
Although results in Tables 4-1 and 4-2 may appear inconsistent for a given monitoring location, this is to be expected since F-type detectors have a higher response function for $\mathrm{Rn}-222$ than for Rn-220. The supplemental thoron measuring technique using the M-type detectors provides a better estimate of the thoron contribution to the total radon concentration. Therefore, for monitoring stations where virtually all of the integrated radon concentration is contributed by thoron (for example, see results for RD-3001 and RD-3007, Tables 4-1 and 4-2), the thoron results using Pearson's method are larger than the respective integrated results.

Radon concentrations measured by the electret monitors are summarized in Tables 4-3 and 4-4. Because electret results are obtained biweekly rather than quarterly (as with the track etch detectors), they are used primarily as advance indicators of trends in radon/thoron levels at a given monitoring location. Therefore, track etch results, rather than electret results, are used in performing off-site dose calculations.

Historical average background concentrations of $\mathrm{Rn}-222$ and $\mathrm{Rn}-220$ gas near the site are both typically $0.2 \mathrm{pCi} /\left(7 \mathrm{~Bq} / \mathrm{m}^{3}\right)$. On-site work zone measurements of both $\mathrm{Rn}-222$ and $\mathrm{Rn}-220$ gas and progeny indicate elevated concentrations, particularly in localized areas where remedial actions involve the disturbance of raffinate sludge or other radium-laden wastes. The maximum hourly Rn-222 and Rn-220 concentrations recorded on site in 1997 were approximately $49 \mathrm{pCi} / 1$ $\left(1.8 \mathrm{E} 3 \mathrm{~Bq} / \mathrm{m}^{3}\right)$ and $527 \mathrm{pCi} / 1\left(1.9 \mathrm{E} 4 \mathrm{~Bq} / \mathrm{m}^{3}\right)$, respectively. The maximum $\mathrm{Rn}-222$ concentration was measured in October alongside Raffinate Pit 2, while the maximum Rn-220 concentration was measured in May in the northeast portion of Raffinate Pit 4. Monthly average continuous radon and thoron concentrations at Raffinate Pit 4 tend to be on the order of two to 10 times lower than the maximum values reported here. These values are higher than comparable measurements taken using track etch and electret detectors because the continuous monitors are placed in the immediate vicinity of work zones, while track etch and electret detectors are placed along the raffinate pit berms and site perimeter fence. Data collected with continuous radon and working level monitors are sporadic throughout the year because they are collected only during activities that have the potential to emit radon into the air.

\subsubsection{Data Analysis}

Statistical analysis of the F-type track etch integrated radon results indicated that, at the $95 \%$ confidence level, measured concentrations at 12 of the 14 raffinate pit locations were greater than the combined background station result. The results for other stations were not statistically distinguishable from background levels. 
Table 4-3 1997 Electret Radon-222 Results ${ }^{(\mathrm{a})}$

\begin{tabular}{|c|c|c|c|c|c|c|}
\hline LOCATION ID & $\begin{array}{c}\text { 1ST } \\
\text { QUARTER } \\
{\text { (pCi } /)^{(b)}}^{(b}\end{array}$ & $\begin{array}{c}\text { 2ND } \\
\text { QUARTER } \\
\text { (pCi/l) }^{(b)}\end{array}$ & $\begin{array}{c}\text { 3RD } \\
\text { QUARTER } \\
\text { (pCi/l) }^{(b)}\end{array}$ & $\begin{array}{c}\text { 4TH } \\
\text { QUARTER } \\
\text { (pCi/I) }^{(\mathrm{p})}\end{array}$ & $\begin{array}{l}\text { ANNUAL } \\
\text { AVERAGE } \\
(p C i / l)^{(b)}\end{array}$ & $\begin{array}{l}\text { ANNUAL } \\
\text { STANDARD } \\
\text { DEVIATION }\end{array}$ \\
\hline ET-1002 & 0.4 & 0.2 & 0.4 & 0.3 & 0.3 & 0.08 \\
\hline ET-1009 & 0.5 & - & - & - & 0.5 & N/A \\
\hline ET-1010 & 0.4 & - & - & - & 0.4 & N/A \\
\hline ET-2004 & 0.3 & 0.3 & 0.5 & 0.5 & 0.4 & 0.12 \\
\hline ET-2006 & 0.3 & 0.3 & 0.6 & 0.3 & 0.3 & 0.14 \\
\hline ET-2008 & 0.2 & 0.3 & 0.5 & 0.2 & 0.3 & 0.11 \\
\hline ET-3000 & 0.5 & 0.3 & 0.4 & 0.3 & 0.4 & 0.09 \\
\hline ET-3001 & 0.4 & 0.3 & 0.5 & 0.3 & 0.4 & 0.12 \\
\hline ET-3002 & 0.4 & 0.3 & 0.4 & 0.4 & 0.4 & 0.05 \\
\hline ET-3003 & 0.3 & 0.4 & 0.7 & 0.4 & 0.5 & 0.17 \\
\hline ET-3004 & 0.2 & 0.2 & 0.5 & 0.4 & 0.4 & 0.14 \\
\hline ET-3005 & 0.3 & 0.3 & 0.6 & 0.4 & 0.4 & 0.14 \\
\hline ET-3006 & 0.4 & 0.4 & 0.6 & 0.2 & 0.4 & 0.18 \\
\hline ET-3007 & 0.3 & 0.2 & 0.5 & 0.3 & 0.3 & 0.11 \\
\hline ET-3008 & 0.4 & 0.4 & 0.7 & 0.2 & 0.4 & 0.18 \\
\hline ET-3009 & 0.6 & 0.4 & 0.3 & 0.2 & 0.4 & 0.16 \\
\hline ET-3010 & 0.5 & 0.3 & 0.6 & 0.4 & 0.5 & 0.12 \\
\hline ET-3011 & 0.5 & 0.4 & 0.3 & 0.3 & 0.4 & 0.10 \\
\hline ET-3012 & 0.8 & 0.3 & 0.3 & 0.2 & 0.4 & 0.27 \\
\hline ET-3013 & 0.2 & 0.3 & 0.4 & 0.3 & 0.3 & 0.08 \\
\hline ET-3013TSA & 0.5 & - & - & - & 0.5 & N/A \\
\hline ET-3014 & 0.3 & 0.4 & 0.6 & 0.3 & 0.4 & 0.13 \\
\hline ET-3015 & 0.3 & 0.4 & 0.3 & 0.4 & 0.3 & 0.07 \\
\hline ET-3016 & 0.4 & 0.3 & 0.3 & 0.2 & 0.3 & 0.07 \\
\hline ET-3017 & 0.4 & 0.2 & 0.2 & 0.3 & 0.3 & 0.10 \\
\hline ET-3018 & 0.3 & 0.3 & 0.5 & 0.4 & 0.4 & 0.11 \\
\hline ET-4003 & 0.3 & 0.3 & 0.5 & 0.3 & 0.4 & 0.11 \\
\hline ET-4009* & 0.4 & 0.3 & 0.5 & 0.3 & 0.4 & 0.10 \\
\hline
\end{tabular}

(a) Results include natural background levels.

(b) To convert from $\mathrm{pCi} / \mathrm{l}$ to $\mathrm{Bq} / \mathrm{m}^{3}$, multiply by 37 .

- Background station.

- Measurement not collected.

N/A No standard deviation calculated. 
Table 4-4 1997 Electret Radon-220 Results ${ }^{(a)}$

\begin{tabular}{|c|c|c|c|c|c|c|}
\hline LOCATION ID & $\begin{array}{c}\text { 1ST } \\
\text { QUARTER } \\
\text { (pCi//) }^{(b)}\end{array}$ & $\begin{array}{c}\text { 2ND } \\
\text { QUARTER } \\
\text { (pCi/l) }^{(b)}\end{array}$ & $\begin{array}{c}\text { 3RD } \\
\text { QUARTER } \\
\text { (pCi/I) }^{(b)}\end{array}$ & $\begin{array}{c}\text { 4TH } \\
\text { QUARTER } \\
\text { (pCi/l) }^{(b)}\end{array}$ & $\begin{array}{l}\text { ANNUAL } \\
\text { AVERAGE } \\
\text { (pCi/l) }^{\text {(b) }}\end{array}$ & $\begin{array}{l}\text { ANNUAL } \\
\text { STANDARD } \\
\text { DEVIATION }\end{array}$ \\
\hline ET-1002 & 0.8 & 0.8 & 0.8 & 0.5 & 0.7 & 0.15 \\
\hline ET-1010 & 0.3 & - & - & - & 0.3 & N/A \\
\hline ET-3000 & - & 3.3 & 1.1 & 0.7 & 1.7 & 1.44 \\
\hline ET-3001 & - & 10.3 & 2.9 & 1.1 & 4.7 & 4.87 \\
\hline ET-3002 & - & 5.0 & 1.9 & 1.5 & 2.8 & 1.92 \\
\hline ET-3003 & - & - & - & 0.6 & 0.6 & N/A \\
\hline ET-3006 & 3.2 & 6.9 & 2.1 & 0.6 & 3.2 & 2.68 \\
\hline ET-3007 & - & - & 3.6 & 2.6 & 3.1 & 0.68 \\
\hline ET-3010 & 0.8 & 1.5 & 1.2 & 2.0 & 1.4 & 0.51 \\
\hline ET-3013 & 1.1 & 2.4 & 3.9 & 3.1 & 2.6 & 1.19 \\
\hline ET-3013TSA & 0.8 & - & - & - & 0.8 & N/A \\
\hline ET-3015 & 1.1 & 1.7 & 1.7 & 1.4 & 1.5 & 0.27 \\
\hline ET-3016 & 0.9 & 0.9 & 1.0 & 0.5 & 0.8 & 0.19 \\
\hline ET-4003 & 0.4 & 0.3 & 0.6 & 0.3 & 0.4 & 0.16 \\
\hline ET-4009* & 0.4 & 0.2 & 0.5 & 0.5 & 0.4 & 0.12 \\
\hline
\end{tabular}

(a) Results include natural background levels.

(b) To convert from $\mathrm{pCi} / \mathrm{l}$ to $\mathrm{Bq} / \mathrm{m}^{3}$, multiply by 37 .

- Background station.

N/A No standard deviation calculated.

- Discontinued or new monitoring location; no data for this quarter. 
Statistical analysis of the M-type track etch $\mathrm{Rn}-220$ results indicated that, at the $95 \%$ confidence level, the annual average concentration at the quarry perimeter station was greater than the background station result. The analysis also indicated that six of the eight raffinate pit locations exceeded background levels. Results for all other stations were statistically indistinguishable from background levels.

\subsubsection{Chemical Plant and Raffinate Pits}

Statistical analysis of 12 radon track etch monitoring locations indicated results greater than background levels. Three of the 12 stations, RD-3001, RD-3002, and RD-3003, are located along the western chemical plant perimeter near Raffinate Pit 4 . The remaining nine stations (RD-3007 through RD-3015) are located along the berms of Raffinate Pits 1, 2, 3, and 4 inside the site boundary. The annual average concentrations for these stations exceeded background levels by $0.2 \mathrm{pCi} / 1\left(7.4 \mathrm{~Bq} / \mathrm{m}^{3}\right)$ to $6.0 \mathrm{pCi} / 1\left(220 \mathrm{~Bq} / \mathrm{m}^{3}\right)$. These results were anticipated, given the sludge consolidation and excavation activities in the raffinate pits area. The quarterly measured radon concentrations for all stations ranged from $0.1 \mathrm{pCi} / 1\left(3.7 \mathrm{~Bq} / \mathrm{m}^{3}\right)$ to $14.7 \mathrm{pCi} / 1\left(540 \mathrm{~Bq} / \mathrm{m}^{3}\right)$.

Statistical analysis of six $\mathrm{Rn}-220$ track etch monitoring locations indicated annual average results greater than background levels. Three of the six stations, RD-3001, 3002, and 3003, are located along the western chemical plant perimeter near Raffinate Pit 4 . The annual average concentration for these stations exceeded the annual average background by $0.7 \mathrm{pCi} / 1\left(26 \mathrm{~Bq} / \mathrm{m}^{3}\right)$ to $13.9 \mathrm{pCi} / 1\left(510 \mathrm{~Bq} / \mathrm{m}^{3}\right)$. The quarterly $\mathrm{Rn}-220$ measurements for all stations ranged from $0.1 \mathrm{pCi} / 1\left(3.7 \mathrm{~Bq} / \mathrm{m}^{3}\right)$ to $14.0 \mathrm{pCi} /\left(520 \mathrm{~Bq} / \mathrm{m}^{3}\right)$.

\subsubsection{Quarry}

Statistical analysis of track etch integrated radon monitoring results from the two quarry stations indicated that there was no reason to suspect, at the $95 \%$ confidence level, that these results exceeded background levels. However, Station RD-1002 was found to exceed the annual background concentration for $\mathrm{Rn}-220$, based on a statistical analysis of the annual M-type results. The annual average concentration for this station exceeded the annual background concentration by $0.1 \mathrm{pCi} / 1\left(3.7 \mathrm{~Bq} / \mathrm{m}^{3}\right)$. The quarterly measured results for integrated radon from both quarry stations ranged from $0.1 \mathrm{pCi} / 1\left(3.7 \mathrm{~Bq} / \mathrm{m}^{3}\right)$ to $0.5 \mathrm{pCi} / 1\left(19 \mathrm{~Bq} / \mathrm{m}^{3}\right)$. Quarterly $\mathrm{Rn}-220$ results at the quarry station ranged from $0.1 \mathrm{pCi} / /\left(3.7 \mathrm{~Bq} / \mathrm{m}^{3}\right)$ to $0.3 \mathrm{pCi} / 1\left(11 \mathrm{~Bq} / \mathrm{m}^{3}\right)$. Although no remedial actions occurred at the quarry during 1997, the slightly elevated $\mathrm{Rn}-220$ result indicates that residual thorium contamination may be present at the quarry upper rim area.

DOE/OR/21548-730, Rev. 0 


\subsubsection{Off-Site Locations}

Statistical analysis of both track etch integrated radon and $\mathrm{Rn}-220$ monitoring results from off-site locations (shown in Figure 4-3) indicated that there was no reason to suspect, at the $95 \%$ confidence level, that measured concentrations at any of the stations were greater than background levels. The quarterly integrated radon concentration measurements at off-site locations ranged from $0.1 \mathrm{pCi} / 1\left(3.7 \mathrm{~Bq} / \mathrm{m}^{3}\right)$ to $0.5 \mathrm{pCi} / 1\left(19 \mathrm{~Bq} / \mathrm{m}^{3}\right)$. Quarterly results for $\mathrm{Rn}-220$ at the off-site stations ranged from $0 \mathrm{pCi} / 1\left(0 \mathrm{~Bq} / \mathrm{m}^{3}\right)$ to $0.4 \mathrm{pCi} / 1\left(15 \mathrm{~Bq} / \mathrm{m}^{3}\right)$. These results are similar to results obtained during previous years.

\subsubsection{Five-Year Trend Analysis of Integrated Radon Gas}

Figure 4-6 shows 5 years of annual average track etch integrated radon concentrations for the monitoring stations at the quarry, chemical plant, raffinate pits, and off-site locations. These monitoring results include natural background radon concentrations. Radon gas levels at the quarry have maintained a downward trend since the peak of bulk waste removal in 1994 . Conversely, measurements at the raffinate pits have trended upward since 1993; however, no DCGs were exceeded in 1997, and estimates of emissions through the end of the project indicate no reason to believe that DCGs will be exceeded in the future (Ref. 75). These upward trends are attributable to ongoing remediation projects in the raffinate pits. Annual average concentrations at the chemical plant area and off site indicate no significant trend.

\subsection{Gamma Radiation Monitoring}

\subsubsection{Program Overview}

Gamma radiation is emitted from natural, cosmic, and manmade sources. The earth naturally contains gamma radiation-emitting substances, such as uranium, thorium, and potassium (K-40). Cosmic radiation originates in outer space and filters through the atmosphere to the earth. Together, these two sources comprise the majority of natural gamma background radiation. The United Nations Scientific Committee on the Effects of Atomic Radiation (UNSCEAR) (Ref. 33) estimates the typical gamma radiation dose is $35 \mathrm{mrem} / \mathrm{year}$ $(0.35 \mathrm{mSv} /$ year) from the earth and $30 \mathrm{mrem} /$ year $(0.30 \mathrm{mSv} /$ year $)$ from cosmic sources. The total estimated background radiation dose equivalent due to gamma exposure is thus $65 \mathrm{mrem} /$ year (0.65 mSv/year).

Gamma radiation was monitored in 1997 using TLDs at 15 monitoring stations: seven at the site perimeter, one at the quarry perimeter, and seven off site. The locations are denoted by a "TD" prefix on Figures 4-1 through 4-5. Stations TD-4005 and TD-4009 measure natural background at locations unaffected by the site. The TLDs are exchanged and read every calendar quarter. 


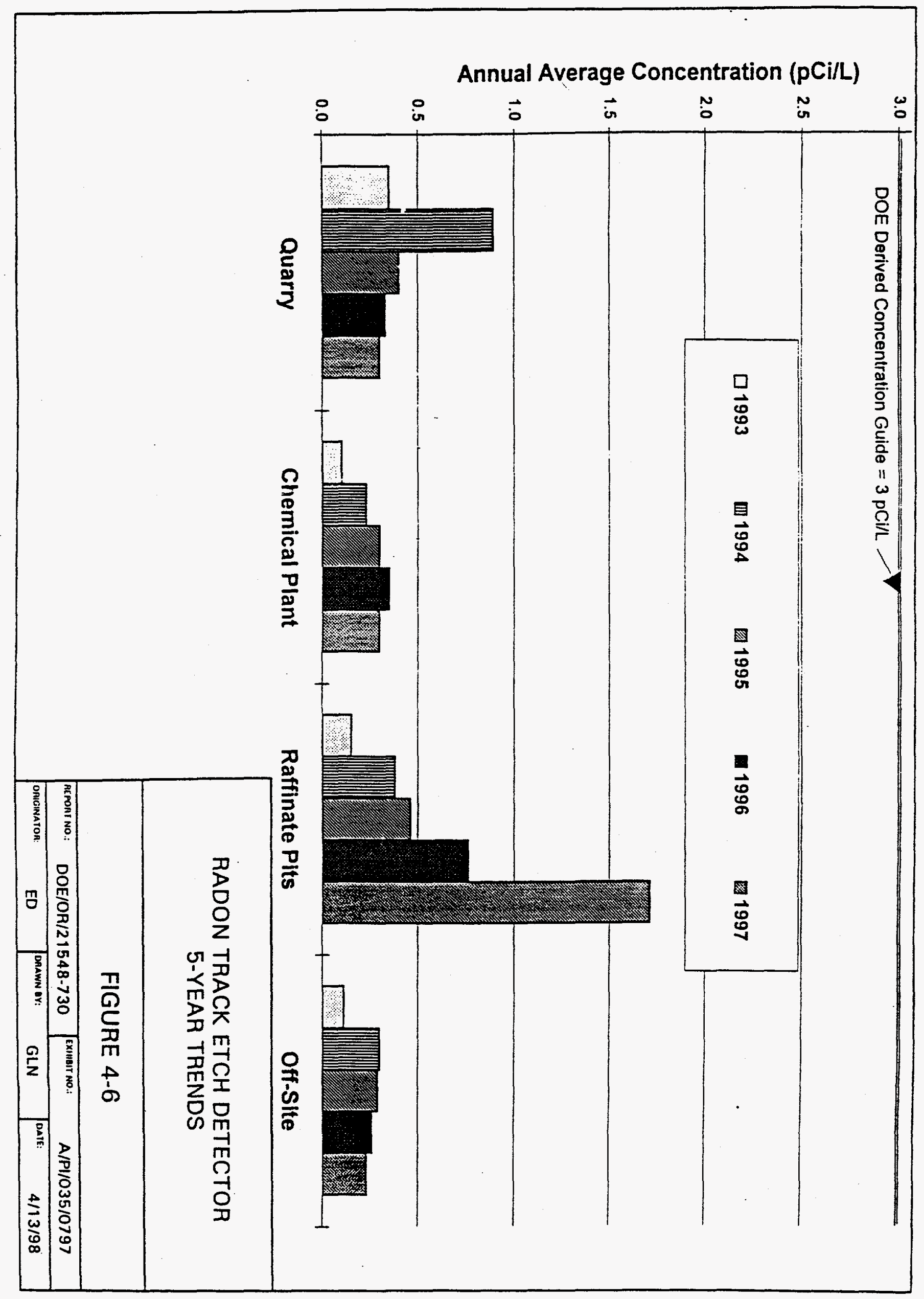




\subsubsection{Applicable Standards}

No specific standard for gamma radiation is stated in the DOE orders. However, DOE Order 5400.5 specifies that members of the public shall receive less than $100 \mathrm{mrem} / \mathrm{year}$ (1.0 mSv/year) from DOE operations for all exposure pathways, excluding exposure to natural background radiation.

\subsubsection{Monitoring Results}

Table 4-5 summarizes quarterly and annual total gamma radiation monitoring results. The table includes quarterly and annual totals, the annual sample standard deviation for each station, and whether a station's annual monitoring results are statistically distinguishable from background levels as determined by a one-tailed Student's t-test at the $95 \%$ confidence level. As shown in the table, one detector was damaged or missing during the year, resulting in missing quarterly data for that station.

Gamma background levels for 1997 were determined by averaging the annual total measurement from the two background stations. The annual average result from these stations was $59 \mathrm{mrem} /$ year $(0.59 \mathrm{mSv} /$ year $)$ with a standard deviation of $1 \mathrm{mrem} / \mathrm{year}(0.01 \mathrm{mSv} / \mathrm{year})$. This average background is comparable to the UNSCEAR 1982 estimate of $65 \mathrm{mrem} /$ year (0.65 mSv/year) (Ref. 33).

\subsubsection{Data Analysis}

Statistical analysis of TLD results revealed that, at the $95 \%$ confidence level, six stations had annual results greater than background levels. These stations included TD-2004 and TD-2025, located along the northeastern perimeter of the chemical plant; and TD-3001, TD-3002, TD-3003, and TD-3004, located around the raffinate pits and TSA. The analysis further revealed that results for all other stations were indistinguishable from background levels. 
Table 4-5 1997 Environmental TLD Results ${ }^{(a)}$

\begin{tabular}{|c|c|c|c|c|c|c|c|}
\hline LOCATION & $\begin{array}{c}\text { 1ST } \\
\text { QUARTER } \\
\text { (mrem) f) }\end{array}$ & $\begin{array}{c}\text { 2ND } \\
\text { QUARTER } \\
\text { (mrem () })^{(c)}\end{array}$ & $\begin{array}{c}\text { 3RD } \\
\text { QUARTER } \\
\text { (mrem) })^{(c)}\end{array}$ & $\begin{array}{c}\text { 4TH } \\
\text { QUARTER } \\
\text { (mrem f) }\end{array}$ & $\begin{array}{c}\text { ANNUAL } \\
\text { TOTAL } \\
\left.(\mathrm{mrem} / \mathrm{yr})^{\mathrm{c}}\right)\end{array}$ & $\begin{array}{l}\text { STANDARD } \\
\text { DEVIATION }\end{array}$ & $\begin{array}{c}\text { STATISTICALLY } \\
\text { SIGNIFICANT } \\
(\mathrm{X})^{(\mathrm{d})}\end{array}$ \\
\hline \multicolumn{8}{|c|}{ WELDON SPRING QUARRY } \\
\hline TD-1002 & 15.3 & $\overline{15.4}$ & 14.6 & 15.5 & 61 & 0.4 & \\
\hline \multicolumn{8}{|c|}{ WELDON SPRING CHEMICAL PLANT } \\
\hline TD-2004 & 17.4 & 17.6 & 16.3 & 18.3 & 70 & 1 & $\bar{x}$ \\
\hline TD-2006 & 16.4 & 17.7 & 14.1 & 15.8 & 64 & 1 & \\
\hline TD-2025 & 16.7 & 18.8 & 15.6 & 17.7 & 69 & 1 & $\bar{x}$ \\
\hline \multicolumn{8}{|c|}{ WELDON SPRING RAFFINATE PITS } \\
\hline TD-3001 & 30.0 & 31.8 & 16.9 & 17.6 & 96 & 8 & $\bar{x}$ \\
\hline TD-3002 & 39.9 & 39.2 & 20.0 & 19.5 & 119 & 11 & $\bar{x}$ \\
\hline TD-3003 & 21.3 & 24.3 & 21.2 & 20.0 & 87 & 2 & $\bar{x}$ \\
\hline TD-3004 & 16.9 & 16.9 & 15.7 & 19.6 & 69 & 2 & $\bar{x}$ \\
\hline \multicolumn{8}{|c|}{ OFF SITE } \\
\hline$T D-4001^{(0)}$ & 17.1 & \#\# & 14.8 & 16.4 & 64 & 1 & \\
\hline TD-4002 & 14.3 & 14.0 & 12.2 & 14.0 & 55 & 1 & \\
\hline TD-4003 & 12.9 & 14.7 & 11.3 & 13.3 & 52 & 1 & \\
\hline TD-4005 & 15.9 & 16.6 & 13.3 & 14.3 & 60 & 2 & \\
\hline TD-4007 & 15.7 & 15.4 & 14.3 & 15.2 & 61 & 1 & \\
\hline RTD-4009 & 15.1 & 15.1 & 13.4 & 14.8 & 58 & 1 & \\
\hline$T D-4013^{(5)}$ & $\overline{-}$ & - & - & 16.4 & 66 & N/A & \\
\hline
\end{tabular}

* Denotes background location.

(a) Results include natural background gamma radiation.

(b) To calculate the annual total, missing data were replaced with the average of the recorded quarterly results for a given station.

(c) To convert from mrem to $\mathrm{mSv}$, divide by 100 .

(d) Statistical significance is determined by comparing the total annual concentration for a monitoring location with the total annual background concentration, using a one-tailed Student's t-test at the $95 \%$ confidence level.

- No measurement taken.

** Denotes lost or damaged TLD.

\subsubsection{Chemical Plant/Raffinate Pits}

Annual total TLD gamma radiation measurements at the chemical plant and raffinate pits ranged from $64 \mathrm{mrem}(0.64 \mathrm{mSv})$ to $119 \mathrm{mrem}(1.19 \mathrm{mSv})$. These results are generally higher than previous years for these areas due to quarry bulk waste storage at the TSA and remediation activities in the raffinate pits, including the sludge consolidation work in Raffinate Pit 4 and excavation of sludge from Raffinate Pits 1 and 2.

\subsubsection{Quarry}

The annual total gamma radiation measurement from TLDs at the quarry was 61 mrem $(0.61 \mathrm{mSv})$. This result is comparable to previous years for this area. 


\subsubsection{Off-Site Locations}

The annual total gamma radiation measurements from TLDs at off-site locations ranged from $52 \mathrm{mrem}(0.52 \mathrm{mSv})$ to $66 \mathrm{mrem}(0.66 \mathrm{mSv})$. These results are comparable to previous years for these areas.

\subsubsection{Five-Year Trend Analysis of TLDs}

Gamma radiation exposure monitoring results for the last 5 years are shown graphically in Figure 4-7. The graph shows yearly monitoring result totals for the chemical plant, raffinate pits, quarry, and off-site locations. The results include the natural background dose rate. Results indicate a continued upward trend in measurements around the raffinate pits due to ongoing remediation work in the area. However, no regulatory exposure limits were approached as a result of this increase.

\subsection{Radioactive Air Particulate Monitoring}

\subsubsection{Program Overview}

Radioactive air particulates are airborne dust particles that contain radioactive contaminants. Background concentrations of radioactive air particulates are affected by the soil concentrations of naturally occurring radionuclides, soil moisture content, meteorological conditions, and geological conditions. Many areas on site contain above background concentrations of soil contamination, which can result in increased airborne radioactive particulate concentrations. Increased airborne radioactive particulate emissions from the site can result from wind erosion of contaminated soils piles or remedial work activities, such as moving equipment and vehicles in contaminated areas.

In 1997, the WSSRAP monitored radioactive air particulates weekly at 15 continuous permanent low volume air sampling stations: seven at the chemical plant perimeter, two at the quarry, and six in off-site locations. These locations are denoted by an "AP" prefix on Figures 4-1, 4-2, 4-3, and 4-4. Additional low-volume air monitoring samplers may be deployed on a temporary basis when current activities warrant their use. The low volume samplers collect airborne particulates by drawing ambient air at a flow rate of approximately $40 \mathrm{l} /$ minute through mixed cellulose ester filters with a 0.80 micron pore size. The filters are then analyzed using a gas flow proportional counter to determine the amount of long-lived gross alpha activity in the particulates present on the filter surface. 


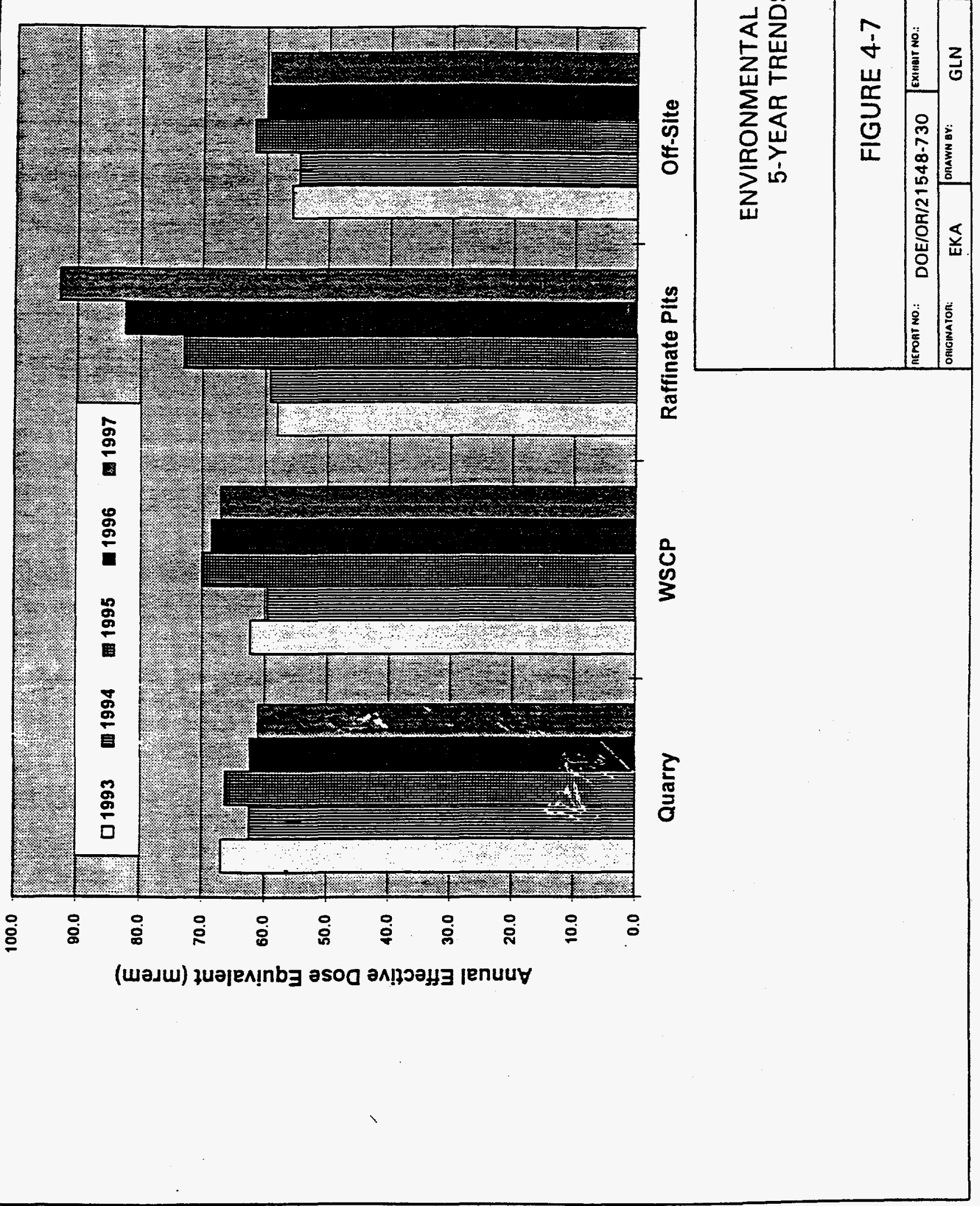




\subsubsection{Applicable Standards}

The Weldon Spring site is contaminated with a combination of alpha-emitting radionuclides, including isotopes of uranium, thorium, and their decay products. The gross alpha concentrations measured by the low-volume samplers thus include contributions from a wide array of alpha emitters. The DCGs for inhalation of the radionuclides found at the WSSRAP are listed in Chapter III of DOE Order 5400.5.

\subsubsection{Monitoring Results}

The annual average long-lived gross alpha concentrations and standard deviations for the 15 permanent low volume stations are summarized in Table 4-6. Annual averages were calculated using uncensored weekly air particulate analytical results. Uncensored data refers to all results, including those near or below the minimum detectable concentration (MDC). The DOE Environmental Regulatory Guide for Radiological Effluent Monitoring and Environmental Surveillance (Ref. 1) requires the use of uncensored data to minimize any bias in arithmetic averages and standard deviation calculations. Annual results represent the average of up to 52 weeks of data for each monitoring station other than the background station (AP-4012). The reported background result is a 104-week (2-year) average, which provides a more accurate longterm result than if any 52 weeks of background data were used.

Table 4-6 1997 Radioactive Air Particulate Gross Alpha Results

\begin{tabular}{|c|c|c|c|c|}
\hline $\begin{array}{l}\text { MONITORING } \\
\text { STATION } \\
\text { IDENTIFICATION } \\
\text { NUMBER }\end{array}$ & $\begin{array}{l}\text { ANNUAL AVERAGE } \\
\text { LONG-LIVED GROSS } \\
\text { ALPHA } \\
\text { CONCENTRATION } \\
(\mathrm{X} 1 E-15 \mu \mathrm{CI} / \mathrm{ml})^{(\mathrm{b})(\mathrm{d})}\end{array}$ & $\begin{array}{c}\text { STANDARD } \\
\text { DEVIATION } \\
(\times 1 E-15 \mu \mathrm{Ci} / \mathrm{ml})\end{array}$ & $\begin{array}{c}\text { NUMBER OF } \\
\text { SAMPLES TOTAL } \\
\text { NUMBER OF WEEKS }\end{array}$ & $\begin{array}{l}\text { STATISTICALLY } \\
\text { SIGNIFICANT }(X)^{(C)}\end{array}$ \\
\hline AP-2001 & 1.29 & 0.381 & $52 / 52$ & \\
\hline AP-2002 & 1.47 & 0.528 & $52 / 52$ & $x$ \\
\hline AP-3003 & 1.90 & 2.10 & $52 / 52$ & $x$ \\
\hline AP-3004 & 1.67 & 0.829 & $52 / 52$ & $x$ \\
\hline AP-2005 & 1.53 & 0.599 & $51 / 52$ & $x$ \\
\hline AP-4006 & 1.40 & 0.431 & $51 / 52$ & \\
\hline AP-4007 & 1.24 & 0.473 & $52 / 52$ & \\
\hline AP-4008 & 1.31 & 0.401 & $50 / 52$ & \\
\hline AP-1009 & 1.30 & 0.427 & $51 / 52$ & \\
\hline AP-4011 & 1.31 & 0.452 & $52 / 52$ & \\
\hline AP $-4012^{(a)}$ & 1.28 & 0.540 & $104 / 104$ & \\
\hline AP-4013 & 1.21 & 0.584 & $22 / 52$ & \\
\hline AP-3014 & 1.40 & 0.561 & $52 / 52$ & \\
\hline AP-1017 & 1.16 & 0.416 & $51 / 52$ & \\
\hline AP-2025 & 1.25 & 0.388 & $51 / 52$ & \\
\hline
\end{tabular}
(a) Indicates background monitoring station. Background concentration is a 2-year average.
(b) The annual average gross alpha concentrations include background and were calculated using uncensored data, which includes results less than reported minimum detectable concentrations
(c) Statistical significance is determined by comparing the annual average concentration for a monitoring 
location with the 2-year (104-week) background average concentration, using a one-tailed Student's ttest at the $95 \%$ confidence level.

(d) To convert from $\mu \mathrm{Ci} / \mathrm{ml}$ to $\mathrm{Bq} / \mathrm{ml}$, multiply by 37,000 .

The typical MDC for low volume air particulate sampling at the WSSRAP is $3.3 \mathrm{E}-16 \mu \mathrm{Ci} / \mathrm{ml}(1.2 \mathrm{E}-11 \mathrm{~Bq} / \mathrm{ml})$. This $\mathrm{MDC}$ is low enough to allow detection of Th-232, which has the lowest $\mathrm{DCG}$ at the site of $7.0 \mathrm{E}-15 \mu \mathrm{Ci} / \mathrm{ml}(2.6 \mathrm{E}-10 \mathrm{~Bq} / \mathrm{ml})(\mathrm{DOE} 5400.5)$. If an individual inhales airborne contaminants at the DCG for 1 year, the resulting committed effective dose equivalent is $100 \mathrm{mrem}(1 \mathrm{mSv})$.

\subsubsection{Data Analysis}

Statistical analysis of the annual results from the low volume airborne particulate samplers indicated that four monitoring stations had results that were greater than background levels. Station AP-4012 indicated a 104-week background average concentration of $1.28 \mathrm{E}-15 \mu \mathrm{Ci} / \mathrm{ml}$ (4.74E-11 Bq/ml).

\subsubsection{Chemical Plant/Raffinate Pits}

The average concentrations at the chemical plant/raffinate pits perimeter ranged from $1.25 \mathrm{E}-15 \mu \mathrm{Ci} / \mathrm{ml}(4.63 \mathrm{E}-11 \mathrm{~Bq} / \mathrm{ml})$ to $1.90 \mathrm{E}-15 \mu \mathrm{Ci} / \mathrm{ml}(7.03 \mathrm{E}-11 \mathrm{~Bq} / \mathrm{ml})$. Four monitoring stations, AP-2002, AP-3003, AP-3004, and AP-2005 were statistically greater than background. Overall, the chemical plant and raffinate pits results are slightly higher than those measured in 1996.

\subsubsection{Quarry}

The average concentrations at the quarry perimeter ranged from $1.16 \mathrm{E}-15 \mu \mathrm{Ci} / \mathrm{ml}$ $(4.29 \mathrm{E}-11 \mathrm{~Bq} / \mathrm{ml})$ to $1.30 \mathrm{E}-15 \mu \mathrm{Ci} / \mathrm{ml}(4.81 \mathrm{E}-11 \mathrm{~Bq} / \mathrm{ml})$. These results are lower than those measured during 1996 and previous years.

\subsubsection{Off-Site Locations}

The average concentrations at off-site locations ranged from $1.21 \mathrm{E}-15 \mu \mathrm{Ci} / \mathrm{ml}$ $(4.48 \mathrm{E}-11 \mathrm{~Bq} / \mathrm{ml})$ to $1.40 \mathrm{E}-15 \mu \mathrm{Ci} / \mathrm{ml}(5.18 \mathrm{E}-11 \mathrm{~Bq} / \mathrm{ml})$. These results are similar to those measured during previous years. 


\subsection{Airborne Asbestos Monitoring}

Because no asbestos abatement work occurred at the Weldon Spring site during 1997, no environmental asbestos monitoring was conducted. Environmental asbestos monitoring will take place in 1998 as work activities warrant. 


\section{RADIATION DOSE ANALYSIS}

This section evaluates the effects of atmospheric releases and surface and groundwater discharges of radiological contaminants from the Weldon Spring Site Remedial Action Project (WSSRAP). Potential annual dose equivalents to the general public have been calculated and are presented here. These calculations are compared against U.S. Department of Energy (DOE) guidelines contained in DOE Order 5400.5.

Dose calculations are presented in this section for a maximally exposed individual and a collective population. The exposure conditions used in the dose calculations are further discussed in respective environmental monitoring sections of this report.

Dose calculations related to airborne emissions as required by 40 CFR 61 , Subpart $\mathrm{H}$ (National Emission Standards for Emissions of Radionuclides Other Than Radon From Department of Energy Facilities) are presented in Section 6, National Emission Standards for Hazardous Air Pollutants (NESHAPS) Program.

\subsection{Highlights}

- The largest total effective dose equivalent (TEDE) to a maximally exposed individual from all pathways combined was $2.5 \mathrm{mrem}(0.025 \mathrm{mSv})$, estimated for an individual who works full-time at the Missouri Highway and Transportation Department Maintenance (MHTD) facility. This value represents $2.5 \%$ of the DOE guideline of 100 mrem ( $1 \mathrm{mSv}$ ) above background levels.

- The collective population dose equivalent was estimated to be 0.13 person-rem (1.3E-3 person-Sv) for users of the Busch Memorial Conservation Area and employees of the MHTD and WSSRAP Administration Building.

\subsection{Pathway Analysis}

In developing specific elements of the WSSRAP environmental monitoring program, potential exposure pathways and health effects of the radioactive and chemical materials present on site are reviewed annually to determine which pathways are complete. This pathway analysis is detailed in the site Environmental Monitoring Plan (Ref. 42). As required by DOE Order 5400.1 , evaluation of each exposure pathway is based on the sources, release mechanisms, types, and probable environmental fates of contaminants, and the locations and activities of potential receptors. Pathways are then reviewed to determine whether a link exists between one or more contaminant sources, or between one or more environmental transport processes, to an exposure point where human or ecological receptors are present. If it is determined that a link exists, the pathway is termed complete. Complete pathways are used to assess radiological and 
nonradiological exposures. Each complete pathway is reviewed to determine whether a potential for exposure was present during the time frame of concern. If this is the case, the pathway is termed applicable. Only applicable pathways are considered in estimates of dose.

Table 5-1 lists the six complete pathways for exposure from radiological contaminants evaluated by the WSSRAP environmental monitoring program. These pathways are used to evaluate monitoring requirements and to determine radiological exposures from the site. Of the six complete pathways, five were applicable in 1997 and were thus incorporated into radiological dose estimates. These are Liquid (B), Liquid (C), Airborne (A), Airborne (B), and External. Assessments of potential exposure routes in the Feasibility Study for Remedial Action at the Chemical Plant Area of the Weldon Spring Site (Ref. 69) have shown that the dose potential for pathways not listed in Table $5-1$ is negligibly small.

Table 5-1 Complete Radiological Exposure Pathways for the Weldon Spring Site

\begin{tabular}{|l|l|c|}
\hline $\begin{array}{c}\text { EXPOSURE } \\
\text { PATHWAY }\end{array}$ & \multicolumn{1}{|c|}{ PATHWAY DESCRIPTION } & $\begin{array}{c}\text { APPLICABLE TO } \\
\text { 1997 DOSE } \\
\text { ESTIMATE }\end{array}$ \\
\hline Liquid(A) & Ingestion of groundwater from local wells downgradient from the site. & N \\
\hline Liquid(B) & Ingestion of game and fish inhabiting wildlife area. & $Y$ \\
\hline Liquid(C) & Ingestion of surface water and sediments. & $Y$ \\
\hline Airborne(A) & $\begin{array}{l}\text { Inhalation of particulates dispersed through wind erosion and remedial } \\
\text { action. }\end{array}$ & Y \\
\hline Airborne(B) & $\begin{array}{l}\text { Inhalation of radon and radon decay products emitted from } \\
\text { contaminated soils/wastes. }\end{array}$ & $Y$ \\
\hline External & Direct gamma radiation from contaminated soils/wastes. & $Y$ \\
\hline
\end{tabular}

As shown in Table 5-1, the Liquid (A) pathway is not applicable to the 1997 dose estimate for the WSSRAP. Concentrations of radioactive contaminants in the production wells near the Weldon Spring Quarry are currently comparable to background concentrations (see Section 8.5). In addition, no drinking water wells are located in the vicinity of the chemical plant and raffinate pits area.

The applicable radiological public dose guidelines for the WSSRAP are as follows:

- NESHAPs standard of $10 \mathrm{mrem}(0.10 \mathrm{mSv})$ effective dose equivalent annually due to airborne emissions other than radon at off-site receptor locations.

- DOE guideline of $100 \mathrm{mrem}(1 \mathrm{mSv})$ total effective dose equivalent for all exposure pathways on an annual basis (excluding background). 


\subsection{Radiological Release Estimates}

\subsubsection{Airborne Radiological Releases}

Estimates of radiological releases to air and surface water were calculated for radioactive particulates and thoron gas. No release estimate was made for $R n-222$ gas because $R n-222$ monitoring results at all perimeter stations were indistinguishable from background levels. Table 5-2 shows the estimated activity release of radionuclides to the environment, the corresponding mass released, and the half-life for each radionuclide.

As shown in Table 5-2, the estimated total off-site airborne $\mathrm{Rn}-220$ release was approximately $42 \mathrm{Ci}(1.55 \mathrm{E} 12 \mathrm{~Bq})$. Raffinate $\mathrm{Pit} 4$ is the primary source of $\mathrm{Rn}-220$ emissions at the Weldon Spring site. A series of box models was used to estimate the $R n-220$ release from the chemical plant. A box model was also used to estimate the $\mathrm{Rn}-220$ release from the quarry. The release estimates were based on the annual results of three F-type and three M-type radon monitoring stations at the chemical plant perimeter and one F-type and one M-type radon monitoring station at the quarry upper rim that were all found to exceed the annual average background concentration for $\mathrm{Rn}-220$ in 1997. Calculations and assumptions are provided in Appendix B.

Airborne particulate release estimates were calculated based on site characterization data and low volume monitoring results at four receptors located at the chemical plant perimeter. A series of box models was used to predict the airborne particulate release rate from the chemical plant. The assumptions used in estimating airborne releases are shown in Appendix B.

\subsubsection{Waterborne Radiological Releases}

During 1997, intermittent surface water runoff transported isotopes of uranium, thorium, and radium from the site through six major discharge routes. These include two water treatment plant outfalls and four storm water outfalls (see Section 7). These outfalls were monitored monthly as required under the site National Pollutant Discharge Elimination System (NPDES). Natural uranium concentrations measured in runoff water were multiplied by the natural uranium activity ratios for U-234, U-235, and U-238 (49.1\%, 2.3\%, and 48.6\%, respectively) to determine the waterborne releases of those isotopes. (All release estimates are based on data in Tables 7-3 and 7-5). All results are listed in Table 5-2.

\subsection{Exposure Scenarios}

Dose calculations were performed for maximally exposed individuals, collective population, and critical receptor locations for applicable exposure pathways (see Table 5-1) to assess dose due to radiological releases from the Weldon Spring site. First, conditions were set to 
Table 5-2 Radionuclide Emissions to the Environment

\begin{tabular}{|l|c|c|c|c|}
\hline & $\begin{array}{c}\text { ACTIVITY OF } \\
\text { RADIONUCLIDES } \\
\text { RADIONUCLIDE }\end{array}$ & $\begin{array}{c}\text { ACTIVITY OF } \\
\text { RADIONUCLIDES } \\
\text { RELEASED TO WATER } \\
\text { (Ci) }\end{array}$ & $\begin{array}{c}\text { MASS OF } \\
\text { RADIONUCLIDE } \\
\text { RELEASED (grams) }\end{array}$ & $\begin{array}{c}\text { HALF-LIFE } \\
\text { (Yrs) }\end{array}$ \\
\hline$U-238$ & $1.59 E-5$ & $7.32 E-3$ & $2.2 E 4$ & $4.47 E 09$ \\
\hline$U-235$ & $7.59 E-7$ & $3.46 E-4$ & 160 & $7.04 E 08$ \\
\hline$U-234$ & $1.59 E-5$ & $7.39 E-3$ & 1 & $2.46 E 05$ \\
\hline Ra-226 & $1.69 E-7$ & $6.39 E-4$ & $6.5 E-4$ & 1,600 \\
\hline Ra-228 & $1.30 E-7$ & $9.11 E-4$ & $3.4 E-6$ & 5.76 \\
\hline Th-230 & $7.84 E-6$ & $3.67 E-4$ & $1.82 E-2$ & $7.54 E 04$ \\
\hline Th-228 & $1.22 E-6$ & $3.61 E-4$ & $4.4 E-7$ & 1.91 \\
\hline Th-232 & $1.22 E-6$ & $3.19 E-4$ & $2.9 E 3$ & $1.40 E 10$ \\
\hline$R n-222$ & - & N/A & N/A & 3.82 days \\
\hline Rn-220 & 42 & N/A & N/A & 55.6 seconds \\
\hline Total Activity & 42 & $1.8 E-2$ & $2.5 E 4$ & N/A \\
\hline
\end{tabular}

N/A Not analyzed for this radionuclide.

- Not distinguishable from background at perimeter monitoring locations. Multiply by $3.7 \mathrm{E} 10$ to convert Ci to $\mathrm{Bq}$.

determine the total effective dose equivalent to a maximally exposed individual at each of the main site areas: the chemical plant and raffinate pits area, the quarry, and vicinity properties. A second dose equivalent for a collective population was calculated. A third set of dose equivalent calculations was performed to meet NESHAPs requirements (see Section 6).

Calculations using perimeter and off-site monitoring data determined the collective population dose equivalent to be less than 1 person-rem per year ( 0.01 person-Sv) from all pathways combined. Since all air monitoring stations (other than the background station) are within a $13 \mathrm{~km}(8.1 \mathrm{mi})$ radius of the site, and all results measured within this radius are well below NESHAPs and DOE limits, incorporating a dose calculation for a population within $80 \mathrm{~km}$ (49.6 mi) of the site is unnecessary. Rather, the collective population dose equivalent was calculated for specific target populations where complete exposure pathways were found to exist.

The scenarios and models used to evaluate these radiological exposures are conservative but appropriate. Although radiation doses can be calculated or measured for individuals, it is not appropriate to predict the health risk to a single individual using the methods prescribed here. Estimates of health risks are based on statistical models using epidemiological data collected from large groups of people exposed to radiation under various circumstances; therefore, they are not applicable to single individuals. Dose equivalents to a single individual are estimated by hypothesizing a maximally exposed individual and placing this individual in a reasonable but conservative scenario. This method is acceptable when the magnitude of the dose to a hypothetical maximally exposed individual is small, as is the case for the WSSRAP. The scenarios 
and resulting estimated doses used in the calculations are outlined in Table 5-3. In addition, the percentage of the DOE limit of $100 \mathrm{mrem}(1.0 \mathrm{mSv})$ TEDE is provided.

The collective population dose equivalent estimate, provided in units of person-rem (person-Sv), is the product of the effective dose equivalent estimate at an exposure point and the number of persons exposed. For the WSSRAP, exposure points are locations where members of the public are potentially exposed to above-background levels of airborne radioactive particulates, radon gas, external gamma radiation, or above-background radionuclide concentrations in water or food. The committed effective dose equivalent is calculated by estimating radionuclide concentrations in the air, water, and food at a given exposure point and applying standard breathing rates, ingestion rates, and dose equivalent conversion factors. These concentrations and reasonable exposure scenarios are used to estimate the amount of radioactivity ingested or inhaled by the potentially exposed population. The contribution from exposure to gamma radiation is then factored into the collective population dose equivalent.

All ingestion calculations were performed using the methodology described in International Commission on Radiation Protection (ICRP) Reports 26 and 30 (Ref. 26 and 27) for a 50-year committed effective dose equivalent (CEDE). Fifty-year CEDE conversion factors were obtained from the EPA Federal Guidance Report No. 11 (Ref. 28).

\subsection{Dose Equivalent Estimates}

Dose equivalent estimates for the exposure scenarios were calculated using 1997 monitoring data. Calculations for dose scenarios are provided in Appendix B. Dose equivalent estimates are well below the standards set by the DOE for annual public exposure and U.S. Environmental Protection Agency (EPA) NESHAPs limits.

The 1997 TEDEs for hypothetical maximally exposed individuals near the chemical plant and raffinate pits, quarry, and vicinity properties are $2.5 \mathrm{mrem}(0.025 \mathrm{mSv}), 0.001 \mathrm{mrem}$ $(0.01 \mu \mathrm{Sv})$, and $0.46 \mathrm{mrem}(4.6 \mu \mathrm{Sv})$, respectively. These values represent less than $3 \%$ of the DOE standard of $100 \mathrm{mrem}(1 \mathrm{mSv})$ above background for all exposure pathways. In comparison, the annual average exposure to natural background radiation in the United States results in a TEDE of approximately 300 mrem $(3 \mathrm{mSv})$ (Ref. 71). The collective population dose equivalent is 0.13 person-rem ( 0.0013 person-Sv) for recreational users of the Busch Memorial Conservation Area and employees of the Missouri Highway and Transportation Department facility and WSSRAP Administration Building. Assumptions are detailed in the following sections. 
Table 5-3 Exposure Scenarios for Weldon Spring Site Radiological Dose Estimates

\begin{tabular}{|c|c|c|c|c|c|c|c|c|}
\hline $\begin{array}{l}\text { EXPOSURE } \\
\text { SCENARIO }\end{array}$ & PATHWAY & ACTIVITY & MEDIA & $\begin{array}{l}\text { EXPOSURE } \\
\text { DURATION }\end{array}$ & $\begin{array}{l}\text { EXPOSUREI } \\
\text { INTAKE RATE }\end{array}$ & CONCENTRATION & $\begin{array}{c}\text { ESTIMATED } \\
\text { EFFECTIVE } \\
\text { DOSE } \\
\text { EQUIVALENT } \\
\text { (mrem) }\end{array}$ & $\begin{array}{l}\text { PERCENT } \\
\text { OF DOE } \\
\text { LIMIT }\end{array}$ \\
\hline \multirow{5}{*}{$\begin{array}{l}\text { WSCPNSRP } \\
\text { Hypothetical } \\
\text { Individual }\end{array}$} & Liquid(B) & N/A & N/A & N/A & N/A & N/A & N/A & N/A \\
\hline & Liquid(C) & N/A & N/A & N/A & N/A & N/A & N/A & N/A \\
\hline & External & $\begin{array}{c}\text { Working at MHTD } \\
\text { facility }\end{array}$ & $\begin{array}{c}\text { Direct } \\
\text { Exposure }\end{array}$ & 2,000 hours & $11 \mathrm{mrem} / \mathrm{yr}$ & NIA & 2.5 & $2.5 \%$ \\
\hline & Airborne(A) & N/A & N/A & N/A & N/A & N/A & N/A & N/A \\
\hline & Airborne(B) & N/A & N/A & N/A & N/A & N/A & N/A & N/A \\
\hline \multirow{5}{*}{$\begin{array}{c}\text { WSQ } \\
\text { Hypothetical } \\
\text { Individual }\end{array}$} & Liquid(B) & N/A & N/A & N/A & N/A & N/A & N/A & N/A \\
\hline & Liquid(C) & N/A & N/A & N/A & N/A & N/A & N/A & N/A \\
\hline & External & N/A & N/A & N/A & N/A & N/A & N/A & N/A \\
\hline & Airborne(A) & N/A & N/A & N/A & $\mathrm{N} / \mathrm{A}$ & N/A & N/A & N/A \\
\hline & Airborne(B) & $\begin{array}{c}\text { Walking near WSQ } \\
\text { perimeter }\end{array}$ & Air & 5 hours & $1.2 \mathrm{~m}^{3} /$ hour $^{(a)}$ & $\begin{array}{c}\mathrm{Rn}-2200.1 \mathrm{pCi} / \mathrm{l} ; 0.5 \% \\
\text { equilibrium }\end{array}$ & 0.001 & $0.001 \%$ \\
\hline \multirow{5}{*}{$\begin{array}{c}\text { WSVP } \\
\text { Hypothetical } \\
\text { Individual }\end{array}$} & Liquid(B) & N/A & $\bar{N} / \mathrm{A}$ & N/A & $\mathrm{N} / \mathrm{A}$ & N/A & N/A & N/A \\
\hline & Liquid(C) & $\begin{array}{c}\text { Drinking water from } \\
\text { Burgermeister } \\
\text { Spring }\end{array}$ & Water & N/A & $0.237 \mathrm{l} /$ week & $\begin{array}{c}\text { See Appendix B for list } \\
\text { of radionuclide } \\
\text { concentrations }\end{array}$ & 0.46 & $0.46 \%$ \\
\hline & External & N/A & $\mathrm{N} / \mathrm{A}$ & N/A & N/A & N/A & N/A & N/A \\
\hline & Airborne $(A)$ & N/A & N/A & N/A & N/A & N/A & N/A & N/A \\
\hline & Airborne(B) & N/A & $\mathrm{N} / \mathrm{A}$ & N/A & N/A & N/A & N/A & N/A \\
\hline
\end{tabular}




\begin{tabular}{|c|c|c|c|c|c|c|c|c|}
\hline $\begin{array}{l}\text { EXPOSURE } \\
\text { SCENARIO }\end{array}$ & PATHWAY & ACTIVITY & MEDIA & $\begin{array}{l}\text { EXPOSURE } \\
\text { DURATION } \\
\end{array}$ & $\begin{array}{l}\text { EXPOSURE/ } \\
\text { INTAKE RATE } \\
\end{array}$ & CONCENTRATION & $\begin{array}{c}\text { COLLECTIVE } \\
\text { POPULATION } \\
\text { DOSE } \\
\text { EQUIVALENT } \\
\text { (person-rem) }\end{array}$ & $\begin{array}{l}\text { PERCENT } \\
\text { OF DOE } \\
\text { LIMIT } \\
\end{array}$ \\
\hline \multirow[t]{6}{*}{$\begin{array}{l}\text { Collective } \\
\text { Population }\end{array}$} & Liquid(B) & $\begin{array}{l}\text { Fishing at Busch } \\
\text { Lake } 35 \\
\text { (population = } \\
80,000)\end{array}$ & Fish & $\bar{N} / A$ & $0.55 \mathrm{~g} / \mathrm{day}$ & $0.019 \mathrm{pCi} / \mathrm{g}$ & 0.082 & N/A \\
\hline & \multirow[t]{2}{*}{ Liquid(C) } & \multirow[t]{2}{*}{$\begin{array}{c}\text { Swimming at Busch } \\
\text { Lake } 35 \\
\text { (population }=5,985\end{array}$} & Sediments & $0.285 \mathrm{hr} /$ persor & $200 \mathrm{mg} / \mathrm{day}$ & $26.6 \mathrm{pCi} / \mathrm{g}$ & 0.0001 & $\overline{N / A}$ \\
\hline & & & Water & $0.285 \mathrm{hr} /$ persor & 0.05 liters/hour & $10.4 \mathrm{pCi} / /$ & 0.00024 & N/A \\
\hline & External & $\begin{array}{c}\text { Working at } \\
\text { MHTD Facility }\end{array}$ & $\begin{array}{c}\text { Direct } \\
\text { Exposure }\end{array}$ & 2,000 hours & $11 \mathrm{mrem} / \mathrm{yr}$ & N/A & 0.023 & N/A \\
\hline & Airborne(A) & $\begin{array}{l}\text { Working at } \\
\text { WSSRAP } \\
\text { Administration } \\
\text { Building } \\
\end{array}$ & Air & 2,500 & $1.2 \mathrm{~m}^{3} / \mathrm{hr}^{(\mathrm{a})}$ & $2.5 \mathrm{E}-16 \mu \mathrm{Ci} / \mathrm{ml}$ & 0.028 & N/A \\
\hline & Airborne(B) & N/A & N/A & N/A & N/A & N/A & N/A & N/A \\
\hline
\end{tabular}

N/A Indicates measurements for radioactivity for a media/exposure pathway at background levels.

WSCP Weldon Spring Chemical Plant

WSRP Weldon Spring raffinate pits.

WSQ Weldon Spring Quarry.

WSVP Weldon Spring vicinity properties.

Multiply by 0.037 to convert $\mathrm{pCi}$ to $\mathrm{Bq}$.

Multiply by 0.01 to convert mrem to $\mathrm{mSv}$.

Multiply by 0.01 to convert person-rem to person-Sv.

(a) A breathing rate of $1.2 \mathrm{~m}^{3} /$ hour is used for an adult male engaged in strenuous activity 


\subsubsection{Radiation Dose Equivalent From the Chemical Plant and Raffinate Pits to a Hypothetical Maximally Exposed Individual}

This section discusses the estimated TEDE to a hypothetical individual assumed to frequent the perimeter of the chemical plant and raffinate pits and receive a radiation dose by the exposure pathways identified above. No private residences are adjacent to the site. Therefore, all calculations of dose equivalent due to the applicable pathway of airborne radioactive particulate inhalation assume a realistic residence time that is less than $100 \%$. A full-time employee at the MHTD maintenance facility was considered to be the maximally exposed individual to releases of radionuclides from the chemical plant area.

The low and high volume samplers and radon detectors near the MHTD facility indicated no above-background concentrations of airborne radioactive particulates or radon gas. However, because the annual average environmental TLD result (Station TD-2004) exceeded background levels for the year, a dose estimate was calculated based on this measurement.

The exposure scenario assumptions are as follows:

- External exposure occurs to the maximally exposed individual while working outside the MHTD facility near the Weldon Spring Chemical Plant perimeter for a total of 2,000 hours per year.

- Net annual gamma exposure rate of $11 \mathrm{mrem} / \mathrm{year}$ (for continuous exposure), measured at TD-2004 at the northeastern boundary of the chemical plant. For 1997 , continuous exposure time is 8,760 hours.

Based on the exposure scenario and assumptions described above, a maximally exposed individual working at the MHTD facility received a total effective dose equivalent of $2.5 \mathrm{mrem}$ $(0.025 \mathrm{mSv})$ from external exposure.

\subsubsection{Radiation Dose From the Weldon Spring Quarry to a Hypothetical Maximally Exposed Individual}

This section discusses the estimated TEDE to a hypothetical individual assumed to frequent the perimeter of the Weldon Spring Quarry. The only private residence adjacent to the quarry site is monitored as a critical receptor, and all 1997 monitoring results indicated no above background exposure pathways. Therefore, all calculations of dose equivalent due to applicable pathways assume a realistic occupancy time of 5 hours/year, based on a hypothetical individual who hikes along the southeastern boundary of the quarry. The 5 hours/year assumption represents twice the value estimated for hikers at the Weldon Spring Conservation Area (Ref. 30). 
Exposure scenario assumptions particular to this dose calculation are as follows:

- No contribution from ingestion pathways was assumed because access to the quarry was controlled by 24 -hour security and a $2.4 \mathrm{~m}(8 \mathrm{ft})$ chain link fence topped with barbed wire. Fishing, swimming, and drinking water from the quarry pond were not considered to be realistic exposure pathways.

- Net Rn-220 concentration of $0.1 \mathrm{pCi} / 1$ (3.7E-3 Bq/1), measured at $\mathrm{RD}-1002$ at the quarry upper rim.

- $\mathrm{Rn}-220$ daughter equilibrium ratio of $0.5 \%$, based on historical measurements at the site.

- The individual hiked around the southeastern perimeter of the quarry 5 hours/year.

The total effective dose equivalent to the hypothetical maximally exposed individual at the quarry was $0.001 \mathrm{mrem}(0.01 \mu \mathrm{Sv})$ from inhalation of $\mathrm{Rn}-220$ daughters.

\subsubsection{Radiation Dose From Vicinity Properties to a Hypothetical Maximally Exposed Individual}

This section discusses the estimated total effective dose equivalent to a hypothetical individual assumed to frequent the Burgermeister Spring area of the Busch Memorial Conservation Area. This scenario provides a conservative but plausible exposure assessment. No private residences are adjacent to Burgermeister Spring (it is situated on land currently managed by the Missouri Department of Conservation [MDC]; therefore, the calculation of dose equivalent due to the applicable pathway of water ingestion (Liquid C) assumes a realistic occupancy time of one day per week. This scenario is based on a hypothetical individual who drank from Burgermeister Spring on a weekly basis in 1997.

Exposure scenario assumptions particular to this dose calculation include the following:

- Annual average radioactive particulate concentrations at the Busch Memorial Conservation Area were indistinguishable from background; therefore, no inhalation dose due to radioactive air particulates was calculated for an individual at Burgermeister Spring.

- No contribution to the estimated dose was included from radon or radon progeny concentrations associated with the Airborne (B) pathway, because annual alphatrack results in the area were at background levels. 
- No contribution to the estimated dose was included for the external pathway, because environmental TLD results at the Busch Memorial Conservation Area indicated background levels.

- Maximum radionuclide concentrations in water samples taken from Burgermeister Spring during 1997 (see Appendix B) were assumed to be present in the water ingested by the maximally exposed individual (MEI).

- Dose equivalent conversion factors for ingestion, as follows: total uranium, $2.69 \mathrm{E}-4 \mathrm{mrem} / \mathrm{pCi}$; Ra-226, $1.33 \mathrm{E}-3 \mathrm{mrem} / \mathrm{pCi}$; Ra-228, $1.44 \mathrm{E}-3 \mathrm{mrem} / \mathrm{pCi}$; Th-228, 3.96E-4 mrem/pCi; Th-230, 5.48E-4 mrem $/ \mathrm{pCi}$; and Th-232, 2.73E-3 mrem/pCi; Ra-224, 3.66E-4 mrem $/ \mathrm{pCi}$; and $\mathrm{Pb}-212,4.56 \mathrm{E}-5 \mathrm{mrem} / \mathrm{pCi}$ (Ref. 28).

The total effective dose equivalent to the maximally exposed individual at the vicinity properties from consumption of water from Burgermeister Spring was $0.46 \mathrm{mrem}(4.6 \mu \mathrm{Sv})$.

\subsubsection{Collective Population Dose}

This section discusses the estimated collective dose equivalent to the populations assumed to be exposed to radiation from the WSSRAP. Statistical testing at the $95 \%$ confidence level for all radioactive air particulate, radon gas, and gamma exposure measurements at critical receptor monitoring locations indicated that the only statistically significant results were for gamma radiation exposure at TD-2004 and radioactive air particulates at AP-2005. These stations are located along the northeast WSCP perimeter near the MHTD facility and at the WSSRAP administration building, respectively.

Measurements made by environmental thermoluminescent dosimeters (TLDs) indicated above background results of gamma exposure at the MHTD facility, necessitating the development of a general population exposure scenario. Also, the annual average radioactive airborne particulate concentration at low volume monitoring Station AP-2005 exceeded background levels for 1997. Thus, a second population exposure scenario was developed for employees at the WSSRAP administration building.

Another potential general population exposure is from the consumption of water, sediment, and fish from the August A. Busch Memorial Conservation Area. Two lakes at the conservation area receive runoff from the Weldon Spring site and are used for fishing and boating. Scenarios were developed and a dose assessment was performed for individuals potentially present at the MHTD facility, the WSSRAP Administration Building, and Lake 35 at the Busch Memorial Conservation Area in 1997. 
The scenario used for the Busch Memorial Conservation Area is based on recreational use for fishing, boating, and swimming activities. Only the ingestion pathways Liquid (B) and Liquid (C) were considered plausible for this assessment. Exposure scenario assumptions particular to this dose calculation are as follows:

- The MDC estimates that approximately 160,000 persons per year use the Busch Memorial Conservation Area (Ref. 30), which is adjacent to the chemical plant and raffinate pits area, while another 5,895 persons participate in recreational boating activities. Busch Lakes 34 and 35 receive runoff from the chemical plant and raffinate pits area, and both lakes are used for fishing and boating. Therefore, a population of 165,895 persons was assumed to have potential for exposure through ingestion of fish, water, and sediment from these lakes.

- The average time per fishing trip was 2.5 hours.

- The fish caught to time spent ratio is $0.4 \mathrm{fish} /$ hour, and the ratio of fish kept to fish caught is 0.5 . If each fish caught is consumed by a different person, the affected population would be 80,000 persons.

- The highest average total uranium concentration in a composite sunfish sample collected from Lake 35 in 1996 was 0.019 pCi/g (7.0E-4 Bq/g).

- The average time spent at the Busch Conservation Area per boating trip was approximately 5.7 hours (Ref. 30 ).

- Each of 5,895 visitors made only one visit to the area and spent $5 \%$ of the time swimming.

- Maximum water and sediment concentrations of total uranium were $10.4 \mathrm{pCi} / 1$ (0.39 Bq/1) (see Table 7-11) and $26.6 \mathrm{pCi} / \mathrm{g}(0.99 \mathrm{~Bq} / \mathrm{g}$ ), respectively (Ref. 59).

- No contribution from airborne pathways was included in the Busch Memorial Conservation Area dose estimates. Results from the measurements near the lakes indicated that there was no reason to suspect, at the $95 \%$ confidence level, that concentrations of airborne radioactive particulates or radon were greater than background levels.

For 1997, the estimated population dose equivalent for the Busch lakes scenario was 0.13 person-rem (1.3E-3 person-Sv). 
WELDON SPRING SITE ENVIRONMENTAL REPORT FOR CALENDAR YEAR 1997

$8 / 25 / 98$

The scenario used for the MHTD facility is the same as listed in Section 5.5.1. Assuming nine individuals work full-time at the facility, the collective population dose equivalent for the MHTD facility is 0.023 person-rem (2.3E-4 person-Sv).

The scenario for the WSSRAP Administration Building includes only inhalation of abovebackground concentrations of radionuclide as measured by low volume monitoring Station AP-2005 in 1997. The population at the Administration Building includes 300 employees who work an estimated 2,500 hours/year. Based on an annual net gross alpha concentration of $2.5 \mathrm{E}-16 \mu \mathrm{Ci} / \mathrm{ml}(9.25 \mathrm{E}-12 \mathrm{~Bq} / \mathrm{ml})$, and assuming that the only radionuclide of concern is total uranium, the collective population dose equivalent for employees at the Administration Building is 0.028 person-rem (2.8E-4 person-Sv).

The estimated total collective population dose equivalent from all three scenarios combined is 0.13 person-rem (1.3E-3 person-Sv) for 1997. Calculations are presented in Appendix B, Section D.

DOE/OR/21548-730, Rev. 0

71 


\section{NESHAPS PROGRAM}

This section provides information on 1997 annual atmospheric emissions of radionuclides, in accordance with the requirements of 40 CFR 61, Subpart H, National Emission Standards for Emissions of Radionuclides Other Than Radon From Department of Energy Facilities. Evaluations presented here include airborne emissions data and dose assessment and compliance information related to sources of radioactive particulate emissions at the Weldon Spring Site Remedial Action Project (WSSRAP).

\subsection{NESHAPs Monitoring and Dose Assessment Highlights}

- Results of National Emission Standards for Hazardous Air Pollutants (NESHAP) monitoring at the seven critical receptor monitoring locations indicated, at the $95 \%$ confidence level, no reason to suspect that annual average gross alpha or radioisotopic air particulate concentrations were greater than background levels.

- The highest dose assessment was for a maximally exposed individual residing continuously in the Francis Howell High School. Results indicated an annual committed effective dose equivalent (CEDE) of $0.18 \pm 0.41 \mathrm{mrem}(0.0018 \pm 0.0041 \mathrm{mSv})$ for this individual in 1997 .

- The 1997 collective population dose equivalent estimate for nine full-time employees of the Missouri Highway Transportation Department (MHTD), 300 employees at the WSSRAP, and 160,000 users of the Busch Memorial Conservation Area was 0.13 personrem (0.0013 person-Sv).

- Total Rn-220 emissions from the Weldon Spring site were estimated to be $42 \mathrm{Ci}$ (1.6E12 Bq) in 1997. Off-site Rn-222 emissions in 1997 were negligible.

\subsection{Facility Information}

\subsubsection{Site Description}

Specific information about the Weldon Spring site can be found in Section 1 of this report. 


\subsubsection{Source Description}

The Weldon Spring site is being remediated in accordance with the Comprehensive Environmental Response, Compensation, and Liability Act (CERCLA) and the National Environmental Policy Act (NEPA). It no longer operates as a uranium and thorium processing plant and has been in mothball status since about 1966. Therefore, radionuclides are no longer emitted from the original uranium processing plant sources (i.e., stacks, vents, or pipes described in 40 CFR 61, Subpart H).

Most airborne emissions of radionuclides at the Weldon Spring site result from wind dispersion of surface soils, temporary waste storage areas, or dust and dirt from building debris and fugitive dust generated during remedial actions. However, the site and quarry water treatment plants, as well as the chemical stabilization/solidification (CSS) facility when operational, constitute potential "point source" of radionuclide emissions other than radon. All on-site point emission sources that have the potential to emit radioactive airborne particulates are filtered using high efficiency particulate air (HEPA) exhaust systems.

The chemical plant buildings were contaminated with asbestos, hazardous chemical substances, and isotopes of uranium, radium, and thorium. (Building dismantlement was completed in 1994.) Concentrations in bulk samples collected from the buildings range from background levels to $20,000 \mathrm{pCi} / \mathrm{g} \mathrm{U}-238,190 \mathrm{pCi} / \mathrm{g} \mathrm{Ra}-226,5,400 \mathrm{pCi} / \mathrm{g} \mathrm{Ra}-228$, and $540 \mathrm{pCi} / \mathrm{g}$ Th-230 (Ref. 3). Radiological and chemical (i.e., polychlorinated biphenyls [PCBs], nitroaromatic compounds, and metals) contaminants can also be found in the soil in several areas around the site. Most of the 88 ha (217 acres) of the chemical plant area have above background concentrations of uranium $(>1 \mathrm{pCi} / \mathrm{g})$. Radionuclide concentrations range from $0.3 \mathrm{pCi} / \mathrm{g}$ to $2,259 \mathrm{pCi} / \mathrm{g} \mathrm{U}-238,0.2 \mathrm{pCi} / \mathrm{g}$ to $452 \mathrm{pCi} / \mathrm{g} \mathrm{Ra}-226,0.1 \mathrm{pCi} / \mathrm{g}$ to $155 \mathrm{pCi} / \mathrm{g} \mathrm{Ra}-228$ and $0.3 \mathrm{pCi} / \mathrm{g}$ to $123 \mathrm{pCi} / \mathrm{g}$ Th-230 (Ref. 21). During foundation and associated contaminated soil removal activities that were completed in July 1997 , approximately $471,730 \mathrm{cu} \mathrm{m}(617,000 \mathrm{cu}$ yd) of soil and rubble were removed to Ash Pond and the material staging area (MSA). As of the end of 1997, approximately 65 ha (160 acres) of 87 ha $(215$ acres) of soil have been remediated and wastes are stored in Ash Pond.

The raffinate pits are radiologically contaminated with uranium and thorium residues and chemical contaminants including nitrate, fluoride, $\mathrm{PCBs}$, and various heavy metals. Radionuclide concentrations found in raffinate pit sludge range from $<10$ to $3,400 \mathrm{pCi} / \mathrm{g}$ total uranium, $<8$ to $34,000 \mathrm{pCi} / \mathrm{g}$ Th-230, $<1$ to $1,700 \mathrm{pCi} / \mathrm{g} \mathrm{Ra}-226,<4$ to $1,400 \mathrm{pCi} / \mathrm{g} \mathrm{Th}-232,<4$ to $1,400 \mathrm{pCi} / \mathrm{g}$ $\mathrm{Ra}-228$, and $<3$ to $1,100 \mathrm{pCi} / \mathrm{g}$ Th-228 (Ref. 74). Raffinate Pit 4 sludge removal and consolidation activities were conducted during 1997. Prior to these activities, the raffinate pits were dewatered and debris within the pits was removed. Remediation of the northern portion of Raffinate Pit 4 also began in 1997. 
The quarry bulk waste located at the TSA, contains radiological and chemical contaminants including uranium, radium, thorium, metals, nitrates, PCBs, semivolatile organic compounds, nitroaromatics, and asbestos. The radionuclide concentrations range from 3.0 to $1,600 \mathrm{pCi} / \mathrm{g} \mathrm{U}-238,<1$ to $2,780 \mathrm{pCi} / \mathrm{g} \mathrm{Ra}-226,0.7$ to $36 \mathrm{pCi} / \mathrm{g} \mathrm{Th}-232,<1$ to $2,200 \mathrm{pCi} / \mathrm{g}$ $\mathrm{Ra}-228$, and $<1.0$ to $6,800 \mathrm{pCi} / \mathrm{g}$ Th-230 (Ref. 2). The quarry bulk waste was removed and placed at the temporary storage area (TSA) in 1995.

Overall, the airborne emissions of radionuclides at the WSSRAP are caused by two basic physical phenomena: (1) pulverization and abrasion of surface materials by application of mechanical force through implements (e.g., wheels, blades, etc.); and (2) entrainment of dust particles by the action of turbulent air currents, such as wind erosion of an exposed surface by wind speeds over $19 \mathrm{~km} / \mathrm{hr}(12 \mathrm{mph})$. The U.S. Environmental Protection Agency's Compilation of Air Pollutant Emission Factors (known as AP-42) documents emission factors for numerous industrial activities, including the use of heavy construction equipment typical of that used at the Weldon Spring Site Remedial Action Project (WSSRAP). These empirically-derived emission factors, which attempt to relate the quantity of a pollutant released to the atmosphere to the activity associated with the release of that pollutant, are ultimately used to predict downwind airborne pollutant concentrations at receptor locations. Emission rates, and subsequently downwind concentrations, depend on many assumed parameters, including soil characteristics, soil drop height, emissions control factors, meteorological measurements, road type, and vehicle characteristics (e.g., travel speed, number of wheels, weight), all of which contain a degree of uncertainty.

\subsection{Air Emission Data}

Based on the discussion in Section 6.2.2, Source Description, combining the assumed parameters with those included uncertainties and propagating them through Gaussian plume modeling to determine downwind airborne radionuclide concentrations results in conservatively large estimates of effective dose equivalent at receptor locations. Using the fugitive dust emission factors provided by the EPA, the amount of entrainment has been estimated for the emission sources at the WSSRAP to support engineering design studies; however, more accurate estimates of annual public effective dose equivalents are needed than can be realistically obtained using this method.

After evaluating the methods of assessing effective dose equivalents from radionuclide emissions from the Weldon Spring site, it was determined that monitoring air concentrations at critical receptors was the most accurate means of assessing effective dose equivalents to maximally exposed individuals. This alternative approach has been approved by EPA Region VII (Appendix A). The designation of the critical receptors and sampling procedures are described in Section 6.4.1. 
This section provides information regarding all of the point and non-point sources at the WSSRAP. Site radionuclide air emission data during the calendar year of 1997 are also reported.

\subsubsection{Point Sources}

Table 6-1 briefly describes the two chemical plant water treatment plants, the quarry water treatment plant, and the CSS pilot facility and lists their nearest receptor locations. Because critical receptor monitoring is performed at the WSSRAP, additional effluent monitoring under the requirements of 40 CFR 61 Subpart H and U.S. Department of Energy (DOE) Order 5400.5 is not required. In addition to critical receptor monitoring, engineering calculations have been performed to assess releases from the quarry and chemical plant water treatment plants and resulting dose equivalents to members of the public. These results indicate a dose equivalent of less than $0.1 \mathrm{mrem}(0.001 \mathrm{mSv})$ at the nearest receptor location as provided in Table 6-1.

Table 6-1

WSSRAP Point Sources

\begin{tabular}{|l|l|l|l|l|}
\hline & $\begin{array}{l}\text { EFFLUENT } \\
\text { CONTROL }\end{array}$ & $\begin{array}{l}\text { NEAREST } \\
\text { RECEPTOR }\end{array}$ & & \\
\hline POINT SOURCE ID & DESCRIPTION & EFFICIENCY & DESCRIPTION & DISTANCE \\
\hline Site Water Treatment Plant & $\begin{array}{l}\text { High Efficiency Air } \\
\text { Particulate (HEPA) } \\
\text { Filtered }\end{array}$ & $\begin{array}{l}99.97 \% \text { for } \\
0.3 \text { micron DOP* }\end{array}$ & $\begin{array}{l}\text { Administration } \\
\text { Building }\end{array}$ & $400 \mathrm{~m}$ \\
\hline $\begin{array}{l}\text { Quarry Water Treatment } \\
\text { Plant }\end{array}$ & $\begin{array}{l}\text { High Efficiency Air } \\
\text { Particulate (HEPA) } \\
\text { Filtered }\end{array}$ & $\begin{array}{l}99.97 \% \text { for } \\
0.3 \text { micron DOP }\end{array}$ & Residence & $700 \mathrm{~m}$ \\
\hline CSS Pilot Facility & $\begin{array}{l}\text { High efficiency air } \\
\text { particulate (HEPA) } \\
\text { fittered }\end{array}$ & $\begin{array}{l}99.97 \% \text { for 0.3 } \\
\text { micron DOP }\end{array}$ & $\begin{array}{l}\text { Administration } \\
\text { Building }\end{array}$ & $600 \mathrm{~m}$ \\
\hline
\end{tabular}

DOP - Dioctylphthalate

\subsubsection{Grouped Sources}

The WSSRAP has not defined any grouped sources.

\subsubsection{Non-Point Sources}

The WSSRAP primary sources for emissions are diffuse sources that at the most basic level consist of two areas, a chemical plant area and a quarry area. Due to the many different and constantly changing activities within these areas, the WSSRAP has chosen to monitor airborne concentrations at nearby critical receptor locations to demonstrate compliance with the NESHAPs standard. 
The quarry diffuse source is a 3.6 ha (9-acre) limestone quarry located approximately $6.4 \mathrm{~km}(4 \mathrm{mi})$ south-southwest of the chemical plant area. The quarry is essentially in a closed basin; surface water within the rim flows to the quarry floor and into a pond that covers approximately 0.07 ha $(0.2$ acre $)$. The quarry was used as a disposal area for dinitrotoluene (DNT) and trinitrotoluene (TNT) process wastes; uranium, radium, and thorium residues; the associated decay products from on-site and off-site processing of uranium and thorium; and building rubble and soils from the demolition of a uranium processing facility in St. Louis, Missouri. A major remediation project involving the removal and controlled temporary storage of approximately $110,000 \mathrm{~m}^{3}\left(144,000 \mathrm{yd}^{3}\right)$ of contaminated bulk waste was started in 1993 and completed at the end of 1995 . Residual radioactive contamination remains at the quarry and could be a potential source of airborne particulates.

The Weldon Spring Chemical Plant diffuse source encompasses 87 ha (215 acres) on which the Ash Pond storage area (APSA), four raffinate pits, the TSA, and the MSA are located. Airborne emissions from the chemical plant result from windblown resuspension of radioactive particulates from site soils and chemical plant building material and debris, and resuspension of radioactive particulates from site operations such as building foundation removal and soil excavation. During the foundation and contaminated soil removal activities, which was accomplished by July 1997 , approximately $303,528 \mathrm{cu} \mathrm{m}(397,000 \mathrm{cu}$ yd) of soil and rubble were removed and placed in Ash Pond. Approximately 168,202 cu m (220,000 cu yd) were removed to MSA. In addition, the nitroaromatically contaminated soils at the TSA were treated and stockpiled from October 1997 to February 1998. The strategy for all the above activities was to make efficient use of resources by minimizing the quantity of fine grain soil that was to be relocated, selecting equipment that will minimize dust generated during operations, limiting surface exposure of contaminated soils, and limiting hauling distances of all soils to a minimum. During 1997, no NESHAPs critical receptor monitors indicated radioactive air particulate concentrations statistically greater than background levels.

\subsubsection{Net Measured Radionuclide Concentrations}

Based on the sample analyses results obtained from the critical receptors, net measured concentrations for each radionuclide during each quarter are listed in Table 6-2, and the yearly averages are compared to the limiting levels listed in Subpart H of 40 CFR 61, Appendix E, Table 2 .

The sum of the fractions obtained from dividing each radionuclide concentration by the listed NESHAPs limit is minus $1.13 \%$. The negative value is caused by subtracting the annual average background concentrations of each specified radionuclide and, therefore, demonstrates that the net measured concentrations around the WSSRAP are comparable with the background concentration level. 
Table 6-2 Net Concentrations and Comparison

\begin{tabular}{|c|c|c|c|c|c|c|c|}
\hline & \multicolumn{4}{|c|}{ QUARTERLY AVERAGE ${ }^{\star \star}\left(\mu \mathrm{Ci} / \mathrm{m}^{3}\right)$} & \multirow[b]{2}{*}{$\begin{array}{l}\text { YEARLY } \\
\text { AVERAGE } \\
\left(\mathrm{Ci} / \mathrm{m}^{3}\right)\end{array}$} & \multirow[b]{2}{*}{$\begin{array}{c}\text { NESHAPS } \\
\text { LIMIT* } \\
\left(\mathrm{Ci} / \mathrm{m}^{3}\right) \\
\end{array}$} & \multirow[b]{2}{*}{$\begin{array}{c}\text { PRECENT } \\
\text { OF LIMIT } \\
(\%)\end{array}$} \\
\hline RADIONUCLIDES & $\begin{array}{c}\text { 1ST } \\
\text { QUARTER }\end{array}$ & $\begin{array}{c}\text { 2ND } \\
\text { QUARTER }\end{array}$ & $\begin{array}{c}\text { 3RD } \\
\text { QUARTER }\end{array}$ & $\begin{array}{c}\text { 4TH } \\
\text { QUARTER }\end{array}$ & & & \\
\hline $\mathrm{U}-238$ & $9.04 \mathrm{E}-18$ & $9.98 \mathrm{E}-18$ & $3.11 \mathrm{E}-17$ & $1.84 \mathrm{E}-17$ & $1.71 \mathrm{E}-17$ & $8.30 \mathrm{E}-15$ & 0.21 \\
\hline $\mathrm{U}-234$ & $9.13 \mathrm{E}-18$ & $1.01 \mathrm{E}-17$ & $3.14 \mathrm{E}-17$ & $1.86 \mathrm{E}-17$ & $1.69 \mathrm{E}-17$ & $7.70 \mathrm{E}-15$ & 0.22 \\
\hline Ra-226 & $3.09 E-18$ & $7.38 \mathrm{E}-18$ & $9.62 E-18$ & $2.67 \mathrm{E}-17$ & $1.17 \mathrm{E}-17$ & $3.30 \mathrm{E}-15$ & 0.35 \\
\hline Ra-228 & $-6.6 \mathrm{E}-19$ & $-2.4 \mathrm{E}-17$ & $1.83 E-17$ & $\sim$ & $-2 E-18$ & $5.90 \mathrm{E}-15$ & -0.03 \\
\hline Th-228 & $1.3 E-18$ & $3.1 \mathrm{E}-19$ & $5.88 E-17$ & $-3.8 \mathrm{E}-17$ & $5.56 \mathrm{E}-18$ & $3.10 \mathrm{E}-15$ & 0.18 \\
\hline Th-230 & $1.74 \mathrm{E}-18$ & $1.05 \mathrm{E}-17$ & $2.96 \mathrm{E}-17$ & $-2.67 E-17$ & $3.79 E-18$ & $3.40 \mathrm{E}-15$ & 0.11 \\
\hline Th-232 & $2.09 \mathrm{E}-19$ & $3.87 \mathrm{E}-19$ & $-2.4 E-17$ & $-3.03 E-17$ & $-1.3 \mathrm{E}-17$ & $6.20 \mathrm{E}-16$ & -2.17 \\
\hline & & & & & & $\overline{\text { TOTAL }}$ & -1.13 \\
\hline
\end{tabular}

* Regulated net measured concentrations for each nuclide in 40 CFR 61, Subpart $H$, Appendix E, Table 2.

* Background concentrations have been subtracted from the gross radionuclide concentration values.

$\sim \quad$ Indicate rejected erroneous data.

Multiply $3.7 \mathrm{E} 10$ to convert $\mu \mathrm{Ci} / \mathrm{m}^{3}$ to $\mathrm{Bq} / \mathrm{m}^{3}$

\subsection{Dose Assessment}

Due to the uncertainties associated with modeling airborne radionuclide emissions resulting from radioactive sources at the Weldon Spring site, the WSSRAP has chosen a more reliable method of critical receptor monitoring. To demonstrate compliance with applicable standards, these critical receptor locations are places where members of the public abide or reside and have a potential to encounter off-site concentrations of radioactive airborne particulates during WSSRAP remediation activities. The critical receptor monitoring methodology is described in the WSSRAP Plan for Monitoring Radionuclide Emissions Other Than Radon at Weldon Spring Site Critical Receptors (Ref. 21), which has been approved by EPA Region VII.

\subsubsection{Sampling Procedure}

As mentioned in Section 3.2.1.1 of this report, seven designated critical receptor locations surrounding the Weldon Spring site have been selected in order to achieve compliance with NESHAPs requirements. The seven locations were selected based on their proximity to the site (less than $1 \mathrm{~km}[0.62 \mathrm{mi}]$ ) and the probability that members of the public would spend at least 8 hours per day near them. The seven critical receptor locations and the background monitoring location are shown in Figure 6-1 and are described in Table 6-3. They include: the common boundary of the Weldon Spring Chemical Plant and the Missouri Highway and Transportation Department (MHTD) maintenance facility (AP-2001); the WSSRAP administration building (AP-2005); Francis Howell High School (AP-4006); the August A. Busch Memorial Conservation Area (AP-4007); the Weldon Spring Training Area on the Department of the Army property (AP-4008); $150 \mathrm{~m}(0.1 \mathrm{mi})$ from the residence nearest to the quarry (AP-4011), and a 


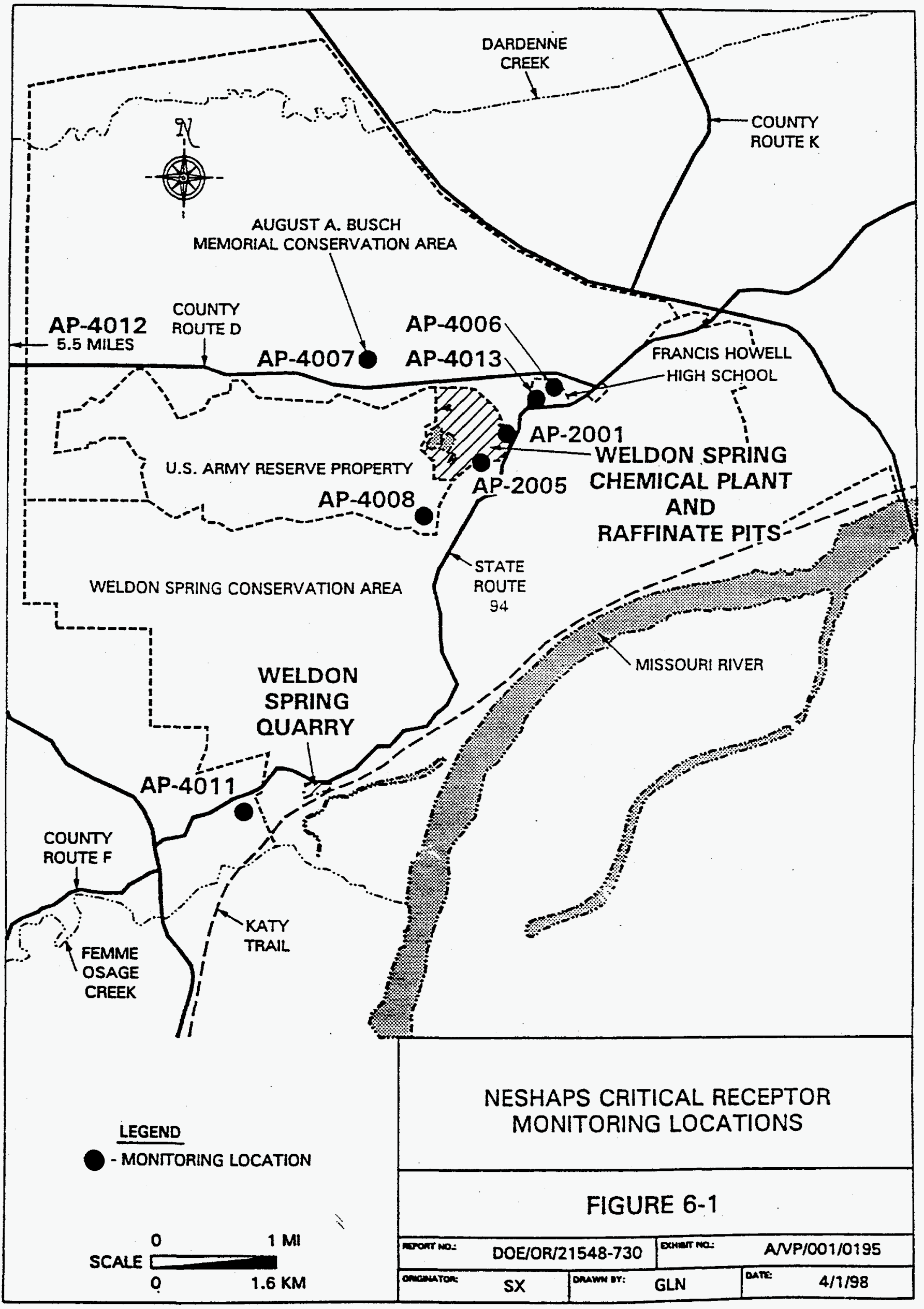


Table 6-3 Exposure Scenarios and NESHAPs Dose Estimates for 1997

\begin{tabular}{|l|l|c|c|c|}
\hline \multicolumn{1}{|c|}{ CRITICAL RECEPTOR } & SAMPLE ID & TOTAL INDIVIDUALS & EXPOSURE DURATION & $\begin{array}{c}\text { ESTIMATED DOSE EQUIVALENT } \\
\text { (mrem)/PERSON }\end{array}$ \\
\hline MHTD facility & AP-2001 & 9 & $2,000 \mathrm{hr} / \mathrm{yr}$ & $0.08 \pm 0.11$ \\
\hline WSSRAP administration building & AP-2005 & 300 & $2,250 \mathrm{hr} / \mathrm{yr}$ & $0.04 \pm 0.12$ \\
\hline Francis Howell High School - Assessment 1 & AP-4006 & 2,030 & $2,250 \mathrm{hr} / \mathrm{yr}$ & $0.05 \pm 0.11$ \\
\hline Francis Howell High School - Assessment 2 & AP-4006 & $1^{(a)}$ & $8,760 \mathrm{hr} / \mathrm{yr}$ & $0.18 \pm 0.41$ \\
\hline Busch Memorial Conservation Area & AP-4007 & 40 & $2,500 \mathrm{hr} / \mathrm{yr}$ & $0.08 \pm 0.15$ \\
\hline Weldon Spring Training Area - Assessment & AP-4008 & $1^{(5)}$ & $2,000 \mathrm{hr} / \mathrm{yr}$ & $0.05 \pm 0.11$ \\
\hline Nearest quarry residence & AP-4011 & $3^{(\mathrm{cr}}$ & $8,760 \mathrm{hr} / \mathrm{yr}$ & $0.03 \pm 0.40$ \\
\hline Francis Howell High School Annex & AP-4013 & 38 & $2,050 \mathrm{hr} / \mathrm{yr}$ & $0.04 \pm 0.30$ \\
\hline
\end{tabular}

(a) One individual residing full-time on school properties.

(b) One employee working full-time on Army property.

(c) Three individual per household.

hr/yr Hours per year.

Multiply by 0.01 to convert mrem to $\mathrm{mSv}$. 
newly installed station at the Francis Howell High School Annex (AP-4013). Daniel Boone Elementary School in New Melle, Missouri, is the designated background monitoring location (AP-4012). Technically, the WSSRAP administration building is considered an on-site receptor rather than a critical receptor because its occupants are not members of the general public, and the area is under DOE control. However, for reporting purposes, it is referred to as a "critical receptor."

Each critical receptor location includes a low volume air particulate sampler $(\sim 40 \mathrm{lpm})$ and a high volume air sampler $(\sim 950 \mathrm{lpm})$. Low volume samples are collected on mixed cellulose ester membrane filters approximately $1.5 \mathrm{~m}(5 \mathrm{ft})$ above the ground, and are exchanged and analyzed on a weekly basis. High volume samples are collected on large glass fiber filters approximately $1.2 \mathrm{~m}(4 \mathrm{ft})$ above the ground, which are also exchanged weekly but imported and analyzed quarterly. It is the high volume sampling results that are used to demonstrate NESHAPs compliance at the WSSRAP.

At the beginning of each calendar quarter, the high volume filters collected over the previous quarter are composited to form eight distinct samples, one for each critical receptor location and background station. The high volume samples are analyzed for isotopic thorium, total uranium, Ra-226, and Ra-228. For reporting purposes, the background concentrations are subtracted from each sample concentration. If background concentrations are greater than the concentration of the critical receptor sample, a negative net concentration is reported.

\subsubsection{Compliance Assessment}

Based on the results of the high volume samples, a realistic exposure scenario and dose estimate was developed for each of the seven critical receptor locations. The assumptions made for the dose estimates include:

- Breathing rate of $1.2 \mathrm{~m}^{3} /$ hour $\left(42.4 \mathrm{ft}^{3} /\right.$ hour $)$ provided in $10 \mathrm{CFR} 20$, Standards for Protection Against Radiation.

- 50-year committed effective dose equivalent conversion factors provided in EPA Federal Guidance Report No. 11 (Ref. 28);

- Exposure duration listed in Table 6-3

NESHAPs isotopic air monitoring results and the calculated effective dose equivalent for each critical receptor are listed in Table 6-4, with the exception of Ra-228 for fourth quarter 1997. These results, as shown in the table, were rejected because of the reported erroneous data, which was caused by chemical interference in the laboratory analytical process. Therefore, 
Table 6-4 NESHAPs Isotopic Air Monitoring Results with Effective Dose Equivalent Contributions, 1997

\begin{tabular}{|c|c|c|c|c|c|c|c|c|c|}
\hline AP.2001 & \multicolumn{2}{|c|}{ 1st QUARTER } & \multicolumn{2}{|c|}{ 2nd QUARTER } & \multicolumn{2}{|c|}{ 3rd QUARTER } & \multicolumn{2}{|c|}{ 4th QUARTER } & \multirow[b]{2}{*}{$\begin{array}{c}\text { ANNUAL } \\
\text { EFFECTIVE } \\
\text { DOSE } \\
\text { EQUIVALENT } \\
\text { (mrem) }\end{array}$} \\
\hline RADIONUCLIDE & $\begin{array}{c}\text { NET } \\
\text { CONCENTRATON } \\
\left(\mu \mathrm{Ci} / \mathrm{m}^{3}\right)\end{array}$ & $\begin{array}{l}\text { EFFECTIVE } \\
\text { DOSE } \\
\text { EQUIVALENT } \\
\text { (mrem) }\end{array}$ & $\begin{array}{c}\text { NET CONCENTRATON } \\
\left(\mu \mathrm{C} / \mathrm{m}^{3}\right)\end{array}$ & $\begin{array}{l}\text { EFFECTIVE } \\
\text { DOSE } \\
\text { EQUIVALENT } \\
\text { (mrem) }\end{array}$ & $\begin{array}{c}\text { NET CONCENTRATON } \\
\left(\mu \mathrm{C} / \mathrm{m}^{3}\right)\end{array}$ & $\begin{array}{l}\text { EFFECTIVE } \\
\text { DOSE } \\
\text { EQUIVALENT } \\
\text { (mrem) }\end{array}$ & $\begin{array}{c}\text { NET CONCENTRATON } \\
\left(\mu \mathrm{C} / \mathrm{m}^{3}\right)\end{array}$ & $\begin{array}{l}\text { EFFECTIVE DOSE } \\
\text { EQUIVALENT } \\
\text { (mrem) }\end{array}$ & \\
\hline Totalu & $1.01 \mathrm{E}-10 \pm \mathrm{N} / \mathrm{A}$ & $0.0061 \pm N / A$ & $5.09 E-11 \pm N / A$ & $0.0031 \pm N / A$ & $1.27 E-10 \pm N / A$ & $0.0076 \pm N / A$ & $3.61 \mathrm{E}-11 \pm \mathrm{N} / \mathrm{A}$ & $0.0022+N / A$ & $0.0190 \pm N / A$ \\
\hline Ra-226 & $1.66 \mathrm{E}-11 \pm 2.02 \mathrm{E}-11$ & $0.0001 \pm 0.0001$ & $9.89 \mathrm{E}-12+1.37 \mathrm{E}-11$ & $0 \pm 0.0001$ & $5.64 \mathrm{E}-12+1.41 \mathrm{E}-11$ & $0 \pm 0.0001$ & $7.66 \mathrm{E}-12+1.26 \mathrm{E}-11$ & $0 \pm 0.0001$ & $0.0001 \pm 0.0002$ \\
\hline Ra-228 & $3.05 E-12 \pm 1.07 E-10$ & $0 \pm 0.0002$ & $-1.91 \mathrm{E}-11 \pm 6.91 \mathrm{E}-11$ & $0 \pm 0.0002$ & $4.49 \mathrm{E}-11 \pm 6.53 \mathrm{E}-11$ & $0.0001 \pm 0.0001$ & - & - & $0.0001 \pm 0.0003$ \\
\hline Th.228 & $1.73 E-12+5.93 E-12$ & $0.0003 \pm 0.0010$ & $3.14 \mathrm{E}-11 \pm 2.33 \mathrm{E}-11$ & $0.0051 \pm 0.0038$ & $8.63 \mathrm{E}-11 \pm 1.76 \mathrm{E}-10$ & $0.0141 \pm 0.0288$ & $-4.52 E-11 \pm 7.24 E-11$ & $0 \pm 0.0119$ & $0.0195 \pm 0.0314$ \\
\hline Th-230 & $2.62 E-12 \pm 5.50 E-12$ & $0.0004 \pm 0.0009$ & $6.78 E-11 \pm 8.49 E-12$ & $0.0106 \pm 0.0013$ & $9.79 \mathrm{E}-11 \pm 1.52 \mathrm{E}-10$ & $0.0153 \pm 0.0238$ & $-3.32 E-11 \pm 7.61 E-11$ & $0 \pm 0.0119$ & $0.0263 \pm 0.0267$ \\
\hline Th-232 & $1.17 \mathrm{E}-13 \pm 1.69 \mathrm{E}-12$ & $0.0001 \pm 0.0013$ & $2.31 \mathrm{E}-11 \pm 7.50 \mathrm{E}-12$ & $0.0182+0.0059$ & $-9.83 E-12+1.08 E-10$ & $0 \pm 0.0848$ & $-4.76 \mathrm{E}-11 \pm 7.02 \mathrm{E}-11$ & $0 \pm 0.0553$ & $0.0183 \pm 01014$ \\
\hline EDE & \multirow{2}{*}{\multicolumn{2}{|c|}{$\frac{0.0070 \pm 0.0019}{\text { 1st QUARTER }}$}} & \multirow{2}{*}{\multicolumn{2}{|c|}{$\begin{array}{l}0.0371 \pm 0.0072 \\
\text { 2nd QUARTER }\end{array}$}} & & $0.0371 \pm 0.0927$ & & $0.0022+0.0578$ & $0.0832+0.1095$ \\
\hline AP.2005 & & & & & \multicolumn{2}{|c|}{ 3rd QUARTER } & \multicolumn{2}{|c|}{ 4h QUARTER } & ANNUAL \\
\hline RADIONUCLIDE & $\begin{array}{c}\text { NET } \\
\text { CONCENTRATON } \\
\left(\mu \mathrm{Ci} / \mathrm{m}^{3}\right)\end{array}$ & $\begin{array}{l}\text { EFFECTIVE } \\
\text { DOSE } \\
\text { EQUIVALENT } \\
\text { (mrem) }\end{array}$ & $\begin{array}{c}\text { NET CONCENTRATON } \\
\left(\mu \mathrm{Ci} / \mathrm{m}^{3}\right)\end{array}$ & $\begin{array}{l}\text { EFFECTIVE } \\
\text { DOSE } \\
\text { EQUIVALENT } \\
\text { (mrem) }\end{array}$ & $\begin{array}{l}\text { NET CONCENTRATON } \\
\left(\mu \mathrm{Ci} / \mathrm{m}^{3}\right)\end{array}$ & $\begin{array}{l}\text { EFFECTIVE } \\
\text { DOSE } \\
\text { EQUIVALENT } \\
\text { (mrem) }\end{array}$ & $\begin{array}{c}\text { NET CONCENTRATON } \\
\left(\mu \mathrm{Ci} / \mathrm{m}^{3}\right)\end{array}$ & $\begin{array}{l}\text { EFFECTIVE DOSE } \\
\text { EQUIVALENT } \\
\text { (mrem) }\end{array}$ & $\begin{array}{l}\text { EFFECTIVE } \\
\text { DOSE } \\
\text { EQUIVALENT } \\
\text { (mrem) }\end{array}$ \\
\hline TolalU & $-493 E-11 \pm N / A$ & $0 \pm N / A$ & $5.28 \mathrm{E}-11 \pm \mathrm{N} / \mathrm{A}$ & $0.0040 \pm N / A$ & $1.14 E-10 \pm N / A$ & $0.0086 \pm N / A$ & $2.77 \mathrm{E}-11 \pm N / \mathrm{A}$ & $0.0021 \pm N / A$ & $0.0147 \pm N / A$ \\
\hline Ra-226 & $3.73 E-12 \pm 1.61 E-11$ & $0 \pm 0.0001$ & $9.27 \mathrm{E}-12 \pm 1.50 \mathrm{E}-11$ & $0 \pm 0.0001$ & $6.31 \mathrm{E}-12+1.36 \mathrm{E}-11$ & $0 \pm 0.0001$ & $1.56 \mathrm{E}-11 \pm 1.51 \mathrm{E}-11$ & $0.0001 \pm 0.0001$ & $0.0001 \pm 0.0002$ \\
\hline Ra-228 & $6.93 \mathrm{E}-13 \pm 9.04 \mathrm{E}-11$ & $0 \pm 0.0003$ & $-2.20 \mathrm{E}-11 \pm 7.39 \mathrm{E}-11$ & $0 \pm 0.0002$ & $3.37 \mathrm{E}-12+6.18 \mathrm{E}-11$ & $0 \pm 0.0002$ & - & - & $0 \pm 0.0004$ \\
\hline Th-228 & $7.58 \mathrm{E}-13 \pm 6.37 \mathrm{E}-12$ & $0.0002 \pm 0.0013$ & $7.66 \mathrm{E}-12 \pm 1.95 \mathrm{E}-11$ & $0.0016 \pm 0.0040$ & $3.54 \mathrm{E}-11 \pm 1.54 \mathrm{E}-10$ & $0.0073 \pm 0.0316$ & $-5.08 \mathrm{E}-11 \pm 7.38 \mathrm{E}-11$ & $0 \pm 0.0151$ & $0.0091 \pm 0.0355$ \\
\hline Th-230 & $1.91 \mathrm{E}-12 \pm 5.98 \mathrm{E}-12$ & $0.0004 \pm 0.0012$ & $4.33 \mathrm{E}-11 \pm 7.06 \mathrm{E}-12$ & $0.0085 \pm 0.0014$ & $-3.51 E-11 \pm 1.40 E-10$ & $0 \pm 0.0273$ & $-2.99 \mathrm{E}-11 \pm 8.00 \mathrm{E}-11$ & $0 \pm 0156$ & $0.0089+0.0315$ \\
\hline Th-232 & $7.00 E-14 \pm 1.79 E-12$ & $0.0001 \pm 0.0018$ & $8.92 \mathrm{E}-12+6.65 \mathrm{E}-12$ & $0.0088 \pm 0.0065$ & $-7.53 \mathrm{E}-11 \pm 8.87 \mathrm{E}-11$ & $0 \pm 0.0872$ & $-4.09 \mathrm{E}-11 \pm 7.51 \mathrm{E}-11$ & $0 \pm 0.0739$ & $0.0089 \pm 0.1145$ \\
\hline & \multirow{2}{*}{\multicolumn{2}{|c|}{$0.0007 \pm 0.0025$}} & \multirow{2}{*}{\multicolumn{2}{|c|}{$0.0229 \pm 0.0078$}} & \multirow{2}{*}{\multicolumn{2}{|c|}{$0.0159 \pm 0.0967$}} & \multirow{2}{*}{\multicolumn{2}{|c|}{$0.0022+0.0770$}} & $0.0417 \pm 0.1239$ \\
\hline AP-4006 (I) & & & & & & & & & ANNNUAL \\
\hline RADIONUCLIDE & $\begin{array}{c}\text { NET } \\
\text { CONCENTRATON } \\
\left(\mu \mathrm{Ci} / \mathrm{m}^{3}\right)\end{array}$ & $\begin{array}{l}\text { EFFECTIVE } \\
\text { DOSE } \\
\text { EQUIVALENT } \\
\text { (mrem) }\end{array}$ & $\begin{array}{c}\text { NET CONCENTRATON } \\
\left(\mu \mathrm{Ci} / \mathrm{m}^{3}\right)\end{array}$ & $\begin{array}{l}\text { EFFECTIVE } \\
\text { DOSE } \\
\text { EQUIVALENT } \\
\text { (mrem) }\end{array}$ & $\begin{array}{l}\text { NET CONCENTRATON } \\
\left(\mu \mathrm{C} / \mathrm{m}^{3}\right)\end{array}$ & $\begin{array}{l}\text { EFFECTIVE } \\
\text { DOSE } \\
\text { EQUIVALENT } \\
\text { (mrem) }\end{array}$ & $\begin{array}{c}\text { NET CONCENTRATON } \\
\left(\mu \mathrm{C} / \mathrm{m}^{3}\right)\end{array}$ & $\begin{array}{l}\text { EFFECTIVE DOSE } \\
\text { EQUIVALENT } \\
\text { (mrem) }\end{array}$ & $\begin{array}{l}\text { EFFECTIVE } \\
\text { DOSE } \\
\text { EQUVIVALENT } \\
\text { (mrem) }\end{array}$ \\
\hline TotalU & $-5.74 \mathrm{E}-11 \pm N / A$ & $0 \pm N / A$ & $9.40 \mathrm{E}-12+\mathrm{N} / \mathrm{A}$ & $0.0006 \pm N / A$ & $-4.45 E-11 \pm N / A$ & $O \pm N A A$ & $2.63 E-11 \pm N / A$ & $0.0018 \pm N / A$ & $0.0024 \pm \mathrm{N} / \mathrm{A}$ \\
\hline Ra-226 & $1.49 \mathrm{E}-12+1.57 \mathrm{E}-11$ & $0 \pm 0.0001$ & $-202 \mathrm{E}-11 \pm 1.70 \mathrm{E}-11$ & $0 \pm 0.0001$ & $1.94 \mathrm{E}-11 \pm 1.68 \mathrm{E}-11$ & $0.0001 \pm 0.0001$ & $2.19 \mathrm{E}-11 \pm 1.89 \mathrm{E}-11$ & $0.0001 \pm 0.0001$ & $0.0002+0.0002$ \\
\hline Ra-228 & $-1.64 \mathrm{E}-12+8.44 \mathrm{E}-11$ & $0 \pm 0.0002$ & $-2.38 \mathrm{E}-11 \pm 884 \mathrm{E}-11$ & $0 \pm 0.0002$ & $7.25 \mathrm{E}-11 \pm 7.31 \mathrm{E}-11$ & $0.0002+0.0002$ & $\sim$ & $\sim$ & $0.0002+0.0003$ \\
\hline Th-228 & $9.22 \mathrm{E}-13 \pm 7.65 \mathrm{E}-12$ & $0.0002 \pm 0.0014$ & $1.96 \mathrm{E}-11 \pm 5.64 \mathrm{E}-11$ & $0.0036 \pm 00101$ & $592 \mathrm{E}-11 \pm 1.47 \mathrm{E}-10$ & $0.0110 \pm 0.0270$ & $-3.96 \mathrm{E}-11 \pm 6.82 \mathrm{E}-11$ & $0 \pm 0.0126$ & $0.0148 \pm 0.0315$ \\
\hline Th-230 & $8.27 E-13 \pm 5.9 E-12$ & $0.0001 \pm 0.0010$ & $5.01 E-11 \pm 8.63 E-12$ & $0.0088 \pm 0.0015$ & $1.63 \mathrm{E}-11 \pm 1.36 \mathrm{E}-10$ & $0.0029 \pm 0.0239$ & $-3.66 \mathrm{E}-11 \pm 6.94 \mathrm{E}-11$ & $0 \pm 0.0122$ & $0.0118 \pm 0.0269$ \\
\hline Th-232 & $-1.15 E-13 \pm 1.92 E-12$ & $0 \pm 0.0017$ & $1.95 \mathrm{E}-11 \pm 5.66 \mathrm{E}-12$ & $0.0173 \pm 0.0050$ & $-4.11 \mathrm{E}-11 \pm 8.80 \mathrm{E}-11$ & $0+0.0779$ & $-3.80 \mathrm{E}-11 \pm 6.72 \mathrm{E}-11$ & $0 \pm 0.0602$ & $0.0173 \pm 0.0992$ \\
\hline EDE & & $0.0003 \pm 0.0025$ & & $0.0303 \pm 0.0117$ & & $0.0142+0.0859$ & & $0.0019 \pm 0.0704$ & $0.0467 \pm 0.1067$ \\
\hline
\end{tabular}


Table 6-4 NESHAPs Isotopic Air Monitoring Results with Effective Dose Equivalent Contributions, 1997 (Continued)

\begin{tabular}{|c|c|c|c|c|c|c|c|c|c|}
\hline AP- $4006^{(2)}$ & \multicolumn{2}{|c|}{ ist QUARTER } & \multicolumn{2}{|c|}{ 2nd QUARTER } & \multicolumn{2}{|c|}{ 3rd QUARTER } & \multicolumn{2}{|c|}{ 4th QUARTER } & \multirow{2}{*}{$\begin{array}{c}\text { ANNUAL } \\
\text { EFFECTIVE } \\
\text { DOSE } \\
\text { EQUIVALEN } \\
\text { (mrem) }\end{array}$} \\
\hline RADIONUCLIDE & $\begin{array}{c}\text { NET } \\
\text { CONCENTRATON } \\
\left(\mu \mathrm{Ci} / \mathrm{m}^{3}\right)\end{array}$ & $\begin{array}{l}\text { EFFECTIVE } \\
\text { DOSE } \\
\text { EQUNALENT } \\
\text { (mrem) }\end{array}$ & $\begin{array}{l}\text { NET CONCENTRATON } \\
\left(\mu \mathrm{C} / \mathrm{m}^{3}\right)\end{array}$ & $\begin{array}{l}\text { EFFECTIVE } \\
\text { DOSE } \\
\text { EQUIVALENT } \\
\text { (mrem) }\end{array}$ & $\begin{array}{c}\text { NET } \\
\text { CONCENTRATON } \\
\left(\mu \mathrm{Ci} / \mathrm{m}^{3}\right)\end{array}$ & $\begin{array}{l}\text { EFFECTIVE DOSE } \\
\text { EQUIVALENT } \\
\text { (mrem) }\end{array}$ & $\begin{array}{c}\text { NET CONCENTRATON } \\
\left(\mu \mathrm{Ci} / \mathrm{m}^{3}\right)\end{array}$ & $\begin{array}{l}\text { EFFECTIVE } \\
\text { DOSE } \\
\text { EQUIVALENT } \\
\text { (mrem) }\end{array}$ & \\
\hline TolalU & $-5.74 E-11 \pm N / A$ & $0 \pm N / A$ & $9.4 E-12+N / A$ & $0.0025 \pm N / A$ & $-4.45 E-11 \pm N / A$ & $0 \pm N / A$ & $2.63 \mathrm{E}-11 \pm \mathrm{N} / \mathrm{A}$ & $0.0069 \pm N / A$ & $0.0094 \pm N / A$ \\
\hline$R a-226$ & $1.49 \mathrm{E}-12+1.57 \mathrm{E}-11$ & $0 \pm 0.0003$ & $2.02 E-11 \pm 1.7 E-11$ & $0.0004 \pm 0.0003$ & $1.94 \mathrm{E}-11 \pm 1.68 \mathrm{E}-11$ & $0.0004 \pm 0.0003$ & $2.19 \mathrm{E}-11 \pm 1.89 \mathrm{E}-11$ & $0.0004 \pm 0.0003$ & $0.0012+0.0006$ \\
\hline $\mathrm{Ra}-228$ & $-1.64 E-12+8.44 E-11$ & $0 \pm 0.0009$ & $-2.38 \mathrm{E}-11 \pm 8.84 \mathrm{E}-11$ & $0 \pm 0.0009$ & $7.25 E-11 \pm 7.31 E-11$ & $0.0007 \pm 0.0007$ & $\sim$ & $\sim$ & $0.0007 \pm 0.0015$ \\
\hline Th-228 & $9.22 \mathrm{E}-13 \pm 7.65 \mathrm{E}-12$ & $0.0007 \pm 0.0055$ & $1.96 E-11 \pm 5.64 E-11$ & $0.0141 \pm 0.0405$ & $5.92 \mathrm{E}-11 \pm 1.47 \mathrm{E}-10$ & $0.0425 \pm 0.1054$ & $-3.96 \mathrm{E}-11 \pm 6.82 \mathrm{E}-11$ & $0 \pm 0.0450$ & $0.0573+0.1217$ \\
\hline Th-230 & $8.27 \mathrm{E}-13+5.9 \mathrm{E}-12$ & $0.0006 \pm 0.0040$ & $5.01 \mathrm{E}-11 \pm 8.63 \mathrm{E}-12$ & $0.0343 \pm 0.0059$ & $1.63 E-11 \pm 1.36 \mathrm{E}-10$ & $0.0112+0.0932$ & $-3.66 \mathrm{E}-11 \pm 6.94 \mathrm{E}-11$ & $0 \pm 0.0475$ & $0.0461 \pm 0.1048$ \\
\hline Th-232 & $-1.15 \mathrm{E}-13 \pm 1.95 \mathrm{E}-12$ & $0 \pm 0.0067$ & $1.95 \mathrm{E}-11 \pm 5.66 \mathrm{E}-12$ & $0.0673 \pm 0.0195$ & $-4.11 E-11 \pm 8.80 E-11$ & $0 \pm 0.3032$ & $-3.80 \mathrm{E}-11 \pm 6.72 \mathrm{E}-11$ & $0 \pm 0.2317$ & $0.0673 \pm 0.3822$ \\
\hline EDE & \multirow{2}{*}{\multicolumn{2}{|c|}{$\begin{array}{c}0.0013 \pm 0.0096 \\
\text { 1sI QUARTER }\end{array}$}} & \multirow{2}{*}{\multicolumn{2}{|c|}{$\begin{array}{r}0.1186 \pm 0.0454 \\
0.12\end{array}$}} & \multirow{2}{*}{\multicolumn{2}{|c|}{$\begin{array}{c}0.0548 \pm 0.33431 \\
\text { 3rd QUARTER }\end{array}$}} & & $0.0073 \pm 0.2408$ & $0.182+0.4146$ \\
\hline AP-4007 & & & 2nd QUAR & & & & \multicolumn{2}{|c|}{$\begin{array}{l}0.0073 \pm 0.2408 \\
\text { 4th QUARTER }\end{array}$} & ANNUAL \\
\hline RADIONUCLIDE & $\begin{array}{c}\text { NET } \\
\text { CONCENTRATON } \\
\left(\mu \mathrm{Ci} / \mathrm{m}^{3}\right)\end{array}$ & $\begin{array}{l}\text { EFFECTIVE } \\
\text { DOSE } \\
\text { EQUIVALENT } \\
\text { (mrem) }\end{array}$ & $\begin{array}{c}\text { NET CONCENTRATON } \\
\left(\mu \mathrm{C} / \mathrm{m}^{3}\right)\end{array}$ & $\begin{array}{c}\text { EFFECTIVE } \\
\text { DOSE } \\
\text { EQUIVALENT } \\
\text { (mrem) }\end{array}$ & $\begin{array}{c}\text { NET } \\
\text { CONCENTRATON } \\
\left(\mu \mathrm{C} / \mathrm{m}^{3}\right)\end{array}$ & $\begin{array}{l}\text { EFFECTIVE DOSE } \\
\text { EQUIVALENT } \\
\text { (mrem) }\end{array}$ & $\begin{array}{c}\text { NET CONCENTRATON } \\
\left(\mu \mathrm{C} / \mathrm{m}^{3}\right)\end{array}$ & $\begin{array}{c}\text { EFFECTIVE } \\
\text { DOSE } \\
\text { EQUIVALENT } \\
\text { (mrem) }\end{array}$ & $\begin{array}{c}\text { EFFECTIVE } \\
\text { DOSE } \\
\text { EQUNALENT } \\
\text { (mrem) } \\
\end{array}$ \\
\hline Totall & $5.35 \mathrm{E}-11$ & $0.0040 \pm N / A$ & $-3.72 \mathrm{E}-$ & $\begin{array}{l}0 \pm N / A \\
\end{array}$ & $1.80 \mathrm{E}-10 \pm \mathrm{N} / \mathrm{A}$ & $0.0135 \pm N / A$ & 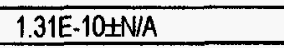 & $0.0099 \pm N / A$ & $0.0272 \pm \mathrm{N} / \mathrm{A}$ \\
\hline $\mathrm{Ra}-226$ & $-6.42 E-13 \pm 1.45 E-11$ & $0 \pm 0.0001$ & $2.52 \mathrm{E}-1$ & $0 \pm 0.0001$ & $1.03 \mathrm{E}-11 \pm 1.74 \mathrm{E}-11$ & $0.0001 \pm 0.0001$ & $1.30 \mathrm{E}-11 \pm 1.55 \mathrm{E}-11$ & $0.0001 \pm 0.0001$ & $0.0002+0.0002$ \\
\hline $\mathrm{Ra}-228$ & $-1.35 \mathrm{E}-11 \pm 8.8$ & $0 \pm 0.0003$ & $58 E-11$ & $0 \pm 0.0003$ & $-2.24 \mathrm{E}-11 \pm 7.33 \mathrm{E}-11$ & $0 \pm 0.0002$ & $\sim$ & - & $0 \pm 0.0004$ \\
\hline Th-228 & $7.23 \mathrm{E}-14 \pm 6.56 \mathrm{E}-12$ & $0 \pm 0.0013$ & $=1.29 \mathrm{E}-11$ & $0 \pm 0.0026$ & $1.03 E-10 \pm 1.66 E-10$ & $0.0210 \pm 0.0339$ & $-1.70 E-11 \pm 8.78 E-11$ & $0 \pm 0.0179$ & $0.0210 \pm 0.0384$ \\
\hline Th-230 & $1.54 \mathrm{E}-12$ & $0.0003 \pm 0.0012$ & $-1.07 \mathrm{E}$ & $0 \pm 0.0009$ & $55 \mathrm{E}-10$ & $0.0124 \pm 0.0302$ & $-5.27 \mathrm{E}-12+9.13 \mathrm{E}-11$ & $0 \pm 0.0178$ & $0.0127 \pm 0.0351$ \\
\hline Th-232 & $5.44 \mathrm{E}-13+2.12 \mathrm{E}-12$ & $0.0005 \pm 0.0021$ & $4.16 E-12$ & $0 \pm 0.0041$ & $2.33 E-11 \pm 1.11 E-10$ & $0.0229+0.1095$ & $-4.49 \mathrm{E}-12+8.81 \mathrm{E}-11$ & $0 \pm 0.0867$ & $0.0234 \pm 0.1397$ \\
\hline & \multirow{2}{*}{\multicolumn{2}{|c|}{$0.0048+0.0028$}} & \multirow{2}{*}{\multicolumn{2}{|c|}{$0 \pm 0.0049$}} & \multirow{2}{*}{\multicolumn{2}{|c|}{$0.0699+0.1185$}} & \multirow{2}{*}{\multicolumn{2}{|c|}{$\begin{array}{l}0.0098 \pm 0.0903 \\
\text { ARTER }\end{array}$}} & $0.0845 \pm 0.1491$ \\
\hline AP- 4008 & & & & & & & & & ANNUAL \\
\hline RADIONUCLIDE & $\begin{array}{c}\text { NET } \\
\text { CONCENTRATON } \\
\left(\mu \mathrm{Ci} / \mathrm{m}^{3}\right)\end{array}$ & $\begin{array}{l}\text { EFFECTIVE } \\
\text { DOSE } \\
\text { EQUIVALENT } \\
\text { (mrem) }\end{array}$ & $\begin{array}{c}\text { NET CONCENTRATON } \\
\left(\mu \mathrm{C} / \mathrm{m}^{2}\right)\end{array}$ & $\begin{array}{l}\text { EFFECTIVE } \\
\text { DOSE } \\
\text { EQUNALENT } \\
\text { (mrem) }\end{array}$ & $\begin{array}{c}\text { NET } \\
\text { CONCENTRATON } \\
\left(\mu \mathrm{C} / \mathrm{m}^{3}\right)\end{array}$ & $\begin{array}{l}\text { EFFECTIVE DOSE } \\
\text { EQUIVALENT } \\
\text { (mrem) }\end{array}$ & $\begin{array}{c}\text { NET CONCENTRATON } \\
\left(\mu \mathrm{C} / \mathrm{m}^{\prime}\right)\end{array}$ & $\begin{array}{l}\text { EFFECTIVE } \\
\text { DOSE } \\
\text { EQUNALENT } \\
\text { (mrem) }\end{array}$ & $\begin{array}{l}\text { EFFECTIVE } \\
\text { DOSE } \\
\text { EQUIVALENT } \\
\text { (mrem) }\end{array}$ \\
\hline Totalu & $2.87 \mathrm{E}-11 \pm \mathrm{N} / \mathrm{A}$ & $0.0017 \pm N / A$ & $91 \mathrm{E}-$ & \begin{tabular}{|l}
$0.0018 \pm N / A$ \\
\end{tabular} & 39E-11 & $0.0020 \pm N / A$ & $2.19 E-11 \pm N / A$ & $0.0013 \pm \mathrm{N} / \mathrm{A}$ & $0.0068 \pm N / A$ \\
\hline $\mathrm{Ra}-226$ & $2.44 E-12+1.45 E-11$ & $0 \pm 0.0001$ & $35 \mathrm{E}-11$ & \begin{tabular}{|l|}
$0 \pm 0.0001$ \\
\end{tabular} & $2.90 E-12 \pm 1.42 E-11$ & $0 \pm 0.0001$ & $2.45 E-12+1.00 E$ & $0 \pm 0.0000$ & $0 \pm 0.0002$ \\
\hline $\mathrm{Ra}-228$ & $1.04 \mathrm{E}-11 \pm 8.55 \mathrm{E}-11$ & $0 \pm 0.0002$ & $991 E-11$ & $0 \pm 0.0002$ & $-2.02 E-11 \pm 6.75 E-11$ & $0 \pm 0.0002$ & $\sim$ & $=$ & $0 \pm 0.0003$ \\
\hline Th-228 & $1.76 \mathrm{E}-12+8.18 \mathrm{E}-12$ & $0.0003 \pm 0.0013$ & $1.79 \mathrm{E}-11 \pm 7.27 \mathrm{E}-11$ & $0.0029 \pm 0.0119$ & $9.86 \mathrm{E}-11 \pm 1.69 \mathrm{E}-10$ & $0.0162 \pm 0.0277$ & $-7.20 \mathrm{E}-$ & $0 \pm 0.0114$ & $0.0194 \pm 0.0322$ \\
\hline Th-230 & $1.74 E-12+6.62 E-12$ & $0.0003 \pm 0.0010$ & $3.19 \mathrm{E}-11$ & $0.0031 \pm$ & $-1.61 \mathrm{E}-11 \pm 1.59 \mathrm{E}-10$ & $0 \pm 0.0248$ & $-4.00 \mathrm{E}-12+7.27 \mathrm{E}-11$ & $0 \pm 0.0114$ & $0.0034 \pm 0.0278$ \\
\hline Th-232 & $3.59 \mathrm{E}-13 \pm 3.00 \mathrm{E}-12$ & $0.0003 \pm 0.0024$ & $2.06 \mathrm{E}-11 \pm 2.73 \mathrm{E}-11$ & $0.0162 \pm 0.0215$ & $-3.23 \mathrm{E}-11 \pm 9.92 \mathrm{E}-11$ & $0 \pm 0.0780$ & $-3.39 \mathrm{E}-12+7.05 \mathrm{E}-11$ & $0 \pm 0.0555$ & $0.0165 \pm 0.0981$ \\
\hline & & 0029 & & $0.0240 \pm 0.0251$ & & 0 & & $0.0013 \pm 0.0578$ & $0.046 \pm 0.1070$ \\
\hline
\end{tabular}


Table 6-4 NESHAPs Isotopic Air Monitoring Results with Effective Dose Equivalent Contributions, 1997 (Continued)

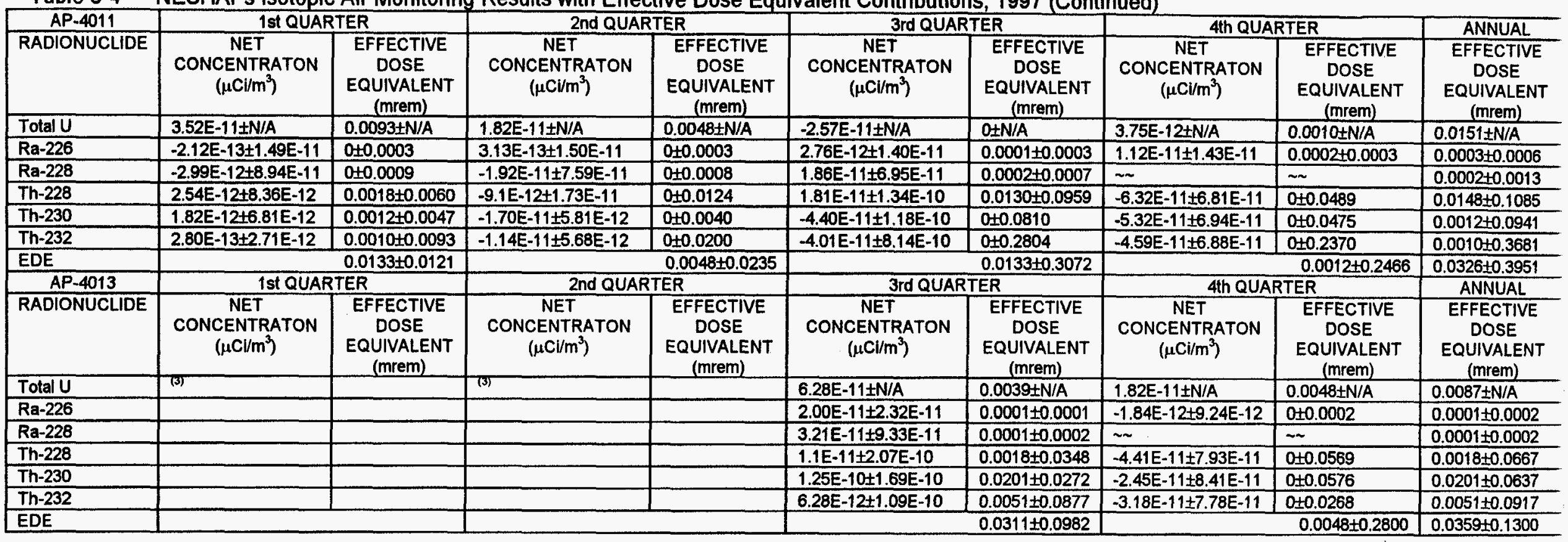


Table 6-4 NESHAPs Isotopic Air Monitoring Results with Effective Dose Equivalent Contributions, 1997 (Continued)

\begin{tabular}{|c|c|c|c|c|c|}
\hline AP-4012 & 1st QUARTER & 2nd QUARTER & 3rd QUARTER & 4th QUARTER & ANNUAL \\
\hline RADIONUCLIDE & CONCENTRATION $\left(\mu \mathrm{Ci} / \mathrm{m}^{3}\right)$ & CONCENTRATION $\left(\mu \mathrm{Cl} / \mathrm{m}^{3}\right)$ & CONCENTRATION $\left(\mu \mathrm{Ci} / \mathrm{m}^{3}\right)$ & CONCENTRATION $\left(\mu \mathrm{Cl} / \mathrm{m}^{3}\right)$ & $\begin{array}{l}\text { EFFECTIVE DOSE } \\
\text { EQUIVALENT (mrem) }\end{array}$ \\
\hline Total U & $9.68 E-11 \pm N / A$ & $3.72 E-11 \pm N / A$ & $2.12 \mathrm{E}-10 \pm \mathrm{N} / \mathrm{A}$ & $1.58 \mathrm{E}-10 \pm \mathrm{N} / \mathrm{A}$ & - \\
\hline Ra-226 & 1.32E-11士1.05E-11 & $2.52 \mathrm{E}-11 \pm 1.07 \mathrm{E}-11$ & $5.89 \mathrm{E}-12+9.87 \mathrm{E}-12$ & $8.44 \mathrm{E}-12+6.68 \mathrm{E}-12$ & - \\
\hline Ra-228 & $1.91 \mathrm{E}-11 \pm 5.71 \mathrm{E}-11$ & $3.82 E-11 \pm 5.95 E-11$ & $6.03 \mathrm{E}-11 \pm 5.01 \mathrm{E}-11$ & $\sim$ & - \\
\hline Th-228 & $1.12 \mathrm{E}-13 \pm 4.92 \mathrm{E}-12$ & $6.56 \mathrm{E}-11 \pm 1.11 \mathrm{E}-11$ & $4.91 \mathrm{E}-11 \pm 1.24 \mathrm{E}-10$ & $1.22 \mathrm{E}-10 \pm 6.21 \mathrm{E}-11$ & - \\
\hline Th-230 & $3.18 \mathrm{E}-12 \pm 3.97 \mathrm{E}-12$ & $1.09 \mathrm{E}-11 \pm 3.41 \mathrm{E}-12$ & $1.87 \mathrm{E}-10 \pm 1.05 \mathrm{E}-10$ & $1.22 \mathrm{E}-10 \pm 6.28 \mathrm{E}-11$ & - \\
\hline Th-232 & $1.15 \mathrm{E}-13 \pm 1.20 \mathrm{E}-12$ & $5.87 \mathrm{E}-11 \pm 3.29 \mathrm{E}-12$ & $1.13 \mathrm{E}-10 \pm 7.22 \mathrm{E}-11$ & $1.19 \mathrm{E}-10 \pm 6.12 \mathrm{E}-11$ & - \\
\hline
\end{tabular}

\footnotetext{
(1) Indicates AP-4006 Assessment 1 in Table 3-1

Indicates AP-4006 Assessment 2 in Table 3-1.

New station added beginning with third quarter.

N/A Now station adde

- Background annual dose not calculated.

$\sim \quad$ Indicates rejected erroneous data.

CEDE Committed Effective Dose Equivalent

Multiply by 0.01 to convert mrem to $\mathrm{mSv}$.

Multiply by 37,000 to convert $\mu \mathrm{Ci} / \mathrm{m}^{3}$ to $\mathrm{Bq} / \mathrm{m}^{3}$.
} 
background concentrations of Ra-228 were applied in dose assessment for this quarter. According to the exposure scenarios (Table 6-3), the maximum committed effective dose equivalent (CEDE) calculated was $0.18 \pm 0.41 \mathrm{mrem}(0.0018 \mathrm{mSv})$ for an individual residing 8,760 hours/year in the Francis Howell High School. The doses calculated for each critical receptor location for the entire year are comparable to those calculated for the last few years and are well below the NESHAPs limit of $10 \mathrm{mrem}(0.10 \mathrm{mSv})$ effective dose equivalent per year from emissions of radionuclides to the ambient air.

One-tailed Student's t-tests were performed at the $95 \%$ confidence level for each station. The measurements for all the radioisotopes listed in Table 6-4 indicated that there were no annual concentrations statistically above background levels at any of the critical receptors.

\subsection{Additional Information}

No unplanned releases to the atmosphere occurred in 1997.

Releases from the WSSRAP are primarily due to diffuse sources. The dose equivalent estimates listed in Table 6-3 are based on critical receptor monitoring, and therefore estimate the dose due to both point source and diffuse source emissions.

Data quality review of precision and accuracy for the NESHAPs high volume samples established in the Plan for Monitoring Radionuclides Other Than Radon at Weldon Spring Site Critical Receptors (Ref. 21) indicated that the data quality objectives (DQOs) for precision were met, however; the DQOs for accuracy were not met for the first, second, and fourth quarters of 1997. Accuracy tests indicated failure of the U-238 and Th-230 spiked samples to meet the known value objective of $\pm 50 \%$ for $85 \%$ of the samples.

In accordance with requirements contained in the Plan for Monitoring Radionuclide Emissions Other Than Radon (Ref. 21), the corrective action reports were developed when results showed that the data quality objectives were not met for the specific quarter. These reports provide information obtained from the investigations and give the practical suggestions in further analyses methodology and procedures. Based on this provided information, it is believed that the specific air sample matrix and its chem-radiological characteristics could be the cause of difficulties experienced during the sample digesting process, therefore resulting in the low spike recovery. Also, the critical receptor location samples have concentrations comparable to background levels, which can contribute to difficulties with sample analysis.

In order to achieve the quality control objectives for NESHAPs analyses, WSSRAP continues investigating and evaluating options that would help to improve the sample quality 
control index. Actions have been taken to establish an efficient analyzing procedure and possible alternative methodologies have been considered.

\subsection{Supplemental Information}

Although not required by 40 CFR 61 , this supplemental information is provided to assist the DOE in guidance development and in future interactions with the EPA. Information includes the following: collective population dose equivalent and airborne releases of radionuclides, status of compliance with 40 CFR 61 Subparts $Q$ and T, details of non-storage radon emissions, a discussion of radionuclide emission points, and the status of the site quality assurance program for radionuclide emissions measurements.

\subsubsection{Collective Population Dose and Airborne Release Estimates}

Dose Estimates. Statistical tests performed at the $95 \%$ confidence level for each NESHAPS monitoring result indicated no above-background concentrations. However, the total 1997 collective population dose equivalent was performed for locations that were considered exposure points. Exposure points are defined as locations where there is a potential for members of the public to be exposed to above-background concentrations of airborne radioactive particulate, radon gas concentrations, external gamma radiation, and radionuclides in food or water. All four pathways are addressed for the collective population dose estimate.

The statistical test at the $95 \%$ confidence level for all of the air particulate, radon gas, and gamma exposure measurements at the critical receptor monitoring locations indicated there were no elevated levels of exposure, except at a gamma monitoring station TD-2004, and at low volume air particulate monitoring station AP-2005. The NESHAPs monitoring results at AP-2005, however, indicated no above background concentrations of radionuclides.

The environmental thermoluminescent dosimeter (TLD) station TD-2004, which monitors environmental gamma exposure, is located at the Weldon Spring Chemical Plant perimeter adjacent to the Missouri Highway Maintenance facility, just northeast of the chemical plant perimeter. The low volume air monitoring station AP-2005 is at the WSSRAP administration building and is used to determine the long-lived gross alpha concentration. The above background results obtained from the statistical test for both stations indicated a need to evaluate the potential general population exposures.

Another potential general population exposure is from the consumption of water, sediment, and fish from the August A. Busch Memorial Conservation Area. Three lakes at the conservation area receive runoff from the Weldon Spring site and are used for fishing and boating. Scenarios were developed and dose assessments were performed for nine employees of the MHTD facility, 300 employees at the WSSRAP, and 160,000 users of the Busch Memorial 
Conservation Area, in 1997. The estimated total collective population dose equivalent was 0.13 person-rem (0.0013 person-Sv) in 1997. Calculations are presented in Appendix B, Section D.

Airborne Release Estimates. During 1997, statistical analysis of annual average high volume monitoring results used for the NESHAPs report indicated no locations where airborne radionuclide concentrations were greater than background. However, four low volume monitoring stations along the chemical plant perimeter indicated annual average concentrations that were statistically greater than the average background concentration. These stations were AP-2002, 3003, 3004, and 2005. The net annual average gross alpha concentrations at these stations were incorporated into a series of box models to estimate the total radioactive airborne particulate release from the site for 1997. The box model approach provides conservative results and is used in place of Gaussian plume dispersion modeling, which is generally inappropriate for estimating ambient pollutant concentrations at receptors close to a source such as the perimeter monitors at the WSSRAP. Calculations are presented in Appendix B, Section E to estimate the radionuclide-specific activity releases during 1997.

\subsubsection{Subparts $Q$ and T of 40 CFR 61}

The regulations contained in Subpart $Q$ pertain to $\mathrm{Rn}-222$ emissions from radiumcontaining storage or disposal facilities. Removal of the bulk waste from the quarry and placement in the TSA was completed in 1995. Radon flux measurements at the TSA were initiated in the second quarter of 1996 and were completed in the first quarter of 1997. The average $\mathrm{Rn}-222$ flux rate measurements were well below the limitation of $20 \mathrm{pCi} / \mathrm{m}^{2} / \mathrm{s}$ listed in 40 CFR 61, Subpart Q. Additional information about these measurements is contained in Section 11.3 of this report.

The regulations contained in 40 CFR 61 Subpart $T$ apply only to sites that are "...listed in, or designated by, the Secretary of Energy under Title I of the Uranium Mill Tailings Control Act of 1978 or regulated under Title II of the Uranium Mill Tailings Control Act of 1978." Subpart $\mathrm{T}$ does not apply to the Weldon Spring site since it does not fall into the applicable categories.

\subsubsection{Radon Emissions from WSSRAP Non-Storage Sources}

\subsubsection{Rn-220 Emissions}

The Weldon Spring Quarry was used for disposal of a variety of radiologically and chemically contaminated wastes from the early 1940s to 1969. In December 1995, the transfer of quarry bulk waste to the TSA was completed. Included in the radiologically contaminated waste disposal inventory is at least $612 \mathrm{~m}^{3}$ (800 cu yd) of Th-232 residues received from Cincinnati, Ohio in 1959 and 1966, and an unknown quantity of Th-232 contaminated residues, rubble, and 
equipment received since the shutdown of the chemical plant in 1966. Radiological characterizations of the quarry wastes were performed in 1984 and 1985 . Ra-228 concentrations detected in the quarry wastes during characterization activities ranged from $1.0 \mathrm{pCi} / \mathrm{g}$ $(0.037 \mathrm{~Bq} / \mathrm{g})$ to $2,200 \mathrm{pCi} / \mathrm{g}(81.4 \mathrm{~Bq} / \mathrm{g})$. Additional information about Th-232 wastes is contained in the Remedial Investigation for Quarry Bulk Wastes (Ref. 2).

Radon-220 monitoring was performed at the quarry during 1997. The statistical analysis results at the $95 \%$ confidence level indicated that the annual $R n-220$ concentration at station RD-1002 was greater than background levels. Although no remedial actions occurred at the quarry during 1997 , the slightly elevated $\mathrm{Rn}-220$ result indicated that residual thorium contamination is still present at the quarry upper rim area. The above background alpha-track radon detector $\mathrm{Rn}-220$ result was incorporated into a box model to estimate the airborne $\mathrm{Rn}-220$ emissions from the quarry. The box model approach provides conservative results and is used in place of Gaussian dispersion modeling, which is generally inappropriate for estimating contaminant concentrations at close-in receptors. The estimated off-site $\mathrm{Rn}-220$ release during 1997 was $0.43 \mathrm{Ci}(1.6 \mathrm{E} 10 \mathrm{~Bq})$. This corresponds to a committed effective dose equivalent to the hypothetical maximally exposed individual of $1.0 \mathrm{E}-3 \mathrm{mrem}(1.0 \mathrm{E}-5 \mathrm{mSv})$. Calculations are presented in Appendix B, Parts B and F.

Other potential $\mathrm{Rn}-220$ sources are the TSA, which is used for the storage of the quarry bulk wastes, and the four raffinate pits used for the storage of wastes from past uranium refinery operations. Radiological characterization of the raffinate pits waste indicated Ra-228 concentrations ranging from $4 \mathrm{pCi} / \mathrm{g}(0.148 \mathrm{~Bq} / \mathrm{g})$ to $1,400 \mathrm{pCi} / \mathrm{g}(51.8 \mathrm{~Bq} / \mathrm{g})$. Remediation activities including the dredging/dewatering at the pits, sludge consolidation in Raffinate Pit 4, and excavation of sludge from the Raffinate Pits 2 and 3, all resulted in increased Rn-220 emissions to the atmosphere.

The chemical plant perimeter is monitored for radon gas at 10 locations using alpha track radon monitors. Statistical analysis of the results at the $95 \%$ confidence level indicated that three monitoring locations, RD-3001. RD-3002, and RD-3003, had annual Rn-220 concentrations greater than background levels. To estimate the airborne Rn-220 emissions from the chemical plant during 1997 , the above background alpha-track radon detector $R n-220$ results were incorporated into a series of box models. The estimated off-site $\mathrm{Rn}-220$ release from the chemical plant was $41.3 \mathrm{Ci}(1.53 \mathrm{E} 12 \mathrm{~Bq})$. Calculations and assumptions are provided in Appendix B, Part F. 


\subsubsection{Rn-222 Emissions}

As stated in Section 6.6.3.1, the quarry was used for disposal of a variety of radiologically and chemically contaminated wastes from the early 1940 s to 1969 . The transfer of quarry bulk waste to the TSA at the chemical plant was completed in 1995. Included in the waste disposal inventory is demolition rubble from the Destrehan Street feed materials plant in St. Louis, Missouri. The waste contained less than $1 \mathrm{Ci}(3.7 \mathrm{E} 10 \mathrm{~Bq})$ of $\mathrm{Ra}-226$. Also, several buildings at the chemical plant were decontaminated and approximately $4,200 \mathrm{~m}^{3}(5,500 \mathrm{cu}$ yd) of waste materials were dumped in the quarry. The wastes contained uranium and its progeny. Radiological characterizations of the above material were performed in 1984 and 1985 . Ra-226 concentrations detected in the waste during characterization ranged from $0.2 \mathrm{pCi} / \mathrm{g}(0.007 \mathrm{~Bq} / \mathrm{g})$ to $2,780 \mathrm{pCi} / \mathrm{g}(103 \mathrm{~Bq} / \mathrm{g})$. Additional information about $\mathrm{Ra}-226$ waste removed from the quarry is contained in the Remedial Investigation for Quarry Bulk Wastes (Ref. 2).

The other primary non-storage source of $\mathrm{Rn}-222$ during 1997 was the four raffinate pits that were used for the storage of waste resulting from past uranium refinery operations. Radiological characterization of the raffinate pits waste indicated $\mathrm{Ra}-226$ concentrations ranging from $1 \mathrm{pCi} / \mathrm{g}(0.037 \mathrm{~Bq} / \mathrm{g})$ to $1,700 \mathrm{pCi} / \mathrm{g}(63 \mathrm{~Bq} / \mathrm{g})$. As stated in Section 6.6.3.1, the raffinate pit remedial activities have exposed radon-bearing waste to the atmosphere.

The chemical plant perimeter is monitored for radon gas at 10 locations. Statistical analysis of the monitoring results during 1997 indicated that there was no reason to suspect at the $95 \%$ confidence level that radon concentrations were greater than background levels.

\subsubsection{Effluent Monitoring Requirements}

The site water treatment plant and the quarry water treatment plant were in operation during 1997 and were potential point sources of radioactive airborne particulates. The WSSRAP has developed a plan to continuously monitor air concentrations of radioactive particulates resulting from remedial activities, at designated critical receptor locations in accordance with 40 CFR 61.93, Paragraph (b)(5). This approach is contained in the Plan for Monitoring Radionuclide Emissions Other Than Radon at Weldon Spring Site Critical Receptors (Ref. 21), which has been approved by EPA Region VII. The report includes a discussion of the WSSRAP quality assurance program for measurement of radionuclide emissions from the Weldon Spring site. This program conforms to the requirements of 40 CFR 61, Appendix B, Method 114, and ensures that emission measurements are representative and are of known precision and accuracy. Data quality objectives outlined by the quality assurance program are also discussed in the plan. 


\section{SURFACE WATER PROTECTION}

\subsection{Highlights of the Surface Water Program}

The following are highlights of the 1997 surface water program. These items, and others, are discussed in detail in this chapter.

- The mass of uranium migrating off site in storm water and treated effluent, $22.2 \mathrm{~kg} / \mathrm{yr}$ (48.9 lbs/yr), was reduced by $42 \%$ over the 1996 mass of $38.3 \mathrm{~kg} / \mathrm{yr}(84.4 \mathrm{lbs} / \mathrm{yr}$ ) (see Figures 11-1, 11-2, and 11-3).

- Eleven batches of water were released from the site and quarry water treatment plants during 1997 in compliance with all NPDES permit conditions.

- The overall results of the WET tests indicate that the site and quarry water treatment plant effluent was not toxic to test organisms during 1997.

- Total uranium levels in the Femme Osage Slough were within historical ranges.

\subsection{Program Overview}

The environmental monitoring and protection program for surface waters at the Weldon Spring Site Remedial Action Project (WSSRAP) is prescribed in the Environmental Monitoring Plan (Ref. 42) and includes monitoring discharge points permitted under the National Pollutant Discharge Elimination System (NPDES) program and streams, ponds, and lakes under the surface water monitoring program.

The effluent, or NPDES, monitoring program at the Weldon Spring site establishes sampling requirements for discharge points (outfalls) at both the chemical plant and the quarry. The goals of this program are to maintain compliance with the NPDES permit requirements and to protect the health of downstream water users and the environment by characterizing water released from the site. In accordance with the WSSRAP policy that all surface water be closely monitored and treated, as necessary, to meet Federal and State requirements, the Project Management Contractor (PMC) uses the water sample data to develop strategies to minimize the discharge of waterborne contaminants from the site.

In addition, the surface water monitoring program monitors off-site water bodies for uranium contamination and temporal changes in uranium levels. The data generated from this monitoring are used in conjunction with NPDES monitoring to measure the success of the project's goal to clean up the site with no long term increase in contaminant discharge or degradation of the off-site water bodies. 


\subsection{Applicable Standards}

The WSSRAP is subject to, and complies with, Executive Order 12088, which requires all Federal facilities to comply with applicable pollution control standards. Effluent discharges from the site for 1997 were authorized by four NPDES permits issued by the Missouri Department of Natural Resources (MDNR). The MDNR requires specific parameters to be monitored at outfalls listed in each permit. Each parameter is assigned either effluent limits or a "monitoring only" status, which means the concentrations are reported but not limited by the permit. Sampling frequencies and reporting requirements for the two major permits, MO-0107701 and MO-0108987, are summarized in Tables 7-1 and 7-2. These permits were reissued on March 4, 1994, and June 10, 1994, respectively. Permit MO-0107701 was revised on January 31. 1997. It was again revised on April 11, 1997, to correct a minor administration error.

The Borrow Area and Borrow Area haul road land disturbance storm water permit, MO-R100B69, issued September 1, 1994, has no specified monitoring or reporting requirements. A program was developed in the Environmental Monitoring Plan (Ref. 42) for monitoring settleable solids and, under certain circumstances, oil and grease. The results of this monitoring were used to measure the effectiveness of erosion control and to improve controls, if required. An application to renew the permit was submitted to the MDNR on February 10, 1997, and was pending as of December 31, 1997.

Effluent discharges are also regulated by Department of Energy (DOE) Order 5400.5, which calls for a best available technology evaluation if the annual average uranium concentration at an outfall exceeds the derived concentration guideline (DCG) for natural uranium $(600 \mathrm{pCi} / 1$ [22.2 Bq/l]). Measures are also taken to keep uranium concentrations as low as reasonably achievable (ALARA).

Permit MO-G670203 was issued on December 5, 1997, for the discharge of hydrostatic test water from the chemical plant site. Sampling frequency and reporting requirements and results are discussed in Section 7.6.1.2.4.

The primary criteria used to develop the surface water monitoring program were the Missouri Water Quality Standards for drinking water supplies established under the Missouri Clean Water Commission Regulation 10 CSR 20-7.031 and the U.S. Environmental Protection Agency primary and secondary maximum contaminant level concentrations for drinking water. A table of applicable water standards that includes contaminants routinely monitored in the surface water program can be found in Section 8. 
Table 7-1 Weldon Spring Chemical Plant Storm and Sanitary Water (NPDES Permit MO-0107701) Monitoring Requirements

\begin{tabular}{|c|c|c|}
\hline \multirow[b]{2}{*}{ PARAMETER } & \multicolumn{2}{|c|}{ LOCATION } \\
\hline & $\begin{array}{c}\text { NP-0002, NP-0003 }{ }^{\left({ }^{()}\right)}, \text {NP-0005, } \\
\text { NP-0010 }\end{array}$ & NP-0006 \\
\hline Sampling Frequency & once/month & once/quarter \\
\hline Flow & GPD (monitor only) & GPD (monitor only) ${ }^{(\mathrm{a})}$ \\
\hline Settleable Solids & $1.0 \mathrm{ml} / \mathrm{l} / \mathrm{hr}$ & - \\
\hline TSS & $\mathrm{mg} / \mathrm{l}$ (monitor only) & $30 / 45 \mathrm{mg} / \mathrm{l}^{(\otimes)}$ \\
\hline Nitrate and Nitrite as $\mathrm{N}$ & mg/l (monitor only) & - \\
\hline Uranium, total & $\mathrm{mg} / \mathrm{l}$ (monitor only) & - \\
\hline Gross alpha & $\mathrm{pCi} / /$ (monitor oniy) & - \\
\hline $\mathrm{pH}$ & 6 - 9 standard units & 6 - 9 standard units \\
\hline Fecal coliform & - & $\begin{array}{c}400 / 1000 \text { colonies } / \\
100 \mathrm{~m}(\mathrm{c})\end{array}$ \\
\hline $\mathrm{BOD}$ & - & $30 / 45 \mathrm{mg} / \mathrm{l}^{(\mathrm{e})}$ \\
\hline
\end{tabular}

NOTE: Refer to Figure 7-1 for NPDES monitoring locations.

* Permit requires reporting in both $\mathrm{mg} / \mathrm{l}$ and $\mathrm{pCil}$ and notification of MDNR if uranium concentration in any sample exceeds $2 \mathrm{mg} / \mathrm{l}$.

(a) Frequency is once/month.

(b) Limit is $50 \mathrm{mg} / \mathrm{l}$ if erosion control is not designed for a oire 10 year, 24-hour storm.

(c) Monthly average/daily maximum.

(d) NPDES permit MO-0107701 includes sampling of creosote constituents, $\mathrm{Cu}$ and $\mathrm{Zn}$ in the chipped wood storage area pond prior to discharge to Outfall NP-0003. See Table 7-2 for limits.

(e) Monthly average/weekly average.

- Not Applicable. 
Table 7-2 Treated Effluent Parameter Limits and Monitoring Requirements for Quarry Water Treatment Plant (NPDES Permit MO-0108987) and Site Water Treatment Plant (NPDES Permit MO-0107701)*

\begin{tabular}{|c|c|c|c|}
\hline \multirow[b]{2}{*}{ PARAMETER } & LOCATION & \multirow[b]{2}{*}{ PARAMETER } & \multirow{2}{*}{$\begin{array}{l}\text { LOCATION } \\
\text { NP-0007**I } \\
\text { NP-1001 }\end{array}$} \\
\hline & $\begin{array}{l}\text { NP-0007**I } \\
\text { NP-1001 }\end{array}$ & & \\
\hline Gross $\alpha$ & $\mathrm{pCi} / /^{(a)}$ & $\mathrm{Pb}$, total & $0.20 / 0.10 \mathrm{mg} / \mathrm{l}$ \\
\hline Gross $\beta$ & $\mathrm{pCi} / /^{(a)}$ & Mn, total & $0.50 / 0.10 \mathrm{mg} / \mathrm{l}$ \\
\hline Uranium, total & $\mathrm{pCi} / /^{(\mathrm{a})(\mathrm{b})}$ & $\mathrm{Hg}$, total & $0.005 / 0.004 \mathrm{mg} / /$ \\
\hline $\operatorname{Ra}-226^{(\mathrm{c})}$ & $\mathrm{pCi} / /^{(a)}$ & Se, total & $0.05 / 0.02 \mathrm{mg} / \mathrm{l}$ \\
\hline $\operatorname{Ra}-228^{(c)}$ & $\mathrm{pCi} /{ }^{(a)}$ & Cyanide, Amenable & $0.05 / 0.0075 \mathrm{mg} / \mathrm{l}$ \\
\hline Th-230 (c) & $\mathrm{pCi} / /^{(a)}$ & $2,4-D N T$ & $1.1 / 0.22 \mu \mathrm{g} / \mathrm{l}$ \\
\hline$T h-232^{(c)}$ & $\mathrm{pCi} / /^{(a)}$ & Fluoride, total & $12 / 4.0 \mathrm{mg} / \mathrm{l}$ \\
\hline Flow & $G^{\prime} D^{(2)}$ & Nitrate and Nitrite as $\mathrm{N}$ & $100 \mathrm{mg} / \mathrm{l}^{(\mathrm{g})}$ \\
\hline COD & $90(60) \mathrm{mg} / \mathrm{l}^{(\mathrm{e})}$ & Sulfate as $\mathrm{SO}_{4}$ & $1000 / 500 \mathrm{mg} / \mathrm{l}$ \\
\hline TSS & $50(30) \mathrm{mg} / /^{(e)}$ & Chloride & $\mathrm{mg} / \mathrm{I}^{(\mathrm{a})}$ \\
\hline $\mathrm{pH}$ & $6-9$ standard units & Priority Pollutants ${ }^{(1)}$ & $m g f^{(a)(n)(n)}$ \\
\hline As, total & $0.20 / 0.10 \mathrm{mg} / \mathrm{l}$ & Whole Effluent Toxicity & (1) \\
\hline Cr, total & $0.40 / 0.10 \mathrm{mg} / \mathrm{l}$ & $P 0-210^{(d)}$ & $\mathrm{pCi} /\left.\right|^{(\mathrm{a})(\mathrm{h})}$ \\
\hline $\mathrm{Cu}^{(\mathrm{d})(\mathrm{a})}$ & $\mathrm{N} / \mathrm{A} / 1.00 \mathrm{mg} / \mathrm{l}$ & $A c-227^{(0)}$ & $\mathrm{pCi/l^{(a)(n) }}$ \\
\hline Cu-Site & $1.0(0.66) \mathrm{mg} / \mathrm{h}^{(\mathrm{e})(\mathrm{k})}$ & Radon $^{(\mathrm{d})}$ & $\mathrm{pCi} / /^{(\mathrm{a})(\mathrm{n})}$ \\
\hline Zn-Site & $5.0(3.33) \mathrm{mg} / /^{(0)(\mathrm{k})}$ & Creosote-site & $(m)(k)$ \\
\hline
\end{tabular}

NOTE: Refer to Figure 7-2 for NPDES monitoring locations.

* $\quad$ Frequency $=$ once per batch unless otherwise noted

** Site limits in effect January 31,1997. Limits January 1-31 are same as quarry limits. Unless otherwise indicated, limits apply to both site and quarry.

(a) Monitoring only.

(b) Water treatment plants designed for an average concentration of $30 \mathrm{pCi} / \mathrm{l}(1.11 \mathrm{~Bq} / \mathrm{l})$ and never to exceed concentrations of $100 \mathrm{pCi} /(3.7 \mathrm{~Bq} / \mathrm{l})$.

(c) Once/month.

(d) Quarry only.

(e) Daily maximum (monthly average).

(f) Priority pollutants are listed in 40 CFR 122.21 Appendix D, Tables II and III.

(g) Limit applies to chemical plant; monitoring only at quarry. Limit at site was $20 \mathrm{mg} / \mathrm{l}$ for January 1-31, 1997.

(h) Annual monitoring.

(i) Quarterly monitoring.

(j) "No statistical difference between effluent and upstream results at $95 \%$ confidence level."

(k) Once per batch for each batch sampled within a period of 30 days following introduction of CWSA water (which has failed these limits) to the SWTP.

(I) includes: acenaphthylene, acenaphthene, benzo(a)anthracene, dibenzo(a, h)anthracene, benzo(a)pyrene, benzo $(k)$ fluoranthene, chrysene, fluoranthene, fluorene, indeno $(1,2,3-c d)$ pyrene, naphthalene, and phenanthrene.

(m) Daily maximum - $2.5 \times$ Q.L., monthly average - $1.5 \times$ Q.L. Q.L. - quantification level as set by most recent edition of Standard Methods (Q.L. taken as practical quantification limit [PQL]).

(n) Polychlorinated biphenyls (PCBs) have a limit of $1 \mu \mathrm{g} / \mathrm{l}$. 
Surface water, other than NPDES outfalls, is also monitored under the requirements of DOE Order 5400.5, Radiation Protection of the Public and the Environment, which designates DCGs for ingestion of water.

\subsection{Hydrology Description of the Site and Quarry}

Separate surface water monitoring programs have been developed at the chemical plant and quarry due to differences in the topography and hydrologic conditions. Both programs take into account the mechanisms controlling surface water source areas.

\subsubsection{Weldon Spring Chemical Plant and Weldon Spring Raffinate Pits}

The chemical plant area is located on the Missouri-Mississippi River surface drainage divide (Figures 7-1 and 7-2). The topography is gently undulating and generally slopes northward to the Mississippi River and, more steeply, southward to the Missouri River. Streams do not run through the property, but because the site is elevated above surrounding areas, drainageways originate on the property and convey storm water off site. Surface drainage from the western portion of the site, which includes Ash Pond, the material staging area (MSA), the chipped wood storage area (CWSA), and areas adjacent to the temporary storage area (TSA) and the raffinate pits drains to tributaries of Busch Lake 35 and then to Schote Creek, which in turn enters Dardenne Creek, ultimately draining to the Mississippi River (Figure 7-1). Ash Pond no longer accumulates water unless a valve is closed in the discharge structure. If Ash Pond runoff has a uranium concentration greater than $600 \mathrm{pCi} / 1(22.2 \mathrm{~Bq} / 1)$ the valve is closed. If the ponded water is below $600 \mathrm{pCi} / 1$ after the runoff event it may be released, otherwise it is stored in the pond or transferred for treatment. The MSA basin (SW-2015) is a temporary holding pond that collects storm water runoff from the staging area. After monitoring for uranium and meeting the specified release level of less than $600 \mathrm{pCi} / /(22.2 \mathrm{~Bq} / 1)$, this impoundment is periodically pumped into the Ash Pond diversion channel which flows to Sedimentation Basin 4. The CWSA basin is similarly operated by sampling for parameters prescribed in permit MO-0107701. If the parameters are within the limits the water is discharged to the Ash Pond diversion channel, if not, the water is transferred for treatment. All water that discharges to Outfall NP-0003 flows to the sedimentation basin first.

Surface water drainage from the north and east sections of the chemical plant, which includes Frog Pond and the disposal cell, discharges to Dardenne Creek from Schote Creek after first flowing through Busch Lakes 36 and 35 (Figures 7-1 and 7-2). All storm water flow which previously entered Frog Pond has been diverted around Frog Pond except for runoff from the immediate vicinity. Storm water runoff from the cell area will flow to Outfall NP-0002 until waste is placed in the cell. At that time, storm water runoff from the contaminated areas of the cell will be collected in retention basins for transfer to the site water treatment plant area. 


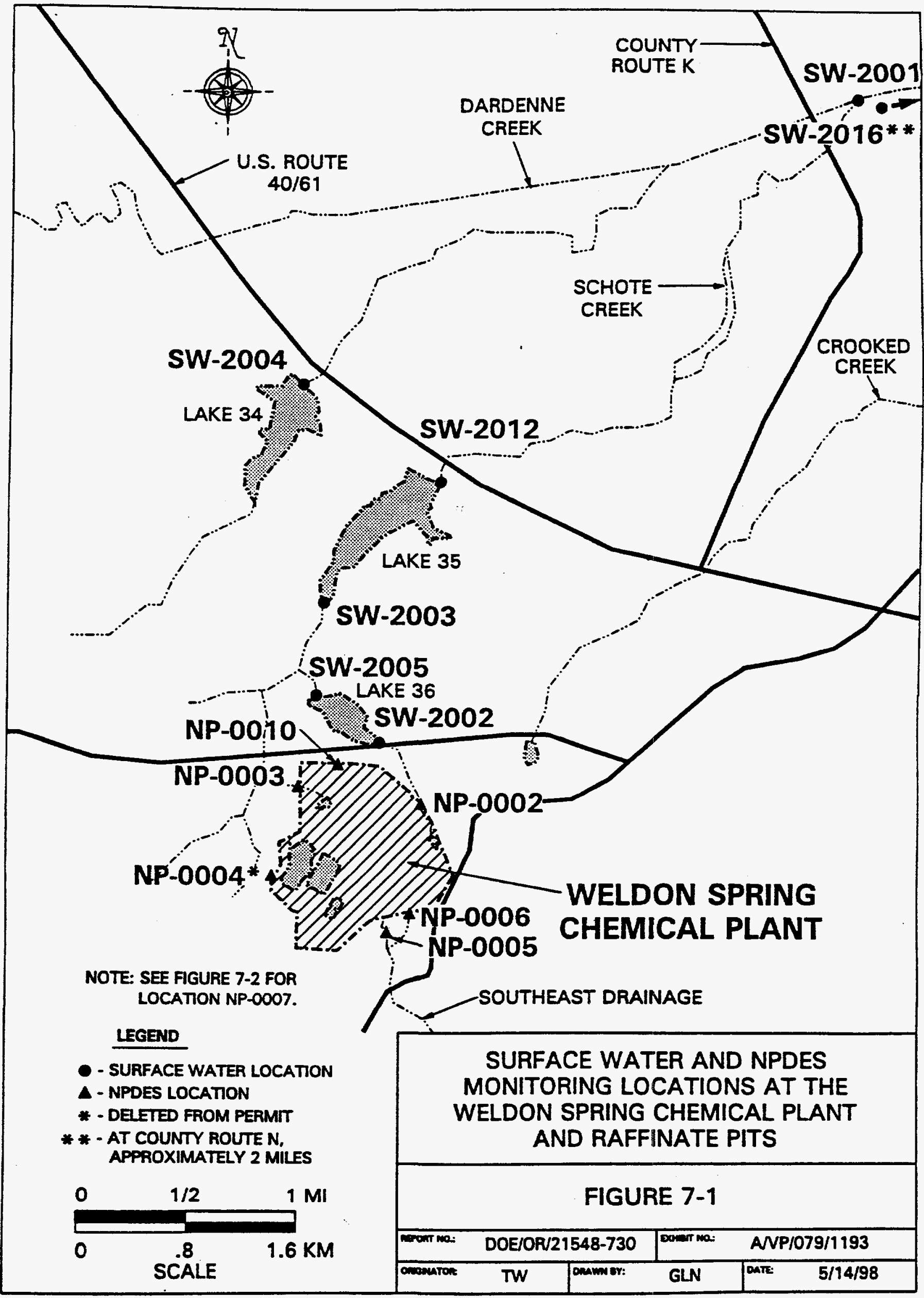




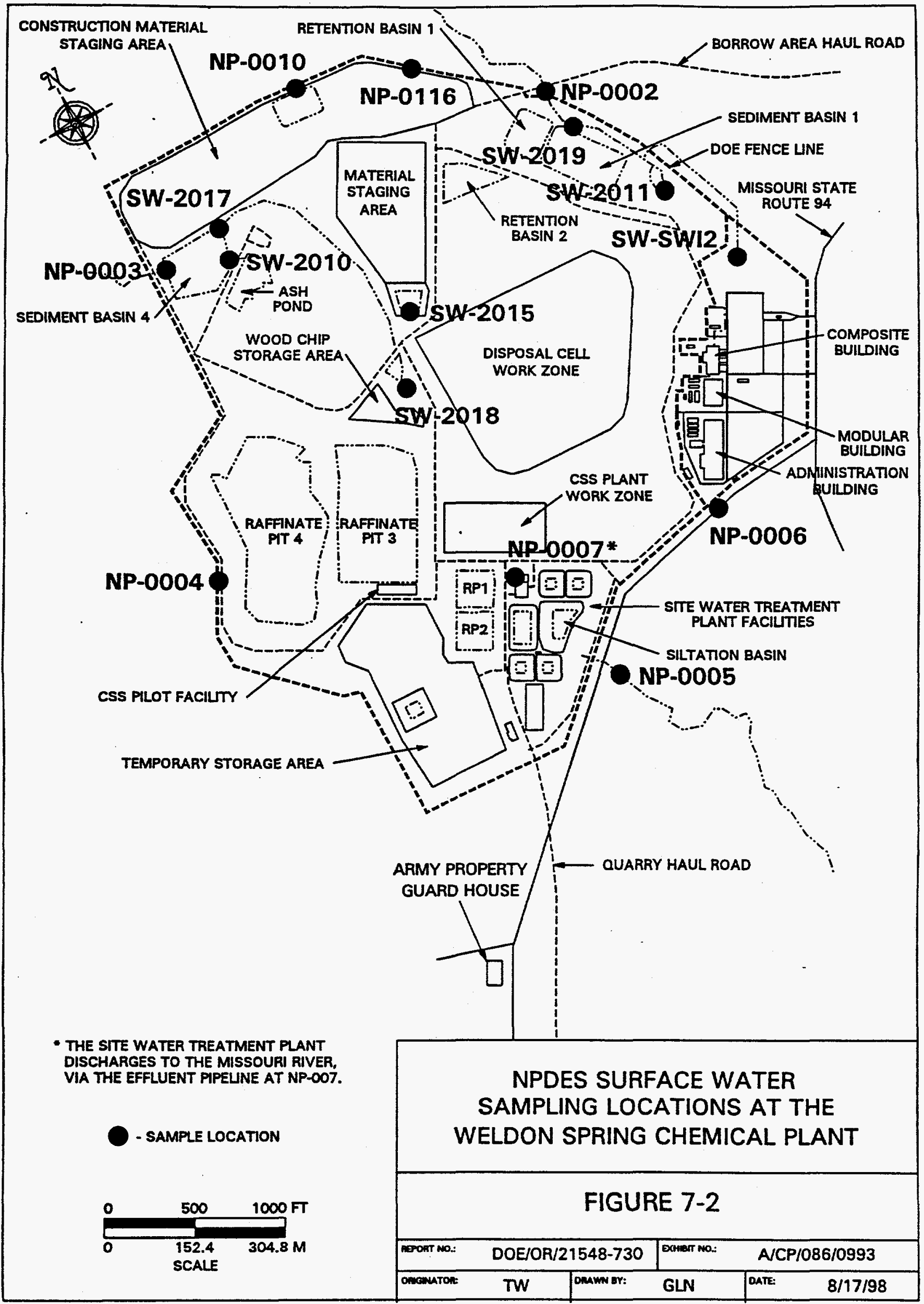


Except for direct precipitation on Frog Pond and parking lot runoff, all water that discharges to Outfall NP-0002 flows to the sedimentation basin first.

Runoff from the southern portion of the chemical plant site (Figures 7-1 and 7-2) which includes the site water treatment plant, Building 434 and parking and equipment areas for the Chemical Stabilization and Solidification (CSS) Facility, flows southeast to the Missouri River via the Southeast Drainage (Valley 5300). All storm water runoff from this area, except for minor flows from the Building 434 area and some roadside ditches, flows through a sedimentation basin just upstream of Outfall NP-0005.

The four raffinate pits, located in the southwestern portion of the chemical plant area do not discharge to the surface and collect only direct precipitation. Water from the raffinate pits has been, and will continue to be, treated at the site water treatment plant before release.

\subsubsection{Weldon Spring Quarry}

Surface water bodies in the quarry area are the Femme Osage Slough, the Little Femme Osage Creek, and the Femme Osage Creek (Figure 7-3). These water bodies do not receive direct runoff from the quarry, but are sampled to monitor potential changes due to the movement of contaminated groundwater from the fractured bedrock of the quarry through the fine-grained alluvial materials.

The Femme Osage Slough is located directly south of the quarry and is known to receive contaminated groundwater from the quarry through subsurface recharge. There is no natural surface flow from the slough; it is essentially land locked. The Little Femme Osage Creek is located west of the quarry and discharges into the Femme Osage Creek approximately $0.5 \mathrm{~km}$ $(0.3 \mathrm{mi})$ southwest of the quarry. The Femme Osage Creek then flows into the Missouri River. Although there has been no evidence of impact from contaminated groundwater on the creeks via stream emergence, they are monitored to detect any changes in the system.

\subsection{Monitoring}

Sections 7.5.1 and 7.5.2 discuss monitoring requirements at NPDES outfalls and surface water locations at the chemical plant site and the quarry.

\subsubsection{National Pollutant Discharge Elimination System Monitoring}

The NPDES permits issued to the site identify the parameters to be monitored. The permit requirements for the two major permits are shown in Tables 7-1 and 7-2 and the requirements for the two minor permits are discussed in the text. Physical, chemical, and radiological parameters were monitored at all storm water outfalls, the quarry water treatment 


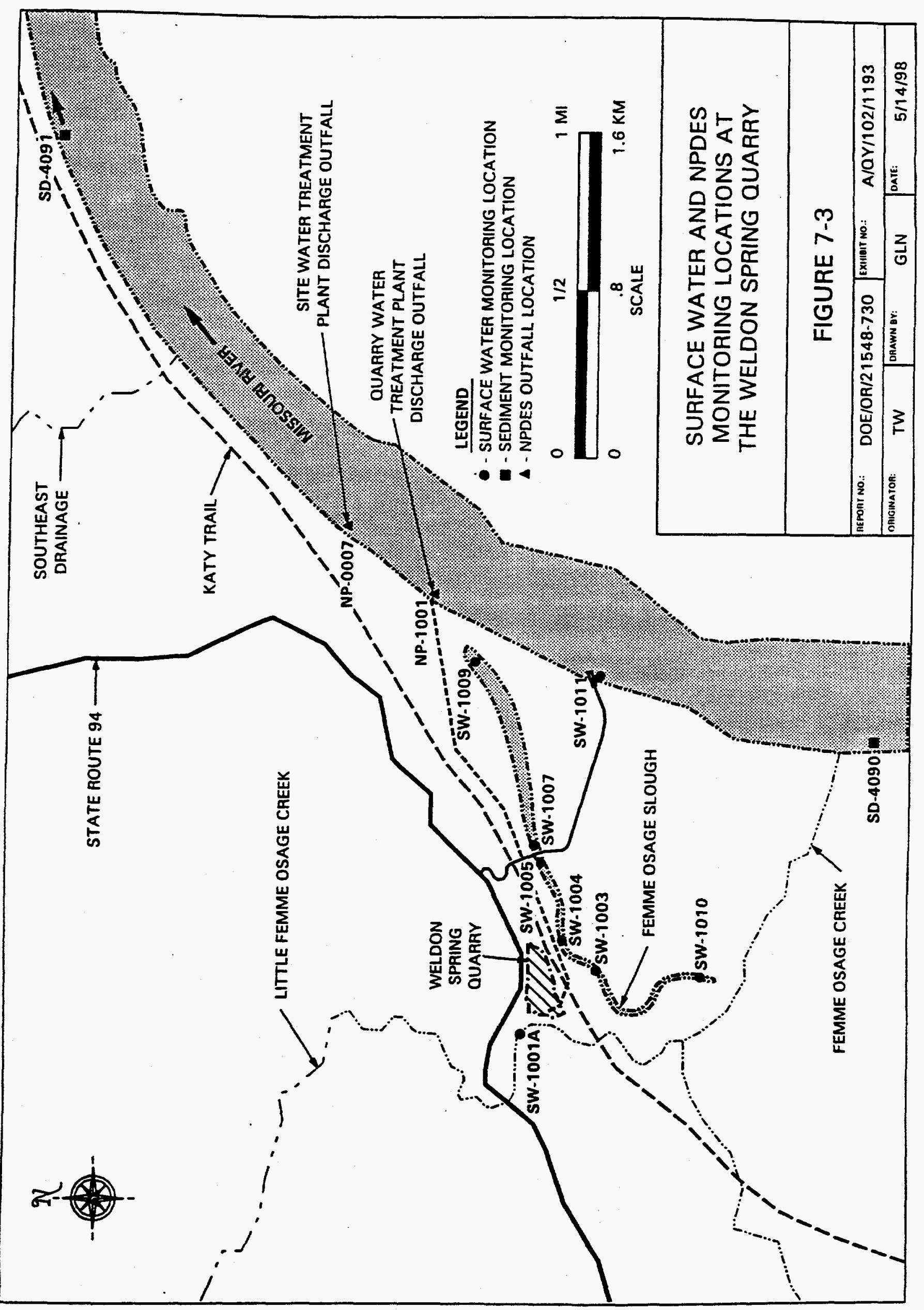


plant and site water treatment plant effluents. The Environmental Monitoring Plan (Ref. 42) also reflects the requirements of the NPDES permits.

In addition to the permitted outfalls, samples were collected upstream of NPDES storm water Outfall NP-0002, from sampling locations SW-2011 (Frog Pond), and SW-2019 (Sedimentation Basin No. 1); and upstream of NPDES storm water Outfall NP-0005; from location SW-2010 (Ash Pond); and SW-2017 (Ash Pond diversion channel). Quarterly samples were also collected from the MSA pond and Ash Pond, when possible, to monitor the effects of materials stored in those areas on contaminant levels in the storm water runoff.

\subsubsection{Surface Water Monitoring}

The following two subsections discuss surface water monitoring requirements at the chemical plant site and the quarry.

\subsubsection{Weldon Spring Chemical Plant and Weldon Spring Raffinate Pits}

Under the surface water monitoring program, Dardenne Creek, and Busch Lakes 34, 35, and 36 were sampled quarterly for total uranium (Ref. 42). Samples were analyzed on the site Kinetic Phosphorescent Analyzer (KPA). This monitoring was conducted to measure the effects of surface water discharges from the site on downstream surface water. The raffinate pits were previously monitored as surface water, but are now monitored under treatment plant operations sampling. The MSA pond, Ash Pond, and Frog Pond were also previously sampled under the surface water program, but are now monitored in conjunction with the NPDES program because they discharge to NPDES permitted outfalls.

\subsubsection{Weldon Spring Quarry}

Six locations within the Femme Osage Slough were monitored to determine the impact of groundwater migration from the quarry. Surface water locations SW-1003, SW-1004, and SW-1005 (Figure 7-3) were monitored bimonthly for total uranium because of past significant contaminant levels in these areas, fluctuations in concentrations due to changes in water levels in the slough and groundwater potentiometric surface, and the potential for these surface water contaminants to impact groundwater south of the slough. The remaining locations (SW-1007, SW-1008, and SW-1009) were sampled quarterly to provide sufficient data to determine any changes in these areas. Locations SW-1003, SW-1004, and SW-1005 were also monitored semiannually for nitroaromatic compounds because these locations are downgradient from the area of greatest nitroaromatic groundwater contamination. Location SW-1001A was sampled once during 1997 for anions and metals. The monitoring location was established along the Little Femme Osage Creek adjacent to and west of the quarry water treatment plant equalization basin.

DOE/OR/21548-730, Rev. 0 
The purpose of this sampling event was to provide information to determine the potential for surface water to influence groundwater quality at the quarry.

\subsection{Monitoring Results}

Analytical results of the monitoring of surface water and NPDES outfalls are presented in the following subsections.

\subsubsection{National Pollutant Discharge Elimination System Program Monitoring Results}

Radiochemical, chemical, and physical analytical results for NPDES outfalls are presented in subsections 7.6.1.1 and 7.6.1.2.

\subsubsection{Radiochemical Analysis}

The 1997 average uranium concentrations at the storm water discharge points ranged from $2.7 \mathrm{pCi} / 1(0.10 \mathrm{~Bq} / \mathrm{l})$ at $\mathrm{NP}-0010$ to $142.5 \mathrm{pCi} / 1(5.27 \mathrm{~Bq} / \mathrm{l})$ at $\mathrm{NP}-0003$, which are $0.40 \%$ and $21 \%$, respectively, of the DCG for natural uranium. Average annual gross alpha concentrations ranged from $5.78 \mathrm{pCi} / \mathrm{l}(0.21 \mathrm{~Bq} / \mathrm{l})$ at $\mathrm{NP}-0010$ to $96.8 \mathrm{pCi} / \mathrm{l}(3.58 \mathrm{~Bq} / \mathrm{l})$ at NP-0003. The annual average radionuclide concentrations for all the permitted storm water outfalls are shown in Table 7-3. Uranium concentration averages were calculated on a flow proportional basis for storm water outfalls except for Outfall NP-0010 where there is no totalizing flow meter. Flow weighted averages for uranium were calculated for the three major outfalls to give a more accurate estimate (instead of a straight average) of the total uranium that migrated off site during 1997. The averages were flow weighted by summing the total daily flows (gallons) for the days the samples were collected and summing the total activity $(\mathrm{pCi})$ for the days the samples were collected. The sum of the activity for all samples was then divided by the sum of the flow for all samples, to give the flow-weighted average for the year.

The site water treatment plant (SWTP) and quarry water treatment plant (QWTP) were both in operation during 1997. Three batches were discharged from the QWTP and eight batches were discharged from the SWTP. No daily maximum or monthly average limits are established for uranium; however, the design of the treatment plant is based on achieving an average of $30 \mathrm{pCi} / 1(1.11 \mathrm{~Bq} / \mathrm{l})$ uranium with a maximum never to exceed $100 \mathrm{pCi} / 1(3.7 \mathrm{~Bq} / \mathrm{l})$. The average uranium concentrations for the site and quarry water treatment plants were well below this level at $1.50 \mathrm{pCi} / 1(0.06 \mathrm{~Bq} / \mathrm{l})$ and $0.51 \mathrm{pCi} / 1(0.02 \mathrm{~Bq} / \mathrm{l})$, respectively (Table 7-5). In addition, the SWTP averaged $5.50 \mathrm{pCi} / 1(0.20 \mathrm{~Bq} / \mathrm{l})$ for gross alpha and $16.05 \mathrm{pCi} / 1(0.59 \mathrm{~Bq} / 1)$ for gross beta. The QWTP averaged $1.94 \mathrm{pCi} / 1(0.07 \mathrm{~Bq} / 1)$ and $6.74 \mathrm{pCi} / 1(0.25 \mathrm{~Bq} / \mathrm{l})$, respectively for these same 
Table 7-3 1997 Annual Average NPDES Results for the Weldon Spring Chemical Plant Storm Water Outfalls

\begin{tabular}{|l|c|c|c|c|}
\hline & \multicolumn{3}{|c|}{ LOCATIONS } \\
\hline PARAMETERS & NP-0002 & NP-0003 & NP-0005 & NP-0010 \\
\hline $\begin{array}{l}\text { Number of sample } \\
\text { events }\end{array}$ & 12 & 11 & 8 \\
\hline pH range & $(\mathrm{a})$ & $(\mathrm{a})$ & $(\mathrm{a})$ & $(\mathrm{a})$ \\
\hline Nitrate (as N) mg/l & 1.95 & 6.64 & 0.50 & 0.42 \\
\hline $\begin{array}{l}\text { Total suspended solids } \\
\text { mg/l }\end{array}$ & 613 & 262 & 46 & 120 \\
\hline Settleable solids m///hr & $12 / 2(\mathrm{~b})$ & $11 / 0(\mathrm{~b})$ & $12 / 0(\mathrm{~b})$ & $8 / 0(\mathrm{~b})$ \\
\hline Arsenic mg/l & 0.00551 & .00594 & 0.01508 & NS \\
\hline Chromium mg/l & 0.01506 & 0.01758 & 0.00452 & NS \\
\hline Lead mg/l & 0.00569 & 0.01302 & 0.00378 & NS \\
\hline Thallium mg/l & 0.00197 & 0.01115 & 0.00157 & NS \\
\hline Total uranium pCi/l & $14.4^{*}$ & $142.5 *$ & $18.9 *$ & 2.7 \\
\hline Gross alpha pCi/l & 29.5 & 96.8 & 30.8 & 5.78 \\
\hline Radium-226 pCi/l & 0.57 & 1.07 & 0.58 & NS \\
\hline Radium-228 pCi/l & 0.82 & 1.47 & 1.04 & NS \\
\hline Thorium-228 pCi/l & 0.31 & 0.65 & 0.17 & NS \\
\hline Thorium-230 pCi/l & 0.29 & 0.66 & 0.31 & NS \\
\hline Thorium-232 pCi/l & 0.28 & 0.58 & 0.09 & NS \\
\hline
\end{tabular}

(a) All pH readings were in the permitted range of 6.0 to 9.0 .

(b) Top number is number of samples, bottom number is number of results above daily maximum limit of $1.0 \mathrm{ml} / \mathrm{h} / \mathrm{hr}$.

- Flow proportional averages.

NS Not Sampled.

Note: $\quad 1 \mathrm{pCi} / \mathrm{l}=0.037 \mathrm{Bg} / \mathrm{l}$.

parameters (Table 7-4). In addition to effluent monitoring, the NPDES permit for the quarry, MO-0108987, required that river sediment sampling be conducted annually upstream and downstream of the quarry water treatment plant outfall (NP-1001). The river sediment was sampled for uranium at locations SD-4090 (upstream) and SD-4091 (downstream) (see Figure 7-3). The one-time sampling results were $1.58 \mathrm{pCi} / \mathrm{g}(0.06 \mathrm{~Bq} / \mathrm{g})$ at $\mathrm{SD}-4090$ and $1.01 \mathrm{pCi} / \mathrm{g}(0.04 \mathrm{~Bq} / \mathrm{g})$ at SD-4091.

Radium and thorium were monitored once per month, (as required by the permit) in both site and quarry water treatment batches. While there were some isolated incidents at the site water treatment plant of levels elevated above past averages, $(\mathrm{Ra}-226 \mathrm{had}$ a maximum value of $2.24 \mathrm{pCi} / 1[0.08 \mathrm{~Bq} / \mathrm{l}], \mathrm{Ra}-228 \mathrm{had}$ a maximum value of $3.1 \mathrm{pCi} / 1[0.12 \mathrm{~Bq} / \mathrm{l}]$, and $\mathrm{Th}-230 \mathrm{had}$ a maximum value of $2.47 \mathrm{pCi} / 1$ [0.09 Bq/1]), they were below $\mathrm{DCG}$ levels and returned to within normal range in subsequent samples. Annual averages for radium and thorium at the SWTP and QWTP are shown in Table 7-4.

Ac-227, Po-210 and Rn-222 were monitored one time in 1997 (as required) in the quarry effluent. Ac-227 had an uncensored value of $40.4 \mathrm{pCi} / 1 \pm 47.6(1.49 \mathrm{~Bq} / 1)$ with a detection limit of 
$72.2 \mathrm{pCi} / /(2.67 \mathrm{~Bq} / 1)$; however, the duplicate result was an uncensored value of $0.733 \pm 40.9 \mathrm{pCi} / 1$ $(0.03 \mathrm{~Bq} / \mathrm{l})$ with a detection limit of $52.0 \mathrm{pCi} / \mathrm{l}(1.9 \mathrm{~Bq} / \mathrm{l})$. Actinium analytical methods are not refined and give imprecise results. It is unlikely that Actinium is present in the QWTP effluent. Po-210 was detected at $0.631 \mathrm{pCi} / 1(0.002 \mathrm{~Bq} / \mathrm{l})$; and $\mathrm{Rn}-222$ was not detected (at a detection limit of $35.2 \mathrm{pCi} / 1[1.30 \mathrm{~Bq} / 1])$.

Table 7-4 Site and Quarry Water Treatment Plant Annual Averages for Radium and Thorium (pCi/l)

\begin{tabular}{|c|c|c|}
\hline PARAMETER & QUARRY WTP (NP-1001) & SITE WTP(NP-0007) \\
\hline Ra-226 & $0.46(0 / 3)^{*}$ & $1.10(2 / 6)^{\star}$ \\
\hline Ra-228 & $1.72(2 / 3)$ & $2.44(2 / 6)$ \\
\hline Th-228 & $0.09(3 / 3)$ & $0.21(4 / 6)$ \\
\hline Th-230 & $1.24(2 / 3)$ & $0.72(3 / 6)$ \\
\hline Th-232 & $0.05(3 / 3)$ & $0.14(6 / 6)$ \\
\hline Gross alpha & $1.94(2 / 3)$ & $5.50(2 / 8)$ \\
\hline Gross beta & $6.74(0 / 3)$ & $16.05(0 / 8)$ \\
\hline
\end{tabular}

* Number of results below detection limit (including uncensored values)/total number of samples.

Note: $\quad 1 \mathrm{pCi} /=0.037 \mathrm{~Bq} / \mathrm{l}$

Estimated quantities of total natural uranium released off site through surface water runoff and treatment plant discharges are presented in Table 7-5. The total volume of storm water at the three major outfalls was measured with totalizing flow meters. Where flow meters were not available, the flow was determined by total precipitation and runoff curve numbers cited in the U.S. Department of Transportation Design of Roadside Drainage Channels (Ref. 55). When flow meters were not operational for a period of time, runoff curve numbers were calculated using flow and precipitation data from periods when the meter was operational. Total uranium released from the treatment plants was calculated using flow meter and effluent concentration data. The estimated mass of uranium released off site in storm water and treated effluent during 1997 was $22.15 \mathrm{~kg}$ (48.83 lbs). This is a reduction from the calculated amount released during 1996 $(38.34 \mathrm{Kg}[84.52 \mathrm{lb}])$. This reduction may be attributed to the removal of foundations and contaminated soils during 1997.

Table 7-6 shows the annual average uranium concentrations of NPDES outfalls from 1991 to 1997. Concentrations in 1997 increased at Outfall NP-0003 and decreased from 1996 concentrations at Outfalls NP-0002, NP-0005 and NP-0010. Historical trending of uranium for Outfalls NP-0002, NP-0003, and NP-0005 is discussed in Section 11.1. Radium and thorium were both periodically monitored at Outfalls NP-0002, NP-0003, and NP-0005 throughout the year to monitor the effects and effectiveness of soil and foundation removal. The parameters for each outfall are discussed in the succeeding paragraphs. 
Outfall NP-0001 was the outlet of the abandoned process sewer outfall line. Outfall NP-0001 was physically eliminated during May 1994 and was officially eliminated from the permit on August 4, 1995.

The average uranium concentration for Outfall NP-0002 in 1997 was $14.4 \mathrm{pCi} /$ $(0.53 \mathrm{~Bq} / \mathrm{l})$, reduced from the 1996 average of $53.6 \mathrm{pCi} / 1(2.0 \mathrm{~Bq} / 1)$. This reduction is the result of the removal of contaminated soil from the watershed throughout 1996 which was the only instance where radium or thorium was above baseline. Th- 230 was above baseline in one sample. Baseline values for contaminants in storm water were set before soil and foundation removal started. Baseline monitoring and values are discussed in Section 11.2. All levels were below the DCGs. Annual average NPDES results for the Outfall NP-0002 are shown in Table 7-3.

Table 7-5 1997 Estimated Annual Release of Natural Uranium from NPDES Outfalls

\begin{tabular}{|c|c|c|c|c|c|c|c|}
\hline OUTFALL & $\begin{array}{l}\text { DRAINAGE } \\
\text { AREA } \\
\text { HECTARES } \\
\text { (ACRES) }\end{array}$ & $\begin{array}{c}\text { ESTIMATED } \\
\% \text { OF } \\
\text { PRECIPITATION } \\
\text { AS RUNOFF } \\
\end{array}$ & $\begin{array}{c}\text { AVERAGE URANIUM } \\
\text { CONCENTRATION } \\
\text { (PCI/L) }\end{array}$ & $\begin{array}{c}\text { TOTAL } \\
\text { RAINFALL } \\
\text { VOLUME } \\
\text { Ml/yr } \\
\text { (Mgal/yr) }\end{array}$ & $\begin{array}{c}\text { TOTAL } \\
\text { DISCHARGE } \\
\text { Ml/yr } \\
\text { (Mgal/yr) } \\
\end{array}$ & $\begin{array}{c}\text { TOTAL U } \\
\text { RELEASE } \\
\text { (Ci/yr) }\end{array}$ & $\begin{array}{c}\text { TOTAL U } \\
\text { RELEASE } \\
(\mathrm{Kg} / \mathrm{yr}) \\
\end{array}$ \\
\hline NP-0002 & \begin{tabular}{|c|}
30.4 \\
$(75.1)$ \\
\end{tabular} & (b) & $14.4^{*}$ & $\begin{array}{l}243.13 \\
(64.23) \\
\end{array}$ & $\begin{array}{r}104.69 \\
(27.62) \\
\end{array}$ & $1.56 \times 10^{-3}$ & 2.290 \\
\hline NP-0003 & $\begin{array}{c}30.2 \\
(74.6)\end{array}$ & (b) & $142.5^{*}$ & $\begin{array}{l}241.51 \\
(63.81)\end{array}$ & $\begin{array}{c}91.66 \\
(24.19)\end{array}$ & $13.06 \times 10^{-3}$ & 19.218 \\
\hline NP-0005 & $\begin{array}{c}8.2 \\
(20.2)\end{array}$ & (b) & $18.9^{*}$ & $\begin{array}{c}65.4 \\
(17.28)\end{array}$ & $\begin{array}{l}18.91 \\
(4.99)\end{array}$ & $0.36 \times 10^{-3}$ & 0.526 \\
\hline NP-0010 & $\begin{array}{c}2.0 \\
(5.0)\end{array}$ & $40^{(a)}$ & 2.7 & $\begin{array}{l}16.20 \\
(4.28)\end{array}$ & $\begin{array}{c}6.48 \\
(1.71)\end{array}$ & $0.017 \times 10^{-3}$ & 0.026 \\
\hline NP-0007 & N/A & N/A & 1.50 & N/A & $\begin{array}{l}36.74 \\
(9.71)\end{array}$ & $0.055 \times 10^{-3}$ & 0.081 \\
\hline NP-1001 & N/A & N/A & 0.51 & N/A & $\begin{array}{l}13.21 \\
(3.49) \\
\end{array}$ & $0.007 \times 10^{-3}$ & 0.010 \\
\hline TOTAL & N/A & $\bar{N} / \mathrm{A}$ & N/A & $\begin{array}{c}566.24 \\
(149.59)\end{array}$ & $\begin{array}{l}271.69 \\
(71.78)\end{array}$ & $15.059 \times 10^{-3}$ & 22.151 \\
\hline
\end{tabular}

(a) Runoff curve number estimated from U.S. Department of Transportation Design of Roadside Drainage Channels (Ref. 55).

(b) Total runoff measured from flow meters.

NiA Not Applicable.

Note: To convert from Cilyr to Bq/yr multiply Ci/yr by $3.7 \times 10^{10}$

* Flow-weighted average. 
Table 7-6 Six-Year Annual Average Uranium Concentrations at NPDES Outfalls

\begin{tabular}{|c|c|c|c|c|c|c|c|}
\hline \multirow[t]{2}{*}{ OUTFALL } & \multicolumn{6}{|c|}{ ANNUAL AVERAGE TOTAL URANIUM (pCi/l) } & \multirow[b]{2}{*}{1997} \\
\hline & 1991 & 1992 & 1993 & 1994 & 1995 & 1996 & \\
\hline NP-0001 & 475 & 516 & $1003^{*}$ & $1226^{*}$ & (a) & (a) & (a) \\
\hline NP-0002 & 158 & 228 & $230^{\star}$ & $182^{*}$ & $124^{*}$ & $54^{*}$ & $14^{*}$ \\
\hline NP-0003 & 456 & 478 & $607^{*}$ & $332^{*}$ & $67^{*}$ & $88^{*}$ & $143^{*}$ \\
\hline NP-0004 & 6 & 6 & 9 & 12 & (10) & (ह) & (b) \\
\hline NP-0005 & 581 & 296 & $133^{*}$ & $347^{\star}$ & $128^{*}$ & $107^{*}$ & $19^{*}$ \\
\hline NP-0010 & - & - & - & 82 & 107 & 50 & 2.7 \\
\hline NP-0007 & - & - & 0.363 & 0.74 & 0.46 & 1.37 & 1.50 \\
\hline NP-1001 & - & $<0.0003$ & 1.881 & 1.60 & 1.76 & 1.09 & 0.51 \\
\hline
\end{tabular}

- Flow proportional average.

- Not applicable.

(a) Outfall removed, flow diverted to NP-0005.

(b) Outfall removed from permit in 1995.

The average uranium concentration for Outfall NP-0003 was $142.5 \mathrm{pCi} / 1(5.27 \mathrm{~Bq} / \mathrm{l})$, which was somewhat greater than the 1996 average of $88.1 \mathrm{pCi} / 1$ (3.26 Bq/1). The increase is the result of an increase in uranium concentration in the runoff from Ash Pond. Ash Pond is used to store materials removed from other areas of the site until they can be placed in the cell. Ash Pond is managed to avoid discharging water that is over $600 \mathrm{pCi} / \mathrm{l}$ from the pond; however, the concentration may be higher than previous years causing an increase in average uranium concentration at Outfall NP-0003. Except for Ra-228 in one sample, radium and thorium concentrations were below baseline values (see Tables 11-2 and 11-3). All values were well below the DCGs for radium and thorium. Annual average values for uranium, radium, thorium, and gross alpha are shown in Table 7-3. Baseline values are discussed in Section 11.1.3. One major contribution to NP-0003 is water that flows around Ash Pond before entering sediment at Basin 4 is the diversion channel that collects water from upstream of Ash Pond. The diversion channel was sampled just before it entered Sedimentation Basin 4 to determine the uranium contribution to Outfall NP-0003. The annual average at SW-2017 was $85.8 \mathrm{pCi} /$, which was lower than the Outfall NP-0003 average of 143 pCi/l. Location SW-2017 results are located in Table 7-7.

Outfall NP-0004 was eliminated from NPDES permit MO-0107701 on March 4, 1994. No samples were collected during 1997.

The annual average uranium concentration at Outfall NP-0005 for 1997 was $18.9 \mathrm{pCi} / 1$ $(0.70 \mathrm{~Bq} / \mathrm{l})$, which was much less than the 1996 average of $106.7 \mathrm{pCi} / \mathrm{l}(3.95 \mathrm{~Bq} / \mathrm{l})$. Removal of contaminated foundations and soil from the watershed was completed during 1996 allowing 1997 results to be greatly reduced over 1996 results. Radium and thorium concentrations were below 
baseline values. Annual average NPDES results are shown in Table 7-3 and baseline values are discussed in Section 11.2.

Outfall NP-0010 was added to NPDES Permit MO-0107701 when it was reissued on March 4, 1994. This outfall is located near the west end of the north perimeter fence in the construction material staging area (CMSA), and drains a portion of the CMSA. The CMSA is used to store clean soil, gravel, and other construction material. Contaminated soil was removed and the CMSA was completed early in 1996; therefore the area was clean for all of 1997 . The annual average uranium concentration was $2.7 \mathrm{pCi} / 1(0.10 \mathrm{~Bq} / \mathrm{l})$, well below the $\mathrm{DCG}$ of $600 \mathrm{pCi} / 1$ $(22.2 \mathrm{~Bq} / \mathrm{l})$ and the 1996 average of $50 \mathrm{pCi} / 1(1.85 \mathrm{~Bq} / \mathrm{l})$. Radium and thorium were not suspected, and therefore, were not measured at NP-0010. The annual average NPDES results are reported in Table 7-3.

The MSA pond (SW-2015) was sampled quarterly for gross alpha, uranium, Ra-226, Ra-228, Th-228, Th-230, and Th-232 to monitor the contaminants in storm water runoff from the MSA. Monitoring also allowed determination of potential impacts on Outfall NP-0003. The uranium average was $191 \mathrm{pCi} / 1(7.1 \mathrm{~Bq} / \mathrm{l})$, slightly higher than the 1996 average of $134.8 \mathrm{pCi} / 1$ $(5.0 \mathrm{~Bq} / \mathrm{l})$, but well below the release criteria of $600 \mathrm{pCi} / \mathrm{l}(22.2 \mathrm{~Bq} / \mathrm{l})$. Radium and thorium were measured at low levels, well below DCG values. The annual average radiological concentrations are reported in Table 7-7.

Table 7-7 MSA, Ash Pond and Frog Pond - 1997 Annual Average Radiological Concentrations $(p \mathrm{Ci} / \mathrm{l})$

\begin{tabular}{|l|c|c|c|c|c|}
\hline $\begin{array}{c}\text { LOCATION } \\
\text { PARAMETER }\end{array}$ & $\begin{array}{c}\text { MSA POND } \\
\text { SW-2015 }\end{array}$ & $\begin{array}{c}\text { ASH POND } \\
\text { SW-2010 }\end{array}$ & $\begin{array}{c}\text { FROG POND } \\
\text { SW-2011 }\end{array}$ & $\begin{array}{c}\text { SED. BASIN 1 } \\
\text { SW-2019 }\end{array}$ & $\begin{array}{c}\text { DIVERSION CHANNEL } \\
\text { SW-2017 }\end{array}$ \\
\hline Ra-226 & 0.6 & 0.6 & NS & NS & NS \\
\hline Ra-228 & 1.5 & 1.7 & NS & NS & NS \\
\hline Th-228 & 0.1 & 0.1 & NS & NS & NS \\
\hline Th-230 & 0.3 & 0.8 & NS & NS & NS \\
\hline Th-232 & 0.1 & 0.2 & NS & NS & NS \\
\hline U & 191 & 484 & 620 & 7.8 & NS \\
\hline Gross alpha & 204 & 809 & NS & NS & NS \\
\hline
\end{tabular}

NS Not Sampled.

Ash Pond (SW-2010) was sampled quarterly, when water was flowing, for gross alpha, uranium, Ra-226, Ra-228, Th-228, Th-230, and Th-232 to monitor the effects of demolition debris and soil stored in Ash Pond on Ash Pond runoff and subsequently, on the downstream outfall, NP-0003. Monitoring was performed in conjunction with the NPDES sampling at Outfall NP-0003. The pond was also monitored for uranium and gross alpha when the monthly NPDES sample was collected at Outfall NP-0003. The uranium average at Ash Pond was $484 \mathrm{pCi} / 1$ $(17.9 \mathrm{~Bq} / \mathrm{l})$, somewhat higher than the 1996 average of $391 \mathrm{pCi} / \mathrm{l}(14.5 \mathrm{~Bq} / \mathrm{l})$ and below the $\mathrm{DCG}$ 
of $600 \mathrm{pCi} / 1(22.2 \mathrm{~Bq} / \mathrm{l})$. Radium and thorium were measurable but at levels well below the DCG. Table 7-7 contains the annual average radiological concentrations.

Frog Pond (location SW-2011) was sampled for uranium in conjunction with monthly NPDES sampling at Outfall NP-0002. The uranium average for 1997 was $620 \mathrm{pCi} / \mathrm{l}(22.9 \mathrm{~Bq} / \mathrm{l})$, much greater than the 1996 average of $276.4 \mathrm{pCi} / 1$. The increase was likely due to the elimination of less contaminated water flowing to the pond and greater retention times in the pond (due to the greatly reduced flow into the pond). Even though this is a substantial increase, the volume of water discharging from Frog Pond is very small as evidenced by the substantial reduction for uranium at Outfall NP-0002 (downstream of Frog Pond). Frog Pond was essentially isolated by diverting potential inflow around the pond, and its role as a contributor to Outfall NP-0002 was greatly reduced. Other than runoff from the immediate area and direct precipitation, no water enters Frog Pond. The outlet of Sedimentation Basin 1 (SW-2019) was also monitored. Sedimentation Basin 1 discharges to the channel that leads to Outfall NP-0002 and makes up most of the flow at NP-0002. The sedimentation basin effluent was monitored to determine the contribution of the watershed flowing to the basin to NP-0002 uranium levels. The annual average for uranium was $7.8 \mathrm{pCi} /$, which is below the $\mathrm{NP}-0002$ average of $14 \mathrm{pCi} / \mathrm{l}$. Table 7-7 contains the annual average radiological concentrations.

Location NP-0107 was previously sampled as an upstream location but has been deleted. In mid-1996, the watershed above NP-0107 was remediated and, because of a change in grade, no water flowed from the NP-0107 location during 1997.

\subsubsection{Physical and Chemical Results}

Analytical results for physical and chemical (as opposed to radiochemical) parameters at NPDES outfalls and other sample locations are presented in Subsections 7.6.1.2.1 through 7.6.1.2.4.

\subsection{Chemical Plant Storm Water}

The annual averages for the physical and chemical parameters for storm water Outfalls NP-0002, NP-0003, NP-0005, and NP-0010 are shown in Table 7-3. In addition to the permitted parameters, arsenic, chromium, lead, and thallium were periodically monitored. While some parameters were present above baseline levels (see Section 11.1.3), with the exception of one chromium level at Outfall NP-0003 $(111 \mu \mathrm{g} / \mathrm{l})$ they were not above NPDES reporting levels.

Ash Pond (SW-2010) was sampled quarterly for polycyclic (or polynuclear) aromatic hydrocarbons (PAH), As, Cr, Pb, Tl, 2,4-Dinitrotoluene (DNT), and 2,4,6-Trinitrotoluene (TNT) to monitor the effect of demolition debris and soils in Ash Pond on contaminants in the Ash Pond storm water runoff. Nitrate (as N) was also monitored. Should contaminant concentrations 
appear to be increasing, monitoring frequencies would be increased. If increased monitoring were to indicate that Ash Pond water would cause contaminant levels at Outfall NP-0003 to exceed permit limits or reporting levels, a valve in the Ash Pond discharge structure would be closed and the water retained. Analytical results are shown in Table 7-8.

The MSA Pond (SW-2015) was sampled quarterly for the same parameters as Ash Pond to monitor the effects of material stored at the MSA on storm water runoff to the MSA pond. The monitoring results are used to determine whether MSA water could cause contaminant levels at Outfall NP-0003 to exceed permit limits or reporting levels. If it appeared that contaminant concentrations were increasing, then monitoring frequencies would be increased and water that would adversely affect Outfall NP-0003 would not be released. Analytical results are shown in Table 7-8.

Table 7-8 Ash and MSA Pond - 1997 Annual Average Chemical Concentrations $(\mu \mathrm{g} / \mathrm{l})$

\begin{tabular}{|c|c|c|}
\hline \multirow[t]{2}{*}{ PARAMETER } & \multicolumn{2}{|c|}{ LOCATION } \\
\hline & $\begin{array}{l}\text { ASH POND } \\
(S W-2010)\end{array}$ & $\begin{array}{l}\text { MSA POND } \\
(S W-2015)\end{array}$ \\
\hline PAHs & $<23^{*}$ & $<1^{t+k}$ \\
\hline As & 2.6 & 2.2 \\
\hline $\mathrm{Cr}$ & 5.7 & 2.8 \\
\hline $\mathrm{TI}$ & 1.6 & 3.9 \\
\hline $\mathrm{Pb}$ & 3.2 & 4.4 \\
\hline PCBs & $<1^{* t}$ & $<1^{\prime}$ \\
\hline 2,4-DNT & $<0.1^{*}$ & $<0.1^{*}$ \\
\hline $2,4,6-\mathrm{TNT}$ & $<0.1^{\star}$ & $<0.1^{\star}$ \\
\hline Nitrate (as N) & $4.85 \mathrm{mg} / \mathrm{l}$ & NS \\
\hline
\end{tabular}

NS Not sampled

- All ND

* D.L for one parameter was 2.

*** All ND except for one detection of fluorene at $1.32 \mu \mathrm{g} / \mathrm{l}$

All ND except for one detection each for Aroclor-1254 at $0.49 \mu \mathrm{g} / \mathrm{l}$ and Aroclor-1260 at $0.32 \mu \mathrm{g} / \mathrm{l}$

\subsection{Administration Building Sewage Treatment Plant}

Monitoring results for the sewage treatment plant Outfall NP-0006 are given in Table 7-9. For the second quarter, BOD was out of compliance due to a plant upset. An initial compliance sample disclosed the upset and two subsequent samples collected to monitor progress in bringing the plant back into compliance were also out of compliance. The biological growth was reestablished and subsequent samples demonstrated that the plant was operating properly and was in compliance. All other parameters were in compliance during the year. 


\subsection{Site and Quarry Water Treatment Plant Physical and Chemical Parameters}

Physical and chemical parameters were all within permitted limits (where limits were assigned) for the site and quarry water treatment plants.

During 1997, whole effluent toxicity (WET) tests were required quarterly for both the site water treatment plant, and quarry water treatment plant effluent. The WET test is a measure of toxicity without quantifying or identifying the toxic constituents. Tests were conducted on both Ceriodaphnia dubia (water flea) and Pimephales promelas (fathead minnow). The tests were conducted in effluents and in test controls of upstream river water and laboratory control water. No effluent samples failed the WET tests during 1997, indicating that the site and quarry water treatment plant effluents were not toxic to test organisms (see Table 7-2). Whole effluent toxicity test results are summarized in Table 7-10.

Since treatment plant effluent is not discharged if parameter levels are above permitted limits, the parameter levels are not summarized here.

Table 7-9 NP-0006, Sewage Treatment Plant Outfall, Monthly Averages of Permitted Parameters

\begin{tabular}{|l|c|c|c|c|}
\hline & \multicolumn{4}{|c|}{ PARAMETER(a) (PERMIT LIMITS) } \\
\hline MONTH & $\begin{array}{c}\text { TSS } \\
(30 / 45 \mathrm{mg} /)^{*}\end{array}$ & $\begin{array}{c}\text { BOD } \\
(30 / 45 \mathrm{mg} /)^{*}\end{array}$ & $\begin{array}{c}\text { FC(b) } \\
(400 / 1000 \\
(00 / / 100 \mathrm{ml})^{* *}\end{array}$ & $\mathrm{pH}(6.0-9.0 \mathrm{SU})$ \\
\hline January & 7 & $<10$ & 1 & $(\mathrm{c})$ \\
\hline April & 11.0 & $77.2^{* * *}$ & $\mathrm{~N}$ & (c) \\
\hline June & 7.5 & 13.0 & $<1$ & (c) \\
\hline July & 2.0 & 3.6 & $<1$ & (c) \\
\hline October & 9.0 & 12.1 & (c) & (c) \\
\hline
\end{tabular}

(a) One sample analyzed for each month noted.

(b) F.C - fecal coliform.

(c) $\mathrm{pH}$ values were between 6.0 and 9.0 .

NS Not Sampled

- Monthly average/weekly average

* Monthly average/daily maximum

Three samples.

Table 7-10 1997 Whole Effluent Toxicity Test Results for the Site and Quarry Water Treatment Plants*

\begin{tabular}{|c|c|c|c|c|c|}
\hline BATCH & DATE & $\begin{array}{c}\text { DAPHNIA (D)\% } \\
\text { MORTALITY }\end{array}$ & $\begin{array}{c}\text { PIMEPHALES } \\
\text { (P) }\end{array}$ & $\begin{array}{c}\text { RIVER } \\
\text { CONTROL D,P } \\
\% \text { MORTALITY }\end{array}$ & $\begin{array}{c}\text { LAB CONTROL } \\
\text { D,P \% } \\
\text { MORTALITY }\end{array}$ \\
\hline S095 & $02 / 12 / 97$ & 0 & 0 & 0,0 & $0,2.5$ \\
\hline$S 099$ & $04 / 24 / 97$ & 0 & 2.5 & $0,2.5$ & 0,0 \\
\hline$S 102$ & $09 / 15 / 97$ & 0 & 0 & $0,2.5$ & 0.0 \\
\hline 0048 & $03 / 13 / 97$ & 0 & 0 & 0,0 & 0,0 \\
\hline $\mathrm{Q} 049$ & $07 / 14 / 97$ & 0 & 0 & 0.0 & $0,2.5$ \\
\hline $\mathrm{Q} 050$ & $09 / 11 / 97$ & 0 & 0 & 0.0 & 0.0 \\
\hline
\end{tabular}


Table 7-10 1997 Whole Effluent Toxicity Test Results for the Site and Quarry Water Treatment Plant* (Continued)

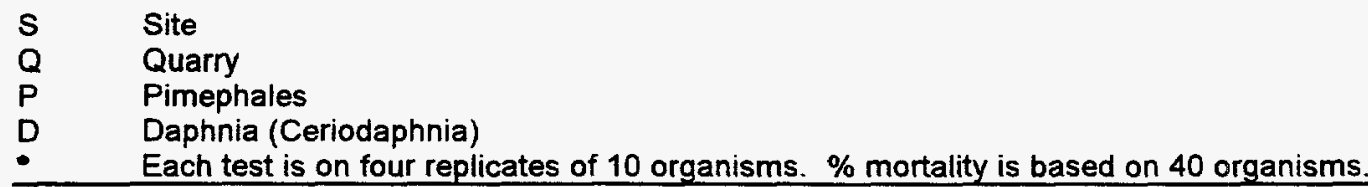

\subsection{Hydrostatic Test Water Results}

NPDES permit MO-G670203 was issued on December 5, 1997, for the discharge of hydrostatic test water. The permit requires that a sample be collected during the first 60 minutes of each discharge. The permit requires that flow, total petroleum hydrocarbons (TPH), TSS and $\mathrm{pH}$ be monitored. There is a daily maximum and monthly average for TSS and TPH; however, the monthly average and daily maximum are the same. The limit for TPH is $10 \mathrm{mg} / \mathrm{l}$ and for TSS $100 \mathrm{mg} / \mathrm{l}$. The $\mathrm{pH}$ is limited to a range of 6.0 to 9.0 . The discharge monitoring report is required to be submitted annually with the first report due October 28,1998 , for the pefiod October 1 , 1997, to September 31, 1998. During 1997, there was only one discharge of hydrostatic test water. The discharge took place on December 19, 1997. The total volume discharged was $190,000 \mathrm{gal}$. All parameters were in compliance with the permitted limits. TPH was $<0.170 \mathrm{mg} / \mathrm{l}$, TSS was $7.0 \mathrm{mg} / 1$ and $\mathrm{pH}$ was 7.40 .

\subsection{Borrow Area and Haul Road Land Disturbance Results}

NPDES permit MO-R100B69 was issued on September 1, 1994, and has no specified monitoring or reporting requirements. The 1997 Environmental Monitoring Plan (Ref. 42), however, requires that settleable solids be monitored once every calendar quarter and oil and grease be monitored as indicated by operations at the facility. Oil and grease was sampled only one time with a result of $2.04 \mathrm{mg} / \mathrm{l}$ at Outfall NP-0040 (Borrow Area north sedimentation basin outfall). The haul road was stabilized during 1996 and no samples were collected at those outfalls. Settleable solids results are shown in Table 7-11. All monitoring results were below the reporting levels set in the Environmental Monitoring Plan (Ref. 42). Settleable solids were all less than $1.0 \mathrm{ml} / \mathrm{l} / \mathrm{hr}$, which is the standard permit limit when limits are set. The oil and grease results were also below the standard $10 \mathrm{mg} / \mathrm{l}$ limit.

Table 7-11 Borrow Area Settleable Solids $(\mathrm{ml} / \mathrm{h} / \mathrm{hr})$

\begin{tabular}{|c|c|c|}
\hline DATE & \multicolumn{2}{|c|}{ LOCATIONS } \\
\hline & NP-0040* & NP-0046** $^{* *}$ \\
\hline $02 / 26 / 97$ & 0.5 & 0.2 \\
\hline $04 / 11 / 97$ & $<0.1$ & $<0.1$ \\
\hline $05 / 19 / 97$ & $<0.1$ & NS \\
\hline $08 / 15 / 97$ & 0.2 & NS \\
\hline
\end{tabular}


Table 7-11 Borrow Area Settleable Solids (ml///hr) (Continued)

\begin{tabular}{|c|c|c|}
\hline DATE & LOCATIONS \\
\hline & NP-0040 & NP-0046 \\
\hline $09 / 17 / 97$ & 0.5 & $\mathrm{NS}$ \\
\hline $11 / 05 / 97$ & 0.5 & $<0.1$ \\
\hline $11 / 06 / 97$ & 0.1 & $<0.1$ \\
\hline $12 / 03 / 97$ & $<0.1$ & $<0.1$ \\
\hline
\end{tabular}

- $\quad$ North Borrow Area sedimentation basin.

* East Borrow Area sedimentation basin.

\subsubsection{Surface Water Monitoring Results}

Analytical results for surface water monitoring locations at the chemical plant site and quarry are presented in Subsections 7.6.2.1 and 7.6.2.2.

\subsubsection{Weldon Spring Chemical Plant and Weldon Spring Raffinate Pits}

Average uranium levels at off-site surface water locations were lower at five locations and only slightly higher (than the 1996 annual averages) at two others. Overall, the uranium concentrations were reduced over 1996 levels. This is attributed to the fact that large areas of the site have been remediated and uranium levels at the NPDES outfalls have decreased overall. Because the Busch Lakes are large bodies of water, reduction in uranium levels at the lakes and downstream will significantly lag behind reductions in uranium at the NPDES outfalls. Average annual uranium concentrations for surface water are shown in Table 7-12, along with the 1996 figures and the historic high for the location for comparison. Surface water locations are shown in Figure 7-1.

Table 7-12 Annual Averages for Total Uranium (pCi/l) Concentrations at Weldon Spring Chemical Plant Area Surface Water Locations*

\begin{tabular}{|l|c|c|c|c|}
\hline LOCATION & AVERAGE & MAXIMUM & MINIMUM & HISTORIC HIGH \\
\hline SW-2001 & $2.4(1.4)$ & $3.4(2.5)$ & $1.6(0.3)$ & $10(1993)$ \\
\hline SW-2002 & $8.2(29.5)$ & $11.4(55.8)$ & $5.4(7.9)$ & $390(1994)$ \\
\hline SW-2003 & $6.7(15.3)$ & $10.4(23.7)$ & $3.9(5.8)$ & $69(1988)$ \\
\hline SW-2004 & $10.0(14.1)$ & $11.2(16.9)$ & $8.2(7.3)$ & $39(1989)$ \\
\hline SW-2005 & $13.3(27.8)$ & $18.7(53.7)$ & $8.8(13.0)$ & $53.7(1996)$ \\
\hline SW-2012 & $6.3(6.5)$ & $9.5(11.2)$ & $3.6(2.8)$ & $326(1991)$ \\
\hline SW-2016 & $2.2(2.0)$ & $3.0(4.5)$ & $1.1(0.8)$ & $7.8(1994)$ \\
\hline
\end{tabular}

1996 results are given in parenthesis.

* Lake 36 was empty for all of 1997 . Samples collected of water flowing in and out.

Note 1: $1 \mathrm{pCi} / \mathrm{l}=0.037 \mathrm{~Bq} / \mathrm{l}$.

Note 2: Four samples were collected from each location during the year. 


\subsubsection{Weldon Spring Quarry}

Total Uranium.

The average total uranium values continue to indicate that the highest levels are found in the portion of the Femme Osage Slough (SW-1003, SW-1004 SW-1005 and SW-1010) downgradient of the quarry. The annual averages for the surface water locations are summarized in Table 7-13. The uranium levels in the Femme Osage Slough are within historical ranges. No new historic total uranium high concentrations were reported for quarry surface water during 1997.

Table 7-13 Annual Averages for Total Uranium $(\mathrm{pCi} / \mathrm{l})$ at Weldon Spring Quarry Surface Water Monitoring Locations*

\begin{tabular}{|l|c|c|c|c|}
\hline LOCATION & $\begin{array}{c}\text { ANNUAL } \\
\text { AVERAGE }\end{array}$ & MAXIMUM & MINIMUM & HISTORIC HIGH \\
\hline SW-1003 & $30.27(26.73)$ & $42.29(49.61)$ & $21.10(16.62)$ & $252(1989)$ \\
\hline SW-1004 & $28.44(34.24)$ & $55.81(77.59)$ & $23.34(17.35)$ & $4000(1993)$ \\
\hline SW-1005 & $23.87(16.46)$ & $29.80(27.48)$ & $18.52(8.47)$ & $116(1991)$ \\
\hline SW-1007 & $5.64(9.83)$ & $7.78(14.87)$ & $4.11(6.64)$ & $69(1992)$ \\
\hline SW-1009 & $4.37(6.25)$ & $6.41(7.92)$ & $3.34(1.85)$ & $28.6(1991)$ \\
\hline SW-1010 & $19.83(18.65)$ & $21.20(25.74)$ & $19.07(11.8)$ & $156(1991)$ \\
\hline
\end{tabular}

* 1996 results given in parentheses

Note: $1 \mathrm{pCi} / \mathrm{l}=0.037 \mathrm{~Bq} / \mathrm{l}$

Nitroaromatic Compounds

Nitroaromatic compounds were analyzed at SW-1003, SW-1004, and SW-1005 in the Femme Osage Slough. No detectable levels were observed for any of the six compounds monitored during 1997. 


\section{GROUNDWATER MONITORING}

\subsection{Highlights of the Groundwater Monitoring Program}

The following are highlights of the 1997 groundwater monitoring program. These items, and others, are discussed in detail in this chapter.

- Contaminant levels generally remained within historic ranges at all chemical plant locations.

- Raffinate pit area enhanced monitoring indicated increased nitrate concentrations in groundwater resulting from raffinate pit remedial action. No other impacts were detected.

- Monitoring results for Burgermeister Spring were generally within historical ranges. No new highs or lows were recorded, and no significant changes are apparent.

- Volatile organic compounds (VOC) trichloroethene and dichloroethene detected in groundwater in 1996 at the chemical plant continued to be under investigation during 1997 to determine the source and extents of contamination. The VOC concentrations decreased in monitor wells nearest the raffinate pits and increased in some locations south of the pits.

- Data for 1997 indicated that the level of nitroaromatic compounds continues to decrease in the groundwater at the quarry as a result of bulk waste removal. Average reductions of $40 \%$ of trinitrotoluene (TNT) and $18 \%$ of dinitrotoluene (DNT) were recorded for quarry rim wells from 1996 to 1997.

- Trending analyses for 1997 nitrate and nitroaromatic data from the chemical plant indicated new upward or downward trends. The instability of contaminant concentrations is believed to be responses to recent remediation activities.

- Environmental monitoring indicated that the greatest amount of radiochemical and nitroaromatic contamination in the groundwater is present in the bedrock of the quarry rim and the alluvial materials and bedrock north of the Femme Osage Slough.

- South of the slough and in the St. Charles County production wells total uranium concentrations in groundwater remained within background ranges, and no detectable concentrations of nitroaromatic compounds were identified. 
- With the exception of MW-1031 (for uranium) nitroaromatic compounds and total uranium concentrations in groundwater continued to decrease at locations previously described as having downward trends at the quarry.

- Samples from quarry rim wells in 1997 averaged greater than $10 \%$ lower uranium concentrations than in 1996, suggesting bulk waste removal successfully removed contaminant sources.

\subsection{Program Overview}

The groundwater monitoring and protection program at the Weldon Spring Site Remedial Action Project (WSSRAP) includes sampling and analysis of water collected from wells at the Weldon Spring Chemical Plant and raffinate pits, the Weldon Spring Quarry, vicinity properties, and from selected springs in the vicinity of the Weldon Spring site. The groundwater protection program is formally defined in the Groundwater Protection Program Management Plan (Ref. 13). The groundwater monitoring portion of the program is detailed in the Environmental Monitoring Plan (EMP) (Ref. 42).

Due to lithologic differences, including those geologic features that influence groundwater flow mechanics, and the geographical separation of the chemical plant and quarry areas, separate groundwater monitoring programs have been established for the two sites. Generalized geologic and hydrologic descriptions of the two sites are found in Section 1.3. A generalized stratigraphic column for reference is provided in Figure 8-1, and hydrogeologic descriptions of lithologies monitored for the program are in Section 8.4.

\subsection{Referenced Standards}

Two criteria used to develop the criteria for the groundwater monitoring program are: (1) the U.S. Environmental Protection Agency (EPA) Quality Criteria for Water 1986 (Ref. 35), which is intended to protect public groundwater resources, and (2) the Missouri Drinking Water Standards (Ref. 36). These standards are mainly used for comparison of levels observed in the St. Charles County well field. Table 8-1 identifies EPA water quality standards and Missouri Drinking Water Standards for contaminants that are routinely monitored in the groundwater program. Maximum contaminant levels (MCLs) and other drinking water standards are used only as references by the WSSRAP. The affected groundwater does not represent a public drinking water supply as defined in 40 CFR, Part 141, Subpart A - General.

Groundwater is also monitored under the requirements of Department of Energy Order 5400.5, Radiation Protection of the Public and the Environment, which designates derived 


\begin{tabular}{|c|c|c|c|c|c|c|}
\hline SYSTEM & SERIES & $\begin{array}{c}\text { STRATIGRAPHIC } \\
\text { UNIT }\end{array}$ & $\begin{array}{l}\text { TYPICAL } \\
\text { THICKNESS } \\
\text { (FI. J1) }\end{array}$ & LITHOLOGY & PHYSICAL CHARACTERISTICS & HYDROSTRATIGRAHIC UNIT \\
\hline \multirow{2}{*}{ QUATERNARY } & HOLOCENE & ALLUVIUM & $0-120$ & & GRAVELLY, SILTY LOAM. & ALLUVIAL AQUIFER \\
\hline & PLEISTOCENE & $\begin{array}{l}\text { LOESS ANO } \\
\text { OLACINL ORIFT (2) }\end{array}$ & $10-60$ & VAR & $\begin{array}{l}\text { SILTY CLAY, GRAVELLY CLAY, SILTY LOAM, OR } \\
\text { LOAM OVEA RESIOUUM FAOM WEATHEAED OEOROCK. }\end{array}$ & \multirow{3}{*}{ (UNSATURATED) (2) } \\
\hline \multirow{4}{*}{ MISSISSIPPIAN } & \multirow{2}{*}{ MERAMECIAN } & SALEM FORMATION (3) & $0-15$ & & $\begin{array}{l}\text { LINESTONE, LINEY DOLOMITE, FINELY TO COARSELY } \\
\text { CRYSTAL INE. MASSIVELY BEDDED. AND THIN BEDDED SHALE. }\end{array}$ & \\
\hline & & WARSAW FORMATION (3) & $60-80$ & & $\begin{array}{l}\text { SHALE ANO THIN TO MEDIUM BEDDED FINELY } \\
\text { CRYSTALLINE LINESTONE WITH INTERBEDOED CHERT. }\end{array}$ & \\
\hline & OSAGEAN & $\begin{array}{l}\text { FERN GLEN } \\
\text { LINESTONE }\end{array}$ & $45-70$ & $x+15$ & $\begin{array}{l}\text { CHERTY LIMESTONE, DOLOMITIC IN PART, YERY FINE TO } \\
\text { VEAY COARSELY CAYSTAL INE. MEOIUM TO THICKLY BEDDED. }\end{array}$ & SHALLOW AQUIFER SYSTEM \\
\hline & K INDERHDOK I AN & CHOUTEAU LIIESSTONE & $20-50$ & & $\begin{array}{l}\text { DOLOMITIC, ARG ILLACEOUS LINESTONEI FINELY } \\
\text { CRYSTALINE, THIN TO MEDIUM BEDOED. }\end{array}$ & \multirow{4}{*}{$\begin{array}{l}\text { UPPER LEAKY } \\
\text { CONF INING UNIT }\end{array}$} \\
\hline \multirow{2}{*}{ DEVDNIAN } & \multirow{2}{*}{ UPPER } & $\begin{array}{l}\text { SULPHUP SPR INGS GROUP(1) } \\
\text { BUSHBERO SAMOSTONE }\end{array}$ & \multirow{2}{*}{$40-55$} & & QUARTZ ARERNITE. FINE TO MEDIUM GRAINED. FRIABLE. & \\
\hline & & 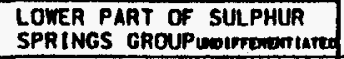 & & & $\begin{array}{l}\text { CALCAREOUS SILTSTONE, SANOSTONE, COLITIIC } \\
\text { LIMESTONE, ANO HARO CARBONACEOUS SHALE. }\end{array}$ & \\
\hline \multirow{10}{*}{ ORDOVICIAN } & CINCINNATIAN & MAOUOKETA SHALE (5) & $10-30$ & $=12=12$ & $\begin{array}{l}\text { CALCAREOUS TO DOLONITIC SILTY SHALE AND } \\
\text { MUDSTONE. THIMLY LAMINATED TO MASSIVE. }\end{array}$ & \\
\hline & \multirow{4}{*}{ CHAMPLAINIAN } & DECOAAH GROUP & $30-60$ & 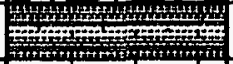 & $\begin{array}{l}\text { SHALE WITH THIN INTERBEDS OF VEAY } \\
\text { FINELY CRYSTAL INE LIMESTONE. }\end{array}$ & \multirow{3}{*}{$\begin{array}{l}\text { LOWER CONF INING } \\
\text { UNIT }\end{array}$} \\
\hline & & PLATTIN LIMESTONE & $100-130$ & (1/ & $\begin{array}{l}\text { DOLOMITIC LIMESTONE, VEAY FINELY CAYSTALL INE, } \\
\text { FOSSILIFEROUS, THIMLY BEODEO. }\end{array}$ & \\
\hline & & JOACHIM DOLOMITE & $80-105$ & $\frac{1}{2}$ & $\begin{array}{l}\text { INTERBEDDED VERY FINELY CRYSTALLINE, THINLY BEDDEOD } \\
\text { DOLOMITEI LINESTONE: AND SHALE. SANDY AT OASE. }\end{array}$ & \\
\hline & & ST. PETER SANOSTONE & $120-150$ & Mxtom & $\begin{array}{l}\text { OUARTZ ARENITE, FINE TO } \\
\text { MEDIUM GRAINED, MASSIVE. }\end{array}$ & \multirow{8}{*}{ DEEP AOUIFER SYSTEM } \\
\hline & \multirow{5}{*}{ CANADIAN } & POWELL DOLOMITE & $50-60$ & $x-2 x-2 x$ & $\begin{array}{l}\text { SANDY DOLOMITE, MEDIUM TO FINELY } \\
\text { CRYSTALINE. MINOA CHERT AND SHALE. }\end{array}$ & \\
\hline & & COTIEA DOLOMITE & $200-250$ & 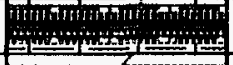 & $\begin{array}{l}\text { ARGILLACEOUS, CHERTY DOLOMITE FINE TO MED IUM } \\
\text { CRYSTALINE. INTERBEODED WITH SHALE. }\end{array}$ & \\
\hline & & JEFFERSON CITY DOT.OMITE & $160-180$ & $7=$ & DOLOMITE. FINE TO MEOIUM CRYSTAL INE. & \\
\hline & & ROUBIDOUX FORMATION & $150-170$ & $2+2+2+1+2$ & DOLOMITIC SAMDSTONE. & \\
\hline & & OASCONADE DOLOMITE & 250 & 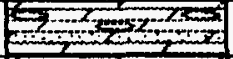 & $\begin{array}{l}\text { CHERTY DOLOMITE AND ARENACEOUS } \\
\text { DOLOMITE (GUNTER MEMOER). }\end{array}$ & \\
\hline \multirow{2}{*}{ CAMBRIAN } & \multirow{2}{*}{ UPPER } & EMINENCE DOLOMITE & 200 & 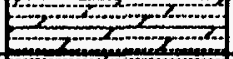 & $\begin{array}{l}\text { DDLOMITE, MEDIUM TO COAASELY CAYSTALL INE, } \\
\text { MEDIUM BEDDED TO MASSIVE. }\end{array}$ & \\
\hline & & POTOSI DOLOMITE & 100 & $z-z=2$ & $\begin{array}{l}\text { DOLOMITE, FINE TO MEDIUM CRYSTALLINE, THICKLY } \\
\text { BEDOED TO MASSIVE. ORUSY OUARTZ COMAON. }\end{array}$ & \\
\hline
\end{tabular}

(1) THICKNESS DATA SOURCES VARY OUATERMARY UNIT THICKNESS GASEO ON ON-SITE DRILLING

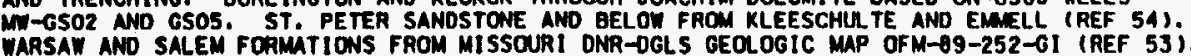

(2) GLACIAL DRIFT UNIT SATURATED IN MORTHERN PORTION OF ORONANCE WORKS WHERE THIS UNIT GEHAVES LOCALLY AS A LEAKY CONF INING UNIT. (GEOLOGIC LOG

GENERAL I ZED STRATIGRAPHY AND HYDROSTRATIGRAPHY OF THE WELDON SPRING AREA

(3) THE MAR5AN ANO SALEM FORMATIONS ARE CONSIDERED TO BE ABSENT FROM tHE wELOON SPRING AREA DUE TO EROSION.

(4) THE SULPHUR SPRINGS GROUP ALSO INCLUDES THE BACHELOR SANOSTONE AND THE GLEN PARK LIMESTONE-WTSSOURI DIVISION OF GEOLOG AND LAND SURVEY. (REF 53)

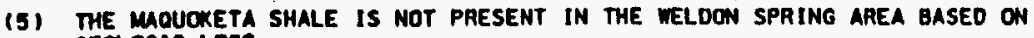
GEQOOGIC LOGS.

F I GURE 8-1

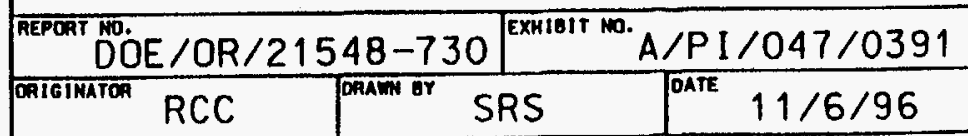


concentration guidelines (DCGs) for ingestion of water equivalent to 100 mrem (1.0 mSv) effective dose equivalent, based on the consumption of 730 liters/year (193 gal/year) (Table 8-2). As specified in Department of Energy Order 5400.5, liquid effluent from U.S. Department of Energy (DOE) activities may not cause private or public drinking waters to exceed the radiological limit of an effective dose equivalent greater than 4 mrem $(0.04 \mathrm{mSv} /$ year $)$ per year or $4 \%$ of the DCG.

Groundwater monitoring at the WSSRAP is a key component of the groundwater protection program. In addition to monitoring, the program integrates site-wide practices and policies in the interest of groundwater protection as specified by proposed Federal Code 10 CFR 834.

Upgradient-downgradient water quality comparisons are not practical for the chemical plant site because it sits atop a local groundwater high and straddles the regional groundwater divide (Ref. 37). Background values for uranium, nitrate, and sulfate were developed by the U.S. Geological Survey (USGS) for the shallow aquifer (Ref. 37) and are used in lieu of these comparisons.

\section{Table 8-1 Referenced Federal and State Water Standards}

\begin{tabular}{|c|c|c|c|c|c|c|c|}
\hline \multicolumn{2}{|c|}{ PARAMETER } & \multirow{2}{*}{$\begin{array}{l}\text { LEVEL } \\
20 \mu \mathrm{g} / 1 \\
(13.6 \mathrm{pCi} / \mathrm{l})\end{array}$} & \multirow{2}{*}{$\begin{array}{l}\text { REFERENCE } \\
\text { STANDARD } \\
\text { EPA }\end{array}$} & \multicolumn{2}{|c|}{ PARAMETER } & \multirow{2}{*}{$\frac{\text { LEVEL }}{300 \mu \mathrm{g} / 1}$} & \multirow{2}{*}{$\begin{array}{l}\text { REFERENCE } \\
\text { STANDARD } \\
\text { MDWS }\end{array}$} \\
\hline $\begin{array}{l}\text { Radio- } \\
\text { chemical }\end{array}$ & $\begin{array}{l}\text { Uranium } \\
\text { total }(a, c)\end{array}$ & & & \multirow[t]{9}{*}{ Metals } & $\mathrm{Fe}(\mathrm{d})$ & & \\
\hline & $\begin{array}{l}\text { Gross alpha } \\
\text { (adjusted) } \\
\text { (c) }\end{array}$ & $15 \mathrm{pCi} / 1$ & MDWS & & $\mathrm{Pb}(\mathrm{e})$ & $15 \mu g / 1$ & MDNR \\
\hline & $\operatorname{Ra}-226(b, c)$ & $5 \mathrm{pCi} / /$ & MDWS & & $M n(d)$ & $50 \mu g / 1$ & MDWS \\
\hline & $R n-222(a, c)$ & $300 \mathrm{pCi} / 1$ & EPA & & $\mathrm{Hg}(\mathrm{c})$ & $2.0 \mu \mathrm{g} / 1$ & MDWS \\
\hline \multirow[t]{2}{*}{ Misc. } & 2,4-DNT(e) & $0.11 \mu \mathrm{g} / \mathrm{l}$ & MDNR & & $\mathrm{Ni}(\mathrm{c})$ & $100 \mu \mathrm{g} / \mathrm{l}$ & MDWS \\
\hline & TDS(d) & $500 \mathrm{mg} / \mathrm{l}$ & MDWS & & $\mathrm{Se}(\mathrm{c})$ & $50 \mu \mathrm{g} / 1$ & MDWS \\
\hline \multirow[t]{7}{*}{ Metals } & $\mathrm{Sb}(\mathrm{c})$ & $6.0 \mu \mathrm{g} / \mathrm{I}$ & MDWS & & $\mathrm{Ag}(\mathrm{d})$ & $100 \mu \mathrm{g} / \mathrm{l}$ & MDWS \\
\hline & $\mathrm{As}(\mathrm{c})$ & $50 \mu \mathrm{g} / 1$ & MDWS & & $Z n(d)$ & $5.0 \mathrm{mg} / \mathrm{l}$ & MDWS \\
\hline & $\mathrm{Ba}(\mathrm{c})$ & $2 \mathrm{mg} / \mathrm{l}$ & MDWS & & & & \\
\hline & $\mathrm{Be}(\mathrm{c})$ & $4.0 \mu \mathrm{g} / 1$ & MDWS & \multirow[t]{4}{*}{ Anions } & $\mathrm{Cl}$ (d) & $250 \mathrm{mg} / \mathrm{l}$ & MDWS \\
\hline & $\operatorname{cd}(c)$ & $5 \mu \mathrm{g} / 1$ & MDWS & & $F-(d)$ & $2.0 \mathrm{mg} / \mathrm{I}$ & MDWS \\
\hline & $\mathrm{Cr}(\mathrm{c})$ & $100 \mu \mathrm{g} / 1$ & MDWS & & NO3(c) & $10 \mathrm{mg} / \mathrm{l}$ & MDWS \\
\hline & $\mathrm{Cu}(\mathrm{d})$ & $1.0 \mathrm{mg} / \mathrm{l}$ & MDWS & & $\mathrm{SO4(d)}$ & $250 \mathrm{mg} / \mathrm{l}$ & MDWS \\
\hline
\end{tabular}

(a) Proposed.

(b) Standard for combined Ra-226 and Ra-228.

(c) Primary maximum contaminant level.

(d) Secondary maximum contaminant level.

(e) Water Quality Standard for Groundwater.

EPA EPA Drinking Water Standards for Radionuclides.

MDNR Missouri Department of Natural Resources

MDWS Missouri Drinking Water Standard. 
Table 8-2 Derived Concentration Guidelines for Discharge Waters

\begin{tabular}{|l|l|}
\hline PARAMETER & DERIVED CONCENTRATION GUIDELINE \\
\hline Natural Uranium & $600 \mathrm{pCi} / \mathrm{I}$ \\
\hline Ra-226 & $100 \mathrm{pCi} / 1$ \\
\hline Ra-228 & $100 \mathrm{pCi} / 1$ \\
\hline Th-230 & $300 \mathrm{pCi} / /$ \\
\hline Th-232 & $50 \mathrm{pCi} / 1$ \\
\hline
\end{tabular}

Note: $1 \mathrm{pCi} / \mathrm{l}=0.037 \mathrm{~Bq} / \mathrm{l}$.

\subsection{Weldon Spring Chemical Plant}

\subsubsection{Hydrogeologic Description}

The Weldon Spring Chemical Plant is located in a physiographic transitional area between the Dissected Till Plains of the central lowlands province to the north and the Salem Plateau of the Ozark Plateaus province to the south.

The chemical plant is located on a groundwater divide from which groundwater flows north toward Dardenne Creek and then ultimately to the Mississippi River, or south to the Missouri River. Regional groundwater flow for St. Charles County is towards the east. Localized flow is controlled largely by topographic highs and streams and drainages. Groundwater movement is generally by diffuse flow with localized zones of discrete fracturecontrolled flow.

The chemical plant and raffinate pit area lithologies consist of two major geologic units; unconsolidated surficial material and carbonate bedrock. The unconsolidated surficial materials are clay-rich, mostly glacially derived units, which are generally unsaturated. Thicknesses range

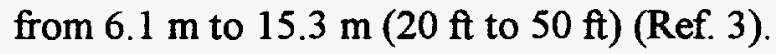

Potential groundwater impacts are assessed by monitoring groundwater from the monitoring well network at the site. The aquifer of concern beneath the chemical plant, raffinate pits, and vicinity properties is the shallow bedrock aquifer comprised of Mississippian-age Burlington-Keokuk Limestone (the uppermost bedrock unit) and the Fern Glen Limestone. The Burlington-Keokuk Limestone is composed of two different lithologic zones, a shallow weathered zone underlain by an unweathered zone. The weathered portion of this formation is highly fractured and exhibits solution voids and enlarged fractures. These features may also be found on a limited scale in the unweathered zone. The unweathered portion of the Burlington-Keokuk Limestone is thinly to massively bedded. Fracture densities are significantly less in the unweathered zone than in the weathered zone. Localized aquifer properties are controlled by fracture spacing, solution voids, and preglacial weathering, including structural troughs along the bedrock-unconsolidated material interface. 
All monitoring wells are completed in the Burlington-Keokuk Limestone. Of the 64 monitoring wells, 18 are completed (screened) in the unweathered zone. The wells in the unweathered zone of the Burlington-Keokuk Limestone are used to assess the vertical migration of contaminants. The remainder of the wells are open to the weathered unit of the bedrock where groundwater has the greatest potential for contaminant impact. Where possible, monitoring wells within the boundaries of the chemical plant are located close to potential contaminant sources to assess migration into the groundwater system. Additional wells are located outside the chemical plant boundary to detect and evaluate potential off-site migration of contaminants (Figure 8-2).

Springs, a common feature in carbonate terrains, are present in the vicinity of the Weldon Spring site. Four springs are known to have been historically influenced by chemical plant discharge water potentially containing one or more of the contaminants of concern (Figure 8-3). Currently, Burgermeister Spring (SP-6301 on Figure 8-3) is monitored to determine contaminant off-site migration potential via spring transport.

The presence of elevated total uranium and nitrate levels at Burgermeister Spring, which is located $1.9 \mathrm{~km}(1.2 \mathrm{mi})$ north of the site, indicates that discrete flow paths are present in the vicinity of the site.

\subsubsection{Monitoring Program}

\subsubsection{Purpose}

The 1997 groundwater monitoring program at the chemical plant and raffinate pits focused on monitoring known contaminants and determining any groundwater impacts which may result from remedial action at the site. Total uranium, nitroaromatic compounds, sulfate, volatile organic compounds, and nitrate were monitored annually at selected locations. Total uranium in groundwater was analyzed under the environmental monitoring program at the chemical plant to monitor potential groundwater uranium plume migration and to further establish baseline uranium concentrations prior to source removal during remedial action. Due to the heterogeneity of uranium distribution in soils across the site, all active locations in the chemical plant groundwater monitoring network were analyzed for total uranium.

Groundwater in the vicinity of the raffinate pits is impacted with elevated nitrate concentrations. The pits contain ore-refining impurities from uranium ore concentrates that were digested with nitric acid. Some of the wastes generated and disposed of as raffinate contained isotopes of thorium and radium. Therefore, groundwater samples from selected locations near the raffinate pits have historically been analyzed for nitrate, thorium, and radium isotopes, and total uranium. An enhanced monitoring program was initiated during 1997 designed to detect any groundwater contaminant impact resulting from raffinate pit remediation efforts. The enhanced 


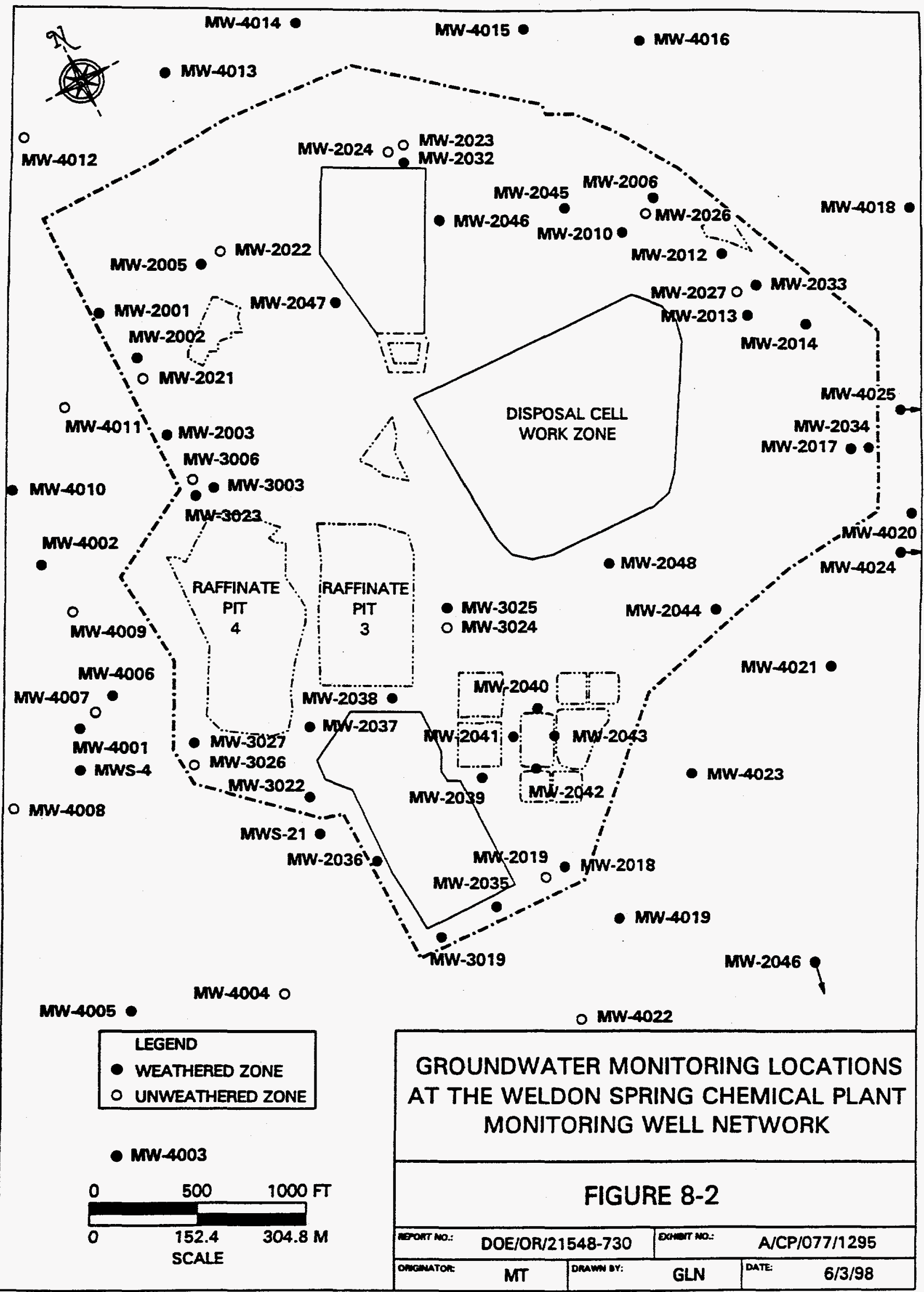




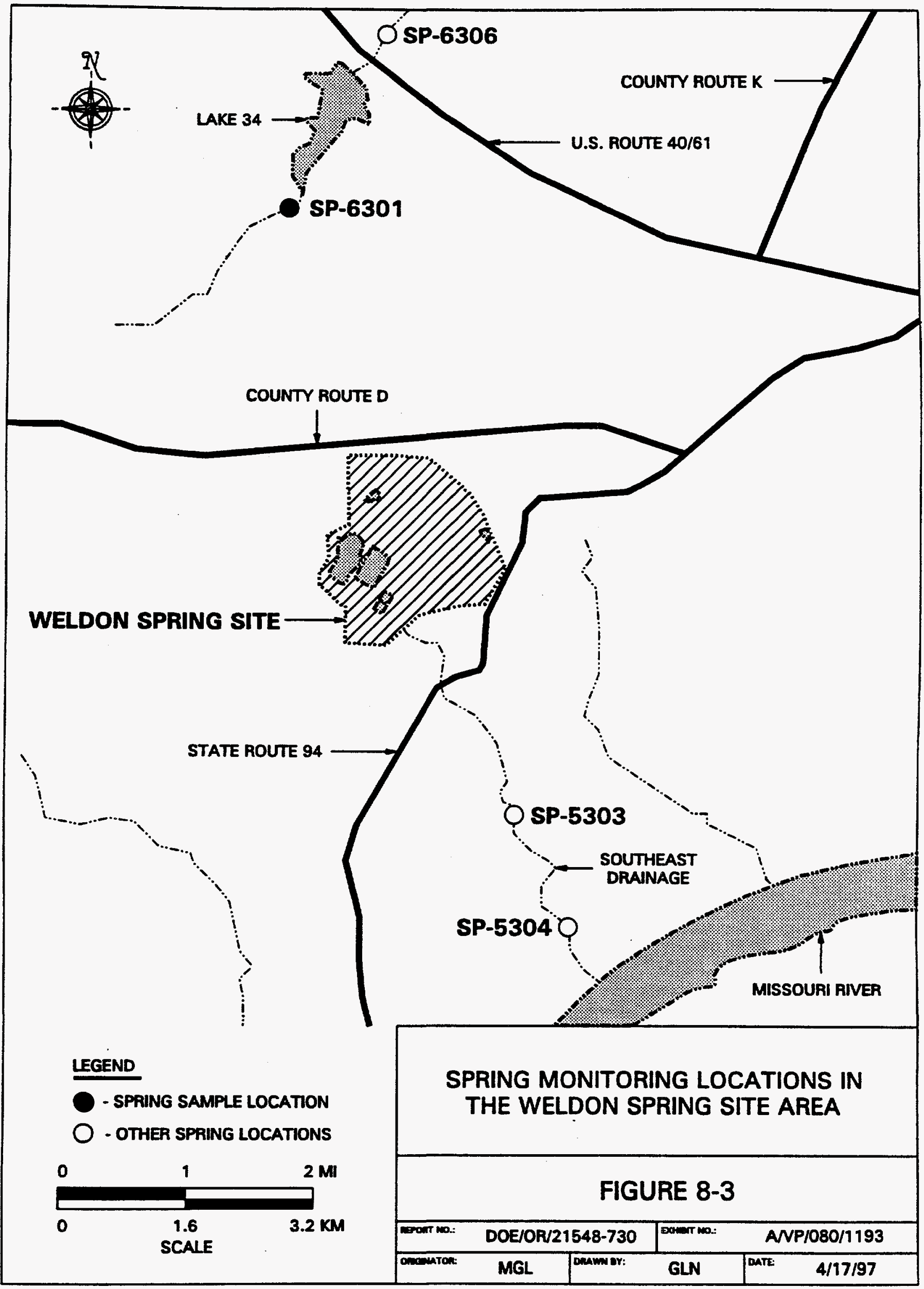


program included monthly monitoring for nitrate, sulfate, metals, and radiological parameters at 11 locations in the vicinity of the raffinate pits.

Prior to construction of the chemical plant, the site was part of a Department of Army Ordnance Works complex developed for the production of the nitroaromatic compounds TNT and DNT for explosives. One of the first nitroaromatic production lines was located within what is now the chemical plant area perimeter. Wastes generated from the initial operation of these early production lines were disposed of in open earthen pits which released contaminated seepage to groundwater. Wastewater containing nitroaromatic compounds was transported through wooden pipe networks. Discrete locations at the chemical plant are known (from previous sampling) to be impacted with nitroaromatics. Those locations, which were previously determined to have detectable concentrations of nitroaromatics in groundwater, were sampled and analyzed for these compounds in 1997.

The VOC trichloroethene (TCE) was detected in groundwater south and east of Raffinate Pits 3 and 4 during 1996. VOC monitoring was conducted during 1997 to determine lateral and vertical extents of the TCE and to assess the mobility of the contaminant.

Groundwater moves by both diffuse and discrete flow components under the chemical plant. In order to monitor the discrete flow component, Burgermeister Spring was monitored during 1997 for total uranium, nitroaromatic compounds, volatile organic compounds, nitrate, sulfate, and geochemical parameters. The spring was sampled during high- and base-flow conditions to monitor the potential impacts to the spring recharge from surface water runoff in the vicinity of the chemical plant.

\subsubsection{Scope}

All monitoring wells (except those completed in the unweathered zone) were sampled annually and analyzed for total uranium. Monitoring wells around the raffinate pits and chemical plant buildings were also analyzed annually for Ra-226, Ra-228, Th-228, Th-230, Th-232, and nitrate. Nitroaromatics were analyzed in groundwater from locations that have historically shown detectable concentrations of these compounds. A summary of monitoring locations and analytes may be found in the 1997 Environmental Monitoring Plan (EMP) (Ref. 42).

The EMP includes provisions for initiation of special environmental studies if evidence or conditions arise that warrant investigation beyond the scope of the EMP sampling schedule. A special, or unscheduled, groundwater sampling event was initiated in response to disturbance of soils and sludges during remediation of Raffinate Pits 1, 2, and 4.

Burgermeister Spring (SP-6301) was monitored quarterly for metals, nitrate, sulfate, and geochemical constituents. Volatile organic compounds were monitored monthly to biweekly. 
The spring was monitored at low flow to measure the groundwater component of spring discharge. It was sampled twice at high flow for uranium, nitrate, and sulfate to evaluate the differences between low flow and high flow.

\subsubsection{Chemical Plant and Raffinate Pit Monitoring Results}

\subsubsection{Groundwater Monitoring Wells}

In 1997, the measured concentrations for uranium, nitrate, sulfate, and nitroaromatic compounds generally remained within historical ranges at all monitoring wells and springs in the chemical plant area. Volatile organic compounds which were first detected during 1996 in groundwater in the vicinity of the raffinate pits were monitored during 1997.

Data for all parameters analyzed during the 1997 monitoring period are presented in the Quarterly Environmental Data Summaries. The monitoring data for contaminants of concern (uranium, radiological parameters, nitrate, sulfate, volatile organic compounds and nitroaromatics) are summarized and compared with background levels and water quality standards in the following paragraphs. Data values are presented as reported by the analytical laboratories. Comparisons to drinking water standards are not intended to imply that groundwater from WSSRAP monitoring wells must be in compliance with drinking water standards.

Radiochemical Parameters. Total uranium, which is measured at all monitoring wells, continues to impact groundwater near the raffinate pits. In 1997, groundwater from 12 monitoring well locations exceeded the average background level of $2.9 \mathrm{pCi} / 1(0.11 \mathrm{~Bq} / \mathrm{l})$ as calculated by the USGS (Ref. 37). These values can be found in Table 8-3. Of these, only three locations exceeded or equaled the proposed MCL of $20 \mu \mathrm{g} / 1(13.6 \mathrm{pCi} / \mathrm{l})$. A new high for uranium was recorded during 1997 at MW-3024 (52.4 pCi/l). Monitoring well MW-3024 was damaged in early 1997 and restoration of this well included drilling out the casing and screen to facilitate installation of new well construction materials. Elevated uranium values above the MCL standard were first detected in this location following the well repair completion.

Table 8-3 Annual Total Uranium Activities (pCi/l) Above Background at the Weldon Spring Chemical Plant

\begin{tabular}{|c|c|c|c|c|c|}
\hline LOCATION & $\begin{array}{l}\text { AVERAGE } \\
(\mathrm{pCi} / /)\end{array}$ & LOCATION & $\begin{array}{l}\text { AVERAGE } \\
\text { (pCi/l) }\end{array}$ & LOCATION & $\begin{array}{l}\text { AVERAGE } \\
(\mathrm{pCi} / \mathrm{l})\end{array}$ \\
\hline MW-2017 & 9.41 & $\mathrm{MW}-2032$ & 4.09 & MW-4021 & 3.14 \\
\hline MW-3003 & 15.9 & $M W-3023$ & 12.9 & $M W-4010$ & 12.2 \\
\hline $\mathrm{MW}-4005$ & 5.83 & $M W-3024$ & 52.4 & $M W-4022$ & 4.36 \\
\hline MW-4020 & 13.9 & $M W-3025$ & 3.56 & $M W-4024$ & 6.94 \\
\hline
\end{tabular}

Note 1: Background uranium concentration equals $2.9 \mathrm{pCill}$.

Note 2: $1 \mathrm{pCi} / \mathrm{l}=0.037 \mathrm{~Bq} / \mathrm{l}$.

The other radiological parameters (Ra-226, Ra-228, isotopic thorium, gross alpha, and gross beta) that are measured annually in the raffinate pit wells (MW-3000 series and MW-2044) 
were below the MCL values. These annual averages can be found in Table 8-4. Total uranium trends are discussed in Section 8.4.4.

Table 8-4 Annual Radiological Isotope Activities (pCi//) at the Weldon Spring Chemical Plant

\begin{tabular}{|c|c|c|c|c|c|c|}
\hline LOCATION & $\begin{array}{l}\text { RA-226 } \\
(\mathrm{pCi} / 1)\end{array}$ & $\begin{array}{l}\text { RA-228 } \\
\text { (pCi/l) }\end{array}$ & $\begin{array}{l}\text { TH-230 } \\
\text { (pCi/l) }\end{array}$ & $\begin{array}{l}\text { TH-232 } \\
\text { (pCi/l) }\end{array}$ & $\begin{array}{l}\text { GROSS } \\
\text { ALPHA } \\
\text { (pCi/l) }\end{array}$ & $\begin{array}{l}\text { GROSS } \\
\text { BETA } \\
\text { (pCi/l) }\end{array}$ \\
\hline MW-2035 & 2.20 & $<0.40$ & $<0.22$ & $<0.50$ & NA & NA \\
\hline MW-2036 & 0.70 & $<0.40$ & $<0.34$ & $<0.24$ & NA & NA \\
\hline MW-2037 & $<0.06$ & 2.52 & 0.44 & $<0.06$ & NA & $\overline{\mathrm{NA}}$ \\
\hline$M W-2038$ & 0.51 & $(0.08)$ & 0.21 & 0.03 & NA & NA \\
\hline MW-2039 & $<0.4$ & $(0.3)$ & $<0.69$ & $(0.28)$ & NA & NA \\
\hline MW-2040 & 0.60 & 0.10 & $<0.28$ & 1.80 & NA & NA \\
\hline MW-2041 & 2.00 & 0.50 & $<0.49$ & $<0.49$ & NA & NA \\
\hline MW-2042 & 2.80 & $<0.40$ & $<1.00$ & $<0.70$ & NA & NA \\
\hline MW-2043 & 0.90 & $<0.40$ & $(0.24)$ & $(0.24)$ & NA & NA \\
\hline MW-2044 & $(0.18)$ & 2.76 & $(0.01)$ & $<0.01$ & 23.2 & 11.8 \\
\hline MW-3003 & 0.40 & $(0.26)$ & 0.08 & 0.05 & 25.6 & 31.0 \\
\hline MW-3019 & 1.25 & $<0.52$ & 0.29 & 0.05 & 2.43 & 2.01 \\
\hline MW-3023 & 0.28 & $(0.23)$ & 0.15 & 0.08 & 0.87 & 1.49 \\
\hline MW-3024 & $(0.23)$ & 1.50 & 0.15 & $(0.06)$ & 46.3 & 20.3 \\
\hline$M W-3025$ & 0.70 & $(0.15)$ & $(0.07)$ & 0.08 & 12.7 & 40.9 \\
\hline$M W-3026$ & 0.60 & 2.68 & 0.51 & 0.72 & 30.5 & 24.9 \\
\hline$M W-3027$ & 0.88 & 1.57 & 0.50 & 0.34 & 2.66 & 0.86 \\
\hline
\end{tabular}

Note 1: Values in parentheses are estimates below quantification limits.

NA Not Analyzed.

Nitrate and Sulfate. In 1997, nitrate and sulfate were measured at 20 monitoring wells in the chemical plant area that previously exceeded the reference levels. Nitrate levels exceeded the drinking water standard $(10 \mathrm{mg} / \mathrm{l})$ at all of those locations (Table 8-5). Average sulfate levels exceeded background (32 $\mathrm{mg} / \mathrm{l})$ at 18 locations; one of these (MW-2017) was above the secondary water quality standard (250 $\mathrm{mg} / \mathrm{l}$ ) (Table 8-6).

The 1997 nitrate data indicate no increases in nitrate levels for all monitored locations north of Raffinate Pits 3 and 4 with the exceptions of MW-2001, MW-2005, and MW-2032. Four locations south and west of the raffinate pits (MW-2037, MW-2039, MW-3027, and MW-4006) increased in nitrate average concentrations during 1997. These increases are likely due to soil disturbances during remediation of Raffinate Pit 2 and Pit 4 . Nitrate and sulfate are included in the raffinate pit area enhanced monitoring program which will continue through 1998. Trend analyses for nitrate and sulfate are discussed in Section 8.4.4. 
Table 8-5 Annual Values of Nitrate $(\mathrm{mg} / \mathrm{l})$ Levels Exceeding Drinking Water Quality Standard at the Weldon Spring Chemical Plant

\begin{tabular}{|l|l|l|l|l|l|}
\hline LOCATION & AVERAGE & LOCATION & AVERAGE & LOCATION & AVERAGE \\
\hline MW-2001 & 68.4 & MW-2002 & 46.0 & $M W-2003$ & 288 \\
\hline$M W-2005$ & 83.0 & $M W-2032$ & 64.9 & $M W-2037$ & 289 \\
\hline$M W-2038$ & 798 & $M W-2039$ & 57.1 & $M W-2040$ & 155 \\
\hline$M W-2041$ & 154 & $M W-4001$ & 44.1 & $M W-3025$ & 454 \\
\hline$M W-3003$ & 365 & $M W-3023$ & 164 & $M W-3024$ & 391 \\
\hline$M W-3026$ & 167 & $M W-3027$ & 104 & $M W-4011$ & 173 \\
\hline$M W-4006$ & 21.4 & & & $M W-2048$ & 79.0 \\
\hline
\end{tabular}

Note 1: Drinking water quality standard equals $10 \mathrm{mg} / \mathrm{l}$

Table 8-6 Annual Values of Sulfate $(\mathrm{mg} / \mathrm{l})$ Above Background at the Weldon Spring Chemical Plant

\begin{tabular}{|l|l|l|l|l|l|}
\hline LOCATION & AVERAGE & LOCATION & AVERAGE & LOCATION & AVERAGE \\
\hline MW-2032 & 46.2 & MW-3003 & 180 & MW-3023 & 186 \\
\hline MW-3024 & 68.0 & MW-3025 & 46.3 & MW-4001 & 55.0 \\
\hline MW-2017* & 735 & MW-2037 & 123 & MW-2038 & 81.2 \\
\hline MW-2039 & 32.1 & MW-2041 & 37.4 & MW-2042 & 32.4 \\
\hline MW-4011 & 80.6 & MW-2045 & 38.9 & MW-2046 & 54.2 \\
\hline MW-4026 & 35.6 & MW-2047 & 35.9 & MW-2048 & 172 \\
\hline
\end{tabular}

Note 1: Background sulfate concentration equals $32 \mathrm{mg} / 1$

- Exceeded the sulfate secondary drinking water quality standard of $250 \mathrm{mg} / \mathrm{l}$ at least once during 1995.

Groundwater trending for nitrate was performed for selected locations for 1997 . The groundwater results are not trended annually for the chemical plant because, at most monitoring locations, sampling frequency has been decreased (annual) to a level that cannot justify frequent trending. The biannual trending results are presented in Section 8.4.4.

Sulfate analytical results show no significant $(>5 \%)$ increases at any of the monitored locations during 1997, with the exception of MW-3003 and MW-3023. These monitoring wells are located along the northern perimeter of Raffinate Pit 4 . The increases are believed to be related to Raffinate Pit 4 remediation and the locations will be carefully monitored to identify any increasing trends.

Nitroaromatic Compounds. Nitroaromatic compounds, which are not naturally occurring compounds, were detected in 27 monitoring wells (Table 8-7). No new highs were recorded during 1997 and with the exception at MW-2012, values were within the normal range of variation for all locations. The increases at MW-2012 were significant with concentrations of 2,4-DNT and 2,6-DNT increased from $0.08 \mu \mathrm{g} / 1$ to $6.0 \mu \mathrm{g} / 1$ and $6.3 \mu \mathrm{g} / 1$ to $110 \mu \mathrm{g} / \mathrm{l}$, respectively. Levels of TNT increased from an average of $0.44 \mu \mathrm{g} / \mathrm{l}$ in 1996 to $23 \mu \mathrm{g} / \mathrm{l}$ in 1997.

The drinking water standard for $2,4-\mathrm{DNT}$ of $0.11 \mu \mathrm{g} / 1$ was equaled or exceeded in 13 locations at the chemical plant (see Table 8-7), all of which are in the northern one-third of the site or along the western perimeter. Elevated nitroaromatics in groundwater underlying the 
northern portion of the site are most likely attributable to a wastewater impoundment which was located along the northern site perimeter during the early active production of TNT and DNT during the 1940's.

Table 8-7 Annual 1997 Averages for Monitoring Locations with at Least One Detectable Concentration of Nitroaromatic Compounds $(\mu \mathrm{g} / \mathrm{l})$ at the Weldon Spring Chemical Plant

\begin{tabular}{|c|c|c|c|c|c|c|}
\hline LOCATION & $1,3,5-\mathrm{TNB}$ & 1,3-DNB & $2,4,6-T N T$ & 2,4-DNT & 2,6 -DNT & NB \\
\hline MW-2001 & 0.060 & $<0.090$ & $<0.030$ & 0.083 & 0.054 & $<0.030$ \\
\hline MW-2002 & $<0.030$ & $<0.090$ & $<0.030$ & $(0.024)$ & 0.090 & $<0.030$ \\
\hline MW-2003 & $<0.030$ & $<0.090$ & $<0.030$ & 0.120 & 0.430 & $<0.030$ \\
\hline MW-2005 & 0.058 & $(0.047)$ & $<0.030$ & 0.048 & 0.086 & $<0.030$ \\
\hline MW-2006 & 7.00 & $(0.067)$ & $<0.030$ & 0.13 & 1.20 & 0.054 \\
\hline MW-2010 & 0.120 & $(0.049)$ & 0.13 & 0.088 & 0.66 & $<0.030$ \\
\hline$M W-2012$ & 4.00 & $<0.090$ & 23.0 & 6.0 & 110 & $<0.030$ \\
\hline MW-2013 & 4.2 & $(0.045)$ & 0.88 & 0.17 & 2.10 & $<0.030$ \\
\hline MW-2014 & 2.7 & $(0.082)$ & $<0.030$ & 0.160 & 0.49 & $<0.030$ \\
\hline MW-2032 & 1.19 & $(0.05)$ & 2.65 & 0.08 & 0.75 & $<0.030$ \\
\hline$M W-2033$ & 5.3 & $<0.090$ & 1.4 & 0.12 & 1.50 & $<0.030$ \\
\hline MW-2037 & 0.17 & $(0.08)$ & $<0.030$ & 0.59 & 0.12 & $<0.060$ \\
\hline MW-2038 & 0.17 & $(0.06)$ & $<0.030$ & 1.30 & 0.24 & 0.04 \\
\hline MW-2043 & $<0.030$ & $<0.090$ & $<0.030$ & 0.08 & $<0.010$ & $<0.030$ \\
\hline MW-2045 & $<0.030$ & 0.117 & $<0.030$ & 0.116 & 0.547 & $<0.030$ \\
\hline MW-2046 & 1.761 & 0.131 & 1.72 & 0.400 & 23.29 & $<0.030$ \\
\hline$M W-2047$ & $<0.030$ & $<0.090$ & $<0.030$ & 0.280 & 0.660 & $<0.030$ \\
\hline MW-3003 & $<0.030$ & $<0.090$ & $<0.030$ & 0.097 & 0.16 & $<0.040$ \\
\hline$M W-3023$ & $<0.030$ & $<0.090$ & $<0.060$ & 0.73 & 2.40 & $<0.040$ \\
\hline $\mathrm{MW}-3025$ & $<0.030$ & $<0.090$ & $<0.030$ & 0.099 & 0.27 & $<0.040$ \\
\hline$M W-3026$ & 0.074 & $<0.090$ & $<0.030$ & 0.041 & 0.019 & $<0.040$ \\
\hline$M W-3027$ & 0.076 & $<0.090$ & $<0.030$ & 0.033 & 0.031 & $<0.040$ \\
\hline$M W-4001$ & 62.0 & $<0.090$ & 2.20 & 0.13 & 2.50 & $<0.06$ \\
\hline$M W-4002$ & $<0.030$ & $<0.090$ & 0.049 & $<0.030$ & 0.040 & $<0.040$ \\
\hline MW-4006 & 21 & $<0.090$ & $<0.030$ & 0.078 & 2.30 & $<0.040$ \\
\hline MW-4011 & $<0.030$ & $<0.090$ & $<0.030$ & $<0.030$ & 0.040 & $<0.040$ \\
\hline$M W-4015$ & 5.60 & $<0.090$ & $<0.030$ & 0.070 & 0.82 & $<0.030$ \\
\hline
\end{tabular}

The trend analysis performed using 1995-1997 data are discussed in Section 8.4.4.

Volatile Organic Compounds. The VOC groundwater investigation was initiated during 1996 when dewatering activities in Raffinate Pit 4 exposed approximately 2,000 previouslysubmerged drums of waste. Whether the wastes from the drums impacted groundwater remains uncertain. The uncertainty is due to the small quantity of pre-1996 groundwater data for VOCs from monitoring wells in the vicinity of Raffinate Pits 3 and 4. The TCE investigation continued through 1997 in order to further define the extent of contamination. The 1997 analytical results are summarized in Table 8-8. 
Table 8-8 1997 TCE and DCE Analytical Results Summary

\begin{tabular}{|c|c|c|c|c|c|c|c|c|c|c|c|c|c|}
\hline DATE & & $\operatorname{Jan} 97$ & Feb 97 & Mar 97 & Apr 97 & May 97 & Jun 97 & Jul 97 & Aug 97 & Sep 97 & Oct 97 & Nov 97 & Dec 97 \\
\hline \multirow[t]{2}{*}{$\mathrm{MW}-2013$} & TCE & ND & $2^{*}$ & N.S & ND & $1^{*}$ & 9 & $1.13(1)$ & $1.27(1)$ & $1.06(1)$ & N.S & $1.16(1)$ & ND \\
\hline & $\overline{D C E}$ & 15 & $7^{*}$ & N.S & $3^{*}$ & $4^{*}$ & $8^{*}$ & $8^{*}$ & $8^{\star}$ & $9^{*}$ & N.S. & $6^{*}$ & $6^{*}$ \\
\hline \multirow[t]{2}{*}{ MW-2032 } & TCE & $\mathrm{ND}$ & $1^{*}$ & N.S & $1.2^{\star}$ & $1^{*}$ & $1.2(1)$ & $1.63(1)$ & $\mathrm{ND}$ & ND & ND & ND & ND \\
\hline & $\overline{D C E}$ & $\mathrm{ND}$ & $1^{*}$ & N.S & $3.2^{\star}$ & $1^{*}$ & $2^{*}$ & $2^{*}$ & ND & ND & ND & ND & ND \\
\hline \multirow[t]{2}{*}{ MW-2037 } & TCE & 1300 & 1300 & 1100 & 1200 & 1200 & 1300 & 1200 & 1200 & 1100 & 960 & 950 & 1200 \\
\hline & DCE & 12 & 12 & 14 & 15 & 15 & 21 & 24 & 29 & 25 & 21 & 25 & 20 \\
\hline \multirow[t]{2}{*}{ MW-2038 } & TCE & 790 & 860 & 680 & 710 & 640 & 620 & 620 & 560 & 530 & 370 & 350 & 360 \\
\hline & DCE & 26 & 13 & 12 & 13 & 15 & 19 & 19 & 20 & 10 & 13 & 12 & 13 \\
\hline \multirow[t]{2}{*}{$\mathrm{MW}-2046$} & TCE & N.S & ND & N.S. & $0.62^{\star}$ & N.S & N.S & ND & N.S & N.S & ND & N.S & N.S \\
\hline & $\overline{D C E}$ & N.S & $2^{*}$ & N.S. & $2.7^{*}$ & N.S & N.S & $3^{*}$ & N.S & N.S & $3^{*}$ & N.S & N.S \\
\hline \multirow[t]{2}{*}{$\mathrm{MW}-3024$} & TCE & ND & ND & N.S. & ND & ND & ND & ND & $\mathrm{ND}$ & $\mathrm{ND}$ & ND & $\mathrm{ND}$ & ND \\
\hline & $\overline{D C E}$ & ND & ND & N.S. & ND & ND & ND & ND & ND & ND & ND & ND & ND \\
\hline \multirow[t]{2}{*}{ MW-3025 } & TCE & 38 & 40 & N.S. & 50 & 26 & $\overline{N D}$ & 30 & 35 & 32 & 29 & 28 & 27 \\
\hline & DCE & ND & ND & N.S. & ND & ND & ND & ND & ND & $2^{*}$ & ND & ND & ND \\
\hline \multirow[t]{2}{*}{$\mathrm{MW}-4001$} & TCE & ND & N.S. & N.S. & $4^{*}$ & 2.68 & $5.49(1)$ & $4.64(1)$ & $4.32(1)$ & $4.78(1)$ & $4(1)$ & $4.78(1)$ & $4(1)$ \\
\hline & DCE & $\mathrm{ND}$ & N.S. & N.S. & $\overline{N D}$ & ND & ND & $\mathrm{ND}$ & $\mathrm{ND}$ & $\mathrm{ND}$ & $\overline{N D}$ & $\overline{N D}$ & $\mathrm{ND}$ \\
\hline MW-S021 & TCE & N.S. & 643 & 800 & 780 & 770 & 630 & 620 & 420 & 540 & 470 & 430 & 460 \\
\hline & $\overline{D C E}$ & N.S & 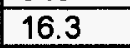 & & & & 12 & & & & $8^{*}$ & & \\
\hline
\end{tabular}

(1) GC Method

* Below method detection limit, estimated value

N.S. Not sampled 
VOCs were detected at seven locations in groundwater at the chemical plant and the Weldon Spring Training Area (WSTA) during 1996. The chlorinated solvent compounds TCE and 1,2-DCE, which do not naturally occur, were reported above detection limits as primarily TCE east and south of Raffinate Pits 3 and 4 (MW-2037 MW-2038, MW-3025, and S021); and DCE south of the former Frog Pond location (MW-2013). VOCs below quantification limits were reported at two monitoring locations, MW-2032 (west-northwest of Frog Pond) and MW-4001 (west of Raffinate Pit 4).

Groundwater sampling for VOC analysis at the above-listed locations continued during 1997. The VOC sampling program was initiated to determine the lateral and vertical extents of VOC contamination, and to assess mobility of the contaminant. The lateral extents of TCE were approximately identified to be bounded to the north by the north perimeter of Raffinate Pits 3 and 4, to the south by Army Property monitoring well MW-S04, to the east by Raffinate Pits 1 and 2, and to the west by monitoring well MW-4001. The vertical extent of the TCE is limited to the weathered bedrock of the Burlington-Keokuk with no TCE detection in the unweathered zone.

The source of the VOCs remained unknown as the investigation continued throughout 1997. It is suspected that these solvent components are trapped in pockets of sludge which isolate the VOCs from volatilization or microbial degradation and have migrated to groundwater via discrete fracture flow. Due to the limited areal extent of groundwater impact, it is possible that the VOC introduction to groundwater is a recent event that may be a response to remedial action in Raffinate Pit 4 or sludge dredging in Raffinate Pit 3. The investigation is expected to continue throughout 1998 and groundwater remedial action is being considered.

Metals. Eleven locations were monitored monthly for metals for the enhanced groundwater monitoring in the vicinity of the raffinate pits. The 1997 data from these locations were compared to historical metals data to assess groundwater impacts resulting from raffinate pit remediation. No elevated metals were detected during 1997 for this enhanced monitoring program.

Groundwater Overview. With few exceptions, contaminant levels remained within historical ranges at the monitoring wells sampled under the environmental monitoring program. Because contaminant levels have displayed only minor variability over the historical monitoring period, trend analysis is not conducted annually for the chemical plant monitoring wells. Select 1997 chemical plant locations were trended and are discussed in Section 8.4.4. Uranium, sulfate, and nitrate contamination continue to be concentrated in the area surrounding the raffinate pits with a small area of elevated uranium and sulfate located near the eastern boundary of the site. Pockets of nitroaromatic contaminated groundwater continue to be present in the vicinity of Frog Pond, along the northern perimeter of the site, near Raffinate Pit 4, and west of the raffinate pits on the Weldon Spring Ordnance Works property. The source of VOC contamination south and east of Raffinate Pit 3 remains under investigation. The enhanced groundwater monitoring in the 
raffinate pits vicinity suggested no significant impact to groundwater quality attributable to raffinate pit remediation has occurred.

\subsubsection{Springs}

Springs located in Valley 6300 and Valley 5300 were monitored for the 1997 environmental monitoring program. Burgermeister Spring (SP-6301) is a perennial spring and is a localized emergence of groundwater impacted by a recognizable contribution of contaminants from the chemical plant throughout the year, with the highest concentrations of contaminants occurring during base flow stages. During high flow conditions, surface water recharge along the path of the subsurface flow mixes with contaminated flow from the site, and the concentrations are effectively lowered. The spring was monitored during both high and base stages during 1997.

Burgermeister Spring samples for uranium, nitrate, and nitroaromatics were within expected (historical) ranges during 1997. The mean concentrations for nitrate and sulfate during base flow are $16.5 \mathrm{mg} / \mathrm{l}$ and $45.6 \mathrm{mg} / \mathrm{l}$, respectively. These concentrations for high stage flow are $1.2 \mathrm{mg} / \mathrm{l}$ and $30.0 \mathrm{mg} / \mathrm{l}$, respectively. These results indicate that groundwater is a more significant contributor to the spring discharge during base flow. The concentrations for these parameters are lower during high flow due to surface water contribution. Base flow concentrations for nitrate ranged between $4.54 \mathrm{mg} / \mathrm{l}$ and $36 \mathrm{mg} / \mathrm{l}$. Base flow sulfate ranged between $33.6 \mathrm{mg} / \mathrm{l}$ and $55 \mathrm{mg} / \mathrm{l}$ for 1996. Uranium concentrations analyzed in samples from the spring were between $6.5 \mathrm{pCi} / 1$ $(0.24 \mathrm{~Bq} / \mathrm{l})$ and $122 \mathrm{pCi} / 1(4.51 \mathrm{~Bq} / 1)$, with a mean value of $81.23 \mathrm{pCi} / 1(3.01 \mathrm{~Bq} / \mathrm{l})$. These values are within the historical range for uranium. Nitroaromatic compounds were analyzed in samples from base stage flow only. The concentrations of detected nitroaromatic compounds are within historical ranges. These compounds include 2,4,6-TNT $(0.04 \mu \mathrm{g} / \mathrm{l}), 2,4-\mathrm{DNT}(0.05 \mu \mathrm{g} / 1)$ and 2,6-DNT $(0.12 \mu \mathrm{g} / 1)$.

VOCs were monitored at SP-5303, SP-5304, SP-6301, and SP-6303 during 1997 to assess the potential for off-site migration of TCE that was detected in groundwater in the vicinity of the raffinate pits. TCE was detected at concentrations between $1 \mu \mathrm{g} / 1$ and $2 \mu \mathrm{g} / 1$ for three of the monthly VOC sampling events at SP-6301.

Monitoring of Burgermeister Spring will continue for the duration of the project to determine whether remediation activities across the northern half of the chemical plant impact the local groundwater quality. 


\subsubsection{Chemical Plant Trend Analyses}

\section{Statistical Methods}

Statistical tests for time-dependent trends were performed on historical and 1997 groundwater data representing select groundwater wells. The constituents and locations that were selected for trending included total uranium, nitroaromatic compounds, and nitrate in samples from the chemical plant wells. These trend analyses were performed individually for each monitoring well and contaminant. The specific locations, parameters, and time periods selected for trending analyses are presented in Tables 8-9 through 8-11. The selected locations, parameters, and time periods were based on the historical site environmental remediation activities, historical groundwater monitoring data, and knowledge of the site processes. The number of observations and number of data reported as below the detection limit for each data set are also shown in the summary tables.

The computer program TREND, developed at Pacific Northwest Laboratory, was used to perform the formal groundwater trend testing. The trend method employed was the nonparametric Mann-Kendall test. This program was selected because it can easily facilitate missing data and does not require the data to conform to a particular distribution. The nonparametric method is valid for scenarios where there are a high number of non-detect data points.

The results of the TREND analyses indicate the potential presence of statisticallysignificant trends and their direction upward or downward. The slope of each identified trend was also estimated with the results reported in concentration units per year. A $95 \%$ confidence interval about each slope line was calculated to indicate the variability (variance) in the values about this trend line. The trend testing output data are to be interpreted as screening indicators based on existing cumulative data. The results of the analyses are not intended to be used for the prediction of future concentrations. Rather, the data are to be used to indicate areas that should be more closely monitored in the future.

The TREND program was selected because it can easily facilitate missing data and does not require the data to conform to a particular distribution (such as a normal or lognormal distribution). The nonparametric method used in this program is valid for scenarios where there are a high number of non-detect data points. Data reported as trace concentrations or less than the detection limit can be used by assigning them a common value that is smaller than the smallest measured value in the data set (i.e., one-half the specified quantitation limit). This approach is valid since only the relative magnitudes of the data, rather than their measured values, are used in the method. The TREND program was also used in past analyses of the site groundwater data. Thus, use of the TREND program offered the advantage of maintaining continuity in the analysis methodology. The two-tailed version of the Mann-Kendall test was employed to detect either an 
Table 8-9 Chemical Plant Groundwater Wells Nitroaromatics Trend Analysis Summary

\begin{tabular}{|c|c|c|c|c|c|c|c|c|}
\hline & & & $\begin{array}{c}\text { NO. OF } \\
\text { OBSERVATIONS }\end{array}$ & $\begin{array}{l}\text { NO. OF } \\
\text { NON- } \\
\text { DETECT } \\
\text { DATA }\end{array}$ & $\begin{array}{c}\text { TREND } \\
\text { DIRECTION } \\
\end{array}$ & $\begin{array}{l}\text { SLOPE } \\
\text { (mg/l/yr) }\end{array}$ & $\begin{array}{l}\text { 95\% UPPER } \\
\text { AND LOWER } \\
\text { CONFIDENCE } \\
\text { INTERVALS }\end{array}$ & 1997 NEW HIGH \\
\hline WELL ID & LOCATION & COMPOUND & 1994-1997 & 1994-1997 & $\begin{array}{l}\text { (ALPHA - } \\
0.5) 1994- \\
1997\end{array}$ & 1994-1997 & $\begin{array}{c}\text { ON SLOPE } \\
\text { ( } \mu \mathrm{g} / / / \mathrm{yr}) 1994- \\
1997\end{array}$ & $\begin{array}{c}\text { CONCENTRATION } \\
\text { (mg/l) } \\
1994 \text { TO DATE }\end{array}$ \\
\hline \multirow[t]{2}{*}{ MW2001 } & West of Ash Pond & 2,4-DNT & 5 & 0 & $\mathrm{U}$ & -0.14 & $-0.035,0.007$ & No \\
\hline & & 2,6-DNT & 5 & 0 & $\mathrm{U}$ & -0.001 & $-0.012,0.007$ & No \\
\hline \multirow[t]{2}{*}{ MW2002 } & West of Ash Pond & 2,4-DNT & 5 & 0 & $\mathrm{D}$ & -0.017 & $-0.028,-0.008$ & No \\
\hline & & 2,6-DNT & 5 & 0 & $\mathrm{D}$ & -0.170 & $-0.288,-0.124$ & No \\
\hline \multirow[t]{2}{*}{ MW2005 } & North Dump Area & 2,4-DNT & 5 & 0 & $\mathrm{~s}$ & -0.004 & $-0.021,-0.008$ & No \\
\hline & & 2,6-DNT & 5 & 0 & $\mathrm{~s}$ & -0.004 & $-0.018,-0.008$ & No \\
\hline \multirow[t]{2}{*}{ MW2006 } & Northwest Frog Pond & 2,4-DNT & 5 & 0 & $S$ & -0.007 & $-0.113,-0.076$ & No \\
\hline & & 2,6-DNT & 6 & 0 & $\mathrm{~S}$ & -0.100 & $-0.975,0.387$ & No \\
\hline \multirow[t]{3}{*}{ MW2010 } & West Frog Pond & $2,4,6-T N T$ & 6 & 0 & $\mathrm{~S}$ & -0.075 & $-0.104,-0.033$ & No \\
\hline & & 2,4-DNT & 6 & 0 & $S$ & 0.000 & $-0.007,0.015$ & No \\
\hline & & 2,6-DNT & 6 & 0 & $S$ & 0.100 & $-0.030,0.308$ & No \\
\hline \multirow[t]{3}{*}{ MW2013 } & Southeast Frog Pond & 2,4,6-TNT & 6 & 0 & $\mathrm{~s}$ & 0.140 & $0.005,0.285$ & 0.88 \\
\hline & & $2,4-D N T$ & 6 & 0 & $\mathrm{~S}$ & 0.040 & $-0.087,0.092$ & No \\
\hline & & 2,6-DNT & 6 & 0 & $\mathrm{~S}$ & -0.933 & $-1.400,-0.175$ & No \\
\hline \multirow[t]{2}{*}{ MW-2014 } & Southeast Frog Pond & 2,4-DNT & 6 & 0 & 5 & -0.010 & $-0.030,0.003$ & No \\
\hline & & 2,6-DNT & 6 & 0 & $S$ & 0.015 & $-0.058,0.116$ & No \\
\hline \multirow[t]{3}{*}{ MW2032 } & MSAVMSA Area & $2,4,6-\mathrm{TNT}$ & 8 & 0 & D & -1.800 & $-3.362,-1.216$ & No \\
\hline & & 2,4-DNT & 8 & 0 & $\mathrm{D}$ & -0.025 & $-0.328,-0.020$ & No \\
\hline & & 2,6-DNT & 8 & 0 & $\mathrm{D}$ & -1.313 & $-1.973,-0.986$ & No \\
\hline \multirow[t]{3}{*}{ MW2033 } & Southeast Frog Pond & $2,4,6-\mathrm{TNT}$ & 7 & 0 & $\mathrm{U}$ & 0.200 & $0.056,0.366$ & 1.40 \\
\hline & & 2,4-DNT & 7 & 0 & $\mathrm{~S}$ & -0.040 & $-0.316,0.269$ & No \\
\hline & & 2,6-DNT & 7 & 0 & $\mathrm{~S}$ & -0.050 & $-1.476,2.476$ & No \\
\hline \multirow[t]{3}{*}{ MW2037 } & \multirow{3}{*}{$\begin{array}{l}\text { West TSA-South RAF } \\
\text { Pit } 4\end{array}$} & $2,4,6-\mathrm{TNT}$ & 17 & 17 & (a) & (a) & (a) & No \\
\hline & & 2,4-DNT & 17 & 0 & $\mathrm{~s}$ & -0.023 & $-0.045,0.016$ & 0.66 \\
\hline & & 2,6-DNT & 17 & 0 & $S$ & -0.007 & $-0.015,0.000$ & No \\
\hline \multirow[t]{3}{*}{ MW2038 } & \multirow[t]{3}{*}{ South RAF Pit 3} & $2,4,6-T N T$ & 17 & 17 & (a) & (a) & (a) & No \\
\hline & & 2,4-DNT & 17 & 0 & $\mathrm{D}$ & -0.200 & $-0.200,-0.102$ & No \\
\hline & & 2,6-DNT & 17 & 0 & $\mathrm{D}$ & -0.040 & $-0.045,-0.033$ & No \\
\hline
\end{tabular}




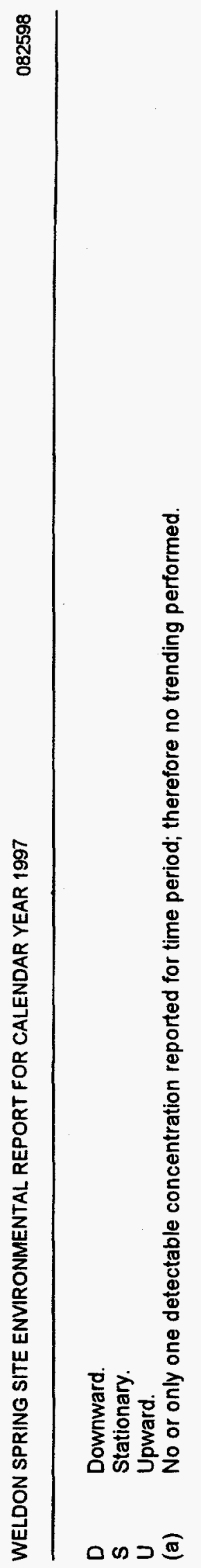


Table 8-10 Chemical Plant Groundwater Wells Total Uranium Trend Analysis Summary

\begin{tabular}{|c|c|c|c|c|c|c|c|}
\hline & & $\begin{array}{c}\text { NO. OF } \\
\text { OBSERVATIONS } \\
\end{array}$ & $\begin{array}{l}\text { NO. OF NON- } \\
\text { DETECT DATA }\end{array}$ & $\begin{array}{c}\text { TREND } \\
\text { DIRECTION }\end{array}$ & $\begin{array}{l}\text { SLOPE } \\
\text { (pCi/l/yr) }\end{array}$ & $\begin{array}{c}95 \% \text { UPPER AND } \\
\text { LOWER } \\
\text { CONFIDENCE }\end{array}$ & $\begin{array}{l}1997 \text { NEW HIGH } \\
\text { CONCENTRATION }\end{array}$ \\
\hline WELL ID & LOCATION & 1994-1997 & 1994-1997 & $\begin{array}{c}\text { (ALPHA }=0.5) \\
1994-1997\end{array}$ & 1994-1997 & $\begin{array}{l}\text { INTERVALS ON } \\
\text { SLOPE (pCi/l/yr) }\end{array}$ & $\begin{array}{c}(\mathrm{pCi} / \mathrm{l}) \\
1994 \text { TO DATE }\end{array}$ \\
\hline MW2003 & North of RAF Pit 4 & 5 & 0 & $\mathrm{~S}$ & 0.463 & $-0.059,0.897$ & 2.59 \\
\hline MW2017 & East Perimeter & 6 & 0 & $\mathrm{~s}$ & -0.797 & $-2.513,1.660$ & No \\
\hline$M W-2018$ & South Perimeter & 5 & 0 & $\mathrm{~s}$ & 0.130 & $-0.378,0.279$ & 1.89 \\
\hline MW2032 & MSACMSA Area & 10 & 0 & $\mathrm{~s}$ & -0.135 & $-0.736,0.303$ & No \\
\hline MW2033 & Southeast Frog Pond & 8 & 0 & $\mathbf{S}$ & -0.091 & $-0.572,0.276$ & No \\
\hline MW2039 & South RAF Pits $1 \& 2$ & 16 & 0 & $\mathrm{~s}$ & -0.017 & $-0.188,0.085$ & No \\
\hline MW3003 & North RAF Pit 4 & 9 & 0 & $S$ & -1.15 & $-5.893,2.092$ & No \\
\hline MW3019 & South TSA & 6 & 0 & $\mathrm{~s}$ & -0.230 & $-0.85,0.135$ & No \\
\hline MW3023 & North RAF Pit 4 & 8 & 0 & $\mathrm{~s}$ & 0.205 & $-3.040,3.741$ & No \\
\hline MW3025 & East RAF Pit 5 & 9 & 0 & $\mathrm{~s}$ & -0.200 & $-0.345,0.377$ & 3.56 \\
\hline $\mathrm{MW} 3027$ & Southwest RAF Pit 4 & 10 & 0 & $\mathrm{~s}$ & -0.010 & $-0.721,0.083$ & No \\
\hline MW4001 & $\begin{array}{l}\text { West Perimeter, RAF } \\
\text { Pit } 4\end{array}$ & 6 & 0 & $S$ & 0.059 & $-0.086,0.235$ & 0.766 \\
\hline MW4002 & $\begin{array}{l}\text { West Perimeter RAF } \\
\text { Pit } 4\end{array}$ & 5 & 1 & $\mathrm{~S}$ & -0.139 & $-0.347,0.070$ & No \\
\hline MW4005 & Southwest Perimeter & 6 & 1 & $s$ & 0.010 & $-0.610,3.669$ & No \\
\hline MW4015 & $\begin{array}{l}\text { North-Northeast } \\
\text { Perimeter }\end{array}$ & 6 & 2 & $S$ & 0.011 & $-4.967,0.058$ & No \\
\hline MW4018 & $\begin{array}{l}\text { East-Northeast } \\
\text { Perimeter } \\
\end{array}$ & 4 & 0 & S & -0.067 & $\mathrm{~N}$ to Small & No \\
\hline MW4019 & Southeast Perimeter & 6 & 1 & $S$ & -0.020 & $-0.648,0.214$ & No \\
\hline MW4020 & $\begin{array}{l}\text { East-Southeast } \\
\text { Perimeter }\end{array}$ & 10 & 0 & $\mathrm{~s}$ & 0.950 & $-2.298,2.000$ & 17.3 \\
\hline MW4021 & East Perimeter & 6 & 0 & $S$ & -0.407 & $-1.576,0.253$ & No \\
\hline MW4023 & $\begin{array}{l}\text { South-Southeast } \\
\text { Perimeter }\end{array}$ & 6 & 0 & S & -0.060 & $-0.827,0.352$ & No \\
\hline
\end{tabular}

D Downward

S Stationary

U Upward.

(a) None or only one detectable concentration reported for time period; therefore, no trending performed 
Table 8-11 Chemical Plant Groundwater Wells Nitrate Trend Analysis Summary

\begin{tabular}{|c|c|c|c|c|c|c|c|}
\hline & & $\begin{array}{c}\text { NO. OF } \\
\text { OBSERVATIONS }\end{array}$ & $\begin{array}{l}\text { NO. OF NON- } \\
\text { DETECT DATA }\end{array}$ & $\begin{array}{c}\text { TREND } \\
\text { DIRECTION } \\
\end{array}$ & $\begin{array}{l}\text { SLOPE } \\
\text { (mg/lyr) }\end{array}$ & $\begin{array}{c}9 \% \text { UPPER AND } \\
\text { LOWER } \\
\text { CONFIDENCE }\end{array}$ & $\begin{array}{l}1997 \text { NEW HIGH } \\
\text { CONCENTRATION }\end{array}$ \\
\hline WELL ID & LOCATION & 1994-1997 & 1994-1997 & $\begin{array}{c}(A L P H A=0.5) \\
1994-1997\end{array}$ & 1994-1997 & $\begin{array}{l}\text { INTERVALS ON } \\
\text { SLOPE (mg///yr) }\end{array}$ & $\begin{array}{c}(\mathrm{mg} / \mathrm{l}) \\
1994 \text { TO DATE }\end{array}$ \\
\hline MW2002 & West of Ash Pond & 6 & 0 & $\mathrm{~s}$ & -40.000 & -63.766 & No \\
\hline$M W-2003$ & \begin{tabular}{|c|} 
North of RAF Pit 4 \\
\end{tabular} & 6 & $\overline{0}$ & $\mathrm{~s}$ & -1.000 & $-24.604,140.848$ & No \\
\hline MW2005 & North Dump Area & 6 & 0 & s & 6.450 & $-13.144,11.081$ & 83.0 \\
\hline MW2023 & MSACMSA Area & 8 & 0 & $s$ & -4.962 & $-26.445,15.432$ & No \\
\hline MW2038 & South RAF Pit 3 & 22 & $\overline{0}$ & $\mathbf{S}$ & -15.000 & $-54.140,22.870$ & 1,000 \\
\hline MW2039 & South RAF Pits $1 \& 2$ & 19 & 0 & $\mathrm{~s}$ & 2.500 & $-1.723,6.337$ & 67.3 \\
\hline MW3003 & North RAF Pit 4 & 13 & 0 & 5 & 17.167 & $-21.012,32.677$ & No \\
\hline MW3023 & North RAF Pit 4 & 14 & $\overline{0}$ & $\bar{D}$ & -20.667 & $-31.285,-9.813$ & No \\
\hline MW3025 & East RAF Pit 5 & 15 & 0 & s & 5.000 & $-17.500,38.189$ & No \\
\hline MW3027 & Southwest RAF Pit 4 & 16 & 0 & $\bar{D}$ & -5.667 & $-7.343,-3.243$ & 453 \\
\hline MW4001 & $\begin{array}{l}\text { West Perimeter, RAF } \\
\text { Pit } 4\end{array}$ & 11 & 0 & $\mathrm{~s}$ & 1.833 & $-0.915,6.928$ & 47.2 \\
\hline MW4011 & $\begin{array}{l}\text { West Perimeter Ash } \\
\text { Pond }\end{array}$ & 6 & 0 & $s$ & 6.667 & $2.198,15.441$ & No \\
\hline
\end{tabular}

D Downward.

U Upward. 
upward or downward trend for each data set. In this approach, a test statistic, Z, is calculated. A positive value of $Z$ indicates an upward trend. Likewise, a negative value of $Z$ indicates a downward trend. The alpha value (or error limit) selected for testing was 0.05 . In the two-tailed test at the 0.05 alpha level of significance, the null hypothesis of "no trend" was rejected if the absolute value of the $Z$ statistic was greater than $Z_{1}-\alpha / 2$, where $Z_{1}-\alpha / 2$ was obtained from a cumulative normal distribution table. Thus, the absolute value of the TREND output statistic, $Z$ was compared to the table $Z .975$ value of 1.96 . If the absolute value of the $Z$ output statistic was greater than 1.96 , then a significant trend was reported.

One-half the specified quantitation limit (on the date of analysis) was used in the trend analysis for all data reported as below the detection limit. The purpose of using one-half the quantitation limit for non-detect data was to minimize the potential bias of the data. However, a consequence of this approach may be that, in some instances, the results may have been impacted by quantitation limits changing over time. The effect of varying quantitation limits is more likely to impact the trending analysis in instances where a large number of non-detect data are present within a given time series. The summary tables include the total number of data observations and the total number of non-detect data points for each data set so that this factor may be considered.

Graphs presenting the contaminant concentration versus time for each contaminant per trending location were developed. These graphs were used to identify suspect data outliers only for each trending analysis and are not presented in this report. No statistical tests were conducted for suspect outliers. Data that were suspect were flagged and rechecked for potential data transcription errors. No obvious errors were identified.

In general, data collected in 1994 were filtered using a 45-micron filter. Data collected in 1995 through 1997 were collected as non-filtered samples. In order to maintain continuity during the trending analyses, filtered data obtained during 1994 were omitted if both filtered and nonfiltered data were reported for the same period of time. Similarly, filtered data collected in 1995 through 1997 were also omitted if both filtered and non-filtered data were reported for the same time periods. Overall, filtered and non-filtered sampling results appeared to be very similar for the trend analysis parameters in concentration. This was evaluated by comparing filtered versus nonfiltered data for the same time period. Graphs were generated that presented the contaminant concentrations versus time for both cases. These graphs indicated that the difference between filtered and non-filtered concentrations for the same time periods was minimal.

In order to maintain sufficient power of the statistical tests, the analyses were limited to data sets with four or more data points. Therefore, if fewer than four detected concentrations were present in a given time series for a contaminant, the data set was not analyzed. These data sets are designated with an (a) in the summary tables, Tables 8-9 through 8-11. 
The linear slope of the trend was estimated for all data sets in which an upward or downward trend was identified. The slope was estimated using a nonparametric procedure included in the computer code for the TREND program. The estimates of the trend slope for all data sets with identified trends are provided in Tables 8-9 through 8-11. A 100(1- $\alpha$ )\% two-sided confidence interval about the true slope was also obtained by the nonparametric technique. The upper and lower $95 \%$ confidence limit estimates of the slope are included in the far right columns of the summary tables.

Trend analyses are intended to statistically indicate the presence of an upward or downward trend in contaminant concentration and should not be used as predicting future concentrations. The trend analyses should be used to identify site locations which may require close scrutiny during future monitoring.

\section{Nitroaromatic Compounds}

The only upward trends at the chemical plant for nitroaromatic compounds suggested by the trend analysis for 1995-1997 data were for TNT at MW-2033 and for DNT at MW-2001, located southeast of Frog Pond and west of Ash Pond, respectively. The trends were previously stationary at these locations and the recent upward trending may be responses to recent soil remediation activities in these areas. A summary of nitroaromatic trend analysis for the chemical plant is found in Table 8-9. Locations for trending were selected using historical data with nitroaromatic detections.

\section{Total Uranium}

Groundwater uranium analytical results were trended at locations representing all areas of the chemical plant. No upward or downward trends were detected. The uranium trend analysis is summarized in Table 8-10.

\section{Nitrate}

Nitrate concentrations were trended at locations along site perimeters and in the immediate vicinity of the raffinate pits. Upward nitrate trends were identified at locations MW-2001 (west of Ash Pond) and MW-4006 (west of Raffinate Pit 4). Downward trends were detected at MW-3023 (north of Raffinate Pit 4) and MW-3027 (southwest of Raffinate Pit 4). The unstable nitrate concentrations are most likely associated with remediation activities at Raffinate Pit 4, which were ongoing throughout 1997. The nitrate trend analyses are summarized in Table 8-11. 


\subsection{Weldon Spring Quarry}

\subsubsection{Hydrogeology}

The geology of the quarry area is separated into three units; upland overburden, Missouri River alluvium, and bedrock. The unconsolidated upland material overlying bedrock consists of up to $9.2 \mathrm{~m}(30 \mathrm{ft})$ of silty clay soil and loess deposits and is not saturated (Ref. 2). Three Ordovician-age formations comprise the bedrock at the quarry: The Kimmswick Limestone, the limestone and shale of the Decorah Group, and the Plattin Limestone. The alluvium along the Missouri River consists of clays, silts, sands, and gravels above the bedrock. The alluvium thickness increases with distance from the bluff towards the river where the maximum thickness is approximately $31 \mathrm{~m}(100 \mathrm{ft})$. The alluvium is truncated at the erosional contact with the Ordovician bedrock bluff (Kimmswick, Decorah, and Plattin formations) which also composes the rim wall of the quarry. The bedrock unit underlying the alluvial materials is the Decorah Group. Primary sediments between the bluff and the Femme Osage Slough are inorganic and organic intermixed and interlayered clays, silts, and sands with some organics.

The uppermost groundwater flow systems at the quarry are composed of alluvial and bedrock aquifers. The alluvial aquifer is predominantly controlled by recharge from the Missouri River and the bedrock aquifer is chiefly recharged by precipitation and overland runoff.

At the quarry, 17.monitoring wells are screened within either the Kimmswick-Decorah (upper unit) or Plattin Formations (lower unit) to monitor contaminants near the quarry within the bedrock (Figure 8-4). Twelve monitoring wells were installed to monitor contaminants within the Kimmswick-Decorah Formations comprising and surrounding the quarry. Three other monitoring wells are located south of the quarry within the Plattin Limestone to assess vertical contaminant migration. Two monitoring wells, one in the Kimmswick-Decorah Formation and one in the Plattin Formation, were installed north of the quarry to monitor upgradient groundwater quality.

There are 36 monitoring wells completed into the alluvium at the quarry and to the Missouri River. The wells west of the quarry monitor the uppermost water bearing unit below the quarry water treatment plant equalization basin and effluent ponds. The alluvium monitoring wells north of the Femme Osage Slough monitor contaminant migration south of the quarry, while those south of the slough monitor for possible migration of contaminants toward the well field. The St. Charles County monitoring wells, the RMW series wells, are designed to provide an early warning of contaminant migration toward the county production well field. The county production wells are monitored to verify the quality of the municipal well field water supply. 


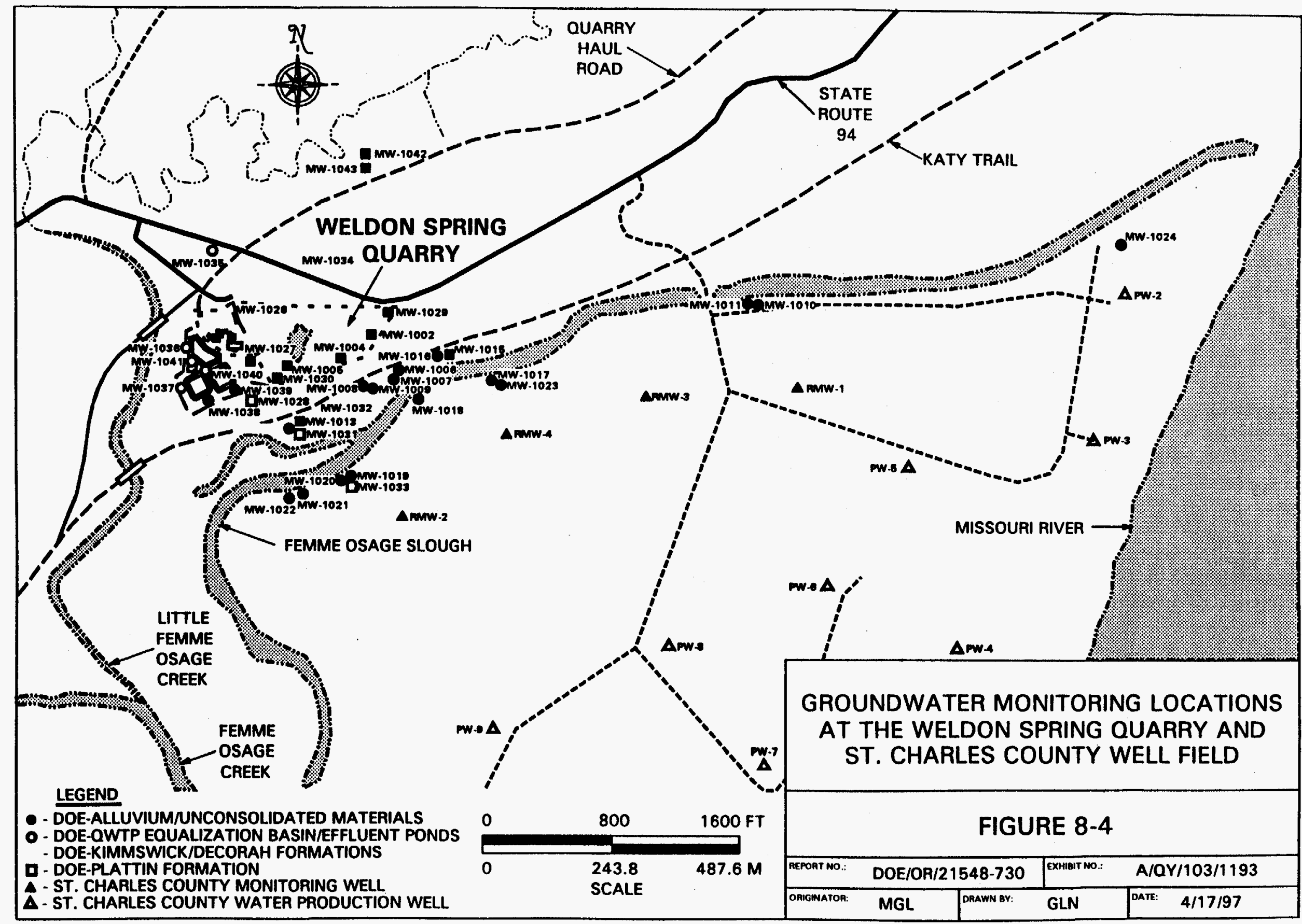


Monitoring wells MW-1042 (Plattin) and MW-1043 (Decorah) provide upgradient groundwater quality data for the central portion of the quarry. Monitoring wells MW-1034 (Kimmswick-Decorah) and MW-1035 (alluvium) are upgradient of the southwestern portion of the quarry. These upgradient wells provide an assessment of groundwater quality in these materials and provide background data. Eight groundwater monitoring wells located in the Darst Bottom area approximately $1.6 \mathrm{~km}(1 \mathrm{mi})$ southwest of the St. Charles County well field by the U.S. Geological Survey are utilized to study the upgradient characteristics of the Missouri River alluvium in the vicinity of the quarry. These wells provide a reference for background values in the well field area and have been sampled by both the USGS (1992) and the DOE (1994). A summary of background values used at the quarry is provided in Table 8-12.

\subsubsection{Monitoring Program}

Groundwater monitoring is performed in both the alluvial and bedrock aquifers at the quarry (Figure 8-4). Three separate monitoring programs were employed for the quarry in 1997. The first program addressed sampling the Department of Energy wells and monitoring the quarry area to determine contaminant migration and the effects of quarry dewatering and bulk waste removal, which began in mid-1993 and were completed in late-1995. The frequency of sampling for each location was based on the distance of the well from the source or migration pathway. Monitoring wells on the quarry rim were sampled bimonthly for total uranium and nitroaromatic compounds, due to the changes in concentrations over time, to better establish the trend in concentrations at these locations, and to monitor the effects of quarry dewatering and bulk waste removal activities on the groundwater system. All locations were sampled at least annually for radiochemical parameters and were qualitatively analyzed for nitroaromatic degradation products.

The second program monitors the St. Charles County well field and the associated water treatment plant. Active production wells, the St. Charles County RMW-series monitoring wells, and untreated and treated water from the County's public drinking water treatment plant were sampled quarterly or semiannually for selected parameters. This portion of the monitoring program was developed by representatives of the Department of Energy, several State regulatory agencies, and St. Charles County. 
Table 8-12 Mean Background Values for Quarry Groundwater Monitoring Locations

\begin{tabular}{|c|c|c|c|c|}
\hline \multicolumn{2}{|l|}{ PARAMETER } & $\begin{array}{l}\text { KIMMSWICKI } \\
\text { DECORAH } \\
\text { FORMATIONS(a) }\end{array}$ & $\begin{array}{l}\text { ALLUVIAL } \\
\text { UNCONSOLIDATED } \\
\text { MATERIALS(b) }\end{array}$ & $\begin{array}{l}\text { MISSOURI RIVER } \\
\text { ALLUVIUM(C) }\end{array}$ \\
\hline \multirow{2}{*}{$\begin{array}{l}\text { Total Uranium } \\
\text { (pCi/l) }\end{array}$} & Mean & 2.35 & 0.67 & 2.03 \\
\hline & $95 \%$ C.I. ${ }^{*}$ & $-1.18 ; 5.88$ & $-0.83 ; 2.16$ & $-2.71 ; 6.78$ \\
\hline \multirow[t]{2}{*}{ Radium-226 (pCi/l) } & Mean & 0.18 & 0.50 & 1.41 \\
\hline & $95 \%$ C.I.* & $\pm 0.78^{* \star}$ & $\pm 0.77^{\star \star \star}$ & $\pm 1.71^{\text {\# }}$ \\
\hline \multirow[t]{2}{*}{ Radium-228 (pCi/l) } & Mean & 0.77 & 0.48 & 1.59 \\
\hline & $95 \%$ C.I." & $\pm 2.06^{* \star *}$ & $\pm 2.06^{\star \star}$ & $\pm 13.1^{\text {\#* }}$ \\
\hline \multirow[t]{2}{*}{ Thorium-228 (pCi/l) } & Mean & 0.26 & 0.39 & 0.24 \\
\hline & $95 \%$ C.I. ${ }^{*}$ & $\pm 0.94^{* *}$ & $\pm 1.03^{\text {*t }}$ & $\pm 1.72^{* \star}$ \\
\hline \multirow{2}{*}{ Thorium-230 (pCi/l) } & Mean & 0.93 & 0.32 & 0.69 \\
\hline & $95 \%$ C.I.* & $\pm 0.55^{\text {t* }}$ & $\pm 0.94^{\text {t* }}$ & $\pm 2.93^{* *}$ \\
\hline \multirow[t]{2}{*}{ Thorium-232 (pCi/l) } & Mean & 0.26 & 0.12 & 0.20 \\
\hline & $95 \%$ C.1. ${ }^{*}$ & $\pm 0.92^{* \hbar}$ & $\pm 0.86^{\star * *}$ & $\pm 1.68^{* *}$ \\
\hline \multirow{2}{*}{$\begin{array}{l}\text { Gross } \alpha \\
\text { (pCi/l) }\end{array}$} & Mean & 6.75 & 1 & 1.54 \\
\hline & $95 \%$ C.I." & $\pm 6.85^{* *}$ & $\pm 3.5^{\text {** }}$ & $\pm 16.6^{\text {th }}$ \\
\hline \multirow{2}{*}{$\begin{array}{l}\text { Gross } \beta \\
(p C i / l)\end{array}$} & Mean & 5.77 & 5.9 & 3.0 \\
\hline & $95 \%$ C.1.* & $\pm 5.06^{\star \star \star}$ & \pm 2.5 & $\pm 13.9^{\text {t* }}$ \\
\hline $\begin{array}{l}\text { Nitroaromatic } \\
\text { Compounds }\end{array}$ & Mean & No detects & No detects & Not analyzed \\
\hline \multirow{2}{*}{$\begin{array}{l}\text { Arsenic } \\
(\mu \mathrm{g} / \mathrm{l})\end{array}$} & Mean & 1.38 & 1.53 & 4.08 \\
\hline & $95 \%$ C.I. ${ }^{*}$ & $-0.94 ; 3.70$ & $-0.99 ; 4.04$ & $-1.29 ; 9.46$ \\
\hline \multirow{2}{*}{$\begin{array}{l}\text { Barium } \\
(\mu g / l)\end{array}$} & Mean & 144.9 & 232.0 & 408.6 \\
\hline & $95 \%$ C.I." & $110.0 ; 179.8$ & $178.4 ; 285.6$ & $137.1 ; 680.0$ \\
\hline \multirow{2}{*}{$\begin{array}{l}\text { Nitrate } \\
(\mathrm{mg} / \mathrm{l})\end{array}$} & Mean & 1.06 & 0.11 & 0.46 \\
\hline & $95 \%$ C.I. & $-0.62 ; 2.73$ & $-0.05 ; 0.26$ & $-2.33 ; 3.24$ \\
\hline \multirow{2}{*}{$\begin{array}{l}\text { Sulfate } \\
\text { (mg/l) }\end{array}$} & Mean & 82.3 & 38.8 & 37.1 \\
\hline & $95 \%$ C.I." & $32.6 ; 132.0$ & $23.1 ; 54.5$ & $6.31 ; 68.0$ \\
\hline \multicolumn{5}{|c|}{$\begin{array}{l}\text { MW-1034 (DOE) } \\
\text { MW-1035 (DOE) } \\
\text { Darst Bottom Wells (USGS and DOE) } \\
95 \% \text { Confidence Interval about the mean } \\
\text { Average radiological error }\end{array}$} \\
\hline
\end{tabular}

The third program monitors the equalization basin and the two effluent ponds at the quarry water treatment plant (Figure 8-4). Monitoring wells MW-1035 through MW-1037, MW-1040, and MW-1041 were sampled quarterly and annually for selected parameters. The monitoring program was initially developed to meet the substantive requirements of 40 CFR Part 264, Subpart F, and 10 CSR Part 25.7, which require the monitoring of contaminants of concern in the groundwater beneath storage facilities. The contaminants of 
concern were derived from the Engineering Evaluation/Cost Analysis for the Proposed Management of Contaminated Water in the Weldon Spring Quarry (Ref. 40) and the Baseline Risk Evaluation for Exposure to Bulk Waste at the Weldon Spring Quarry, Weldon Spring, Missouri (Ref. 41).

\subsubsection{Weldon Spring Quarry Monitoring Results}

\subsubsection{Quarry}

Radiochemical Parameters. All groundwater monitoring wells at the quarry were sampled for the following radiochemical parameters: total uranium, $\mathrm{Ra}-226, \mathrm{Ra}-228$, isotopic thorium, gross alpha, and gross beta. The uranium values continue to indicate that the highest levels occur in the bedrock downgradient from the quarry and in the alluvial material north of the Femme Osage Slough. However, uranium concentrations decreased more than $10 \%$ in quarry rim bedrock monitoring locations, suggesting that quarry bulk waste remediation was successful in contaminant source removal. The 1997 annual averages for the locations that exceed background are summarized in Table 8-13.

Table 8-13 Annual Averages for Total Uranium (pci/l) Above Average Background at the Weldon Spring Quarry

\begin{tabular}{|l|l|l|l|l|}
\hline & & & & $\begin{array}{l}\text { ANNUAL AVERAGE } \\
\text { IOCATION }\end{array}$ \\
& ANNUAL AVERAGE & MAXIMUM & MINIMUM & $\begin{array}{l}\text { ANGE } \\
1996 \text { to } 1997\end{array}$ \\
\hline$M W-1002$ & 4.32 & 4.40 & 4.23 & NC \\
\hline$M W-1004$ & 2495 & 2530 & 2460 & $-6 \%$ \\
\hline$M W-1005$ & 2845 & 3380 & 2250 & $-54 \%$ \\
\hline$M W-1006$ & 2035 & 2800 & 1270 & $-29 \%$ \\
\hline$M W-1007$ & 47.4 & 61.5 & 33.3 & $-74 \%$ \\
\hline$M W-1008$ & 2385 & 2440 & 2330 & $-37 \%$ \\
\hline$M W-1013$ & 688 & 799 & 576 & $-8 \%$ \\
\hline$M W-1014$ & 864 & 1020 & 708 & $-9 \%$ \\
\hline$M W-1015$ & 216 & 273 & 158 & $-21 \%$ \\
\hline$M W-1016$ & 174 & 179 & 168 & NC \\
\hline$M W-1027$ & 151 & 201 & 120 & $-52 \%$ \\
\hline$M W-1030$ & 24.4 & 27.8 & 21.0 & $-47 \%$ \\
\hline$M W-1031$ & 117 & 118 & 116 & $-33 \%$ \\
\hline$M W-1032$ & 1280 & 1480 & 1080 & $+27 \%$ \\
\hline$M W-1038$ & 6.06 & 7.92 & 3.25 & $+24 \%$ \\
\hline
\end{tabular}

Note 1: $1 \mathrm{pCi} / \mathrm{l}=0.037 \mathrm{~Bq} / \mathrm{l}$.

NC No change, $\pm=\%$ increase or decrease from 1996 averages 
The proposed U.S. Environmental Protection Agency total uranium drinking water standard of $20 \mu \mathrm{g} / 1$ (13.6 pCi/l) was exceeded at MW-1004, MW-1005, MW-1006, MW-1007, MW-1008, MW-1013, MW-1014, MW-1015, MW-1016, MW-1027, MW-1030, MW-1031, and MW-1032. All of these monitoring wells are located north of the Femme Osage Slough and have no direct impact on the drinking water sources in the Missouri River alluvium. In comparison to 1996 data, eight of the locations show greater than a $20 \%$ reduction in uranium concentration and two show increases of greater than 20\% uranium concentration for 1997.

Ra-226, Ra-228, and isotopic thorium (Th-228, Th-230, and Th-232) were analyzed in 1997 at all groundwater monitoring locations at the quarry. Elevated radium levels were observed at seven locations in 1997 compared to 11 locations in 1996 . It is suspected that the elevated isotopic values in these wells resulted from bulk waste removal activities. Early 1994 operational data from the quarry pond had shown elevated levels of isotopes of radium and thorium in the runoff from waste removal operations and groundwater collected in the pond, which likely was due to disturbance of bulk wastes in the quarry. These levels began to decrease late in 1995 when bulk waste activities were completed and levels continued to decrease in 1997. Fluctuations of isotope concentrations were observed during 1996 to 1997, and are most likely responses to groundwater gradient changes (the quarry sump was not pumped during 1996). The 1997 annual averages above background concentrations are summarized in Table 8-14.

Table 8-14 Isotopic Radionuclide (pCi/l) Concentration Annual Averages That Exceeded Two Standard Deviations (Upper 95\% Confidence Interval) of Mean Background at the Weldon Spring Quarry

\begin{tabular}{|l|l|l|l|l|}
\hline LOCATION & RA-226 & RA-228 & TH-230 & TH-232 \\
\hline$M W-1005$ & 1.22 & - & - & - \\
\hline$M W-1012$ & - & 5.74 & - & - \\
\hline$M W-1014$ & - & 3.23 & - & - \\
\hline$M W-1015$ & - & 6.32 & - & - \\
\hline$M W-1016$ & - & 3.29 & - & - \\
\hline$M W-1017$ & 1.06 & - & - & - \\
\hline$M W-1023$ & 2.28 & - & 3.60 & 3.76 \\
\hline
\end{tabular}

- Did not exceed two standard deviations of mean background values.

Note 1: Values reported in activity.

Note 2: $1 \mathrm{pCi} / \mathrm{l}=0.037 \mathrm{~Bq} / \mathrm{l}$.

Nitroaromatic Compounds. In 1997, samples from all quarry monitoring wells were analyzed for nitroaromatic compounds. Nine locations yielded detectable concentrations of at least one of the six compounds analyzed during the 1997 sampling period. None of these concentrations indicate increasing impacts. These monitoring wells, which have historically been impacted with nitroaromatics, are situated in the alluvial materials or bedrock downgradient of the quarry and north of the Femme Osage Slough. Significant decreases in nitroaromatic compounds were observed in samples from quarry rim bedrock wells during 1997 . A 40\% decrease in TNT and $18 \%$ decrease in DNT (total) from 1996 values were reported for 1997 samples from these 
bedrock wells. No detectable concentrations were observed south of the Femme Osage Slough. A summary of the annual averages for these locations is provided in Table 8-15.

Table 8-15 Annual Averages for Detectable Concentrations of Nitroaromatic Compounds ( $\mu \mathrm{g} / \mathrm{l})$ at the Weldon Spring Quarry

\begin{tabular}{|l|l|l|l|l|l|l|}
\hline LOCATION & $1,3,5-$ TNB & $1,3-D N B$ & $2,4,6-$-TNT & $2,4-$ DNT & 2,6 -DNT & NB \\
\hline$M W-1002$ & 33 & 0.22 & 8.13 & 0.07 & 6.07 & $<0.03$ \\
\hline$M W-1004$ & 0.33 & 0.05 & 1.55 & 0.11 & 0.37 & $<0.03$ \\
\hline$M W-1005$ & $<0.03$ & $<0.09$ & $<0.03$ & $<0.03$ & 0.04 & $<0.03$ \\
\hline$M W-1006$ & 60.75 & $<0.09$ & 4.27 & 0.32 & 1.50 & $<0.03$ \\
\hline$M W-1008$ & 0.05 & $<0.09$ & 0.04 & $<0.03$ & 0.01 & $<0.03$ \\
\hline$M W-1013$ & $<0.03$ & $<0.09$ & $<0.03$ & 0.03 & 0.01 & $<0.03$ \\
\hline$M W-1015$ & 3.25 & 0.09 & 1.33 & $<0.03$ & 0.15 & $<0.03$ \\
\hline$M W-1016$ & 0.17 & $<0.09$ & 0.09 & $<0.03$ & 0.03 & $<0.03$ \\
\hline$M W-1027$ & 20.03 & $<0.09$ & 0.69 & 1.40 & 1.30 & $<0.03$ \\
\hline
\end{tabular}

The Missouri drinking water quality standard for $2,4-\mathrm{DNT}(0.11 \mu \mathrm{g} / \mathrm{l})$ was exceeded at MW-1004, MW-1006, and MW-1027. These locations are north of the Femme Osage Slough. No MCLs have been established for the other nitroaromatic compounds.

Sulfate. Groundwater analyses in 1997 indicated sulfate levels were elevated in the monitoring wells in the bedrock of the quarry rim and in the alluvial materials north of the Femme Osage Slough. Fourteen wells exceeded average background levels for sulfate. These wells are situated north of the slough, with the exception of MW-1018 located south of the slough, downgradient of the area of greatest groundwater impact. Only two locations (MW-1005 and MW-1007) exceeded the secondary MCL of $250 \mathrm{mg} / \mathrm{l}$. The annual averages for these wells are summarized in Table 8-16.

Table 8-16 Annual Averages for Sulfate $(\mathrm{mg} / \mathrm{l})$ Above Average Background at the Weldon Spring Quarry

\begin{tabular}{|l|l|l|l|}
\hline LOCATION & ANNUAL AVERAGE & MAXIMUM & MINIMUM \\
\hline$M W-1004$ & 124 & 132 & 109 \\
\hline$M W-1005^{*}$ & 661 & 815 & 514 \\
\hline$M W-1006^{*}$ & 206 & 236 & 190 \\
\hline$M W-1007$ & 88.9 & 304 & 0.21 \\
\hline$M W-1008$ & 108 & 147 & 70.9 \\
\hline$M W-1009$ & 153 & 161 & 141 \\
\hline$M W-1013$ & 91.68 & 93.6 & 90 \\
\hline$M W-1014$ & 95.6 & 96.5 & 94.9 \\
\hline$M W-1015$ & 127 & 145 & 112 \\
\hline$M W-1016$ & 148 & 156 & 140 \\
\hline
\end{tabular}


Table 8-16 Annual Averages for Sulfate (mg/l) Above Average Background at the Weidon Spring Quarry (Continued)

\begin{tabular}{|l|l|l|l|}
\hline LOCATION & ANNUAL AVERAGE & MAXIMUM & MINIMUM \\
\hline MW-1027 & 86.8 & 92.0 & 79.8 \\
\hline MW-1029 & 107 & 112 & 98.5 \\
\hline MW-1032 & 219 & 223 & 206 \\
\hline MW-1042 & 192 & 218 & 165 \\
\hline
\end{tabular}

* Exceeded secondary MCL of $250 \mathrm{mg} / \mathrm{l}$.

\subsubsection{St. Charles County Well Field}

Radiochemical Parameters. The St. Charles County production wells and the RMW-series monitoring wells were sampled semiannually for the radiochemical parameters Ra-226, Ra-228, and isotopic thorium. Gross alpha, and total uranium were analyzed quarterly. A summary of the radiochemical annual averages is provided in Table 8-17. The annual averages for total uranium in the well field remain at background. No production well exceeded the proposed groundwater standard of $20 \mu \mathrm{g} / 1(13.6 \mathrm{pCi} / 1)$.

Table 8-17 Summary of Annual Averages of Radiochemical Parameters $(\mathrm{pCi} /)$ for the St. Charles County Well Field

\begin{tabular}{|l|c|c|c|c|c|c|c|}
\hline LOCATION & $\begin{array}{c}\text { TOTAL } \\
\text { URANIUM }\end{array}$ & $\begin{array}{c}\text { GROSS } \\
\text { ALPHA }\end{array}$ & RA-226 & RA-228 & TH-228 & TH-230 & TH-232 \\
\hline MW-1024 & 1.05 & 6.30 & 0.46 & 1.28 & 0.17 & 0.26 & 0.13 \\
\hline MW-RMW1 & 1.02 & 3.42 & 0.72 & 1.14 & 0.07 & $<0.13$ & $0.04)$ \\
\hline MW-RMW2 & 5.99 & 6.86 & 0.24 & 1.26 & 0.09 & $<0.11$ & $<0.1$ \\
\hline MW-RMW3 & 0.69 & 2.76 & 0.51 & 1.01 & 0.11 & $<0.11$ & $(0.03)$ \\
\hline MW-RMW4 & 2.49 & 2.93 & 0.13 & 1.20 & 0.10 & $<0.13$ & $<0.13$ \\
\hline MW-PW02 & 0.44 & 2.72 & 0.91 & 0.83 & 0.06 & $<0.12$ & $<0.07$ \\
\hline MW-PWO3 & $<0.67$ & 2.75 & 0.46 & 0.67 & 0.06 & $<0.12$ & $<0.11$ \\
\hline MW-PW04 & $<0.60$ & 2.48 & 0.56 & 0.64 & 0.05 & $<0.09$ & $<0.07$ \\
\hline MW-PW05 & 0.19 & 2.65 & 0.47 & 0.89 & 0.07 & $<0.22$ & $<0.11$ \\
\hline MW-PW06 & 0.22 & 2.44 & 0.59 & 0.70 & 0.08 & $<0.10$ & $<0.08$ \\
\hline MW-PW07 & $<0.67$ & 2.20 & 0.68 & 0.95 & 0.11 & $<0.11$ & $<0.11$ \\
\hline MW-PW08 & 0.23 & 2.91 & 0.60 & 0.60 & 0.09 & $<0.09$ & $<0.06$ \\
\hline MW-PW09 & 0.28 & 3.29 & 0.86 & 1.79 & 0.07 & $<0.11$ & $<0.10$ \\
\hline MW-RAWW & 0.21 & 2.20 & 0.45 & 1.59 & 0.08 & $<0.05$ & $<0.08$ \\
\hline MW-FINW & 0.17 & 1.19 & 0.35 & $<0.07$ & 0.10 & $<0.10$ & $<0101$ \\
\hline
\end{tabular}

Note 1: $1 \mathrm{pCi} / \mathrm{l}=0.037 \mathrm{~Bq} / 1$.

The St. Charles County production wells, the RMW-series wells, and pretreated (MW-RAWW) and treated water (MW-FINW) from the St. Charles County water treatment plant were sampled quarterly for gross alpha. The annual averages for these locations are within the statistical variation of background ranges for groundwater occurring in the Missouri River alluvium. 
The Missouri Drinking Water Standard of $15 \mathrm{pCi} / 1(0.555 \mathrm{~Bq} / \mathrm{l})$ for gross alpha was not exceeded at any of the production wells. The St. Charles County treatment plant finished waters were in compliance with the gross alpha level of $10 \mathrm{pCi} / 1$ as established in $40 \mathrm{CFR} 141$ and endorsed in Department of Energy Order 5400.5.

The Missouri Drinking Water Standard of $5 \mathrm{pCi} / 1(0.185 \mathrm{~Bq} / \mathrm{l})$ for combined Ra-226 and Ra-228 was not exceeded at any of the St. Charles County production well locations. No water quality standards have been established for isotopic thorium in drinking water.

Nitroaromatic Compounds. The St. Charles County production wells and the RMW-series monitoring wells were sampled quarterly for the six nitroaromatic compounds. No detectable concentrations were observed at any of these locations.

Sulfate. The St. Charles County production wells were sampled semiannually and the RMW-series monitoring wells were sampled quarterly for sulfate. The sulfate concentrations in the well field were slightly elevated above pre-1995 levels for 1997 at MW-PW02, MW-PW03, MW-PW04, and MW-PW06 as they were in 1996. Most likely these levels are not related to any quarry operations. The elevated sulfate values are thought to reflect natural increases across the quarry area because a location upgradient monitoring location, $\mathrm{MW}-1035$, has also been increasing in sulfate since 1994. The 1997 annual averages for the well field are summarized in Table 8-18. The secondary MCL for sulfate is $250 \mathrm{mg} /$; this standard was not exceeded at any location in the well field.

Table 8-18

Annual Averages for Sulfate $(\mathrm{mg} / \mathrm{l})$, Arsenic $(\mu \mathrm{g} / \mathrm{l})$, and Barium $(\mu \mathrm{g} / \mathrm{l})$ in the St. Charles County Well Field

\begin{tabular}{|l|l|l|l|}
\hline LOCATION & SULFATE & ARSENIC & BARIUM \\
\hline MW-1024 & 1.14 & 9.95 & 461 \\
\hline MW-RMW1 & 25.4 & 13.0 & 468 \\
\hline MW-RMW2 & 17.3 & 128 & 341 \\
\hline MW-RMW3 & 29.1 & 35.9 & 434 \\
\hline MW-RMW4 & 39.7 & 12.3 & 201 \\
\hline MW-PW02 & 150 & 2.75 & 352 \\
\hline MW-PW03 & 143 & 3.25 & 300 \\
\hline MW-PW04 & 149 & 3.10 & 291 \\
\hline MW-PW05 & 101 & 4.25 & 341 \\
\hline MW-PWO6 & 125 & 3.80 & 306 \\
\hline MW-PW07 & 82.6 & 5.3 & 433 \\
\hline MW-PW08 & 50.5 & 5.80 & 433 \\
\hline MW-PW09 & 33.7 & 5.90 & 440 \\
\hline MW-RAWW & 99.7 & 3.8 & 357 \\
\hline MW-FINW & 81.5 & 3.5 & 88.5 \\
\hline
\end{tabular}

Metals. Arsenic and barium were the only metals monitored during 1997 at the St. Charles County well field. The primary MCL for arsenic $(50 \mu \mathrm{g} / \mathrm{l})$ was exceeded at location RMW-2. The MCL for barium $(2,600 \mu \mathrm{g} / \mathrm{l})$ was not exceeded at any location. None of the 
values for either metal exceeded their respective MCL's in samples from the public water supply wells or from the St. Charles County water treatment plant (Table 8-18).

\subsubsection{Trend Analysis}

Statistical tests for time-dependent trends at the Weldon Spring Quarry were performed on historical data from select groundwater wells. Trending was performed on total uranium, nitroaromatic, and sulfate data in 1997.

Trend analyses were performed at 16 monitoring locations based on historical data or knowledge of the quarry groundwater system. Total uranium trends were analyzed at locations down-gradient of bulk waste sources and in areas of possible impact south of the slough. Nitroaromatic compounds were analyzed for locations down-gradient of bulk waste sources. Sulfate trend analyses were performed for locations down-gradient of bulk waste sources and all locations adjacent to the south side of the slough, due to recent changes in levels in sulfate in this area.

The computer program TREND, previously described in detail in Section 8.4.4, was used to perform the formal groundwater trend testing. The trend method employed was the nonparametric Mann-Kendall test. The results of the TREND testing are shown in Tables 8-19 through 8-21.

\section{Nitroaromatic Compound Trend Results}

TREND analyses have been performed for the nitroaromatic data at the quarry since 1992 . Six of the DOE monitoring locations were selected for nitroaromatic TREND analyses based on the previously outlined criteria. Nitroaromatic analyses results are presented in Table 8-19. Based on the results of the analyses, no upward trends were identified in groundwater from the bedrock wells or alluvial wells that were analyzed for the 1994 to 1997 period. Nitroaromatic trend directions were downward in most wells that previously exhibited upward trends. The decreasing trends are likely the result of bulk waste removal at the quarry, which was completed in late 1995. 
Table 8-19 Quarry Groundwater Wells Nitroaromatics Trend Analysis Summary

\begin{tabular}{|c|c|c|c|c|c|c|c|c|}
\hline & & & $\begin{array}{c}\text { NO. OF } \\
\text { OBSERVATIONS } \\
\end{array}$ & $\begin{array}{c}\text { NO. OF } \\
\text { NON- } \\
\text { DETECT } \\
\text { DATA } \\
\end{array}$ & $\begin{array}{c}\text { TREND } \\
\text { DIRECTION } \\
\end{array}$ & 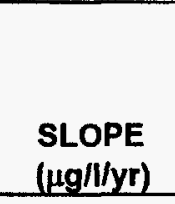 & $\begin{array}{l}\text { 95\% UPPER \& } \\
\text { LOWER } \\
\text { CONFIDENCE } \\
\text { INTERVALS ON } \\
\text { SLOPE }\end{array}$ & $\begin{array}{l}1997 \text { NEW HIGH } \\
\text { CONCENTRATION }\end{array}$ \\
\hline WELL ID & LOCATION & COMPOUND & 1994-1997 & 1994-1997 & $\begin{array}{c}\text { (ALPHA }=0.5) \\
1994-1997\end{array}$ & 1994-1997 & $\begin{array}{c}(\mu \mathrm{g} / 1 / \mathrm{yr}) 1994- \\
1997\end{array}$ & $\begin{array}{c}(\mu \mathrm{g} / \mathrm{l}) \\
1994 \text { TO DATE }\end{array}$ \\
\hline \multirow[t]{5}{*}{ MW1002 } & Bedrock-East rim & 2,4-DNT & 31 & 1 & $D$ & -0.030 & $-0.040,-0.025$ & No \\
\hline & & 2,6-DNT & 32 & 0 & $\mathrm{D}$ & -3.325 & $-4.803,-2.450$ & No \\
\hline & & 1,3-DNB & 32 & 2 & $D$ & -0.130 & $-0.167,-0.090$ & No \\
\hline & & $2,4,6-T N T$ & 32 & 0 & $D$ & -21.700 & $-30.232,-15.000$ & No \\
\hline & & $1,3,5$-TNB & 32 & 0 & $\mathrm{D}$ & -128.500 & $-170.000,-89.427$ & No \\
\hline \multirow[t]{4}{*}{ MW1004 } & Bedrock - rim & 2,4-DNT & 33 & 0 & 5 & -0.003 & $-0.010,0.003$ & No \\
\hline & & 2,6-DNT & 33 & 0 & $S$ & -0.036 & $-0.071,0.000$ & No \\
\hline & & $2,4,6-\mathrm{TNT}$ & 33 & 0 & 5 & -0.320 & $-0.085,0.100$ & No \\
\hline & & $1,3,5-$ TNB & 33 & 0 & $\mathrm{~s}$ & -0.090 & $-0.250,0.014$ & No \\
\hline \multirow[t]{5}{*}{ MW1006 } & \multirow{2}{*}{$\begin{array}{l}\text { Alluvium - North } \\
\text { of Slough }\end{array}$} & $2,4-\mathrm{DNT}$ & 19 & 4 & $\mathrm{~s}$ & -0.012 & $-0.089,0.063$ & No \\
\hline & & 2,6-DNT & 19 & 0 & $\mathrm{~S}$ & -0.217 & $0.100,0.221$ & No \\
\hline & & 1,3-DNB & 19 & 15 & $\mathrm{~S}$ & 0.000 & $-0.009,0.000$ & No \\
\hline & & $2,4,6-\mathrm{TNT}$ & 19 & 1 & $\mathrm{~s}$ & -1.417 & $-4.661,0.333$ & No \\
\hline & & $1,3,5-$ TNB & 19 & 0 & 5 & -8.092 & $-36.875,15.000$ & No \\
\hline \multirow[t]{5}{*}{ MW1015 } & \multirow{2}{*}{$\begin{array}{l}\text { Bedrock - North } \\
\text { of Slough }\end{array}$} & 2,4-DNT & 17 & 11 & D & -0.009 & $-0.011,-0.007$ & No \\
\hline & & 2,6-DNT & 17 & 1 & $D$ & -0.030 & $-0.040,-0.015$ & No \\
\hline & & 1,3-DNB & 17 & 7 & $S$ & -0.029 & $-0.055,0.000$ & No \\
\hline & & $2,4,6-\mathrm{TNT}$ & 17 & 0 & $\bar{D}$ & -0.720 & $-0.923,-0.450$ & No \\
\hline & & $1,3,5-\mathrm{TNB}$ & 17 & 0 & $\mathrm{D}$ & -1.612 & $-2.447,-0.781$ & No \\
\hline \multirow[t]{4}{*}{ NW1016 } & \multirow{2}{*}{$\begin{array}{l}\text { Alluvium - North } \\
\text { of Slough }\end{array}$} & 2,6-DNT & 17 & 1 & $\mathrm{~s}$ & -0.003 & $-0.011,0.002$ & No \\
\hline & & $1,3-\mathrm{DNB}$ & 17 & 17 & (a) & (a) & (a) & No \\
\hline & & $2,4,6-\mathrm{TNT}$ & 17 & 1 & $\mathrm{~s}$ & -0.004 & $-0.059,0.028$ & No \\
\hline & & $1,3,5-\mathrm{TNB}$ & 17 & 4 & 5 & -0.018 & $-0.182,0.055$ & No \\
\hline
\end{tabular}


Table 8-19 Quarry Groundwater Wells Nitroaromatics Trend Analysis Summary (Continued)

\begin{tabular}{|c|c|c|c|c|c|c|c|c|}
\hline & & & $\begin{array}{c}\text { NO. OF } \\
\text { OBSERVATIONS }\end{array}$ & $\begin{array}{l}\text { NO. OF } \\
\text { NON- } \\
\text { DETECT } \\
\text { DATA }\end{array}$ & $\begin{array}{l}\text { TREND } \\
\text { DIRECTION }\end{array}$ & $\begin{array}{l}\text { SLOPE } \\
(\mu g / / / y r)\end{array}$ & $\begin{array}{l}\text { 95\% UPPER } 8 \\
\text { LOWER } \\
\text { CONFIDENCE } \\
\text { INTERVALS ON } \\
\text { SLOPE }\end{array}$ & $\begin{array}{l}1997 \text { NEW HIGH } \\
\text { CONCENTRATION }\end{array}$ \\
\hline WELL ID & LOCATION & COMPOUND & 1994-1997 & 1994-1997 & $\begin{array}{c}\text { (ALPHA }=0.5) \\
1994-1997\end{array}$ & 1994-1997 & $\begin{array}{c}(\mu g / 1 / y r) 1994- \\
1997\end{array}$ & $\begin{array}{c}(\mu \mathrm{g} / \mathrm{l}) \\
1994 \text { TO DATE }\end{array}$ \\
\hline \multirow[t]{5}{*}{ MW1027 } & Bedrock - rim & 2,4-DNT & 18 & 1 & $S$ & 0.130 & $-0.251,0.894$ & No \\
\hline & & 2,6-DNT & 18 & 1 & 5 & -0.273 & $-0.679,0.096$ & 3.40 \\
\hline & & 1,3-DNB & 18 & 18 & (a) & (a) & (a) & No \\
\hline & & 2,4,6-TNT & 18 & 1 & D & -0.810 & $-1.650,-0.174$ & No \\
\hline & & $1,3,5-\mathrm{TNB}$ & 18 & 11 & $D$ & -0.024 & $-0.042,0.000$ & No \\
\hline
\end{tabular}

D Downward

S Stationary

U Upward 
Table 8-20 Quarry Groundwater Wells-Total Uranium Trend Analysis Summary

\begin{tabular}{|c|c|c|c|c|c|c|c|}
\hline & & $\begin{array}{c}\text { NO. OF } \\
\text { OBSERVATIONS }\end{array}$ & $\begin{array}{l}\text { NO. OF } \\
\text { NON- } \\
\text { DETECT } \\
\text { DATA }\end{array}$ & $\begin{array}{c}\text { TREND } \\
\text { DIRECTION }\end{array}$ & $\begin{array}{l}\text { SLOPE } \\
\text { (pCi///yr) }\end{array}$ & \multirow{2}{*}{$\begin{array}{l}95 \% \text { UPPER \& } \\
\text { LOWER } \\
\text { CONFIDENCE } \\
\text { INTERVALS ON } \\
\text { SLOPE (pCi///yr) } \\
1994-1997\end{array}$} & \multirow{2}{*}{$\begin{array}{c}1997 \text { NEW HIGH } \\
\text { CONCENTRATION } \\
\text { (PCI/I) } \\
1994 \text { TO DATE }\end{array}$} \\
\hline WELL ID & LOCATION & 1994-1997 & 1994-1997 & $\begin{array}{c}\text { (ALPHA = } \\
0.5) \\
1994-1997 \\
\end{array}$ & 1994-1997 & & \\
\hline MW1004 & Bedrock - rim & 22 & 0 & $\mathrm{~S}$ & -23.333 & $-200.000,110.000$ & No \\
\hline MW1006 & Alluvium-North of Slough & 12 & 0 & $\mathrm{~S}$ & -155.000 & $-623.702,327.377$ & No \\
\hline MW1007 & Alluvium-North of Slough & 13 & 0 & $\mathrm{~s}$ & -19.075 & $-236.277,11.563$ & No \\
\hline MW1008 & Alluvium-North of Slough & 13 & 0 & $\mathrm{~s}$ & 86.667 & $-190.00,617.022$ & No \\
\hline MW1009 & Alluvium-North of Slough & 12 & 1 & $\mathrm{~S}$ & -0.700 & $-3.147,1.004$ & No \\
\hline MW1013 & Bedrock-North of Slough & 12 & 0 & $\mathrm{~S}$ & -23.000 & $-66.533,30.121$ & No \\
\hline MW1014 & Alluvium-North of Slough & 12 & 0 & $\mathbf{S}$ & 31.667 & $-42.191,103.168$ & No \\
\hline MW1015 & Bedrock-North of Slough & 13 & 0 & $\mathrm{D}$ & -37.667 & $-71.542,-9.305$ & No \\
\hline MW1016 & Alluvium-North of Slough & 12 & 0 & $\mathrm{~s}$ & 2.000 & $-7.000,9.195$ & No \\
\hline MW1023 & Alluvium-South of Slough & 13 & 4 & $S$ & 0.068 & $-0.382,0.580$ & No \\
\hline MW1027 & Bedrock-rim & 13 & 0 & $\mathrm{~S}$ & -49.750 & $-94.667,1.799$ & No \\
\hline MW1030 & Bedrock-rim & 19 & 0 & $\mathrm{D}$ & -24.150 & $-41.371,-11.474$ & No \\
\hline MW1031 & Bedrock-North of Slough & 14 & 0 & $\mathrm{U}$ & 48.950 & $29.973,78.700$ & No \\
\hline MW1032 & Bedrock-North of Slough & 14 & 0 & $\mathrm{U}$ & 141.500 & $49.756,283.329$ & 1480.00 \\
\hline MW1034 & Bedrock-background & 11 & 0 & $S$ & -0.564 & $-1.844,0.074$ & No \\
\hline MW1035 & Alluvium-background & 17 & 1 & $S$ & 0.062 & $0.010,0.225$ & 2.10 \\
\hline
\end{tabular}

D Downward

U Upward 
Table 8-21 Quary Groundwater Wells Sulfate Trend Analysis Summary

\begin{tabular}{|c|c|c|c|c|c|c|c|}
\hline & & $\begin{array}{c}\text { NO. OF } \\
\text { OBSERVATIONS }\end{array}$ & $\begin{array}{l}\text { NO. OF } \\
\text { NON- } \\
\text { DETECT } \\
\text { DATA }\end{array}$ & $\begin{array}{c}\text { TREND } \\
\text { DIRECTION }\end{array}$ & $\begin{array}{l}\text { SLOPE } \\
(\mathrm{mg} / / / \mathrm{yr})\end{array}$ & \multirow{2}{*}{$\begin{array}{l}\text { 95\% UPPER \& } \\
\text { LOWER } \\
\text { CONFIDENCE } \\
\text { INTERVALS ON } \\
\text { SLOPE (mg/l/yr) } \\
1994-1997\end{array}$} & \multirow{2}{*}{$\begin{array}{c}1997 \text { NEW HIGH } \\
\text { CONCENTRATION } \\
\text { (mg/l) } \\
1994 \text { TO DATE }\end{array}$} \\
\hline WELL ID & LOCATION & 1994-1997 & 1994-1997 & $\begin{array}{c}\text { (ALPHA = } \\
0.5) \\
1994-1997\end{array}$ & 1994-1997 & & \\
\hline MW1002 & Bedrock - East rim & 19 & 0 & $\mathrm{U}$ & 8.700 & $6.389,10.400$ & No \\
\hline MW1004 & Bedrock - rim & 15 & 0 & $\mathrm{~s}$ & 4.333 & $-10.021,13.005$ & No \\
\hline MW1006 & Alluvium - North of Slough & 15 & 0 & $D$ & -54.500 & $-69.99,-40.015$ & No \\
\hline MW-1007 & Alluvium - North of Slough & 15 & 0 & $\mathrm{~s}$ & -7.435 & $-15.732,15.304$ & 304.00 \\
\hline MW1008 & Alluvium-North of Slough & 15 & 0 & $D$ & -42.000 & $-60.603,-29.029$ & No \\
\hline MW1009 & Alluvium-North of Slough & 15 & 0 & $\mathrm{D}$ & -11.667 & $-20.000,-3.059$ & No \\
\hline MW1013 & Bedrock-North of Slough & 15 & 0 & $\mathrm{~s}$ & 3.250 & $-0.033,7.797$ & No \\
\hline MW1014 & Alluvium-North of Slough & 13 & 0 & $\mathrm{~s}$ & 3.300 & $-2.669,6.269$ & No \\
\hline MW1015 & Bedrock-North of Slough & 15 & 0 & $\mathrm{~s}$ & 1.750 & $-2.283,7.308$ & No \\
\hline MW1016 & Alluvium-North of Slough & 15 & 0 & $\mathrm{U}$ & 7.167 & $2.029,11.662$ & No \\
\hline Mw1018 & Alluvium-South of Slough & 14 & 0 & $S$ & -4.950 & $-14.024,12.726$ & No \\
\hline MW1020 & Alluvium - South of Slough & 14 & 0 & $\mathrm{D}$ & -8.900 & $-13.003,-2.206$ & No \\
\hline MW1021 & Alluvium - South of Slough & 13 & 2 & $\mathrm{~s}$ & -0.160 & $-1.152,0.235$ & 5.40 \\
\hline MW1023 & Alluvium-South of Slough & 14 & 3 & $\mathrm{~s}$ & -0.400 & $-0.908,0.352$ & No \\
\hline MW1027 & Bedrock-rim & 13 & 0 & $\mathrm{~s}$ & 3.433 & $-0.886,10.000$ & No \\
\hline MW1029 & Bedrock - East rim & 12 & 0 & $U$ & 17.000 & $12.036,21.500$ & 112.00 \\
\hline MW1030 & Bedrock-rim & 14 & 0 & $\mathrm{D}$ & -3.500 & $-11.092,-0.723$ & No \\
\hline MW1031 & Bedrock-North of Slough & 16 & 0 & $\mathrm{U}$ & 13.100 & $3.374,34.407$ & No \\
\hline MW1032 & Bedrock-North of Slough & 14 & 0 & $\mathrm{~S}$ & 1.667 & $-11.000,18.643$ & No \\
\hline MW1034 & Bedrock-background & 16 & 0 & $\mathrm{D}$ & -7.500 & $-10.723,-4.279$ & No \\
\hline MW1035 & Alluvium-background & 17 & 0 & $U$ & 4.500 & $1.738,6.669$ & No \\
\hline
\end{tabular}

$\begin{array}{ll}\text { D } & \text { Downward } \\ \text { S } & \text { Stationary } \\ \text { U } & \text { Upward }\end{array}$


Total Uranium Trend Results

Total uranium trends for 1994-1997 data were stationary at all but four locations. Cumulative data for 1994 through 1997 for MW-1015 and MW-1030 indicate a downward trend. Data MW-1031 and MW-1032 indicate an upward trend. The stationary and downward trends of the quarry rim wells (which are similar to nitroaromatic compound trends), may be due to bulk waste removal at the quarry. Upward trends north of the slough may be responses to disturbances within the quarry during remediation. These responses, similar to those observed in quarry rim wells during 1994 through 1995, are thought to be appearing later at the north slough locations because of the greater distance from the remediation activities to the slough. The uranium trend analyses are summarized in Table 8-20.

\section{Sulfate Trend Analysis Results}

As shown in Table 8-21, sulfate sampling data for 1994 through 1997 for five locations indicated an upward trend. The locations with upward trends include the quarry rim and locations north and south of the Femme Osage Slough. These locations include both bedrock and alluvial wells. It is possible that apparent increases at these locations are actually re-adjustments toward natural conditions that appear elevated in comparison to groundwater that may have been influenced by surface water from flooding during 1993 and 1994. The location of MW-1035 is hydraulically upgradient of the quarry. The location of MW-1035 was selected to represent background conditions. Data for four alluvial well locations and two bedrock well locations indicated downward trends for 1994 through 1997. The results of all other analyses for this period indicated stationary trends. The sulfate analyses results are summarized in Table 8-21.

\subsection{Waste Treatment Facilities}

\subsubsection{Monitoring Program}

Groundwater monitoring wells have been placed around three waste management units: the quarry and site water treatment plant equalization basins, and the temporary storage area (see Figures 8-2 and 8-4). These wells were installed to detect contaminants in the uppermost water units beneath these storage facilities in order to comply with the requirements of 40 CFR 264, Subpart F, and 10 CSR 264, Subpart F. The monitoring parameters were derived from previous evaluations performed and documented in the Engineering Evaluation/Cost Analysis for the Proposed Management of Contaminated Water in the Weldon Spring Quarry (Ref. 40) and the Baseline Risk Evaluation for Exposure to Bulk Wastes at the Weldon Spring Quarry, Weldon Spring, Missouri (Ref. 41). 

parameters:

The detection monitoring program consists of quarterly sampling for the following

- Total uranium.

- Anions (nitrate, sulfate, chloride, and fluoride).

- Metals (arsenic, barium, cadmium, chromium, lead, mercury, selenium, and silver).

- Nitroaromatic compounds.

Annual sampling is performed for the following parameters:

- Radiochemical parameters (Ra-226, Ra-228, Th-230, Th-232, U-234, and U-238).

- Polychlorinated biphenyls (PCBs).

- Polynuclear aromatic hydrocarbons (PAH).

- Pesticides (endrin, lindane, methoxychlor, toxaphene, 2,4-D, and 2,4,5-TP Silvex).

Constituent concentrations at the monitoring wells for 1997 were compared with previously determined baseline concentrations for each well. If there was statistically significant evidence of contamination (concentration exceeds baseline by three standard deviations), a program of increased monitoring and/or an evaluation of the leachate collected within the liners of the basins or storage area was initiated.

\subsubsection{Site Water Treatment Plant and Temporary Storage Area Monitoring Results}

Collection of baseline data for the wells surrounding the equalization basin for the site water treatment plant and the temporary storage area was completed in December of 1994 . The baseline dataset for each monitoring well was established with a minimum of eight samples collected on a quarterly basis. A statistical summary of these baseline data for wells MW-2035 through MW-2043 can be found in Table 8-22. Monitoring data collected during 1997 were compared with the baseline data to identify significant changes in groundwater quality potentially attributable to operation of these facilities.

Primary and secondary drinking water standards were not exceeded, except for nitrate at well locations MW-2037 through MW-2042, mercury at locations MW-2037 and MW-2038, selenium at the MW-2041 location, and 2,4-DNT at locations MW-2037 and MW-2038. Elevated selenium and nitrate levels are potentially due to the facility's close proximity to the raffinate pits.

Baseline concentrations for the metals barium and chromium were slightly exceeded at MW-2039 (barium) and MW-2040 (chromium). These apparent concentration elevations are most likely attributable to changes in sample collection and preparation methodologies rather than actual groundwater conditions. Baseline values were established from analytical results of filtered 
samples collected during 1993 and 1994. Beginning in 1995, groundwater samples were no longer filtered due to a change in project sampling procedures pursuant to U.S. Environmental Protection Agency (EPA) sampling guidelines. Metals potentially adhering to suspended solids or precipitates, which had been filtered out prior to 1995, were not filtered from the 1997 samples. Despite the changes in the groundwater metals values, there is no evidence that the integrity of the water treatment facilities or TSA basins has been compromised. There were no elevated metals detected in collected leachate and no increased volume of leachate at these facilities.

Nitrate baseline was not exceeded at any location at the site water treatment facility equalization basin. All locations at the water treatment plant and TSA are stable or decreasing in nitrate concentrations. Sulfate baselines were not exceeded at any location. None of the locations exceeded the drinking water standard of $250 \mathrm{mg} / \mathrm{l}$ in 1997.

Nitroaromatic compounds were detected at locations MW-2037, MW-2038, and MW-2043. These detectable nitroaromatics were below baseline concentrations at all monitoring locations. 
Table 8-22 Baseline for the Detection Monitoring System at the Weldon Spring Site Water Treatment Plant and Temporary Storage Area

\begin{tabular}{|c|c|c|c|c|c|c|c|c|c|}
\hline PARAMETER & MW-2035 & MW-2036 & MW-2037 & MW-2038 & MW-2039 & MW-2040 & MW-2041 & $\mathrm{MW}-2042$ & MW-2043 \\
\hline $\begin{array}{l}\text { Arsenic } \\
(\mu g / /)\end{array}$ & 2.25 & 2.09 & 1.82 & 5.77 & 2.43 & 4.12 & 4.35 & 3.41 & 2.10 \\
\hline $\begin{array}{l}\text { Barium } \\
(\mu \mathrm{g} /))\end{array}$ & 107 & 333 & 250 & 563 & 240 & 962 & 347 & 590 & 344 \\
\hline $\begin{array}{l}\text { Cadmium } \\
(\mu \mathrm{g} / \mathrm{l})\end{array}$ & 3.91 & 3.89 & 3.67 & 3.67 & 6.98 & 4.04 & 4.20 & 3.80 & 3.79 \\
\hline $\begin{array}{l}\text { Chromium } \\
(\mu \mathrm{g} / \mathrm{l})\end{array}$ & 4.21 & 4.33 & 3.83 & 3.83 & 14.1 & 14.1 & 18.4 & 6.62 & 4.52 \\
\hline $\begin{array}{l}\text { Lead } \\
(\mu \mathrm{g} / \mathrm{l})\end{array}$ & 4.08 & 2.17 & 1.65 & 1.65 & 1.50 & 3.30 & 8.53 & 2.40 & 2.81 \\
\hline $\begin{array}{l}\text { Mercury } \\
(\mu \mathrm{g} / 1)\end{array}$ & 0.14 & 0.14 & 3.40 & 4.37 & 0.15 & 0.12 & 0.59 & 0.13 & 0.15 \\
\hline $\begin{array}{l}\text { Selenium } \\
(\mu \mathrm{g} / \mathrm{l})\end{array}$ & 4.71 & 1.86 & 20.0 & 24.9 & 24.5 & 9.42 & 96.6 & 4.11 & 7.11 \\
\hline $\begin{array}{l}\text { Silver } \\
(\mu \mathrm{g} / \mathrm{l})\end{array}$ & 5.78 & 6.07 & 6.08 & 6.08 & 13.8 & 5.40 & 10.3 & 6.18 & 4.96 \\
\hline $\begin{array}{l}\text { Uranium } \\
\text { (pCi/l) }\end{array}$ & 1.93 & 1.64 & 2.17 & 2.32 & 4.12 & 4.64 & 8.35 & 3.33 & 2.34 \\
\hline $\begin{array}{l}\text { Nitrate } \\
(\mathrm{mg} / \mathrm{l})\end{array}$ & 2.05 & 5.03 & 668 & 2271 & 117 & 455 & 2256 & 13.8 & 8.03 \\
\hline $\begin{array}{l}\text { Sulfate } \\
\text { (mg/l) }\end{array}$ & 6.89 & 5.64 & 177 & 132 & 54.6 & 27.9 & 196 & 39.5 & 20.8 \\
\hline $\begin{array}{l}1,3,5-\text { TNB } \\
(\mu \mathrm{g} / 1)\end{array}$ & 0.02 & $0.02^{\prime}$ & 0.29 & 0.37 & 0.02 & 0.02 & 0.02 & 0.02 & 0.02 \\
\hline $\begin{array}{l}\text { TNT } \\
(\mu \mathrm{g} / 1)\end{array}$ & 0.02 & 0.02 & 0.02 & 0.02 & 0.02 & 0.02 & 0.02 & 0.02 & 0.02 \\
\hline $\begin{array}{l}2,4-D N T \\
(\mu \mathrm{g} / 1)\end{array}$ & 0.02 & 0.02 & 0.79 & 2.14 & 0.02 & 0.02 & 0.02 & 0.02 & 0.09 \\
\hline $\begin{array}{l}2,6-\mathrm{DNT} \\
(\mu \mathrm{g} / 1)\end{array}$ & 0.01 & 0.01 & 0.19 & 0.41 & 0.01 & 0.01 & 0.01 & 0.01 & 0.01 \\
\hline
\end{tabular}

Note: $1 \mathrm{pCi} / \mathrm{l}=0.037 \mathrm{~Bq} /$. 
No PCBs or pesticides were reported above detection limits at any of the locations. Total uranium at MW-2036 (2.09 pCi/l) was slightly above baseline $(1.64 \mathrm{pCi} / \mathrm{l})$ during 1997 . The difference between these two values $(0.45 \mathrm{pCi} / 1)$ is not significant. The 1997 detection monitoring data for the site water treatment plant and the TSA are summarized in Table 8-23.

\subsubsection{Quarry Water Treatment Plant Monitoring Results}

Monitoring wells MW-1035 through MW-1039 were installed in 1991 to monitor the shallow groundwater in the vicinity of the quarry water treatment plant. In 1993, two additional monitoring wells, MW-1040 and MW-1041, were installed closer to the equalization basin to better monitor the waste storage unit. Baseline has been established for these newer wells utilizing 1994 and 1995 quarterly data. Monitoring wells MW-1038 and MW-1039 were deleted from this monitoring program because they were located cross gradient from the equalization basin at a distance too far to adequately monitor the basin and are possibly downgradient of contaminant sources in the quarry.

The concentrations at the wells were compared to baseline for the parameters. The baseline parameters for each well are presented in Table 8-24 and the summary of 1997 detection monitoring results is given in Table 8-25. Samples were also analyzed for nitroaromatic compounds, pesticides, and PCBs. The baselines and analytical results are not shown in either table because these compounds do not naturally occur and have not been detected in the monitoring system.

The 1997 results of the comparison of the monitoring data to baseline indicated that, with the exception of minor exceedences, no radiological parameter was above baseline during the year. These minor exceedences are within error limits of the analytical methods and are questionable. Total uranium levels remain within baseline for all wells in the water treatment facility detection monitoring network. 
Table 8-23 Summary of the 1997 Detection Monitoring Data for the Weldon Spring Site Water Treatment Plant and Temporary Storage Area

\begin{tabular}{|c|c|c|c|c|c|c|c|c|c|c|}
\hline \multicolumn{2}{|c|}{ PARAMETERS } & MW-2035 & MW-2036 & MW-2037 & MW-2038 & MW-2039 & $M W-2040$ & $M W-2041$ & $M W-2042$ & MW-2043 \\
\hline $\begin{array}{l}\text { Arsenic } \\
\mu \mathrm{g} / \mathrm{l}\end{array}$ & $\begin{array}{l}\text { Average } \\
\text { max/min }\end{array}$ & $\begin{array}{l}<3.0 \\
\text { N.D. }\end{array}$ & $\begin{array}{l}2.01 \\
4.21 \text { N.D }\end{array}$ & $\begin{array}{l}<3.0 \\
\text { N.D. }\end{array}$ & $\begin{array}{l}<3.0 \\
\text { N.D. }\end{array}$ & $\begin{array}{l}1.26 \\
1.8 / 0.7 \\
\end{array}$ & $\begin{array}{l}1.84 \\
4.5 / N . . D .\end{array}$ & $\begin{array}{l}2.18 \\
5.5 / \text { N.D. }\end{array}$ & $\begin{array}{l}<2.0 \\
\text { N.D }\end{array}$ & $\begin{array}{l}<2.0 \\
\text { N.D. }\end{array}$ \\
\hline $\begin{array}{l}\text { Barium } \\
\mu \mathrm{g} / 1\end{array}$ & $\begin{array}{l}\text { Average } \\
\text { max/min }\end{array}$ & $\begin{array}{l}93.2 \\
101 / 88.6 \\
\end{array}$ & $\begin{array}{l}278 \\
298 / 263 \\
\end{array}$ & $\begin{array}{l}88.3 \\
99.7 / 66.2 \\
\end{array}$ & $\begin{array}{l}211 \\
245 / 253 \\
\end{array}$ & $\begin{array}{l}297 \\
349 / 253 \\
\end{array}$ & $\begin{array}{l}671 \\
784 / 597 \\
\end{array}$ & $\begin{array}{l}246 \\
274 / 226 \\
\end{array}$ & $\begin{array}{l}490 \\
535 / 453\end{array}$ & $\begin{array}{l}345 \\
358 / 336\end{array}$ \\
\hline $\begin{array}{l}\text { Cadmium } \\
\mu \mathrm{g} / \mathrm{I}\end{array}$ & $\begin{array}{l}\text { Average } \\
\text { max/min }\end{array}$ & $\begin{array}{l}0.20 \\
0.39 / \text { N.D. }\end{array}$ & $\begin{array}{l}<1.0 \\
\text { N.D. }\end{array}$ & $\begin{array}{l}0.50 \\
0.56 / \text { N.D. }\end{array}$ & $\begin{array}{l}1.17 \\
2.5 / \text { N.D. }\end{array}$ & $\begin{array}{l}0.30 \\
0.34 / \text { N.D. }\end{array}$ & $\begin{array}{l}<1.0 \\
\text { N.D. }\end{array}$ & $\begin{array}{l}<1.0 \\
\text { N.D. }\end{array}$ & $\begin{array}{l}<3.0 \\
\text { N.D. }\end{array}$ & $\begin{array}{l}0.5 \\
0.53 / \text { N.D. }\end{array}$ \\
\hline $\begin{array}{l}\text { Chromium } \\
\mu \mathrm{g} / \mathrm{l}\end{array}$ & $\begin{array}{l}\text { Average } \\
\text { max/min }\end{array}$ & $\begin{array}{l}1.03 \\
2.10 / \text { N.D. }\end{array}$ & $\begin{array}{l}0.8 \\
1.0 / \text { N.D. }\end{array}$ & $\begin{array}{l}2.46 \\
14.2 / \text { N.D. }\end{array}$ & $\begin{array}{l}<3.0 \\
\text { N.D. }\end{array}$ & $\begin{array}{l}5.11 \\
8.0 / 3.3 \\
\end{array}$ & $\begin{array}{l}16.6 \\
25.2 / 12.2 \\
\end{array}$ & $\begin{array}{l}0.60 \\
0.69 / \text { N.D. }\end{array}$ & $\begin{array}{l}1.3 \\
1.4 / \text { N.D. }\end{array}$ & $\begin{array}{l}3.7 \\
3.9 / \text { N.D. }\end{array}$ \\
\hline $\begin{array}{l}\text { Lead } \\
\mu g / l\end{array}$ & $\begin{array}{l}\text { Average } \\
\text { max/min }\end{array}$ & $\begin{array}{l}<2.0 \\
\text { N.D. }\end{array}$ & $\begin{array}{l}<2.0 \\
\text { N.D. }\end{array}$ & $\begin{array}{l}1.37 \\
4.90 / \text { N.D. }\end{array}$ & $\begin{array}{l}<2.0 \\
\text { N.D. }\end{array}$ & $\begin{array}{l}1.09 \\
2.2 / \mathrm{N} . \mathrm{D} .\end{array}$ & $\begin{array}{l}3.11 \\
5.6 / \text { N.D. }\end{array}$ & $\begin{array}{l}<2.0 \\
\text { N.D. }\end{array}$ & $\begin{array}{l}<2.0 \\
\text { N.D. }\end{array}$ & $\begin{array}{l}<2.0 \\
\text { N.D. }\end{array}$ \\
\hline $\begin{array}{l}\text { Mercury } \\
\mu \mathrm{g} / \mathrm{l}\end{array}$ & $\begin{array}{l}\text { Average } \\
\text { max/min }\end{array}$ & $\begin{array}{l}<0.2 \\
\text { N.D. }\end{array}$ & $\begin{array}{l}<0.2 \\
\text { N.D. }\end{array}$ & $\begin{array}{l}3.59 \\
4.20 / 3.10\end{array}$ & $\begin{array}{l}1.20 \\
1.86 / 0.64\end{array}$ & $\begin{array}{l}<0.2 \\
\text { N.D. }\end{array}$ & $\begin{array}{l}<0.2 \\
\text { N.D. }\end{array}$ & $\begin{array}{l}<0.2 \\
\text { N.D. }\end{array}$ & $\begin{array}{l}<0.1 \\
\text { N.D. }\end{array}$ & $\begin{array}{l}>0.1 \\
\text { N.D. }\end{array}$ \\
\hline $\begin{array}{l}\text { Selenium } \\
\mu \mathrm{g} / 1\end{array}$ & $\begin{array}{l}\text { Average } \\
\text { max/min }\end{array}$ & $\begin{array}{l}2.44 \\
5.2 / \mathrm{N} . \mathrm{O} . \\
\end{array}$ & $\begin{array}{l}<3.0 \\
\text { N.D. }\end{array}$ & $\begin{array}{l}3.72 \\
5.9 / \text { N.D. }\end{array}$ & $\begin{array}{l}11.4 \\
14.4 / 3.90\end{array}$ & $\begin{array}{l}6.29 \\
12.3 / \text { N.D. } \\
\end{array}$ & $\begin{array}{l}4.08 \\
6.4 / \text { N.D. }\end{array}$ & $\begin{array}{l}13.8 \\
16.7 / 11.0\end{array}$ & $\begin{array}{l}<3.7 \\
\text { N.D. }\end{array}$ & $\begin{array}{l}<3.0 \\
\text { N.D. }\end{array}$ \\
\hline $\begin{array}{l}\text { Silver } \\
\mu \mathrm{g} / \mathrm{l}\end{array}$ & $\begin{array}{l}\text { Average } \\
\text { max/min }\end{array}$ & $\begin{array}{l}0.85 \\
1.9 / \text { N.D. }\end{array}$ & $\begin{array}{l}0.68 \\
1.2 / \text { N.D. }\end{array}$ & $\begin{array}{l}1.63 \\
3.2 / \text { N.D. }\end{array}$ & $\begin{array}{l}1.48 \\
2.6 / \text { N.D. }\end{array}$ & $\begin{array}{l}1.18 \\
2.8 / \text { N.D. }\end{array}$ & $\begin{array}{l}1.10 \\
2.1 / \text { N.D. }\end{array}$ & $\begin{array}{l}0.94 \\
1.6 / \text { N.D. }\end{array}$ & $\begin{array}{l}<1.8 \\
\text { N.D. }\end{array}$ & $\begin{array}{l}<1.8 \\
\text { N.D. }\end{array}$ \\
\hline $\begin{array}{l}\text { Total } \\
\text { Uranium } \\
\text { pCi/l }\end{array}$ & $\begin{array}{l}\text { Average } \\
\text { max/min }\end{array}$ & $\begin{array}{l}1.18 \\
3.59 / 0.34\end{array}$ & $\begin{array}{l}2.09 \\
6.59 / \text { N.D. }\end{array}$ & $\begin{array}{l}1.17 \\
1.28 / 1.01\end{array}$ & $\begin{array}{l}1.49 \\
1.57 / 1.41\end{array}$ & $\begin{array}{l}3.01 \\
3.29 / 2.71\end{array}$ & $\begin{array}{l}2.35 \\
2.55 / 2.23\end{array}$ & $\begin{array}{l}.54 \\
5.01 / 4.04\end{array}$ & $\begin{array}{l}2.60 \\
3.07 / 2.01\end{array}$ & $\begin{array}{l}1.82 \\
1.90 / 1.75\end{array}$ \\
\hline $\begin{array}{l}\text { Nitrate } \\
\mathrm{mg} / \mathrm{l}\end{array}$ & $\begin{array}{l}\text { Average } \\
\text { max/min }\end{array}$ & $\begin{array}{l}0.49 \\
0.78 / 10.26\end{array}$ & $\begin{array}{l}2.97 \\
3.62 / 2.38\end{array}$ & $\begin{array}{l}289 \\
320 / 248\end{array}$ & $\begin{array}{l}798 \\
1000 / 388\end{array}$ & $\begin{array}{l}57.1 \\
67.3 / 47.4\end{array}$ & $\begin{array}{l}155 \\
175 / 139\end{array}$ & $\begin{array}{l}154 \\
182 / 120\end{array}$ & $\begin{array}{l}6.01 \\
6.27 / 5.51\end{array}$ & $\begin{array}{l}7.28 \\
8.25 / 6.61\end{array}$ \\
\hline $\begin{array}{l}\text { Sulfate } \\
\mathrm{mg} / \mathrm{l}\end{array}$ & $\begin{array}{l}\text { Average } \\
\text { max/min }\end{array}$ & $\begin{array}{l}2.09 \\
2.63 / 1.72\end{array}$ & $\begin{array}{l}4.22 \\
4.72 / 3.81\end{array}$ & $\begin{array}{l}123 \\
140 / 113\end{array}$ & $\begin{array}{l}81.2 \\
93.2 / 71.1\end{array}$ & $\begin{array}{l}29.9 \\
32.1 / 28.4\end{array}$ & $\begin{array}{l}10.2 \\
11.1 / 9.48\end{array}$ & $\begin{array}{l}34.0 \\
39.0 / 30.6\end{array}$ & $\begin{array}{l}31.5 \\
32.4 / 30.3\end{array}$ & $\begin{array}{l}14.7 \\
14.8 / 14.6\end{array}$ \\
\hline $\begin{array}{l}1,3,5-\mathrm{TNB} \\
\mu \mathrm{g} / \mathrm{l}\end{array}$ & $\begin{array}{l}\text { Average } \\
\text { max/min }\end{array}$ & $\begin{array}{l}<0.03 \\
\text { N.D. }\end{array}$ & $\begin{array}{l}<0.03 \\
\text { N.D. }\end{array}$ & $\begin{array}{l}0.17 \\
0.17 / 0.16\end{array}$ & $\begin{array}{l}0.17 \\
0.18 / 0.14\end{array}$ & $\begin{array}{l}<0.03 \\
\text { N.D. }\end{array}$ & $\begin{array}{l}<0.03 \\
\text { N.D. }\end{array}$ & $\begin{array}{l}<0.03 \\
\text { N.D. }\end{array}$ & $\begin{array}{l}<0.03 \\
\text { N.D. }\end{array}$ & $\begin{array}{l}<0.03 \\
\text { N.D. }\end{array}$ \\
\hline $\begin{array}{l}\mathrm{TNT} \\
\mu \mathrm{g} / \mathrm{I}\end{array}$ & $\begin{array}{l}\text { Average } \\
\text { max/min }\end{array}$ & $\begin{array}{l}<0.03 \\
\text { N.D. }\end{array}$ & $\begin{array}{l}<0.03 \\
\text { N.D. }\end{array}$ & $\begin{array}{l}<0.03 \\
\text { N.D. }\end{array}$ & $\begin{array}{l}<0.03 \\
\text { N.D. }\end{array}$ & $\begin{array}{l}<0.03 \\
\text { N.D. }\end{array}$ & $\begin{array}{l}<0.03 \\
\text { N.D. }\end{array}$ & $\begin{array}{l}<0.03 \\
\text { N.D. }\end{array}$ & $\begin{array}{l}<0.03 \\
\text { N.D. }\end{array}$ & $\begin{array}{l}<0.03 \\
\text { N.D. }\end{array}$ \\
\hline $\begin{array}{l}2,4-D N T \\
\mu \mathrm{g} / 1\end{array}$ & $\begin{array}{l}\text { Average } \\
\text { max/min }\end{array}$ & $\begin{array}{l}<0.03 \\
\text { N.D. }\end{array}$ & $\begin{array}{l}<0.03 \\
\text { N.D. }\end{array}$ & $\begin{array}{l}0.59 \\
0.66 / 0.50\end{array}$ & $\begin{array}{l}1.30 \\
1.40 / 1.20\end{array}$ & $\begin{array}{l}<0.03 \\
\text { N.D. }\end{array}$ & $\begin{array}{l}<0.03 \\
\text { N.D. }\end{array}$ & $\begin{array}{l}<0.03 \\
\text { N.D. }\end{array}$ & $\begin{array}{l}<0.03 \\
\text { N.D. }\end{array}$ & $\begin{array}{l}0.08 \\
0.1 / 0.07\end{array}$ \\
\hline $\begin{array}{l}2,6-D N T \\
\mu \mathrm{g} / 1\end{array}$ & $\begin{array}{l}\text { Average } \\
\text { max/min }\end{array}$ & $\begin{array}{l}<0.01 \\
\text { N.D. }\end{array}$ & $\begin{array}{l}<0.01 \\
\text { N.D. }\end{array}$ & $\begin{array}{l}0.12 \\
0.14 / 0.13\end{array}$ & $\begin{array}{l}0.24 \\
0 ., 24 / 0.23\end{array}$ & $\begin{array}{l}<0.01 \\
\text { N.D. }\end{array}$ & $\begin{array}{l}<0.01 \\
\text { N.D. }\end{array}$ & $\begin{array}{l}<0.01 \\
\text { N.D. }\end{array}$ & $\begin{array}{l}<0.01 \\
\text { N.D. }\end{array}$ & $\begin{array}{l}<0.01 \\
\text { N.D. }\end{array}$ \\
\hline
\end{tabular}


Table 8-24 Baseline for the Detection Monitoring System at the Weldon Spring Quarry Water Treatment Plant

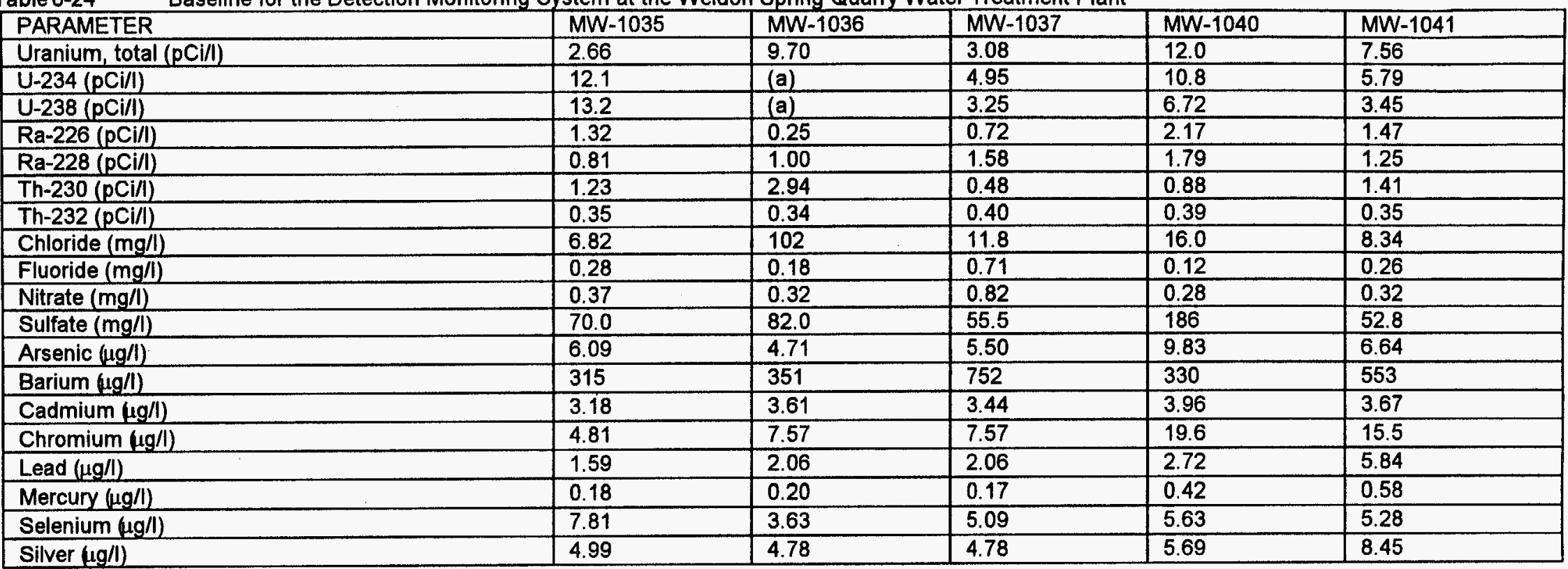

(a) No data available for determination of baseline

Note: $1 \mathrm{pCi} / \mathrm{l}=0.037 \mathrm{~Bq} / \mathrm{l}$. 
Table 8-25 Summary of the 1997 Detection Monitoring Data for the Weldon Spring Quarry Water Treatment Plant

\begin{tabular}{|c|c|c|c|c|c|c|}
\hline \multicolumn{2}{|l|}{ PARAMETER } & MW-1035 & $M W-1036$ & $M W-1037$ & MW-1040 & MW-1041 \\
\hline \multirow[t]{2}{*}{$\begin{array}{l}\text { Uranium, total } \\
(\mathrm{pCi} / \mathrm{l})\end{array}$} & average & 1.18 & 4.80 & 2.27 & 7.26 & 5.54 \\
\hline & $\mathrm{max} / \mathrm{min}$ & $2.10 / 0.40$ & $6.60 / 1.40$ & $4.60 / 1.08$ & $8.46 / 5.62$ & $9.25 / 2.70$ \\
\hline \multirow[t]{2}{*}{$\begin{array}{l}\text { Ra-226 } \\
(p C i / l)\end{array}$} & average & 0.04 & 0.52 & 0.25 & 1.01 & 0.56 \\
\hline & $\max / \min$ & -- & $-\infty$ & - & $\cdots$ & - \\
\hline \multirow[t]{2}{*}{$\begin{array}{l}\mathrm{Ra}-228 \\
(\mathrm{pCi} / \mathrm{l})\end{array}$} & average & N.D. & 0.03 & $<0.12$ & 0.13 & 1.22 \\
\hline & $\max / \min$ & - & - & $-\infty$ & -- & $\cdots$ \\
\hline \multirow[t]{2}{*}{$\begin{array}{l}\text { Th-228 } \\
(\mathrm{pCi} / \mathrm{l})\end{array}$} & average & 0.03 & 0.05 & 0.01 & 0.07 & 0.02 \\
\hline & $\max / \min$ & - & - & -- & - & -- \\
\hline \multirow[t]{2}{*}{$\begin{array}{l}\text { Th-230 } \\
(p C i / l)\end{array}$} & average & 0.04 & 0.42 & 0.82 & 0.54 & 0.36 \\
\hline & $\max / \min$ & - & - & - & - & -- \\
\hline \multirow{2}{*}{$\begin{array}{l}\text { Chloride } \\
(\mathrm{mg} / \mathrm{l})\end{array}$} & average & 2.69 & 117 & 3.61 & 27.6 & 5.98 \\
\hline & $\max / \min$ & $39.7 / 20.2$ & $131 / 102$ & $4.32 / 2.33$ & $33.9 / 19 / 1$ & $7.63 / 4.61$ \\
\hline \multirow{2}{*}{$\begin{array}{l}\text { Fluoride } \\
\text { (mg/l) }\end{array}$} & average & 0.38 & 0.68 & 0.64 & 0.6 & 0.51 \\
\hline & $\max / \min$ & $0.67 / 0.16$ & $1.12 / 0.19$ & $1.02 / 0.25$ & $1.12 / 0.18$ & $0.90 / 0.18$ \\
\hline \multirow[t]{2}{*}{$\begin{array}{l}\text { Nitrate } \\
\text { (mg/l) }\end{array}$} & average & 0.40 & 2.35 & 0.37 & 0.53 & 0.20 \\
\hline & $\max / \min$ & $0.68 / 0.13$ & $8.7 / 0.1$ & $0.89 /$ N.D. & $1.40 / 0.01$ & $0.37 / 0.01$ \\
\hline \multirow{2}{*}{$\begin{array}{l}\text { Sulfate } \\
(\mathrm{mg} / \mathrm{l})\end{array}$} & average & 48.9 & 107 & 155 & 216 & 47.4 \\
\hline & $\max / \min$ & $57.5 / 44.9$ & $155 / 61.5$ & $299 / 63.7$ & $298 / 141$ & $48.4 / 45.3$ \\
\hline \multirow{2}{*}{$\begin{array}{l}\text { Arsenic } \\
(\mu \mathrm{g} / \mathrm{l})\end{array}$} & average & 1.91 & 5.25 & 4.72 & $<2.0$ & 1.65 \\
\hline & $\max / \min$ & 3.1/N.D. & 9.8/N.D. & 7.4/N.D. & N.D. & 2.3/N.D. \\
\hline \multirow{2}{*}{$\begin{array}{l}\text { Barium } \\
(\mu \mathrm{g} / \mathrm{l})\end{array}$} & average & 286.5 & 113 & 351 & 186 & 371 \\
\hline & $\max / \min$ & $323 / 233$ & $166 / 53.0$ & $535 / 145$ & $201 / 163$ & $401 / 326$ \\
\hline
\end{tabular}


Table 8-25 Summary of the 1997 Detection Monitoring Data for the Weldon Spring Quarry Water Treatment Plant (Continued)

\begin{tabular}{|c|c|c|c|c|c|c|}
\hline \multicolumn{2}{|c|}{ PARAMETER } & MW-1035 & $M W-1036$ & MW-1037 & $M W-1040$ & $M W-1041$ \\
\hline \multirow{2}{*}{$\begin{array}{l}\text { Cadmium } \\
(\mu \mathrm{g} / \mathrm{l})\end{array}$} & average & 0.41 & $<2.0$ & 0.52 & $<1.0$ & $<1.0$ \\
\hline & $\max / \min$ & 1.0/N.D. & N.D. & $0.57 /$ N.D. & N.D. & N.D. \\
\hline \multirow{2}{*}{$\begin{array}{l}\text { Chromium } \\
(\mu \mathrm{g} / \mathrm{l})\end{array}$} & average & 3.38 & 6.74 & 9.24 & 0.87 & 0.62 \\
\hline & $\max / \min$ & $6.0 / 1.8$ & $19.2 / 2.0$ & 25:2/N.D. & $0.96 /$ N.D. & $0.77 /$ N.D. \\
\hline \multirow{2}{*}{$\begin{array}{l}\text { Lead } \\
(\mu \mathrm{g} / 1)\end{array}$} & average & 4.95 & 1.21 & 11.6 & 1.0 & $<2.0$ \\
\hline & $\max / \min$ & 14.0/N.D. & 2.3/N.D. & $20.5 / 2.2$ & $1.3 /$ N.D. & N.D. \\
\hline \multirow{2}{*}{$\begin{array}{l}\text { Mercury } \\
(\mu \mathrm{g} / \mathrm{l})\end{array}$} & average & $<0.1$ & $<2.0$ & $<0.1$ & $<0.2$ & $<0.2$ \\
\hline & max/min & N.D. & N.D. & N.D. & N.D. & N.D. \\
\hline \multirow{2}{*}{$\begin{array}{l}\text { Selenium } \\
(\mu \mathrm{g} / \mathrm{l})\end{array}$} & average & 1.74 & $<2.5$ & $<2.5$ & $<3.0$ & $<3.0$ \\
\hline & $\mathrm{max} / \mathrm{min}$ & 2.5/N.D. & N.D. & N.D. & N.D. & N.D. \\
\hline \multirow{2}{*}{$\begin{array}{l}\text { Silver } \\
(\mu g / l)\end{array}$} & average & 2.83 & 1.86 & 1.44 & 1.01 & 2.13 \\
\hline & $\max / \min$ & $4.81 / 1.40$ & 2.2/N.D. & 2.0/N.D. & 2.2/N.D. & 6.1/N.D. \\
\hline
\end{tabular}

(a) Location sampled once during 1995; therefore no maximum or minimum reported

Only one sampling event for 1997

Note: $1 \mathrm{pCi} / \mathrm{l}=0.037 \mathrm{~Bq} / 1$ 
Monitoring wells MW-1036, MW-1037, and MW-1040 had levels that exceeded baseline for sulfate during 1997. These increases reflect a regional sulfate increase in the quarry vicinity and are not believed to be due to contamination.

Chloride baseline concentrations were exceeded in samples collected from monitoring wells MW-1035, and MW-1036. The sources of these excursions are unknown, but it is unlikely that the water treatment facility is contributing to the chloride concentrations because one of the wells, MW-1035, is hydraulically upgradient from the facility. Monitoring wells MW-1037 and MW-1041 do not exceed baseline and are located closer to the treatment facility than MW-1035. A potential source of chloride is the deicing agent applied to Missouri State Route 94, which is routed along the northern perimeter upgradient of the quarry water treatment facility.

Metals concentrations exceeded baselines in three of the detection monitoring wells. Chromium levels approximately exceeded baseline in well MW-1037 and lead baseline was exceeded in wells MW-1035 and MW-1037 during this period. A potential source of the elevated metals concentration is the stainless steel casings and screens used in the construction of the detection wells. Chromium and lead can be leached from stainless steel. It is possible that such a phenomenon occurred due to the use of salts for deicing, or diluted hydrochloric acid, which was used to decontaminate remediation equipment. Either salts or acid can corrode steel.

The remainder of the monitoring parameters remained within baseline for each well. No detectable concentrations of nitroaromatic compounds, PCBs, polycyclic (or polynuclear) aromatic hydrocarbons, or pesticides were reported for 1997.

\subsubsection{Disposal Cell Groundwater Monitoring}

Monitoring wells MW-2045 through MW-2048 installed during 1996, and previously existing well MW-2032, were sampled quarterly during 1997. These disposal cell detection monitoring wells were sampled quarterly during 1997 to provide baseline data for disposal cell detection monitoring scheduled to begin in mid-1997. Statistical evaluations of baseline data will be used for comparisons to detection monitoring analytical results. These values will be reported in subsequent annual site environmental reports. 


\section{BIOLOGICAL MONITORING PROGRAM}

\subsection{Biological Program Highlights}

- The U.S. Department of Energy (DOE) has begun monitoring the establishment of wetlands created as mitigation for disturbance of wetland habitat at the Weldon Spring Site Remedial Action Project (WSSRAP) Borrow Area (see Section 9.9.2).

\subsection{Program Description}

Many of the biological sampling activities directed by DOE Orders 5400.1 and 5400.5 such as preoperational monitoring, effluent monitoring, and environmental surveillance are used to support the National Environmental Policy Act (NEPA) and Comprehensive Environmental Response, Compensation and Liability Act (CERCLA) biological monitoring program and may include the collection and analysis of water, soil, foodstuffs, and biota samples.

Activities for the biological monitoring program are selected from the results of pathway analyses. Exposure pathways identified for human and ecological receptors are identified in Section 2.1 of the Environmental Monitoring Plan (Ref. 42). Complete pathways are those that show a link between one or more contaminant sources, through one or more environmental transport processes, to a human or ecological exposure point. These exposure pathways are used to direct biological sampling activities and determine the type of data that need to be gathered, documented, and reported.

Results of biological monitoring also provide data for the human ingestion pathways and dose calculations to native aquatic organisms. The remaining pathways are monitored to support biological risk assessment studies and compliance with environmental surveillance requirements.

\subsection{Applicable Standards}

DOE Order 5400.5 addresses the protection of native aquatic organisms from the potential bioaccumulation of radionuclides. The Order states that the dose absorbed by such organisms shall not exceed $1 \mathrm{rad}$ per day from exposure to the radioactive material in liquid wastes discharged to natural waterways.

The biological monitoring program provides supporting data on the possible ingestion of biota by humans for the dose estimates in Section 5. These calculations were based on the guideline from DOE Order 5400.5 stating that members of the public should not be exposed to radiation sources as a consequence of all routine DOE activities in any one year that could cause an annual effective dose equivalent greater than $100 \mathrm{mrem}(1 \mathrm{mSv})$. 


\subsection{Aquatic Monitoring}

Biota are primarily exposed to radionuclides and other contaminants of concern at the Weldon Spring site by aquatic pathways. Contaminated surface water runoff from the site to offsite lakes and streams provides the main route of exposure to biota. Studies have been conducted to determine the uptake of contaminants on biota at on-site and off-site properties. Uranium is the main contaminant monitored in off-site surface water.

\subsubsection{Fish Monitoring}

The Environmental Monitoring Plan (Ref. 42) requires that sunfish samples from Busch Lake 35 be collected every other year or if annual average uranium concentrations in the lake waters are found to be statistically higher than the average concentration found in previous years. No fish were scheduled for collection during 1997. The next scheduled year for collection is 1998. Busch Lake 33 will be used as a background location. Sampling locations are shown on Figure 9-1.

\subsubsection{Wetland Monitoring}

As mitigation for the disturbance of approximately 2.2 acres of wetland habitat at the Borrow Area, the DOE has partially funded the construction of a 57 acre wetland complex. These wetlands are located within the August A. Busch Memorial Conservation Area, northeast of Lake 33.

In accordance with the Wetland Project Plan for COE Permit Application (Ref. 19), the $\mathrm{DOE}$ is responsible for establishing five acres of replacement wetlands. Monitoring the establishment of these replacement wetlands has begun and will continue through calendar year 1999. The monitoring includes the collection of hydrological data (water depth, duration, extent, and saturation) and biological data (vegetation, avifauna, and herpetafauna) from the constructed wetlands. Results of the monitoring conducted in 1997 indicate that the site is highly suitable for development of a sustainable wetland. Further discussion and results can be found in the 1997 Wetlands Monitoring Report for the Weldon Spring Site Remedial Action Project (Ref. 77).

\subsection{Terrestrial Monitoring}

The Environmental Monitoring Plan (Ref. 42) stipulated that monitoring of terrestrial foodstuffs would be conducted only if annual average air monitoring results indicate above background concentrations of radionuclides at critical receptor sites. Since annual air monitoring results did not show above background air monitoring results at these sites, foodstuff sampling did not take place in 1997. 


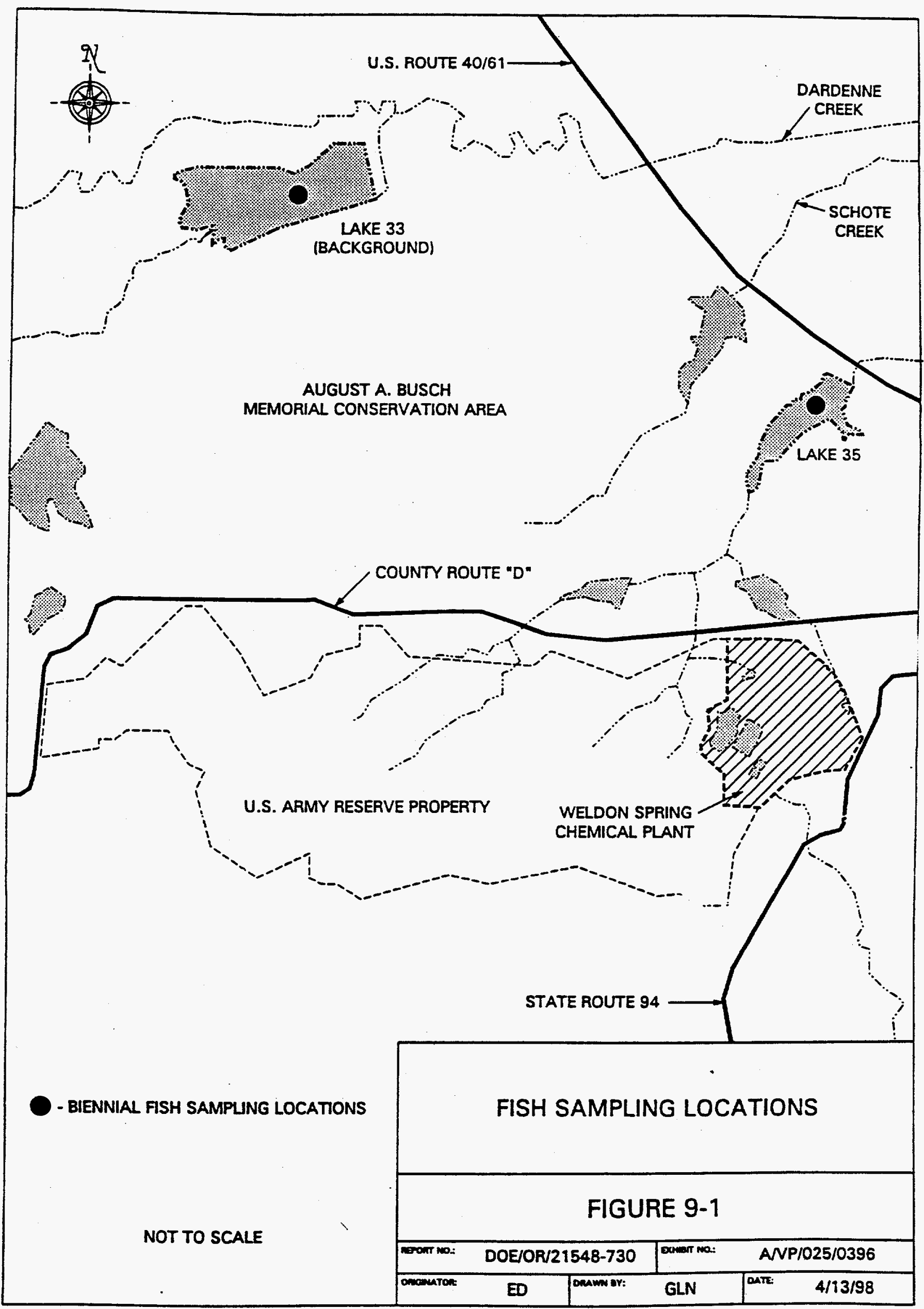




\section{ENVIRONMENTAL QUALITY ASSURANCE PROGRAM INFORMATION}

\subsection{Quality Assurance Highlights}

- Average relative percent differences calculated for groundwater, surface water, National Pollutant Discharge Elimination System (NPDES) samples and springs were within the $20 \%$ criterion recommended by the Contract Laboratory Program (CLP).

- The data validation program accepted $99.4 \%$ of the data selected for validation qualifying in 1997.

\subsection{Program Overview}

The environmental quality assurance program includes management of the quality assurance and quality control programs, plans, and procedures governing environmental monitoring activities at the Weldon Spring Site Remedial Action Project (WSSRAP) and at the subcontracted off-site laboratories. This section discusses the environmental monitoring standards at the WSSRAP and the goals for these programs, plans, and procedures.

The environmental quality assurance program provides the WSSRAP with reliable, accurate, and precise monitoring data. The program furnishes guidance and directives to detect and prevent quality problems from the time a sample is collected until the associated data are evaluated and utilized. Key elements in achieving the goals of this program are compliance with the quality assurance program and environmental quality assurance program procedures; personnel training; compliance assessments; use of quality control samples; complete documentation of field activities and laboratory analyses; and review of data documentation for precision, accuracy, and completeness.

\subsubsection{Quality Assurance Program}

The Project Management Contractor Quality Assurance Program (QAP) (Ref. 22) establishes the quality assurance program for activities performed by the Project Management Contractor (PMC). The QAP requires compliance with the criteria of DOE Order 5700.6C.

\subsubsection{Environmental Quality Assurance Project Plan}

The quality assurance requirements for WSSRAP environmental data operations are addressed in the WSSRAP Environmental Quality Assurance Project Plan (EQAPjP) (Ref. 44). The EQAPjP outlines the appropriate requirements of U.S. Environmental Protection Agency 
(EPA) QA/R-5 (Ref. 65) for characterization and routine monitoring at the WSSRAP. The EQAPjP does not supersede the QAP, but rather expands on the specific requirements of environmental monitoring and characterization activities.

The primary purpose of this document is to specify the quality assurance requirements for environmental data operations of the WSSRAP. The EQAPjP is also supported by standard operating procedures (SOPs), the Sample Management Guide (Ref. 61), the Environmental Safety and Health Plan (Ref. 45), the Environmental Monitoring Plan (EMP) (Ref. 42), and sampling plans written for specific environmental sampling tasks.

\subsubsection{Sample Management Guide}

The Sample Management Guide (SMG) (Ref. 61) summarizes SOPs and data quality requirements for collecting and analyzing environmental data. The SMG describes administrative procedures for managing environmental data and governs sampling plan preparation, data verification and validation, database administration, and data archiving. Guidance on developing data quality objectives for specific investigations is also detailed. The SMG details the specific requirements of the EQAPjP.

\subsubsection{Environmental Monitoring and Quality Assurance Standard Operating Procedures}

SOPs have been developed for routine activities at the WSSRAP. Environmental monitoring SOPs are generally administered by the Environmental Safety and Health (ES\&H) Department, and Quality Assurance SOPs are administered by the Project Quality Department. These two departments are responsible for most SOPs used to administer the environmental quality assurance program described in this section. Controlled copies of SOPs are maintained in accordance with the document control requirements of the Project Management Contractor Quality Assurance Program (Ref. 22).

\subsubsection{Evaluation and Presentation of Data}

Analytical data are received from subcontracted analytical laboratories. Uncensored data have been used in reporting and calculations for this site environmental report where available. Uncensored data are those data that do not represent a ND (nondetect) and instead report instrument responses that quantitate to values below the reported detection limit. These types of data are designated by parentheses around the data value, for example "(1.17)". If uncensored data were not available, nondetect data were used in calculations of averages at a value of onehalf the detection limit (DL/2). The EPA recommends the use of the DL/2 value for statistical manipulation of data when the percentage of nondetects in the data set is small and uncensored data are not available (Ref. 46). 


\subsubsection{Independent Assessments and Appraisals}

The environmental programs are assessed by the Project Quality Department. They evaluate compliance by performing surveillances and independent assessments of the environmental programs and generate assessment reports to track deficiencies and corrective actions.

\subsubsection{Subcontracted Off-Site Laboratories Programs}

Subcontracted off-site laboratories that performed analyses used for the preparation of this report use Contract Laboratory Program (CLP) methodologies when applicable. For certain analyses (such as radiochemical and wet chemistry) the laboratories are using EPA 600 (drinking water), EPA 900 (radiochemical analysis of drinking water), or methods that are reviewed and approved by the Project Management Contractor (PMC) prior to analysis of each sample. Each of the subcontracted off-site laboratories has submitted a site-specific Quality Assurance Project Plan (QAPjP) to the WSSRAP and controlled copies of their standard operating procedures. The QAPjPs and SOPs are reviewed and approved by the PMC before any samples are shipped to the laboratory. Changes to the standard analytical protocols or methodology are documented in the controlled SOPs. All of the laboratories currently being used by the WSSRAP have had a preliminary assessment of their facilities to make sure that they have the capability to perform work according to the specifications of their contracts. Quality assurance assessments are performed routinely to inspect the laboratory facilities and operations, to ensure that the laboratories are performing analyses as specified in their contracts, and to check that WSSRAP data documentation and records are being properly maintained.

\subsection{Applicable Standards}

Applicable standards for environmental quality assurance include: (1) use of the appropriate analytical and field measurement methodologies; (2) collection and evaluation of quality control samples; (3) accuracy, precision, and completeness evaluations; and (4) preservation and security of all applicable documents and records pertinent to the environmental monitoring programs.

\subsubsection{Analytical and Field Measurement Methodologies}

Analytical and field measurement methodologies used at the WSSRAP comply with applicable standards required by the DOE, EPA, and the American Public Health Association. Analytical methodologies used by subcontracted laboratories for environmental monitoring follow the EPA CLP requirements (metal and organic methodologies) and the EPA drinking water and radiochemical methodologies or methods that are reviewed and approved by the PMC prior to 
analysis of each sample. Field measurement methodologies typically follow the American Public Health Association Standard Methodologies for the Examination of Water and Wastewater (Ref. 47).

\subsubsection{Quality Control Samples}

Quality control samples for environmental monitoring are collected in accordance with WSSRAP SOPs that specify the frequencies of quality control sample collection. Quality control samples are taken in accordance with guidelines in the EPA CLP (Ref. 29).

Descriptions of the QC samples collected at the WSSRAP are detailed in Table 10-1.

\subsubsection{Accuracy, Precision, and Completeness}

At a minimum, the WSSRAP Data Validation Group determines the analytical accuracy, precision, and completeness of $10 \%$ of the environmental data collected. Data validation is required under DOE Order 5400.1.

\subsubsection{Preservation and Security of Documents and Records}

Requirements for preservation and security of documents and records are specified in DOE Order 5700.6C. All documents pertinent to environmental monitoring are preserved and secured by the departments that produce them.

\subsection{Quality Assurance Sample Results}

The quality assurance program is assessed by analyzing quality control sample results and comparing them to actual samples using the following methodology.

\subsubsection{Duplicate Results Evaluation}

Two kinds of duplicate analyses were evaluated in 1997, matrix duplicates and secondary duplicates. The matrix duplicate analyses were performed at subcontracted laboratories from aliquots of original samples collected at the Weldon Spring site. A secondary duplicate is an additional aliquot of the original sample split by the WSSRAP and placed into a separate container and sent to a secondary laboratory. Matrix duplicates were used to assess the precision of analyses and also to aid in evaluating the homogeneity of samples or analytical interferences of sample matrixes. 
Table 10-1 QC Sample Description

\begin{tabular}{|c|c|}
\hline TYPE OF QC SAMPLE & DESCRIPTION \\
\hline Water Blank (WB) & $\begin{array}{l}\text { Monitors the purity of distilled water used for field blanks and decontamination of } \\
\text { sampling equipment. Water blanks are collected directly from the distilled water } \\
\text { reservoir in the WSSRAP laboratory. }\end{array}$ \\
\hline Field Blank (FB) & $\begin{array}{l}\text { Monitors potential contaminants, such as dust or volatile compounds, that may be } \\
\text { introduced at the site of sample collection. Field blanks are collected in the field at } \\
\text { the same time of sample collection activities. }\end{array}$ \\
\hline Equipment Blank (EB) & $\begin{array}{l}\text { Monitors the effectiveness of decontamination procedures used on non-dedicated } \\
\text { sampling equipment. Equipment blanks include rinsate and filter blanks. }\end{array}$ \\
\hline Trip Blank (TB) & $\begin{array}{l}\text { Monitors volatile organic compounds that may be introduced during transportation } \\
\text { or handling at the laboratory. Trip blanks shall be collected in the WSSRAP } \\
\text { laboratory with prepurged distilled water. }\end{array}$ \\
\hline Field Replicate (FR) & $\begin{array}{l}\text { Monitors field conditions that may affect the reproducibility of samples collected } \\
\text { from a given location. Field replicates are collected in the field at the same location. }\end{array}$ \\
\hline Blind Duplicate & $\begin{array}{l}\text { A duplicate that provides an unbiased measure of laboratory precision. Blind } \\
\text { duplicates are additional aliquots of the routine sample taken in the field and given } \\
\text { an altered identification code to conceal the samples identity from the laboratory. }\end{array}$ \\
\hline Matrix Spike* (MS) & $\begin{array}{l}\text { Assesses matrix and accuracy of laboratory measurements for a given matrix type. } \\
\text { The results of this analysis and the routine sample are used to compute the percent } \\
\text { recovery for each parameter. }\end{array}$ \\
\hline Matrix Duplicate $(\mathrm{DU})$ & $\begin{array}{l}\text { Assesses matrix and precision of laboratory measurements for inorganic } \\
\text { parameters in a given matrix type. The results of the matrix duplicate and the } \\
\text { routine sample are used to compute the relative percent difference for each } \\
\text { parameter. }\end{array}$ \\
\hline Matrix Spike Duplicate* (MD) & $\begin{array}{l}\text { Assess matrix and precision of laboratory measurements for organic compounds. } \\
\text { The matrix spike duplicates is spiked in the same manner as the matrix spike } \\
\text { sample. The results of the matrix spike and matrix spike duplicate are used to } \\
\text { determine the relative percent difference for organic parameters. }\end{array}$ \\
\hline Secondary Duplicate (SD) & $\begin{array}{l}\text { A duplicate that compares the primary laboratory with a secondary laboratory, } \\
\text { providing an additional check on the performance of the primary laboratory. The } \\
\text { secondary duplicate is an additional aliquot of the routine sample that is sent to a } \\
\text { secondary laboratory. }\end{array}$ \\
\hline
\end{tabular}

* A laboratory sample is split from the parent sample.

Generally, matrix duplicate samples were analyzed for the same parameters as the original samples at the rate of approximately one for every 20 samples. Secondary duplicate samples were collected in accordance with Procedure ES\&H 4.1.4, which states that secondary duplicates shall be collected on a monthly basis. Typically, duplicate samples were analyzed for more common parameters e.g., uranium, inorganic anions, and metals.

When matrix and secondary duplicate samples were available, the average relative percent difference was calculated. This difference represents an estimate of precision. The equation used (as specified in the USEPA Contract Laboratory Program, Inorganic Scope of Work, [Ref. 29]) was: 
$\mathrm{RPD}=(\mathrm{S}-\mathrm{D}) /((\mathrm{S}+\mathrm{D}) / 2) \times 100$

where $S=$ the normal sample

$\mathrm{D}=$ the duplicate analysis

The relative percent difference was calculated only for samples whose analytical results exceeded five times the detection limit.

Table 10-2 summarizes the data of calculated relative percent differences for groundwater (including springs) and surface water (including National Pollutant Discharge Elimination System [NPDES]) samples. Both the matrix duplicates and the secondary duplicates are summarized together. Parameters that were not commonly analyzed for and/or were not contaminants of concern were not evaluated.

Table 10-2 Summary of Calculated Relative Percent Differences

\begin{tabular}{|l|c|c|c|c|}
\hline \multicolumn{1}{|c|}{ PARAMETER } & N(a) & AVG. RPD & MIN. RPD & MAX. RPD \\
\hline Arsenic & 8 & 5.89 & 0.89 & 12.42 \\
\hline Barium & 31 & 6.56 & 0.00 & 28.74 \\
\hline Calcium & 7 & 7.18 & 1.77 & 12.00 \\
\hline Chemical oxygen Demand & 3 & 11.04 & 2.96 & 16.57 \\
\hline Chloride & 21 & 5.80 & 0.10 & 29.27 \\
\hline Chromium & 4 & 14.37 & 2.74 & 25.46 \\
\hline Fluoride & 11 & 5.47 & 0.00 & 28.57 \\
\hline Lead & 3 & 6.82 & 1.85 & 15.16 \\
\hline Magnesium & 7 & 7.68 & 1.82 & 14.70 \\
\hline Mercury & 3 & 2.36 & 0.00 & 4.08 \\
\hline Nitrate-N & 34 & 4.74 & 0.00 & 27.68 \\
\hline Selenium & 8 & 7.24 & 0.00 & 28.57 \\
\hline Sulfate & 38 & 4.99 & 0.00 & 17.23 \\
\hline Total Dissolved Solids & 7 & 1.56 & 0.29 & 3.86 \\
\hline Total Organic Carbon & 9 & 8.79 & 0.00 & 48.85 \\
\hline Total Suspended Solids & 9 & 6.92 & 0.00 & 17.24 \\
\hline Uranium, Total & 38 & 5.50 & 0.00 & 37.39 \\
\hline
\end{tabular}

(a) Data Population

The results in Table 10-2 demonstrate that all average relative percent differences calculated were within the $20 \%$ criterion as recommended in the CLP (Ref. 29 and 46). As a result, duplicate sample analyses in 1997 were of acceptable quality.

\subsubsection{Blank Sample Results Evaluation}

Various types of blanks are collected by the WSSRAP to assess the conditions and/or contaminants that may be present during sample collection and transportation. These conditions 
and contaminants are monitored by collecting samples to ensure routine samples are not being contaminated. Blank samples evaluate the:

- Environmental conditions under which the samples (i.e., volatile analyses) were shipped (trip blanks).

- Ambient conditions in the field that may affect a sample during collection (field/trip blanks).

- Effectiveness of the decontamination procedure for sampling equipment used to collect samples (equipment blanks).

- Quality of water used to decontaminate sampling equipment and/or assess the ambient conditions (distilled water blanks).

- Presence or absence of contamination potentially introduced through sample preservation and/or sample containers.

Sections 10.4.2.1 through 10.4.2.4 discuss the sample blank analyses and the summary of analytical results that were above the analytical detection limits.

\subsubsection{Trip Blank Evaluation}

Trip blanks are collected to assess the impact of sample collection and shipment on groundwater and surface water samples analyzed for volatile organic compounds. Trip blanks are sent to the laboratory with each shipment of volatile organic samples.

In 1997, 98 trip blanks were analyzed for volatile organic compounds. Detections for acetone were found in four blanks, methylene chloride in two blanks, toluene in one blank and trichloroethene in one blank. All environmental samples associated with the eight blank detections listed above were evaluated. Four samples were potentially impacted, two samples detected acetone, and two samples detected methylene chloride. All other samples evaluated did not exceed the recommended CLP criterion.

\subsubsection{Field Blank Evaluation}

Field blank samples are collected at monitoring locations just prior to, or immediately after, actual samples are collected. The field blanks are collected to assess the ambient air conditions at the sample locations and are generally for the parameters of concern, such as 
uranium, anions, metals, and nitroaromatics.

In 1997, four field blanks were collected. Table 10-3 presents the ratio of detects to total number of samples collected for each parameter having results above the detection limits.

Table 10-3 Summary of Field Blank Parameter Results

\begin{tabular}{|c|c|c|}
\hline PARAMETER & $\begin{array}{c}\text { NUMBER OF DETECTS/NUMBER } \\
\text { OF ANALYSES }\end{array}$ & $\begin{array}{l}\text { EVALUATION AND SUMMARY OF } \\
\text { DETECTS }\end{array}$ \\
\hline Arsenic & 1 out of $4(25 \%)$ & 1 of $1(100 \%)=D L$ \\
\hline Barium & 1 out of $4(25 \%)$ & 1 of $1(100 \%)<3 \times D L$ \\
\hline Cadmium & 0 out of $2(0 \%)$ & N/A \\
\hline Chloride & Dout of $2(0 \%)$ & N/A \\
\hline Chromium & 0 out $1(0 \%)$ & N/A \\
\hline Fluoride & 0 out of $1(0 \%)$ & N/A \\
\hline Gross Alpha & 0 out of $2(0 \%)$ & N/A \\
\hline Gross Beta & 0 out of $2(0 \%)$ & N/A \\
\hline Lead & Oout of $2(0 \%)$ & N/A \\
\hline Mercury & 0 out of $2(0 \%)$ & N/A \\
\hline Nitrate as $\mathrm{N}$ & 2 out of $2(100 \%)$ & 1 of $2(50 \%)<4 \times D L$ \\
\hline & & 1 of $2(50 \%)>5 \times D L$ \\
\hline Nitroaromatics & 0 out of $3(100 \%)$ & N/A \\
\hline Radium-228 & 1 out of $1(100 \%)$ & 1 of $1(100 \%)>5 \times D L$ \\
\hline Radium-226 & 1 out of $1(100 \%)$ & 1 of $1(100 \%)>5 \times D L$ \\
\hline Selenium & 0 out of $2(0 \%)$ & N/A \\
\hline Silver & 1 out of $2(50 \%)$ & 1 of $1(100 \%)<2 \times D L$ \\
\hline Sulfate & 0 out of $4(0 \%)$ & N/A \\
\hline Thorium-228 & 1 out of $1(100 \%)$ & 1 of $1(100 \%)<2 \times D L$ \\
\hline Thorium-230 & 0 out of $1(0 \%)$ & N/A \\
\hline Thorium-232 & 0 out of $1(0 \%)$ & N/A \\
\hline Uranium-234 & 1 out of $1(100 \%)$ & 1 of $1(100 \%)<2 \times D L$ \\
\hline Uranium-235 & 0 out of $1(0 \%)$ & N/A \\
\hline Uranium-238 & O out of $1(0 \%)$ & N/A \\
\hline Uranium, total & 0 out of $2(0 \%)$ & N/A \\
\hline Volatiles & 1 out of $3(33 \%)$ & 1 of $1(100 \%)<2 \times D L$ \\
\hline
\end{tabular}

DL Detection limit

N/A Not applicable

\subsubsection{Equipment and Bailer Blank Evaluation}

Equipment and bailer blanks are collected by rinsing decontaminated equipment and bailers with distilled water, and collecting the rinse water. This procedure is used to determine the effectiveness of the decontamination process. At the WSSRAP, most of the groundwater samples are collected from dedicated equipment, and surface water is collected by placing the sample directly into a sample container; therefore, no further discussion is presented. 


\subsubsection{Distilled Water Blank Evaluation}

Water blank samples are collected to evaluate the quality of the distilled water used to decontaminate sampling equipment and to assess whether contaminants are present in the water used for field and trip blanks. Water blank samples also serve as laboratory blanks. Generally, the water blanks were analyzed for contaminants of concern and were collected at the same time as field blanks.

In 1997,12 water blanks were collected. Table 10-4 presents the ratio of detects to the total number of samples collected for each parameter that had results above the detection limit.

Table 10-4 Summary of Distilled Water Blank Parameter Results

\begin{tabular}{|c|c|c|}
\hline PARAMETER & $\begin{array}{l}\text { NUMBER OF DETECTSINUMBER } \\
\text { OF ANALYSES }\end{array}$ & $\begin{array}{l}\text { EVALUATION AND SUMMARY OF } \\
\text { DETECTS }\end{array}$ \\
\hline Arsenic & 0 out of $12(0 \%)$ & N/A \\
\hline \multirow[t]{3}{*}{ Barium } & 5 out of $12(42 \%)$ & 1 of $5(20 \%)<2 \times D L$ \\
\hline & & 2 of $5(40 \%)<3 \times D L$ \\
\hline & & 2 of $5(40 \%)<4 \times D L$ \\
\hline Cadmium & 0 out of $12(0 \%)$ & N/A \\
\hline Chloride & 0 out of $12(0 \%)$ & N/A \\
\hline Chromium & 2 out of $12(17 \%)$ & 2 of $2(100 \%)<2 \times D L$ \\
\hline Fluoride & 0 out of $12(0 \%)$ & N/A \\
\hline Lead & 1 out of $12(8 \%)$ & 1 of $1(100 \%)<2 \times D L$ \\
\hline \multirow[t]{2}{*}{ Mercury } & 2 out of $12(17 \%)$ & 1 of $2(50 \%)<2 \times D L$ \\
\hline & & 1 of $2(50 \%)<3 \times D L$ \\
\hline \multirow[t]{4}{*}{ Nitrate as $\mathrm{N}$} & 12 out of $12(100 \%)$ & 1 of $12(8 \%)=D L$ \\
\hline & & 1 of $12(8 \%)<3 \times D L$ \\
\hline & & 1 of $12(8 \%)<4 \times D L$ \\
\hline & & 9 of $12(75 \%)>5 \times D L$ \\
\hline Nitroaromatics & 0 out of $12(0 \%)$ & N/A \\
\hline PAHs & 1 out of $9(11 \%)$ & 1 of $1(100 \%)=D L$ \\
\hline PCBs & 0 out of $11(0 \%)$ & N/A \\
\hline \multirow[t]{4}{*}{ Radium-226 } & 6 out of $12(50 \%)$ & 3 of $6(50 \%)<2 \times D L$ \\
\hline & & 1 of $6(17 \%)<3 \times D L$ \\
\hline & & 1 of $6(17 \%)<4 \times D L$ \\
\hline & & 1 of $6(17 \%)>5 \times D L$ \\
\hline \multirow[t]{2}{*}{ Radium-228 } & 4 out of $12(33 \%)$ & 3 of $4(75 \%)<2 \times D L$ \\
\hline & & 1 of $4(25 \%)<4 \times D L$ \\
\hline Selenium & 0 out of $12(0 \%)$ & N/A \\
\hline Sulfate & 1 out of $12(8 \%)$ & 1 of $1(100 \%)<2 \times D L$ \\
\hline Thorium-228 & 1 out of $12(8 \%)$ & 1 of $1(100 \%)<2 \times D L$ \\
\hline \multirow[t]{3}{*}{ Th-230 } & 10 out of $12(83 \%)$ & 6 of $10(60 \%)<2 \times D L$ \\
\hline & & 3 of $10(30 \%)<4 \times D L$ \\
\hline & & 1 of $10(10 \%)>5 \times D L$ \\
\hline Thorium-232 & 1 out of $12(8 \%)$ & 1 of $1(100 \%)<2 \times D L$ \\
\hline Uranium-234 & 2 out of $5(40 \%)$ & 2 of $2(100 \%)<2 \times D L$ \\
\hline Uranium-235 & 0 out of $5(0 \%)$ & N/A \\
\hline Uranium-238 & 0 out of $5(0 \%)$ & N/A \\
\hline
\end{tabular}


Table 10-4_Summary of Distilled Water Blank Parameter Results

\begin{tabular}{|l|c|c|}
\hline \multicolumn{1}{|c|}{ PARAMETER } & $\begin{array}{c}\text { NUMBER OF DETECTS/NUMBER } \\
\text { OF ANALYSES }\end{array}$ & $\begin{array}{c}\text { EVALUATION AND SUMMARY OF } \\
\text { DETECTS }\end{array}$ \\
\hline Uranium, Total & 3 out of $12(25 \%)$ & 1 of $3(33 \%)<2 \times D L$ \\
\hline & & 2 of $3(67 \%)>5 \times D L$ \\
\hline Volatiles & 2 out of $12(17 \%)$ & 2 of $2(100 \%)<5 \times D L$ \\
\hline
\end{tabular}

DL Detection limit

N/A Not Applicable

\subsection{Data Validation Program Summary}

Data validation programs at the WSSRAP involve reviewing and qualifying at least $10 \%$ of the data collected during a calendar year. The data points represent the number of parameters analyzed (e.g., toluene), not the number of physical analyses performed (e.g., volatile organics analyses).

Table 10-5 identifies the number of quarterly and total data points that were selected for data validation, and indicates the percentage of those selected that were complete. Data points presented in this table include all sample types.

Table 10-5 WSSRAP Validation Summary for Calendar Year 1997

\begin{tabular}{|c|c|c|c|c|c|}
\hline $\begin{array}{c}\text { CALENDAR } \\
\text { QUARTER }\end{array}$ & $\begin{array}{c}\text { NO. OF DATA } \\
\text { POINTS } \\
\text { COLLECTED }\end{array}$ & $\begin{array}{l}\text { NO. OF DATA } \\
\text { POINTS } \\
\text { SELECTED FOR } \\
\text { VALIDATION }\end{array}$ & $\begin{array}{l}\text { PERCENT } \\
\text { SELECTED }\end{array}$ & $\begin{array}{l}\text { NO. OF DATA } \\
\text { POINTS } \\
\text { VALIDATED }\end{array}$ & $\begin{array}{l}\text { PERCENT } \\
\text { VALIDATED }\end{array}$ \\
\hline Quarter 1 & 19,441 & 2,181 & $11.2 \%$ & 2,181 & $100.0 \%$ \\
\hline Quarter 2 & 12,959 & 1,221 & $9.4 \%$ & 1,221 & $100.0 \%$ \\
\hline Quarter 3 & 19,720 & 2,572 & $13.0 \%$ & 2,572 & $100.0 \%$ \\
\hline Quarter 4 & 41,088 & 4,099 & $10.0 \%$ & 4,099 & $100.0 \%$ \\
\hline 1997 Total & 94,208 & 10,073 & $10.8 \%$ & 10,073 & $100.0 \%$ \\
\hline
\end{tabular}

Reflects all validatable data for the calendar year.

Table 10-6 identifies validation qualifiers assigned to the selected data points as a result of data validation. The WSSRAP validation technical review was performed in accordance with the U.S. EPA Contract Laboratory Program Data Statement of Work for Inorganics Analysis (Ref. 62), the U.S. EPA Contract Laboratory Program Statement of Work for Organic Analysis (Ref. 63), and the Laboratory Data Validation Guidelines for Evaluating Radionuclide Analysis (Ref. 64). For calendar year 1997, 100.0\% of data validation has been completed. Data points presented in this table include groundwater, surface water, spring and seep water, and NPDES samples only. 
Table 10-6 WSSRAP Validation Summary for Calendar Year 1997

\begin{tabular}{|c|c|c|c|c|c|c|c|c|c|}
\hline \multicolumn{10}{|c|}{ NO. OF DATA POINTS } \\
\hline & ANIONS & METALS & MISC. & $\begin{array}{c}\text { NITRO- } \\
\text { AROMATICS } \\
\end{array}$ & $\begin{array}{c}\text { PESTICIDES } \\
\text { /PCBS }\end{array}$ & $\begin{array}{c}\text { RADIO- } \\
\text { CHEMICAL } \\
\end{array}$ & $\begin{array}{c}\text { SEMI- } \\
\text { VOLATILES }\end{array}$ & VOLATILES & TOTAL \\
\hline Accepted & 92 & 447 & 80 & 4 & 104 & 170 & 251 & 1,796 & 2,944 \\
\hline Rejected & 0 & 2 & 0 & 0 & 3 & 3 & 0 & 9 & 17 \\
\hline On Hold & 0 & 0 & 0 & 0 & 0 & 1 & 0 & 0 & 0 \\
\hline Not Validatable & 0 & 0 & 0 & 0 & 0 & 1 & 0 & 0 & 1 \\
\hline Pending & 0 & 0 & 0 & 0 & 0 & 0 & 0 & 0 & 0 \\
\hline Total & 92 & 449 & 80 & 4 & 107 & 175 & 251 & 1,805 & 2,962 \\
\hline \multicolumn{10}{|c|}{ PERCENTAGES } \\
\hline Accepted & $100.0 \%$ & $99.6 \%$ & $100.0 \%$ & $100.0 \%$ & $97.2 \%$ & $97.7 \%$ & $100.0 \%$ & $99.5 \%$ & $99.4 \%$ \\
\hline Rejected & $0.0 \%$ & $0.4 \%$ & $0.0 \%$ & $0.0 \%$ & $2.8 \%$ & $1.7 \%$ & $0.0 \%$ & $0.5 \%$ & $0.6 \%$ \\
\hline On Hold & $0.0 \%$ & $0.0 \%$ & $0.0 \%$ & $0.0 \%$ & $0.0 \%$ & $0.0 \%$ & $0.0 \%$ & $0.0 \%$ & $0.0 \%$ \\
\hline Not Valdiatable & $0.0 \%$ & $0.0 \%$ & $0.0 \%$ & $0.0 \%$ & $0.0 \%$ & $0.6 \%$ & $0.0 \%$ & $0.0 \%$ & $0.0 \%$ \\
\hline Pending & $0.0 \%$ & $0.0 \%$ & $0.0 \%$ & $0.0 \%$ & $0.0 \%$ & $0.0 \%$ & $0.0 \%$ & $0.0 \%$ & $0.0 \%$ \\
\hline Total & $100.0 \%$ & $100.0 \%$ & $100.0 \%$ & $100.0 \%$ & $100.0 \%$ & $100.0 \%$ & $100.0 \%$ & $100.0 \%$ & $100.0 \%$ \\
\hline
\end{tabular}

Reflects only validatable groundwater, surface water, spring and seep, and NPDES data for the calendar year. 
Table 10-7 identifies the average accuracy and precision for anion, metals, nitroaromatic, radiochemical, and miscellaneous parameters. The accuracy values are based on the percent recoveries of the laboratory control samples, and the precision values are based on the relative percent difference between duplicates. The data population size associated with each accuracy and precision value is listed as "N." Data points presented in this table include groundwater, surface water, spring and seep, and NPDES samples only. 
Table 10-7 Laboratory Accuracy and Precision Summary for Calendar Year 1997

\begin{tabular}{|c|c|c|c|c|c|c|c|}
\hline \multirow[b]{2}{*}{ PARAMETER } & \multirow[b]{2}{*}{$N$} & \multicolumn{3}{|c|}{ LABORATORY ACCURACY } & \multicolumn{3}{|c|}{ LABORATORY PRECISION } \\
\hline & & AVERAGE & MINIMUM & MAXIMUM & AVERAGE & MINIMUM & MAXIMUM \\
\hline \multicolumn{8}{|l|}{ IONS } \\
\hline Chloride & 16 & 99.1 & 94.0 & 109.3 & 0.9 & 0.0 & 3.7 \\
\hline Fluoride & 14 & 99.4 & 94.6 & 103.0 & 2.1 & 0.0 & 6.5 \\
\hline Nitrate-N & 24 & 101.8 & 94.6 & 109.0 & 4.1 & 0.3 & 8.6 \\
\hline Sulfate & 34 & 100.2 & 94.0 & $108 / 7$ & 0.5 & 0.0 & 1.4 \\
\hline \multicolumn{8}{|l|}{ METALS } \\
\hline Aluminum & 16 & 97.5 & 89.2 & 104.8 & 2.8 & 0.8 & 7.5 \\
\hline Antimony & 16 & 99.5 & 96.2 & 104.0 & 1.1 & 0.3 & 2.5 \\
\hline Arsenic & 30 & 99.1 & 91.3 & 108.4 & 1.2 & 0.0 & 3.8 \\
\hline Barium & 21 & 96.0 & 91.2 & 101.4 & 0.9 & 0.2 & 2.2 \\
\hline Beryllium & 16 & 97.6 & 92.2 & 101.6 & 1.4 & 0.0 & 3.1 \\
\hline Cadmium & 17 & 97.4 & 93.2 & 107.8 & 1.0 & 0.3 & 2.5 \\
\hline Calcium & 15 & 97.6 & 92.7 & 105.7 & 1.4 & 0.1 & 3.2 \\
\hline Chromium & 25 & 98.1 & 91.1 & 103.8 & 1.4 & 0.1 & 3.9 \\
\hline Cobalt & 16 & 96.5 & 91.6 & 101.7 & 1.3 & 0.2 & 2.9 \\
\hline Copper & 16 & 95.4 & 90.6 & 100.8 & 1.2 & 0.1 & 2.2 \\
\hline Iron & 16 & 101.0 & 94.3 & $106 / 9$ & 2.0 & 0.1 & 5.0 \\
\hline Lead & 25 & 99.1 & 93.2 & 104.7 & 1.3 & 0.1 & 3.5 \\
\hline Lithium & 16 & 87.6 & 81.4 & 92.3 & 0.7 & 0.3 & 1.8 \\
\hline Magnesium & 15 & 98.4 & 94.0 & 102.5 & 1.5 & 0.3 & 3.0 \\
\hline Manganese & 16 & 96.2 & 91.6 & 100.9 & 1.9 & 0.1 & 4.2 \\
\hline Mercury & 18 & 98.2 & 80.2 & 112.0 & 6.0 & 1.4 & 15.7 \\
\hline Molybdenum & 15 & 100.0 & 94.9 & 106.6 & 1.7 & 0.4 & 3.9 \\
\hline Nickel & 16 & 95.7 & 92.0 & 106.0 & 1.0 & 0.1 & 2.4 \\
\hline Potassium & 15 & 96.8 & 89.7 & 102.2 & 1.2 & 0.5 & 1.7 \\
\hline Selenium & 17 & 97.6 & 93.3 & 104.1 & 2.0 & 0.2 & 9.9 \\
\hline Silver & 17 & 97.8 & 93.4 & 104.1 & 3.1 & 0.1 & 10.9 \\
\hline Sodium & 15 & 99.8 & 92.5 & 108.0 & 2.1 & 0.0 & 5.6 \\
\hline Thallium & 24 & 97.7 & 92.5 & 103.9 & 1.5 & 0.2 & 4.6 \\
\hline Vanadium & 16 & 95.0 & 88.2 & 100.2 & 1.6 & 0.2 & 2.9 \\
\hline Zinc & 16 & 101.3 & 95.3 & 111.2 & 1.1 & 0.2 & 2.5 \\
\hline
\end{tabular}


Table 10-7 Laboratory Accuracy and Precision Summary for Calendar Year 1997 (Continued)

\begin{tabular}{|c|c|c|c|c|c|c|c|}
\hline \multirow[b]{2}{*}{ PARAMETER } & \multirow[b]{2}{*}{$N$} & \multicolumn{3}{|c|}{ LABORATORY ACCURACY } & \multicolumn{3}{|c|}{ LABORATORY PRECISION } \\
\hline & & AVERAGE & MINIMUM & MAXIMUM & AVERAGE & MINIMUM & MAXIMUM \\
\hline \multicolumn{8}{|l|}{ MISC. } \\
\hline Biochemical oxygen demand & 1 & 78.8 & 78.8 & 78.8 & 10.1 & 10.1 & 10.1 \\
\hline Chemical Oxygen demand & 7 & 96.2 & 94.9 & 97.1 & 2.7 & 0.8 & 3.9 \\
\hline Chemical Oxygen demand (COD) & 6 & 95.7 & 95.7 & 95.7 & 1.8 & 1.8 & 1.8 \\
\hline Cyanide, Total & 14 & 106.2 & 99.2 & 110.0 & 7.1 & 2.3 & 11.1 \\
\hline Total dissolved solids & 6 & 99.2 & 98.7 & 100.0 & 1.2 & 1.0 & 1.4 \\
\hline Total dissolved solids (TDS) & 5 & 110.0 & 99.0 & 112.7 & 3.9 & 1.7 & 4.5 \\
\hline Total organic carbon & 6 & 101.1 & 98.8 & 106.1 & 0.6 & 0.2 & 2.7 \\
\hline Total organic carbon (TOC) & 6 & 106.0 & 106.0 & 106.0 & 0.9 & 0.9 & 0.9 \\
\hline Total organic halides (TOX) & 6 & 109.8 & 109.8 & 109.8 & 12.1 & 12.1 & 12.1 \\
\hline Total suspended solids & 4 & 98.8 & 98.8 & 98.8 & 1.8 & 1.8 & 1.8 \\
\hline TOX & 7 & 106.4 & 99.5 & 109.8 & 1.9 & 0.1 & 3.1 \\
\hline \multicolumn{8}{|l|}{ NITROAROMATICS } \\
\hline 2,4,6-Trinitrotoluene & 1 & 79.2 & 79.2 & 79.2 & 7.6 & 7.6 & 7.6 \\
\hline \multicolumn{8}{|l|}{ RADIOCHEMICAL } \\
\hline Gross Alpha & 11 & 111.8 & 103.2 & 118.9 & 0.1 & 0.1 & 0.2 \\
\hline Radium-226 & 23 & 96.5 & 57.6 & 114.0 & 10.6 & 0.0 & 24.2 \\
\hline Radium-228 & 19 & 96.1 & 78.2 & 125.0 & 8.3 & 0.6 & 15.4 \\
\hline Thorium-228 & 5 & 102.9 & 92.3 & 105.6 & 0.3 & 0.1 & 0.3 \\
\hline Thorium-230 & 5 & 111.4 & 110.4 & 111.7 & 0.5 & 0.1 & 0.6 \\
\hline Thorium-232 & 20 & 94.7 & 87.8 & 98.9 & 5.1 & 0.1 & 12.4 \\
\hline Uranium, total & 33 & 101.2 & 93.7 & 110.3 & 1.3 & 0.0 & 6.4 \\
\hline \multicolumn{8}{|l|}{ SEMI-VOLATILES } \\
\hline Acenaphthene & 5 & 86.4 & 72.0 & 90.0 & 3.1 & 2.5 & 5.6 \\
\hline Acenaphthylene & 5 & 86.4 & 86.0 & 88.0 & 4.4 & 3.9 & 6.4 \\
\hline Anthracene & 5 & 87.4 & 86.0 & 93.0 & 4.9 & 4.8 & 5.4 \\
\hline Benzo(a)anthracene & 5 & 91.8 & 90.0 & 99.0 & 3.7 & 2.7 & 3.9 \\
\hline Benzo(a)pyrene & 5 & 89.2 & 87.0 & 98.0 & 3.4 & 2.0 & 3.8 \\
\hline Benzo(b)fluoranthene & 5 & 96.0 & 94.0 & 104.0 & 1.7 & 0.6 & 2.0 \\
\hline Benzo(g,h, $)$ perylene & 5 & 77.0 & 69.0 & 79.0 & 5.3 & 0.8 & 23.3 \\
\hline Benzo(k)fluoranthene & 5 & 98.6 & 88.0 & 96.0 & 2.0 & 0.2 & 2.5 \\
\hline Chrysene & 5 & 92.4 & 91.0 & 98.0 & 3.1 & 2.5 & 3.3 \\
\hline
\end{tabular}


Table 10-7 Laboratory Accuracy and Precision Summary for Calendar Year 1997 (Continued)

\begin{tabular}{|c|c|c|c|c|c|c|c|}
\hline & & \multicolumn{3}{|c|}{ LABORATORY ACCURACY } & \multicolumn{3}{|c|}{ LABORATORY PRECISION } \\
\hline PARAMETER & $\mathbf{N}$ & AVERAGE & MINIMUM & MAXIMUM & AVERAGE & MINIMUM & MAXIMUM \\
\hline Dibenzo(a,h)anthracene & 5 & 60.4 & 54.0 & 62.0 & 12.3 & 9.9 & 22.1 \\
\hline Fluoranthene & 5 & 98.4 & 96.0 & 108.0 & 0.1 & 0.0 & 0.1 \\
\hline Fluorene & 5 & 92.2 & 91.0 & 97.0 & 3.5 & 3.0 & 5.3 \\
\hline Indeno(1,2,3-CD)pyrene & 5 & 82.2 & 81.0 & 87.0 & 2.7 & 2.7 & 2.8 \\
\hline Naphthalene & 5 & 89.0 & 73.0 & 93.0 & 10.9 & 10.5 & 12.4 \\
\hline Phenanthrene & 5 & 92.0 & 91.0 & 96.0 & 3.0 & 2.8 & 3.0 \\
\hline Pyrene & 5 & 99.8 & 98.0 & 107.0 & 3.0 & 2.8 & 3.0 \\
\hline VOLATILES & & & & & & & \\
\hline 1,1,1-Trichloroethane & 6 & 98.5 & 90.0 & 100.6 & 4.1 & 0.0 & 5.0 \\
\hline $1,1,2,2$-Tetrachloroethane & 6 & 108.9 & 100.6 & 130.0 & 8.9 & 8.0 & 9.1 \\
\hline 1,1,2-Trichloroethane & 6 & 104.4 & 104.3 & 105.0 & 4.7 & 4.7 & 5.0 \\
\hline 1,1-Dichloroethane & 6 & 98.6 & 70.0 & 127.8 & 5.5 & 0.0 & 26.1 \\
\hline 1,1-Dichloroethene & 8 & 91.7 & 65.0 & 107.8 & 5.6 & 4.7 & 7.0 \\
\hline 1,2-Dichloroethane & 6 & 95.1 & 70.0 & 100.1 & 0.0 & 0.0 & 0.0 \\
\hline 1,2-Dichloroethene (total) & 1 & 130.0 & 130.0 & 130.0 & 0.0 & 0.0 & 0.0 \\
\hline 1,2-Dichloropropane & 6 & 104.3 & 104.1 & 105.0 & 3.9 & 0.0 & 4.7 \\
\hline 2-Butanone & 6 & 100.0 & 55.0 & 109.0 & 15.6 & 10.0 & 16.7 \\
\hline 2-Hexanone & 6 & 97.7 & 60.0 & 105.2 & 17.8 & 0.0 & 21.3 \\
\hline 4-Methyl-2-Pentanone & 6 & 111.0 & 95.0 & 114.2 & 4.4 & 4.3 & 5.0 \\
\hline Acetone & 6 & 99.3 & 45.0 & 110.1 & 18.7 & 12.0 & 20.0 \\
\hline Benzene & 8 & 100.9 & 100.0 & 101.5 & 6.6 & 0.0 & 10.5 \\
\hline Bromodichloromethane & 6 & 98.3 & 90.0 & 100.0 & 0.0 & 0.0 & 0.0 \\
\hline Bromoform & 6 & 99.0 & 97.8 & 105.0 & 4.9 & 4.9 & 5.0 \\
\hline Bromomethane & 6 & 118.0 & 102.5 & 195.0 & 7.6 & 5.1 & 20.0 \\
\hline Carbon Disulfide & 6 & 91.9 & 75.0 & 95.3 & 13.2 & 6.0 & 14.6 \\
\hline Carbon Tetrachloride & 6 & 100.1 & 90.0 & 102.1 & 5.8 & 4.9 & 10.0 \\
\hline Chlorobenzen & 8 & 100.4 & 100.0 & 100.6 & 4.9 & 4.9 & 5.0 \\
\hline Chloroethane & 6 & 134.4 & 110.3 & 255.0 & 12.8 & 4.0 & 14.6 \\
\hline Chloroform & 6 & 94.4 & 70.0 & 100.6 & 2.0 & 0.0 & 7.0 \\
\hline Chloromethane & 6 & 100.4 & 99.5 & 105.0 & 8.8 & 0.0 & 10.5 \\
\hline Cis-1,3-Dichloropropene & 6 & 98.3 & 90.0 & 99.9 & 4.1 & 0.0 & 4.9 \\
\hline Dibromochloromethane & 6 & 100.8 & 100.0 & 100.9 & 4.9 & 4.9 & 5.0 \\
\hline
\end{tabular}


Table 10-7 Laboratory Accuracy and Precision Summary for Calendar Year 1997 (Continued)

\begin{tabular}{|c|c|c|c|c|c|c|c|}
\hline & & \multicolumn{3}{|c|}{ LABORATORY ACCURACY } & \multicolumn{3}{|c|}{ LABORATORY PRECISION } \\
\hline PARAMETER & $N$ & AVERAGE & MINIMUM & MAXIMUM & AVERAGE & MINIMUM & MAXIMUM \\
\hline Ethyl Benzene & 6 & 99.4 & 99.3 & 100.0 & 8.8 & 5.0 & 9.5 \\
\hline Methylene Chloride & 6 & 114.1 & 75.0 & 127.8 & 17.4 & 0.0 & 26.1 \\
\hline Styrene & 6 & 98.7 & 95.0 & 99.4 & 4.1 & 0.0 & 4.9 \\
\hline Tetrachloroethene & 6 & 101.1 & 100.3 & 105.0 & 4.1 & 0.0 & 4.9 \\
\hline Toluene & 8 & 101.7 & 99.7 & 105.0 & 4.1 & 0.0 & 4.9 \\
\hline Trans-1,3-Dichloropropene & 6 & 98.3 & 95.0 & 98.9 & 4.9 & 4.9 & 5.0 \\
\hline Trichlorethene & 8 & 100.9 & 100.0 & 101.5 & 3.1 & 0.0 & 4.9 \\
\hline Trichloroethene (GC) & 21 & 98.9 & 92.9 & 106.0 & 3.2 & 0.7 & 10.5 \\
\hline Vinyl chloride & 6 & 97.7 & 90.0 & 99.2 & 5.1 & 5.0 & 5.1 \\
\hline Xylenes, Total & 6 & 116.9 & 101.3 & 195.0 & 5.3 & 0.0 & 6.3 \\
\hline
\end{tabular}




\section{SPECIAL STUDIES}

This section highlights significant activities and efforts at the Weldon Spring Site Remedial Action Project that support and assist in the implementation of environmental protection policies. In addition, short term environmental studies are described that support regulatory requirements not specifically covered by U.S. Department of Energy (DOE) Order 5400.1 or that were not planned in the Environmental Monitoring Plan (Ref. 42).

\subsection{Off-Site Migration of Uranium in Storm Water}

In an effort to determine the effect of site activities on the off-site migration of uranium in storm water at the three major National Pollutant Discharge Elimination System (NPDES) outfalls (NP-0002, NP-0003, NP-0005), the data for the years 1987 through 1994 were reviewed and corrected for several factors, as required, to normalize the data. The corrections were for precipitation, watershed areas, and runoff coefficients and are outlined in the Weldon Spring Site Environmental Report for Calendar Year 1994 (Ref. 66).

These data have been updated with the inclusion of 1995, 1996, and 1997 data. This recent data did not require correction. The annual mass, annual precipitation, and mass per inch of precipitation are tabulated in Table 11-1. The annual precipitation and total annual mass discharged off site through 1997 are plotted in Figure 11-1, Figure 11-2 and Figure 11-3. The mass per inch of precipitation and annual precipitation are plotted for 1987 through 1997 for all three outfalls in Figure 11-4.

Table 11-1 Mass of Uranium Discharged from NPDES Storm Water Outfalls

\begin{tabular}{|c|c|c|c|c|c|c|c|c|c|c|c|}
\hline YEAR & 1987 & 1988 & 1989 & 1990 & 1991 & 1992 & 1993 & 1994 & 1995 & 1996 & 1997 \\
\hline (PPT) (inches) & 35.8 & 33.9 & 28.5 & 45.1 & 36.9 & 33.4 & 54.7 & 34.7 & 39.3 & 43.9 & 31.5 \\
\hline $\mathrm{NP}-0002(\mathrm{~kg})$ & 42 & 25 & 22 & 33 & 32 & 41 & 66 & 36 & 20.6 & 14.3 & 2.3 \\
\hline $\begin{array}{l}\text { Mass/lnch of } \\
\text { PPT (kg/in) }\end{array}$ & 1.17 & 0.74 & 0.77 & 0.73 & 0.87 & 1.23 & 1.21 & 1.03 & 0.52 & 0.33 & 0.07 \\
\hline $\mathrm{NP}-0003(\mathrm{~kg})$ & 362 & 176 & 35 & 17.7 & 73 & 75 & 163 & 49 & 12.6 & 19.1 & 19.2 \\
\hline $\begin{array}{l}\text { Mass/Inch of } \\
\text { PPT (kg/in) }\end{array}$ & 10.11 & 5.19 & 1.23 & 0.39 & 1.98 & 2.25 & 2.98 & 1.41 & 0.32 & 0.44 & 0.61 \\
\hline $\mathrm{NP}-0005(\mathrm{~kg})$ & 38 & 26 & 15 & 25 & 27 & 16 & 31 & 12 & 5.0 & 4.0 & 0.5 \\
\hline $\begin{array}{l}\text { Mass/lnch of } \\
\text { PPT (kg/in) }\end{array}$ & 1.06 & 0.77 & 0.53 & 0.55 & 0.73 & 0.48 & 0.57 & 0.34 & 0.13 & 0.09 & 0.02 \\
\hline Total Mass $\mathrm{Kg}(\mathrm{a})$ & 442 & 227 & 72 & 75.7 & 132 & 132 & 260 & 97 & 38.2 & 37.4 & 22.0 \\
\hline
\end{tabular}

PPT Precipitation

(a) Includes Outfalls NP-0002, NP-0003 and NP-0005. Other ofalls are negligible. 


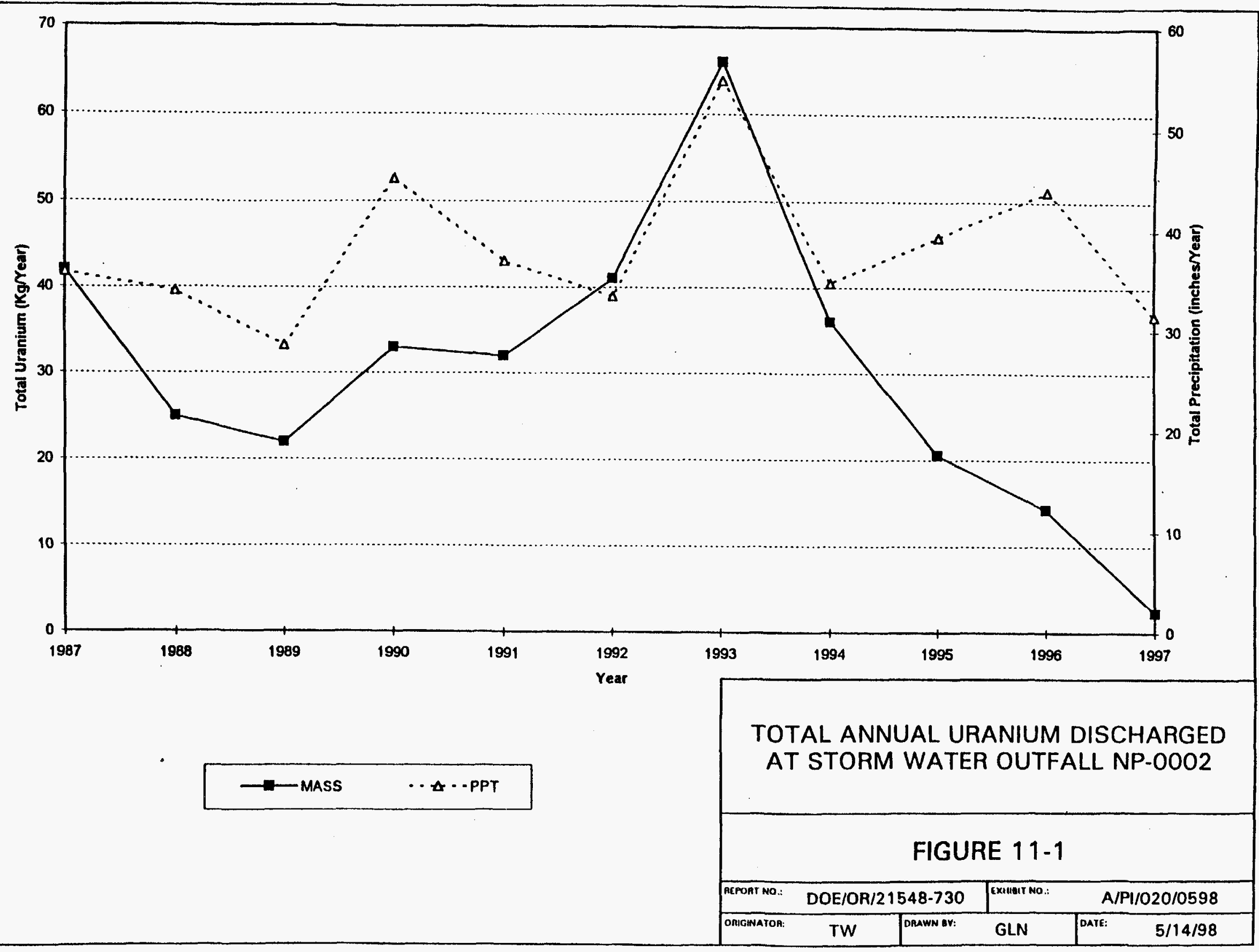




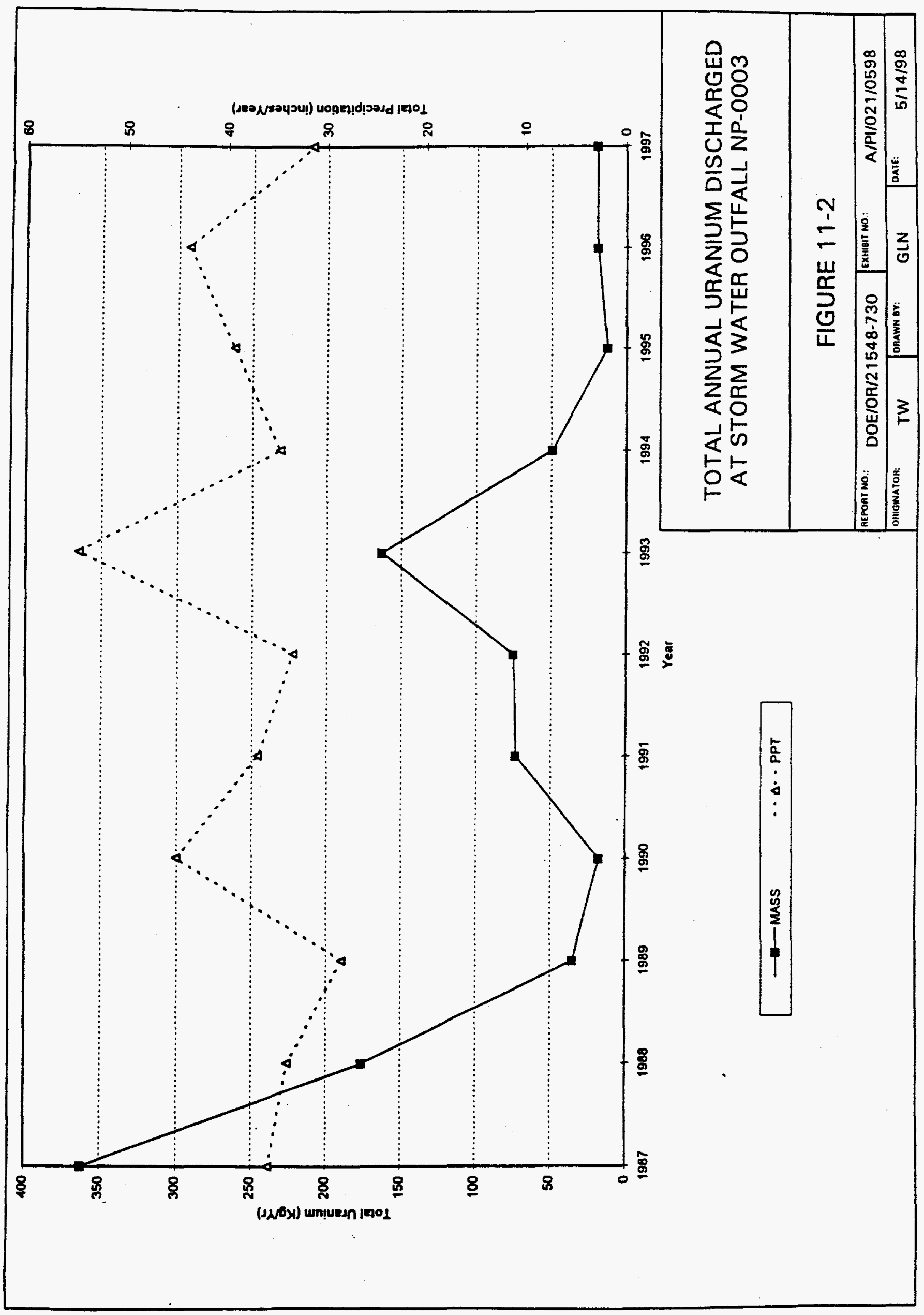




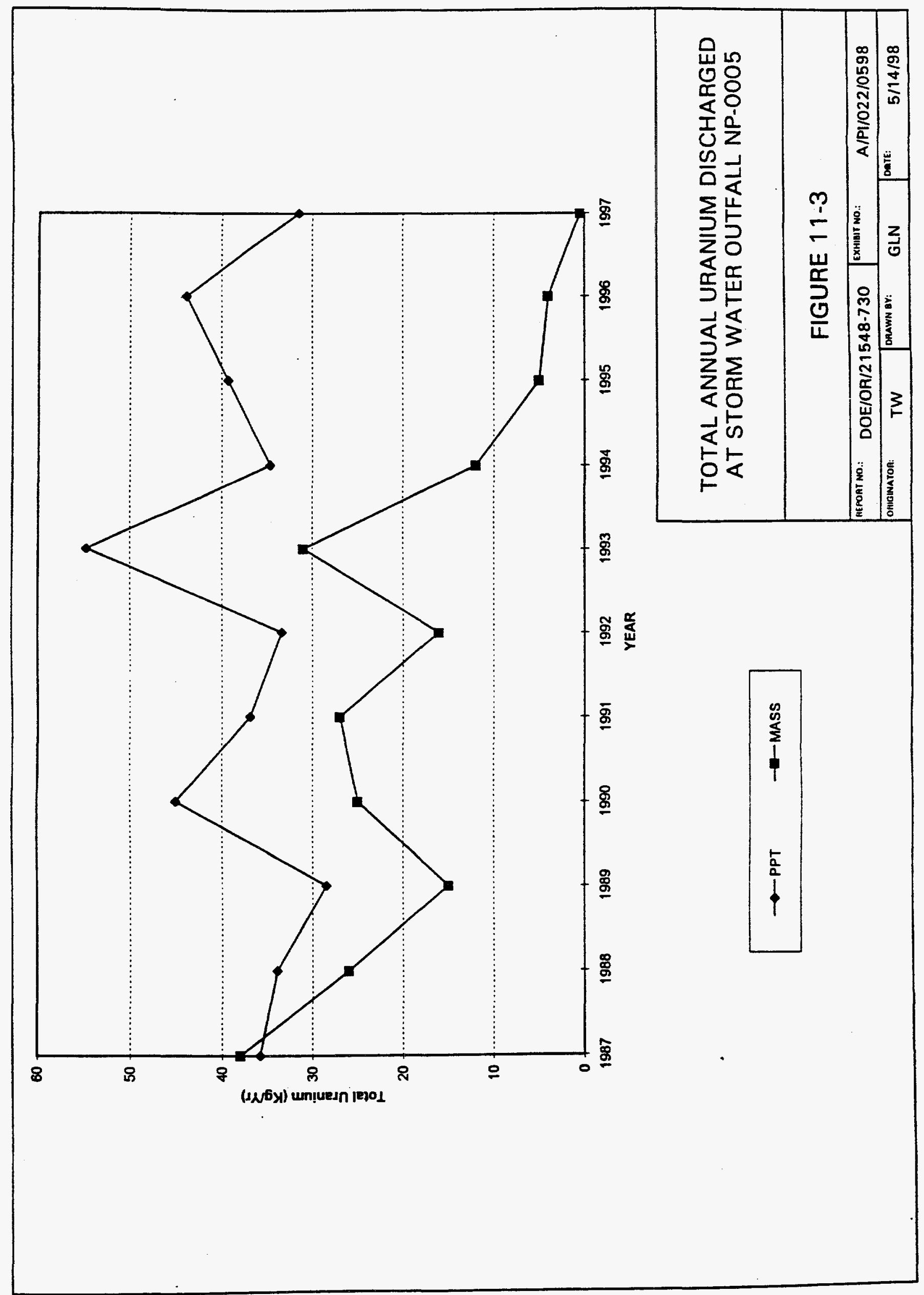




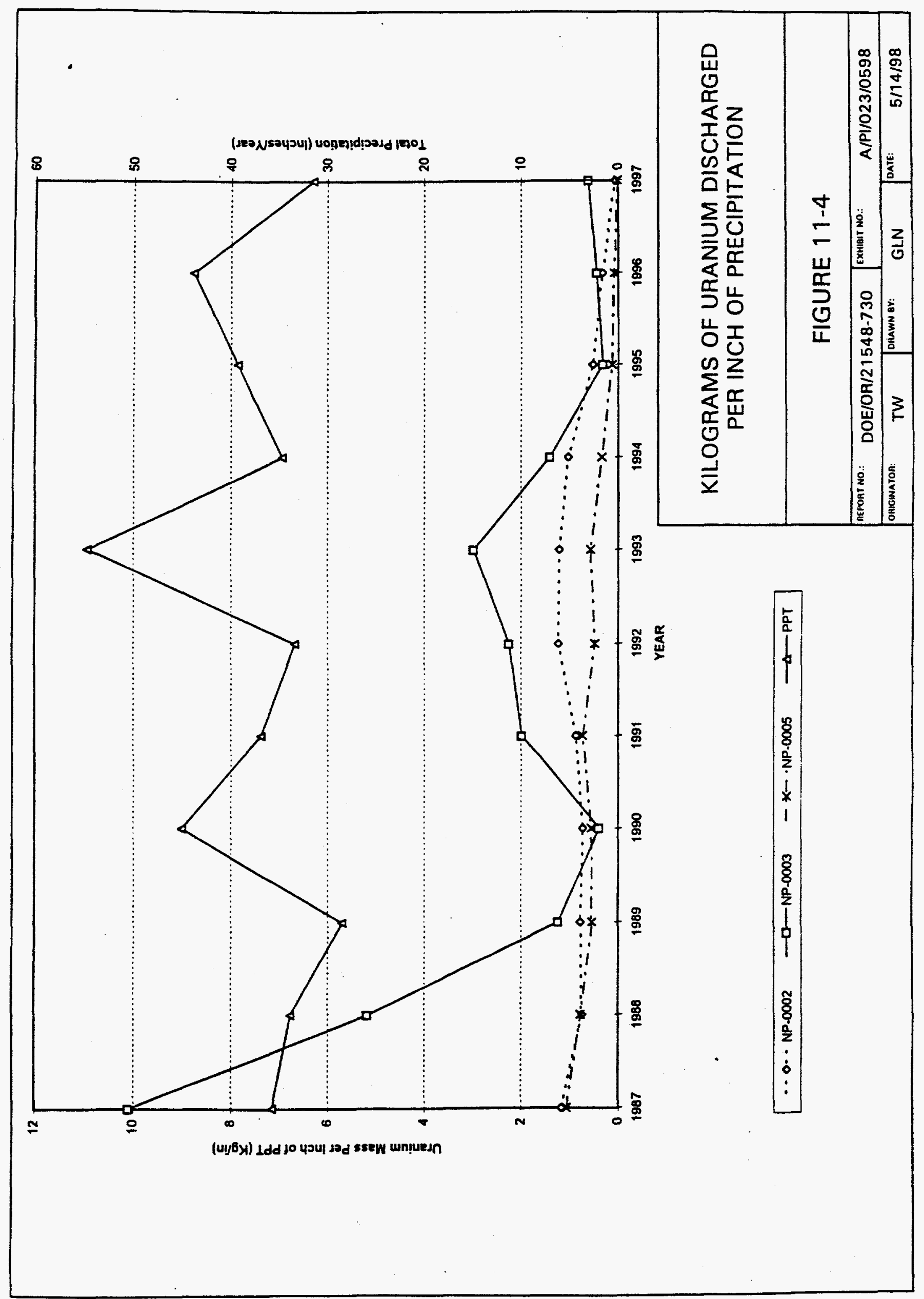




\section{Storm Water Outfall NP-0002}

Outfall NP-0002 is downstream of Frog Pond and receives runoff from the eastern section of the chemical plant. Figure 11-1 indicates that uranium migrating off site initially decreased or increased in relative proportion to annual precipitation before remediation started. Building dismantlement occurred in 1992, which appears to have increased the mass of uranium migrating off site, although precipitation was less than the previous year. With the completion of building dismantlement, the positive correlation of uranium versus precipitation resumed until 1995 when precipitation increased and uranium decreased. This trend continued into 1996.

Mass reduction in 1995 was presumed to be due to precipitation patterns, since the reductions were similar at all three outfalls, although activities in the three watersheds differed. The reduction in 1996 is believed to be due to action of the sedimentation basin in addition to the removal of contaminated soil and building foundations. The downward trend continued in 1997. Uranium discharged at Outfall NP-0002 is expected to remain low because contaminated soils and foundations were removed from most of the watershed during 1997.

\section{Storm Water Outfall NP-0003}

Figure 11-2 indicates that uranium migrating off site sharply decreased from 1987 to 1989 at Outfall NP-0003. The reduction for 1988 is assumed to be due to precipitation patterns since there was no other activity in the watershed. The reduction in 1989 was due to construction of the Ash Pond diversion channel, which began in November of 1988 and was completed in April of 1989 , along with lower precipitation in 1989. Prior to construction of the diversion channel, most of the water in the watershed flowed through Ash Pond, which is a highly contaminated area. Following construction of the diversion channel, the only water that flowed from Ash Pond was precipitation that fell directly on the pond area.

Construction of the diversion channel made the annual uranium mass at Outfall NP-0003 highly dependent on the flow from Ash Pond. During the summer, and other dry periods, there may be little or no flow from the pond. As a result, the diversion channel flow (from a much less contaminated area of the site) made up the bulk of the flow. This caused overall lower uranium levels at the outfall during periods of normal precipitation.

During winter, when the Ash Pond soils have become saturated and precipitation amounts generally have been higher, flow from Ash Pond increased and concentrations at the outfall trended higher. The mass in 1990 was again reduced over the previous year, although precipitation was much higher. This may have been a result of precipitation patterns and/or the times the samples were taken (i.e., no flow from Ash Pond). During 1991 and 1992, precipitation was less than in 1990, but uranium mass was higher. Again, this presumably was due to precipitation patterns and the time of sample collection. 
Uranium mass increased greatly in 1993 because precipitation increased dramatically and Ash Pond discharged throughout the year. Mass decreased in 1994 with the decrease in precipitation and a soil cover placed over the South Dump area of Ash Pond during the middle of the year. Mass was again reduced in 1995 with an increase in precipitation. This was likely the result of precipitation patterns (because reductions were similar at all three outfalls) and the construction during 1995 of a sedimentation basin immediately upstream of Outfall NP-0003. Mass increased slightly in 1996 due to increased precipitation and the storage of contaminated soil and debris in Ash Pond. With the storage of soil and debris in Ash Pond, the water is managed and is not discharged to the sedimentation basin unless it is less than the $600 \mathrm{pCi} / 1(22.2 \mathrm{~Bq} / \mathrm{l})$ Derived Concentration Guideline (DCG). With the storage of contaminated materials in Ash Pond, the mass of uranium at Outfall NP-0003 is expected to be highly dependent on precipitation and water discharged from Ash Pond. The mass of uranium discharged during 1997 was slightly higher than that discharged during 1997 even though precipitation was much less. This was likely the result of the storage of contaminated materials in Ash Pond.

\section{$\underline{\text { Storm Water Outfall NP-0005 }}$}

Figure 11-3 indicates that the mass of uranium migrating off site at Outfall NP-0005 has been generally proportional with annual precipitation. The construction of the site water treatment plant, beginning in 1992 with much earth disturbance for construction of the effluent and equalization basins, appears to have had little effect on the outfall. A siltation basin was constructed to settle sediments from the water flowing off the treatment plant area. The storm water from the site water treatment plant sedimentation basin is generally less than $10 \mathrm{pCi} / 1$ $(0.37 \mathrm{~Bq} / \mathrm{l})$ for uranium. The other major source for the Outfall (until it was remediated in 1996) was a watershed that drained the highly contaminated Building 301 area. This area was partially capped during 1994 to decrease the concentration of uranium in storm water leaving the area.

The concentration of uranium in storm water from individual sampling events was highly dependent on precipitation rates, periods between precipitation, and the ratio of flow from the sedimentation basin and the Building 301 area. The mass of uranium migrating off site was reduced in 1995 and again in 1996. The reduction in 1995 is likely the result of precipitation patterns, because all three outfalls had similar reductions. The watershed for NP-0005 was remediated during 1996. This resulted in another reduction in uranium mass leaving the site in 1996. The mass of uranium migrating off site at Outfall NP-0005 for 1997 was much reduced over 1996 because 1997 was the first complete year where the watershed was almost completely remediated. Uranium mass is expected to remain close to background levels at Outfall NP-0005. 


\section{Mass of Uranium Per Inch of Precipitation}

Figure 11-4 and Table 11-1 indicate that mass of uranium migrating from the site per inch of precipitation has relatively flat trend lines for the three major outfalls. This indicates that, all other factors remaining constant, the mass of uranium migrating off site is dependent upon annual precipitation and the contamination level in the watershed. Outfalls NP-0002 and NP-0005 show similar levels, with NP-0003 showing relatively higher levels. This is to be expected because the Outfall NP-0003 watershed contains Ash Pond, which is a highly contaminated area. Variations may be due to precipitation patterns, soil disturbance, or remediation and in the case of Outfall NP-0003, the storage of contaminated materials in Ash Pond. Outfalls NP-0002 and NP-0005 have trended down as a result of remediation efforts in the watershed. Outfall NP-0003 increased slightly for 1997 because of the storage of contaminated materials in Ash Pond. The mass per inch of precipitation is expected to trend downward with the completion of remediation in the watersheds of the major outfalls.

\section{Annual Migration of Uranium Mass from the WSSRAP}

The mass of uranium that migrated off site in 1987 , before any remedial actions were taken, was $442 \mathrm{~kg}$ (972 lb). During $1997,22.2 \mathrm{~kg}(48.8 \mathrm{lb})$ of uranium migrated off site, a $95 \%$ reduction from the 1987 mass. Table 11-1 shows the mass of uranium that migrated off site during the intervening years. Mass has fluctuated from year to year with precipitation levels, remedial actions, land disturbance, and finally, foundation and contaminated soil removal. The masses during 1995 and 1996 were at similar levels of $38.2 \mathrm{~kg}(84 \mathrm{lb})$ and $37.4 \mathrm{~kg}(82 \mathrm{lb})$. Because contaminated soil removal was completed for major sections of the site during 1996 , levels for 1997 were reduced even further. Outfall NP-0003 mass has not followed this trend because the contaminated soil removed from other areas of the site is stored in Ash Pond, which is in the NP-0003 watershed. Ash Pond is managed to prevent water greater than $600 \mathrm{pCi} / \mathrm{l}$ (22.2 Bq/1) from discharging from Ash Pond; therefore, effluent at Outfall NP-0003 will not exceed $600 \mathrm{pCi} / 1(22.2 \mathrm{~Bq} / \mathrm{l})$. Additional efforts will be made, if required, to keep uranium migrating from Outfall NP-0003 as low as reasonably achievable.

\subsection{Baseline Monitoring at NPDES Outfalls NP-0002, NP-0003, and NP-0005}

The NPDES storm water Outfalls NP-0002, NP-0003, and NP-0005 were sampled once a month for Ra-226, Ra-228, Th-228, Th-230, Th-232, 2,4-DNT, 2,4,6-TNT, hazardous substance list (HSL) metals, polychlorinated biphenyls (PCBs), and polycyclic (or polynuclear) aromatic hydrocarbons (PAHs) starting in September 1994 and continuing through February 1995. These parameters were analyzed to establish baseline concentrations before removal of contaminated building foundations. The averages for the 6 months of baseline monitoring are shown in Tables 11-2 and 11-3. Radium and thorium were detected either at very low activities or were not detected. The chemical parameters were also present at low levels. The baseline concentrations 
were calculated by using the averages in Tables 11-2 and 11-3 and adding two standard deviations. The baseline concentrations have been and will be used by data reviewers for comparison to sample data in conjunction with Procedure ES\&H 1.1.7, Environmental Data Review and Above Normal Reporting.

Table 11-2 Average Radiological Concentrations ( $\mathrm{pCi} / \mathrm{l}$ ) for Storm Water Outfalls NP-0002, NP-0003, NP-0005 Baseline Monitoring for September 1994 to February 1995

\begin{tabular}{|l|l|l|l|l|l|}
\hline LOCATION & Ra-226 & Ra-228 & Th-228 & Th-230 & Th-232 \\
\hline NP-0002 & 0.45 & 0.88 & 0.53 & 0.34 & 0.35 \\
\hline NP-0003 & 0.40 & 0.63 & 0.37 & 0.39 & 0.35 \\
\hline NP-0005 & 0.48 & 0.94 & 0.31 & 0.29 & 0.26 \\
\hline
\end{tabular}

Note: $\quad 1 \mathrm{pCi} / \mathrm{l}=0.037 \mathrm{Bg} / \mathrm{l}$ 
Table 11-3 Average Chemical Concentrations $(\mu \mathrm{g} / \mathrm{l})$ for Storm Water Outfalis NP-0002, NP-0003, and NP-0005 Baseline Monitoring for September 1994 to February 1995

\begin{tabular}{|c|c|c|c|}
\hline LOCATION PARAMETER & NP-0002 & NP-0003 & NP-0005 \\
\hline $2,4-\mathrm{DNT}$ & $<0.20$ (a) & $<0.20(a)$ & $<0.20$ (a) \\
\hline $2,4,6-T N T$ & $<0.26(a)$ & $<0.26(b)$ & $<0.26(\mathrm{a})$ \\
\hline $\mathrm{Al}$ & $1.840^{*}$ & $1.302^{*}$ & $3.892^{*}$ \\
\hline Sb & $<11.67(\mathrm{a})$ & $<11.67(\mathrm{a})$ & $<11.67(\mathrm{a})$ \\
\hline As & 3.07 & 3.75 & 2.37 \\
\hline $\mathrm{Ba}$ & 80.97 & 82.13 & 90.85 \\
\hline $\mathrm{Be}$ & 0.48 & 0.37 & 0.37 \\
\hline $\mathrm{Cd}$ & 1.42 & 1.42 & 1.42 \\
\hline $\mathrm{Ca}$ & $61.100^{*}$ & $78.433^{\star}$ & $67.600^{*}$ \\
\hline $\mathrm{Cr}_{\mathrm{r}}$ & 5.16 & 5.01 & 6.77 \\
\hline Co & 3.40 & 3.40 & 3.93 \\
\hline $\mathrm{Cu}$ & 7.20 & 5.92 & 7.03 \\
\hline $\mathrm{Fe}$ & $1.603^{*}$ & $1.152^{*}$ & $2.888^{\star}$ \\
\hline $\mathrm{Pb}$ & 7.65 & 3.33 & 4.33 \\
\hline $\mathrm{Li}$ & 14.23 & 4.95 & 4.33 \\
\hline$\overline{\mathrm{Mg}}$ & $12.215^{\star}$ & $14.467^{*}$ & $12.352^{*}$ \\
\hline $\mathrm{Mn}$ & 185.85 & 41.28 & 73.67 \\
\hline $\mathrm{Hg}$ & 0.24 & 0.08 & 0.08 \\
\hline Mo & 6.13 & 7.15 & 5.70 \\
\hline $\mathrm{Ni}$ & 10.23 & 10.83 & 12.40 \\
\hline $\mathrm{K}$ & $5.21^{\star}$ & $5.03^{\star}$ & $3.71^{*}$ \\
\hline $\mathrm{Se}$ & 2.38 & 3.23 & 1.94 \\
\hline $\mathrm{Ag}$ & 1.93 & 1.93 & 1.67 \\
\hline $\mathrm{TI}$ & 2.81 & 1.98 & 1.85 \\
\hline $\mathbf{V}$ & 4.47 & 4.68 & 8.45 \\
\hline $\mathrm{Zn}$ & 55.40 & 31.28 & 48.75 \\
\hline PCBS & (c) & $1.0(\mathrm{~d})$ & $1.0(\mathrm{~d})$ \\
\hline PAHs & $<20(e)$ & $<20(e)$ & $<20(e)$ \\
\hline
\end{tabular}

* $\mathrm{mg} / \mathrm{l}$.

(a) All nondetect.

(b) All nondetect with one detect of $0.0491 \mu \mathrm{g} / \mathrm{l}$.

(c) N.D. at <1.0 except 1 detect at $0.18 \mu \mathrm{g} / \mathrm{l}$ and one Aroclor-1221 N.D. at D.L. of $2.0 \mu \mathrm{g} / \mathrm{l}$

(d) Except one Aroclor-1221 N.D. at D.L. of $2.0 \mu \mathrm{g} / \mathrm{l}$.

(e) All N.D. with the maximum D.L. being $20 \mu \mathrm{g} /$. 


\section{REFERENCES}

1. Department of Energy, Assistant Secretary for Environment, Safety and Health Environmental Regulatory Guide for Radiological Effluent Monitoring and Environmental Surveillance, DOE/EH-0173T. Washington, DC. January 1991.

2. MK-Ferguson Company and Jacobs Engineering Group. Remedial Investigations for Quarry Bulk Wastes, Rev 1. DOE/OR/21548-066. Prepared for the U.S. Department of Energy, Oak Ridge Operations Office, Weldon Spring Site Remedial Action Project. December 1989.

3. MK-Ferguson Company and Jacobs Engineering Group. Remedial Investigation for the Chemical Plant Area of the Weldon Spring Site, Rev. 0, 2 Vols. DOE/OR/21548-074. Prepared for the U.S. Department of Energy, Oak Ridge Field Office, Weldon Spring Site Remedial Action Project. St. Charles, MO. November 1992.

4. Kleeschulte, M.J., L.F. Emmett, and J.H. Barks. Hydrologic Data for the Weldon Spring Radioactive Waste-Disposal Sites, St. Charles County, Missouri - 1984-1986, U.S. Geological Survey Open-File Report 86-488. Rolla, MO. 1986.

5. Argonne National Laboratory. Feasibility Study for Management of the Bulk Wastes at the Weldon Spring Quarry, Weldon Spring, Missouri. DOE/OR/21548-104. Prepared for the U.S. Department of Energy, Oak Ridge Operations Office, Weldon Spring Site Remedial Action Project. St. Charles, MO. February 1990.

6. MK-Ferguson Company and Jacobs Engineering Group. Agricultural Sampling Plan, Rev. 1. DOE/OR/21548-229. Prepared for the U.S. Department of Energy, Oak Ridge Field Office. St. Charles, MO. December 1992.

7. Ruffner, James A. and Frank E. Bair. Weather of U.S. Cities, City Reports, Alabama Missouri, Volume 1. Third Edition. Gale Research Company, Detroit, MI.

8. MK-Ferguson Company and Jacobs Engineering Group. Environmental Protection Program Implementation Plan, Rev. 5. DOE/OR/21548-095. Prepared for the U.S. Department of Energy, Oak Ridge Field Office. Weldon Spring, MO. December 1993.

9. MK-Ferguson Company and Jacobs Engineering Group. Weldon Spring Site Environmental Report for Calendar Year 1993, Rev. 0. DOE/OR/21548-436. Prepared for the U.S. Department of Energy, Oak Ridge Operations Office. St. Charles, MO. May 1994. 
10. Argonne National Laboratory. Work Plan for the Remedial Investigation/Feasibility StudyEnvironmental Assessment for the Quarry Residuals Operable Unit at the Weldon Spring Site. DOE/OR/21548-243. Prepared for the U. S. Department of Energy, Weldon Spring Site Remedial Action Project by the Environmental Assessment Division. St. Charles, MO. January 1994.

11. MK-Ferguson Company and Jacobs Engineering Group. Quarry Residuals Sampling Plan, Rev. 1. DOE/OR/21548-382. Prepared for the U.S. Department of Energy, Oak Ridge Operations Office. St. Charles, MO. January 1994.

12. MK-Ferguson Company and Jacobs Engineering Group. Leachate Production Action Response Plan, Rev. 2. DOE/OR/21548-477. Prepared for the U.S. Department of Energy, Oak Ridge Operations Office. St. Charles, MO. August 1996.

13. MK-Ferguson Company and Jacobs Engineering Group. Groundwater Protection Program Management Plan, Rev. 3. DOE/OR/21548-123. Prepared for the U.S. Department of Energy, Oak Ridge Operations Office. St. Charles, MO. July 1992.

14. MK-Ferguson Company and Jacobs Engineering Group. Surface Water Management Plan, Rev. 2. DOE/OR/21548-221. Prepared for the U.S. Department of Energy, Oak Ridge Operations Office. St. Charles, MO. July 1996.

15. MK-Ferguson Company and Jacobs Engineering Group. Weldon Spring Site Environmental Report for Calendar Year 1995. Rev. 0. DOE/OR/21548-592. Prepared for the U. S. Department of Energy, Oak Ridge Operations Office. St. Charles, MO. June 1996.

16. MK-Ferguson Company and Jacobs Engineering Group. Waste Minimization/Pollution Prevention Awareness Plan, Rev. 5. DOE/OR/21548-124. Prepared for the U.S. Department of Energy, Oak Ridge Operations Office. St. Charles, MO. January 1998.

17. MK-Ferguson Company and Jacobs Engineering Group. Self-Assessment Program Implementation Plan, Rev. 1. DOE/OR/21548-385. Prepared for the U.S. Department of Energy, Oak Ridge Field Office. St. Charles, MO. February 1995.

18. Argonne National Laboratory. Mitigation Action Plan for the Remedial Action at the Chemical Plant Area of the Weldon Spring Site, Rev. 0. Prepared for U.S. Department of Energy, Oak Ridge Operations Office. St. Charles, Missouri. November 1993.

19. MK-Ferguson Company and Jacobs Engineering Group. Wetlands Project Plan for COE Permit Application, Rev. A. DOE/OR/21548-437. Prepared for the U.S. Department of Energy, Oak Ridge Operations Office. St. Charles, Missouri. January 1994. 
20. MK-Ferguson Company and Jacobs Engineering Group. Waste Management Plan, Rev. 8. DOE/OR/21548-166. Prepared for the U.S. Department of Energy, Oak Ridge Operations Office. St. Charles, MO. September 1997.

21. MK-Ferguson Company and Jacobs Engineering Group. Plan for Monitoring Radionuclide Emissions Other Than Radon at Weldon Spring Site Critical Receptors, Rev. 4. DOE/OR/21548-127. Prepared for the U.S. Department of Energy, Oak Ridge Operations Office. St. Charles, MO. October 1997.

22. MK-Ferguson Company and Jacobs Engineering Group. Project Management Contractor Quality Assurance Program, Rev. 2. DOE/OR/21548-333. Prepared for the U.S. Department of Energy, Oak Ridge Operations Office. St. Charles, MO. December 1995.

23. MK-Ferguson Company and Jacobs Engineering Group. Project Management Contractor Quality Assurance Program Implementation Plan. Rev. 0. DOE/OR/21548-506. Prepared for the U. S. Department of Energy, Oak Ridge Operations Office. St. Charles, MO. November 1994.

24. U.S. Department of Energy. Record of Decision for Remedial Action at the Chemical Plant Area of the Weldon Spring Site. DOE/OR/21548-376. Oak Ridge Field Office. St. Charles, MO. September 1993.

25. Snyder, W.S., M. J. Cook, L. R. Karhauser, E. S. Nasset, G. P. Howells, and I. H. Tipton. Report of the Task Group on Reference Man, ICRP Report No. 23. Published for International Commission on Radiological Protection, by Pergamon Press, New York. October 1974.

26. The International Commission on Radiological Protection. Recommendations of the International Commission on Radiological Protection, ICRP Publication 26. Published by Pergamon Press, New York. January 17, 1977.

27. International Commission on Radiological Protection. Limits for Intakes of Radionuclides by Workers, Part 1, ICRP Publication 30. Published by Pergamon Press. New York, New York. July 1978.

28. Eckerman, K.F., A.B. Wolbarst, and A.C.B. Richardson. Limiting Values of Radionuclide Intake and Air Concentration and Dose Conversion Factors for Inhalation, Submersion, and Ingestion, Federal Guidance Report No. 11. Prepared for U.S. Environmental Protection Agency, by Oak Ridge National Laboratory. Oak Ridge, TN. September 1988. 
29. Environmental Protection Agency. Statement of Work for Inorganics Analysis Multi-Media Multi-Concentration, SOW No. 788. USEPA Contract Laboratory Program. February 1989 and June 1989.

30. Missouri Department of Conservation. Recreational Use of Weldon Spring Wildlife Area 1989-1990, Public Profile 6-91. June 1991.

31. International Commission on Radiological Protection. Limits for Inhalation of Radon Daughters by Workers, ICRP Publication No. 32. Published by Pergamon Press. New York, New York. March 1981.

32. Environmental Protection Agency. Superfund Exposure Assessment Manual, OSWER Directive 9285.5-1. 1988.

33. United Nations Scientific Committee on the Effects of Atomic Radiation. 37th Session, Suppl. No. 45 (A/37/45). United Nations, New York. 1982.

34. MK Environmental Services. WSSRAP Chemical Plant Surface Water and Erosion Control Report, Rev. 0. DOE/OR/21548-253. Prepared for MK-Ferguson Company. St. Charles, MO. October 1991.

35. Environmental Protection Agency, Office of Water Regulations and Standards. Quality Criteria for Water 1986, EPA 440/5-86-001. Washington, D.C. May 1, 1986.

36. Missouri Department of Natural Resources. Rules of Department of Natural Resources Division 20 - Clean Water Commission, Chapter 7-Water Quality. Code of State Regulations. January 1992.

37. Kleeschulte, Michael J. and Jeffrey L. Imes. Geohydrology, Extent of Contamination, and Simulation of Ground-Water Flow at the Weldon Spring Chemical Plant Site and Vicinity Property, St. Charles County, Missouri - 1987-1990, Water-Resources Investigations Report 93-XXXX. Prepared in cooperation with the U.S. Department of Energy, Rolla, Missouri. 1993.

38. Schumacher, John G. Geochemistry and Migration of Contaminants at the Weldon Spring Chemical Plant Site, St. Charles County, Missouri-1989-91, U.S. Geological Survey, OpenFile Report 93-433. Prepared in cooperation with the U.S. Department of Energy. Rolla, MO. 1993. 
39. Fink, S.A. Uptake of Nitroaromatic Compounds by Weldon Spring Soils. A Thesis Presented to the Faculty of the Graduate School of the University of Missouri-Rolla in partial fulfillment of the requirements for the Degree of Master of Science in Civil Engineering. 1963.

40. MacDonell, M.M., J.M. Peterson, and I.E. Joya. Engineering Evaluation/Cost Analysis for the Proposed Management of Contaminated Water in the Weldon Spring Quarry. DOE/OR/21548-039. Prepared for the U.S. Department of Energy, Oak Ridge Operations Office, Weldon Spring Site Remedial Action Project. January 1989.

41. Haroun, L.A., J. M. Peterson, M.M. MacDonell, and I. Hlohowskyj. Baseline Risk Evaluation for Exposure to Bulk Wastes at the Weldon Spring Quarry, Weldon Spring, Missouri. DOE/OR/21548-065. Prepared for the U.S. Department of Energy, Oak Ridge Operations Office. St. Charles, MO. January 1990.

42. MK-Ferguson Company and Jacobs Engineering Group. Environmental Monitoring Plan, Rev. 5. DOE/OR/21548-424. Prepared for the U.S. Department of Energy, Oak Ridge Operations Office. St. Charles, MO. January 1998.

43. Environmental Protection Agency, Office of Waste Programs Enforcement, Office of Solid Waste and Emergency Response. RCRA Ground-Water Monitoring Technical Enforcement Guidance Document, OSWER-9950.1. September 1986.

44. MK-Ferguson Company and Jacobs Engineering Group. Environmental Quality Assurance Project Plan, Rev. 2. DOE/OR/21548-352. Prepared for the U.S. Department of Energy, Oak Ridge Operations Office. St. Charles, MO. May 1996.

45. MK-Ferguson Company and Jacobs Engineering Group. Environmental Safety and Health Plan, Rev. 2. DOE/OR/21548-172. Prepared for the U.S. Department of Energy, Oak Ridge Operations Office, Weldon Spring Site Remedial Action Project. St. Charles, MO. February 1992.

46. Aller, L., T. W. Bennett, G. Hackett, R.J. Petty, J.H. Lehr, H. Sedoris, D.M. Nielsen, and J.E. Denne. Handbook of Suggested Practices for the Design and Installation of GroundWater Monitoring Wells, EPA 600/4-89/034. Prepared in cooperation with the National Water Well Association, by Environmental Monitoring Systems Laboratory. Las Vegas, Nevada. 1989.

47. American Public Health Association, American Water Works Association, Water Environment Federation. Standard Methods for the Examination of Water and Wastewater, 18th Ed. Washington, D.C. 1992. 
48. MK-Ferguson Company and Jacobs Engineering Group. Dam Safety Operations Emergency Preparedness Plan, Rev. 2. DOE/OR/21548-306. Prepared for the U.S. Department of Energy, Oak Ridge Operations Office. St. Charles, MO. August 1996.

49. Pearson, Mark D. and Robert R. Spangler. "Calibration of Alpha-Track Monitors for Measurement of Thoron." Health Physics, Vol. 40, No. 5. May 1991.

50. MK-Ferguson Company and Jacobs Engineering Group. Radiological and Chemical Uptake in Game Species at the Weldon Spring Site, Rev. 1. DOE/OR/21548-426. Prepared for the U.S. Department of Energy, Oak Ridge Operations Office. St. Charles, MO. July 1995.

51. MK-Ferguson Company and Jacobs Engineering Group. Environmental Data Administration Plan, Rev. 3. DOE/OR/21548-119. Prepared for the U.S. Department of Energy, Oak Ridge Operations Office. St. Charles, MO. August 1993.

52. Environmental Protection Agency. RCRA Ground-Water Monitoring: Draft Technical Guidance, EPA/530-R-93-001. Prepared by the Office of Solid Waste, Washington, D.C. November 1992.

53. MK-Ferguson Company and Jacobs Engineering Group. Plan to Address Radon Emission Requirements at the Weldon Spring Quarry. Rev. 0. DOE/OR/21548-501. Prepared for the U. S. Department of Energy, Oak Ridge Operations Office. St. Charles, MO. November 1994.

54. MK-Ferguson Company and Jacobs Engineering Group. Annual Site Environmental Report for Calendar Year 1990, Rev. 1. DOE/OR/21548-193. Prepared for the U.S. Department of Energy, Oak Ridge Operations Office. St. Charles, MO. September 1991.

55. Department of Transportation. Design of Roadside Drainage Channels. Hydraulic Design Series No. 4. Prepared by the Federal Highway Administration. Washington, DC. Reprinted 1973.

56. Shleien, Bernard, ed. The Health Physics and Radiological Health Handbook, Revised Edition. Scinta, Inc., Silver Spring, Maryland. 1992.

57. Argonne National Laboratory. Record of Decision for the Management of the Bulk Wastes at the Weldon Spring Quarry, Rev. 0. DOE/OR/21548-317. St. Charles, MO. September 1990. 
58. Brugam, R.B., E. Danielson, C.T. Hubbard, M. Malick. Aquatic Biological Screening Investigation at the Weldon Spring Site. Prepared by Department of Biological Sciences, Southern Illinois University. Edwardsville, IL. No date.

59. Environmental Science \& Engineering, Inc. Weldon Spring Remedial Action Project 1992 Aquatic Biological Monitoring - WP305, Final Report, ESE No. 592-1043-0400. Prepared for M.K. Ferguson Company (sic), St. Louis, Missouri. April 1993.

60. Environmental Science and Engineering, Inc. 1994 Aquatic Surveillance Monitoring Program WP-402, ESE No. 593-1109-0600. Prepared for MK-Ferguson Company. St. Charles, MO. June 21, 1995.

61. MK-Ferguson Company and Jacobs Engineering Group. Sample Management Guide. Rev. 0. DOE/OR/21548-499. Prepared for the U. S. Department of Energy, Oak Ridge Operations Office. St. Charles, MO. March 1995.

62. Environmental Protection Agency. Contract Laboratory Program Statement of Work for Inorganics Analysis, Multi-Media Multi-Concentration. Document Number ILMO1.0.

63. Environmental Protection Agency. Contract Laboratory Program Statement of Work for Organic Analysis, Multi-Media, Multi-Concentration. Document Number OLMO1.0.

64. Rucker, Thomas L. and C. Martin Johnson, Jr. Laboratory Data Validation Guidelines for Evaluating Radionuclide Analyses. Prepared for MK-Ferguson Company and Jacobs Engineering Group by Science Applications International Corporation (SAIC). SAIC Document No. 143-ARCS-92.01. Oak Ridge. December 1992.

65. Environmental Protection Agency. EPA Requirements for Quality Assurance Project Plans for Environmental Data Operations. EPA QA/R-5. August 1994.

66. MK-Ferguson Company and Jacobs Engineering Group. Weldon Spring Site Environmental Report for Calendar Year 1994. Rev. 0. DOE/OR/21548-512. Prepared for the U. S. Department of Energy, Oak Ridge Operations Office. St. Charles, MO. May 1995.

67. Argonne National Laboratory, Environmental Assessment Division. Work Plan for the Remedial Investigation/Feasibility Study for the Groundwater Operable Units at the Chemical Plant Area and the Ordnance Works Area, Weldon Spring, Missouri. DOE/OR/21548-567. Prepared for the U.S. Department of Energy, Oak Ridge Operations Office. St. Charles, Missouri. August 1995. 
68. MK-Ferguson Company and Jacobs Engineering Group. Sampling Plan for the Remedial Investigation/Feasibility Study for the Groundwater Operable Units at the Chemical Plant Area and at the Ordnance Works Area, Weldon Spring, Missouri (Appendix to the Work Plan), Rev. 1. DOE/OR/21548-445. Prepared for the U.S. Department of Energy, Oak Ridge Operations Office. St. Charles, MO. July 1995.

69. Department of Energy. Feasibility Study for Remedial Action at the Chemical Plant Area of the Weldon Spring Site, 2 Vols. DOE/OR/21548-148. Oak Ridge Field Office, Weldon Spring Site Remedial Action Project. St. Charles, MO. November 1992.

70. Argonne National Laboratory. Engineering Evaluation/Cost Analysis for the Proposed Removal Action at the Southeast Drainage Near the Weldon Spring Site, Weldon Spring, Missouri. DOE/OR/21548-584. Prepared for the U. S. Department of Energy, Weldon Spring Site Remedial Action Project. Weldon Spring, MO. October 1995.

71. Committee on the Biological Effects of Ionizing Radiations Board on Radiation Effects Research Commission on Life Sciences National Research Council. Health Effects of Exposure to Low Levels of Ionizing Radiation, Beir V. National Academy Press. Washington, D.C. 1990

72. MK-Ferguson Company and Jacobs Engineering Group. 1996 Anmual Update to the Site Treatment Plan for the Weldon Spring Site Volume I - Compliance Plan; Volume II Background Volume. Rev. 0. DOE/OR/21548-645. Prepared for the U. S. Department of Energy, Oak Ridge Operations Office. St. Charles, MO. October 1996.

73. Cothern, C. Richard, and James E. Smith, Jr., editors. Environmental Radon. U.S. Environmental Protection Agency. Volume 35. Plenum Press. New York. 1987.

74. MK-Ferguson Company and Jacobs Engineering Group. Waste Assessment Radiological Characterization of the Weldon Spring Site Raffinate Pits, Rev. 0. DOE/OR/21548-062. Prepared for the U.S. Department of Energy, Oak Ridge Operations Office. St. Charles, Missouri. August 1989.

75. MK-Ferguson Company and Jacobs Engineering Group. Modeled Radon Emissions from Disposal Cell Operations, Rev. 1. DOE/OR/21548-612. Prepared for the U.S. Department of Energy, Oak Ridge Operations Office. St. Charles, Missouri. July 1997.

76. MK-Ferguson Company and Jacobs Engineering Group. Temporary Storage Area Radon Flux Monitoring Plan. Rev. 1. DOE/OR/21548-557. Prepared for the U.S. Department of Energy, Oak Ridge Operations Office. St. Charles, Missouri. January 1997. 
77. Professional Analysis, Inc. and Maxim Technologies, Inc. 1997 Wetlands Monitoring Report for the Weldon Spring Site Remedial Action Project. Prepared for the U.S. Department of Energy, Weldon Spring Site Remedial Action Project. February 1998.

78. MK-Ferguson Company and Jacobs Engineering Group. Weldon Spring Site Environmental Report For Calendar Year 1996. Rev. 0. DOE/OR/21548-676. Prepared for the U. S. Department of Energy, Oak Ridge Operations Office. St. Charles, MO. July 1997.

79. MK-Ferguson Company and Jacobs Engineering Group. Buildings Radiological Characterization Report, Rev. 0. DOE/OR/21548-120. Prepared for the U. S. Department of Energy, Oak Ridge Operations Office, Weldon Spring Site Remedial Action Project. St. Charles, MO. April 1990.

80. MK-Ferguson Company and Jacobs Engineering Group. Quarry Bulk Waste Excavation Remedial Action Report. Rev. 3. DOE/OR/21548-642. Prepared for the U. S. Department of Energy, Oak Ridge Operations Office. St. Charles, MO. March 1997.

81. MK-Ferguson Company and Jacobs Engineering Group. Remedial Investigation for the Quarry Residuals Operable Unit of the Weldon Spring Site, Weldon Spring Missouri.

Rev. 2. DOE/OR/21548-587. Prepared for the U. S. Department of Energy, Oak Ridge Operations Office. St. Charles, MO. February 1998.

82. Argonne National Laboratory. Baseline Risk Assessment for the Quarry Residuals Operable Unit of the Weldon Spring Site, Weldon Spring, Missouri. DOE/OR/21548-594. Prepared by the Environmental Assessment Division for the U.S. Department of Energy, Weldon Spring Site Remedial Action Project, Weldon Spring, Missouri. July 1997.

83. Argonne National Laboratory. Proposed Plan for Remedial Action at the Quarry Residuals Operable Unit of the Weldon Spring Site. Prepared for the U.S. Department of Energy, Weldon Spring Site Remedial Action Project, Weldon Spring Missouri. March 1998.

84. Argonne National Laboratory. Remedial Investigation for the Groundwater Operable Units at the Chemical Plant Area and the Ordnance Works Area, Weldon Spring, Missouri. DOE/OR/21548-571. Prepared for U.S. Department of Energy, Weldon Spring Site Remedial Action Project, Weldon Spring, Missouri. July 1997.

85. MK-Ferguson Company and Jacobs Engineering Group. Feasibility Study for Remedial Action for the Groundwater Operable Units at the Chemical Plant Area and the Ordnance Works Area, Weldon Spring, Missouri. Rev. DRAFT. DOE/OR/21548-569. Prepared for the U. S. Department of Energy, Weldon Spring Remedial Action Project and U.S. Department of the Army, Corps of Engineers. March 1998. 
86. Operational Scenario for Disposal Cell Construction Task 824, 3840-D:EN-R-02-3610-A. No date.

\section{DOE ORDERS}

5000.3B, Occurrence Reporting and Processing of Information 5400.1, General Environmental Protection Program

5400.3, Hazardous and Mixed Waste Program

5400.5, Radiation Protection of the Public and the Environment

5480.1B, Environment, Safety and Health Program for Department of Energy Operations

5480.4, Environmental Protection, Safety, and Health Protection Standards

5482.1B, Safety Analysis and Review System

5700.6C, Quality Assurance

5820.2A, Radioactive Waste Management

\section{REGULATIONS}

10 CFR 830.120, Quality Assurance

10 CFR 1022, Department of Energy, Compliance With Floodplain/Wetlands Environmental Review Requirements

36 CFR Part 800.5, Protection of Historic and Cultural Properties

40 CFR Part 61, National Emission Standards for Hazardous Air Pollutants

40 CFR Part 141, National Primary Drinking Water Regulations

40 CFR 264, Standards for Owners and Operators of Hazardous Waste Treatment, Storage, and Disposal Facilities 
APPENDIX A

Unpublished Documents

DOE/OR/21548-730, Rev. 0 


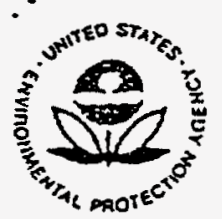

\section{UNITED STATES ENVIRONMENTAL PROTECTION AGENCY \\ REGION VII \\ 726 MINNESOTA AVENUE \\ KANSAS CITY, KANSAS 60101}

A.FF $=0 \quad 190$

Mr. Stephen H. McCracken

Project Manager

Weldon Spring site

Route 2, Highway 94 South

St. Charles, Missouri 63303

Dear Mr. McCracken:

As requested, we have reviewed the DOE "Draft Plan for Monitoring Radionuclide Emissions other Than Radon at Weldon spring Site Critical Receptors." The concept that you plan to follow meets the requirements of $40 \cdot$ C.F.R. 61 and you should proceed as planned.

Yearly determinations of airborne concentrations and assessments of effective dose equivalents at critical receptors meet the monitoring requirements of NESHAP. We also concur with your Quality Assurance Plan and the reporting plan you have set forth in the document.

When the temporary storage facility monitoring plan for radon is developed, we will be available to evaluate the draft if you so desire. Call me if I can be of any further assistance.

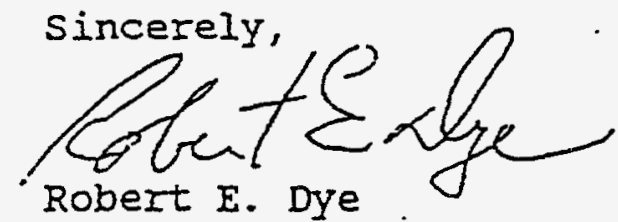

Regional Radiation Representative 


\section{Urban Infornatcion}

May 21, 1998

Mr. Eric Danielson

MK Ferguson

7295 Highway 94 South

St. Charles, MO 63304

Dear Mr. Danielson,

Following is the data you requested:

\begin{tabular}{|c|c|c|c|c|c|c|c|c|}
\hline & 1990 & 1991 & 1992 & 1993 & 1994 & 1995 & 1996 & 1997 \\
\hline $\begin{array}{l}\text { St. Charles } \\
\text { County }\end{array}$ & 212,751 & 219,330 & 225,161 & 232,989 & 239,107 & 247,860 & 255,667 & 264,275 \\
\hline $\begin{array}{l}\text { Cottleville } \\
\text { city }\end{array}$ & 453 & 485 & 509 & 581 & 774 & 911 & 1,016 & \\
\hline $\begin{array}{l}\text { Weldon Spring } \\
\text { city }\end{array}$ & 1,034 & 1,056 & 1,079 & 1,104 & 1,114 & 1,144 & 1,170 & \\
\hline $\begin{array}{l}\text { Weldon Spring } \\
\text { Heights }\end{array}$ & 97 & 97 & 97 & 98 & 96 & 96 & 95 & \\
\hline
\end{tabular}

Please call me at 516-6035 if you have any questions.

Sincerely,

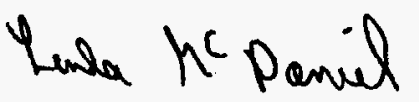

Linda C. McDaniel

Public Dala Information Specialist 
To: Shimei Xiao

From: Launa Danielson
Incoming: _ Outgoing: 1 WP\#:

Date: $3 / 12 / 98$ Time:

Conversation With:

Karl Daubel

Phone: (314) 441-8681

of: Weldon Spring Training Area - Dept. of Army

and:

Phone:

of:

Subject: Number of employees located at the U.S. Department of Army Weldon Spri Training Area

Summary of Conversation:

Karl Daubel stated the total number of employees on site is approx. 41.40 of the employees are with the contractor, Roy F. Weston. In December, 1997, the contractor mobilized, employing approximately 10 people for the month of December. Prior to December, Karl Daubel was the only employee on site.

Action of Follow-Up/Recommendations:

cc:

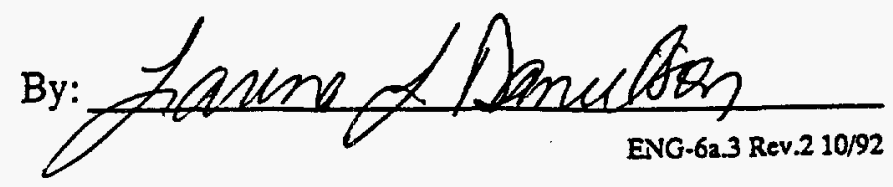


To: File/ASER

From: Shimei Xiao

Conversation With:

$$
\text { Jane Talbelt }
$$

of: Francis Howell High School Annex Personnel and:

of:

Subject: $:$ NUMBER OF STAFF AT FHHS ANNEX

Summary of Conversation:

Ms. Talbelt stated that the number of staff at Annex is approximately 38 and the average working hour is about 8 hours.
Incoming: __ Outgoing: _ WP\#:

Date: $3 / 12 / 98$ Time: $15: 15$ p.m.

Phone: $\quad$ (314) $441-0088$

Phone:

Action of Follow-Up/Recommendations:

cc: 
To: File/ASER

From: Shimei Xiao

Conversation With:

Darren May

of: St. Charles County Planning and Zoning

and:

of:

Subject: RESIDENCE AT THE QUARRY

Summary of Conversation:

Mr. May stated that the average number of people per household is approximately

2.82 person for St. Charles County.
Incoming: __ Outgoing: __ WP\#:

Date: $3 / 12 / 98$ Time: $9: 10$ a.m.

Phone: (314) 949-7335

Phone:

Action of Follow-Up/Recommendations:

By:

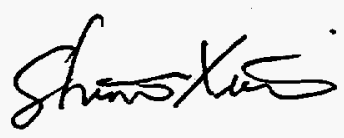


To: Shimei Xiao

From: Launa Danielson

Conversation With:

Hellen Ward

of: Francis Howell High School

and:

of:

Subject: Number of staff and students at Francis Howell High School

Summary of Conversation:

Hellen stated that the numbers for 1997 staff is approximately 180 . Student enrollment for 1997 is approximately 1850 .

Action of Follow-Up/Recommendations:

cc:

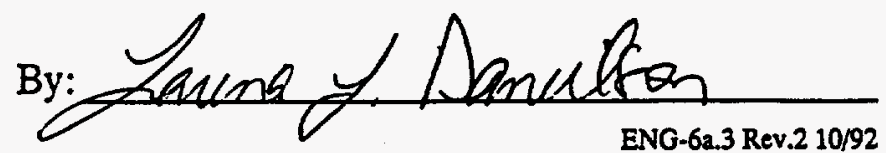


To: Shimei Xiao

From:Launa Danielson

Conversation With:

Jerry Jones

of: Mo. State Highway Department - Weldon

and:

of:

Subject: Total number of employees at the Weldon Spring Maintenance Site

Summary of Conversation:

Summary Jerry stated that nine (9) employees work out of the Weldon Spring Maintenance site of the Missouri Highway and Transportation Dept.
Incoming: _ Outgoing: $\mathrm{X}$ - WP\#:

Date: $2-26-98$ Time: 10:00 am

Phone: (314) $441-8471$
Phone:

Spring

Action of Follow-Up/Recommendations:

cc:

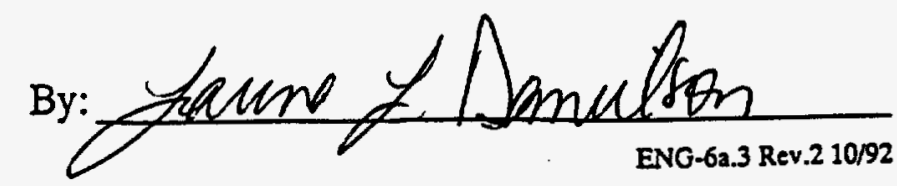


To: Shimei Xiao

From: Launa Danielson

Conversation With:

Dorothy Knoebel

of: Department of Conservation - Busch Wildilife

and:

Phone:

of:

Incoming: __ Outgoing: $\underline{\mathrm{X}}$ WP\#:

Date: $2-24-98$ Time: $2: 10$ am

Phone: (314) $441-4554$

Subject: Number of employees at the Busch Conservation Area

Summary of Conversation:

Dorothy stated the total number of employees at Busch is 40 .

Action of Follow-Up/Recommendations:

cc:

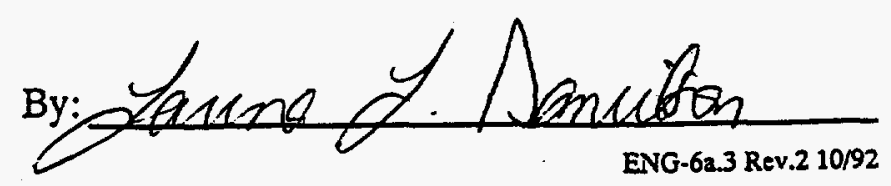


APPENDIX B

Assumptions and Scenarios for Dose Calculations 
A. Dose from the Chemical Plant and Raffinate Pits to a Maximally Exposed Individual.

The following dose assessment is for a maximally exposed individual employed full-time (2,000 hours/year) at the Missouri Highway and Transportation Department (MHTD) maintenance facility, located just northeast of the chemical plant perimeter. This scenario was developed because the environmental TLD detectors near the facility indicated a total exposure that was greater than background levels in 1997.

1. Inhalation :

a. Airborne Radioactive Particulates: Not applicable since results for all monitoring stations at the Weldon Spring Chemical Plant were indistinguishable from background levels.

b. Radon and Thoron Gas: Not applicable since annual integrated radon and $\mathrm{Rn}-220$ monitoring results were indistinguishable from the annual average background concentration.

2. External Gamma Pathway: Statistical analysis of environmental TLD results indicated that the annual exposure at station TD-2004 was greater than background (see Section 4.2). This station measured a gross annual dose equivalent of $70 \mathrm{mrem}$ $(0.70 \mathrm{mSv})$, based on 8,760 hours of continuous exposure. Given the background gamma dose equivalent of $59 \mathrm{mrem}(0.59 \mathrm{mSv})$, the net annual gamma dose equivalent was $11 \mathrm{mrem}(0.11 \mathrm{mSv})$. The effective dose equivalent (EDE) due to gamma exposure for a maximally exposed individual (MEI) at the MHTD maintenance facility is thus:

$$
\begin{aligned}
\operatorname{EDE}(\text { external) } & =\quad \begin{array}{l}
\text { (gross TLD result }- \text { background TLD result }) \mathrm{x} \\
\text { exposure time }
\end{array} \\
& =(70-59) \mathrm{mrem} / \mathrm{y} \times 2,000 \mathrm{hr} \times 1 \mathrm{y} / 8,760 \mathrm{hr} \\
& =2.5 \mathrm{mrem}(0.025 \mathrm{mSv})
\end{aligned}
$$

3. Ingestion Pathway: Because no bodies of water exist at the MHTD maintenance facility, fishing, swimming, and ingestion of contaminated water do not constitute realistic scenarios.

The total effective dose equivalent (TEDE) is therefore:

$$
\begin{aligned}
\mathrm{TEDE} & =\mathrm{EDE}(\text { external }) \\
& =2.5 \mathrm{mrem}(0.025 \mathrm{mSv})
\end{aligned}
$$


B. Dose from the Weldon Spring Quarry to a Maximally Exposed Individual

The exposure scenario for the dose estimate from the Weldon Spring Quarry is based on a hypothetical individual who hikes around the southeastern perimeter of the quarry 5 hours per year.

1. Inhalation Pathway:

a. Airborne Radioactive Particulates: Not applicable since gross alpha concentrations measured at the quarry were indistinguishable from the background average for 1997.

b. Radon and Thoron Gas: The annual average Rn-220 gas concentration measured by co-located F-type and M-type alpha-track detectors at monitoring station $\mathrm{RD}-1002$ was found to be statistically greater than the annual average background concentration. RD-1002 indicated a net $\mathrm{Rn}-220$ concentration of $0.1 \mathrm{pCi} / 1$ $\left(3.7 \mathrm{~Bq} / \mathrm{m}^{3}\right)$. A breathing rate of $20 \mathrm{lpm}$ was assumed.

Radon and thoron concentrations are often expressed in terms of working levels. One working level is defined as any combination of radon decay products in one liter of air that will result in the ultimate emission of $1.3 \mathrm{E} 5 \mathrm{MeV}$ of alpha energy. For $\mathrm{Rn}-220$, one working level (WL) is equal to $7.43 \mathrm{pCi} / 1$ at $100 \%$ equilibrium and results in a dose equivalent of $420 \mathrm{mrem}$. Realistically, however, only partial equilibrium can exist between $\mathrm{Rn}-220$ gas and its decay products, and the daughter equilibrium ratio (the parameter that is used to quantify percent equilibrium) typically does not exceed $1 \%$ in an outdoor environment. The historical daughter equilibrium ratio for Rn-220 at the WSSRAP averages $0.5 \%$ (Ref. 78). Radon and thoron exposures are typically expressed in terms of working level months (WLm), where one WLm is defined as an exposure of one WL received in one working month (170 hours).

The committed effective dose equivalent (CEDE) to the maximally exposed individual is determined by separately considering the contribution to dose from both $R n-220$ gas and $R n-220$ decay products. 


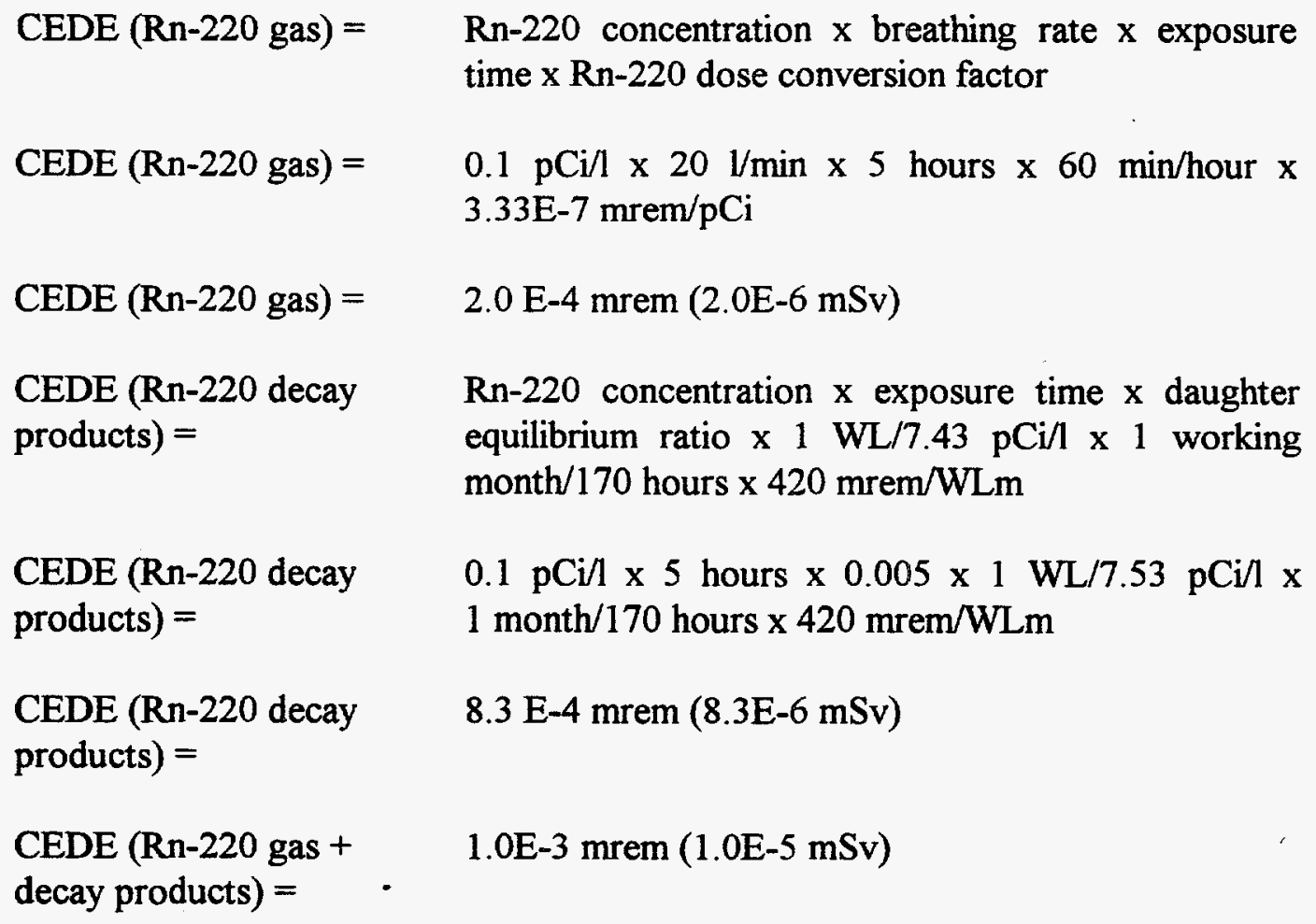

2. External Pathway: Not applicable since all environmental TLD monitoring results at the quarry were indistinguishable from background.

3. Ingestion pathway: Because the quarry is controlled by a $2.4 \mathrm{~m}(8 \mathrm{ft})$ high fence, fishing, swimming, and drinking water at the quarry do not constitute realistic scenarios.

The total effective dose equivalent (TEDE) is therefore:

$$
\begin{aligned}
& \text { TEDE = CEDE (Rn-220 gas + decay products }) \\
& =0.001 \mathrm{mrem}(1.0 \mathrm{E}-5 \mathrm{mSv})
\end{aligned}
$$

C. Dose from the Vicinity Properties to a Maximally exposed Individual

Burgermeister Spring, located at the Busch Memorial Conservation Area, contains elevated concentrations of radium, thorium, and uranium. It is assumed that an individual walked past Burgermeister Spring once a week during 1997, stopping during each visit to drink one cup $(0.2371)$ of water from the spring. Since there are 52 weeks in a year, the individual ingests 
( $52 \times 0.237$ ) liters of water, or 12.3 liters (3.24 gal). No radiological exposure is calculated for the individual for inhalation or external exposure because environmental monitoring results indicated no reason to expect that radioactive air particulate, gamma exposure, or radon levels were greater than background.

The maximum net concentrations recorded in 1997 for the radionuclides detected in Burgermeister Spring and their corresponding dose conversion factors (DCFs) for ingestion are:

\begin{tabular}{|l|l|l|}
\hline \multicolumn{1}{|c|}{ RADIONUCLIDE } & \multicolumn{1}{|c|}{$\begin{array}{c}\text { 1997 MAXIMUM } \\
\text { RECORDED CONCENTRATION } \\
\left(\mathrm{pCi} / \text { ) }^{(a)}\right.\end{array}$} & $\begin{array}{c}\text { DOSE CONVERSION FACTOR FOR } \\
\text { INGESTION (mrem/pCi) }\end{array}$ \\
\hline Total Uranium & 110 & $2.69 \mathrm{E}-4$ \\
\hline $\mathrm{Ra}-226$ & 0.40 & $1.33 \mathrm{E}-3$ \\
\hline $\mathrm{Ra}-228$ & 2.93 & $1.44 \mathrm{E}-3$ \\
\hline Th-228 & 1.08 & $3.96 \mathrm{E}-4$ \\
\hline Th-230 & 1.30 & $5.48 \mathrm{E}-4$ \\
\hline Th-232 & 0.78 & $2.73 \mathrm{E}-3$ \\
\hline $\mathrm{Ra}-224$ & 1.08 & $3.66 \mathrm{E}-4$ \\
\hline $\mathrm{Pb}-212$ & 1.08 & $4.56 \mathrm{E}-5$ \\
\hline
\end{tabular}

(a) $\mathrm{Ra}-224$ and $\mathrm{Pb}-212$ concentrations derived from measured Th-228 concentration, based on assumption of secular equilibrium

The above DCFs are derived or taken directly from EPA's Federal Guidance Report No. 11 (Ref. 28). Where multiple DCFs are listed in the guide corresponding to different intake retention factors, the most conservative DCF for that radionuclide is used.

The total effective dose equivalent (TEDE) is calculated by summing the doses contributed by each radionuclide present in the water, as shown below:

TEDE (ingestion of contaminated water) $=$ TEDE (total uranium) + TEDE (Ra-226) + TEDE $($ Ra-228) + TEDE $($ Th-228) + TEDE $($ Th-230) + TEDE (Th-232) + TEDE (Ra-224) + TEDE $(\mathrm{Pb}-212)$

and

TEDE (ingestion of contaminated water for a given radionuclide) $=$ Concentration $(\mathrm{pCi} / \mathrm{l}) \mathrm{x}$ Volume of Water Ingested (L) x Dose Conversion Factor (mrem $/ \mathrm{pCi})$

$\operatorname{TEDE}($ total uranium) $=110 \mathrm{pCi} / 1 \times 12.31 \times 2.69 \mathrm{E}-4 \mathrm{mrem} / \mathrm{pCi}$

TEDE (total uranium) $=0.36 \mathrm{mrem}$

$\operatorname{TEDE}(\mathrm{Ra}-226)=0.40 \mathrm{pCi} / \mathrm{l} \times 12.31 \times 1.33 \mathrm{E}-3 \mathrm{mrem} / \mathrm{pCi}$ 
TEDE $(\operatorname{Ra}-226)=0.0065$ mrem

$\operatorname{TEDE}(\operatorname{Ra}-228)=2.93 \mathrm{pCi} / \mathrm{l} \times 12.31 \times 1.44 \mathrm{E}-3 \mathrm{mrem} / \mathrm{pCi}$

TEDE $(\operatorname{Ra}-228)=0.052$ mrem

TEDE $($ Th-228) $=1.08 \mathrm{pCi} / 1 \times 12.31 \times 3.94 \mathrm{E}-4 \mathrm{mrem} / \mathrm{pCi}$

TEDE $(\mathrm{Th}-228)=0.0052 \mathrm{mrem}$

$\operatorname{TEDE}(\mathrm{Th}-230)=1.30 \mathrm{pCi} / 1 \times 12.31 \times 5.48 \mathrm{E}-4 \mathrm{mrem} / \mathrm{pCi}$

TEDE $($ Th-230 $)=0.0088$ mrem

$\operatorname{TEDE}(\mathrm{Th}-232)=0.78 \mathrm{pCi} / 1 \times 12.31 \times 2.73 \mathrm{E}-3 \mathrm{mrem} / \mathrm{pCi}$

TEDE $($ Th-232 $)=0.026$ mrem

$\operatorname{TEDE}(\mathrm{Ra}-224)=1.08 \mathrm{pCi} / 1 \times 12.31 \times 3.66 \mathrm{E}-3 \mathrm{mrem} / \mathrm{pCi}$

TEDE $(\mathrm{Ra}-224)=0.0049 \mathrm{mrem}$

$\operatorname{TEDE}(\mathrm{Pb}-212)=1.08 \mathrm{pCi} / \mathrm{l} \times 12.31 \times 4.56 \mathrm{E}-5 \mathrm{mrem} / \mathrm{pCi}$

TEDE $(\mathrm{Pb}-212)=0.0006$ mrem

Thus, the TEDE for all radionuclides combined is $(0.36+0.0065+0.052+0.0052+0.0088+$ $0.026+0.0049+0.0006)$ mrem, or $0.46 \mathrm{mrem}(4.6 \mathrm{E}-3 \mathrm{mSv})$.

D. Collective Population Dose Estimate

Exposure points are locations where members of the public are potentially being exposed to above-background concentrations of (1) airborne radioactive particulates, (2) radon gas concentrations, (3) external gamma radiation, or (4) radionuclides in food or water. All four pathways are addressed for the collective population dose estimate. Exposure to abovebackground radionuclide concentrations in food or water is applicable only for users of the Busch Conservation Area, a recreational area adjacent to the chemical plant/raffinate pits area.

Exposure points, by definition, must be located where there is potential for public exposure as a result of activities performed at the site or from materials stored at the site. If there is no reason to suspect that environmental monitoring results are different from the appropriate 
background monitoring results, then the area surrounding the environmental monitoring station cannot be considered an exposure point. Therefore, the population near that station, as well as the population beyond the station, would not be included in the collective population dose estimate.

A collective population dose assessment is performed at the exposure points where the above background environmental monitoring results are obtained and a potential for public exposure is suspected. All four pathways are addressed for this estimate.

\section{Airborne Radioactive Particulates}

In 1997, annual average airborne radionuclide concentrations (as measured by high volume monitors) at all critical receptor locations were indistinguishable from background. However, a statistical analysis of low volume monitoring results indicated that, at the $95 \%$ confidence level, four chemical plant perimeter locations had ambient gross alpha concentrations that were greater than background. Only one of these stations, AP-2005, is in an area likely to be frequented by members of the public. Station AP-2005 is located next to the WSSRAP Administration Building, where approximately 300 employees work an average of about 2,500 hours per year. Technically, because the area is under DOE control, these individuals are not considered members of the public, but are treated as such for purposes of determining a collective population dose equivalent.

The annual gross alpha concentration at Station AP-2005 was $0.25 \mathrm{E}-15 \mu \mathrm{Ci} / \mathrm{ml}(0.25 \mathrm{E}-$ $3 \mathrm{pCi} / \mathrm{m}^{3}$ )above background. To determine a dose equivalent for an individual at the Administration Building, a breathing rate of $1.2 \mathrm{~m}^{3}$ per hour is assumed. Based on information obtained from the Buildings Radiological Characterization Report (Ref. 79) it is assumed that the gross alpha concentration at AP-2005 is contributed entirely by total uranium. Therefore, the resulting collective population dose equivalent due to inhalation of radioactive airborne particulates is:

Collective Population Dose Equivalent (inhalation of air particulates) $=$ Gross alpha concentration above background $\left(\mathrm{pCi} / \mathrm{m}^{3}\right) \times$ Exposure time (hours) $\times$ Breathing rate $\left(\mathrm{m}^{3} /\right.$ hour $) \times$ Dose equivalent conversion factor for inhalation of total uranium $(\mathrm{mrem} / \mathrm{pCi})$ $x$ number of individuals

$=0.25 \mathrm{E}-3 \mathrm{pCi} / \mathrm{m}^{3} \times 2,500$ hours $\times 1.2 \mathrm{~m}^{3} /$ hour $\times 0.124 \mathrm{mrem} / \mathrm{pCi} \times 300$ persons $\mathrm{x}$ $1 \mathrm{E}-3 \mathrm{rem} / \mathrm{mrem}$

$=0.028$ person-rem ( $2.8 \mathrm{E}-4$ person-Sv)

2. Radon/Thoron Gas Exposures 
Statistical analysis of annual integrated radon ( $\mathrm{Rn}-220$ and $\mathrm{Rn}-222)$ alpha track monitoring results indicated that all critical receptor stations had concentrations that were indistinguishable from the annual average background concentration. Station RD-1002 at the quarry upper rim, however, had an annual average $\mathrm{Rn}-220$ concentration that was slightly above background. This area was eliminated from consideration for a collective population dose equivalent because no significant number of people abide or reside there. Also, three chemical plant perimeter radon monitoring stations had elevated annual average integrated radon concentrations. Similarly, the same three monitoring stations, RD-3001, 3002, and 3003, indicated elevated annual Rn-220 concentrations. However, since these stations are not located near a significant off-site population, they, too, were eliminated from further consideration for purposes of determining a collective population dose equivalent.

Thus, inhalation of $\mathrm{Rn}-222$ and $\mathrm{Rn}-220$ gas and decay products is not considered to be a contributor to the collective population dose equivalent for 1997.

\section{External Gamma Pathway}

The only above-background gamma monitoring location likely to be frequented by members of the public in 1997 was Station TD-2004, located near the MHTD facility. As shown in Section A, Part 2 of this Appendix, the effective dose equivalent (EDE) due to gamma exposure for a MEI at the MHTD maintenance facility is $2.5 \mathrm{mrem}(0.025 \mathrm{mSv})$.

Since nine full time employees work at the facility, the collective population dose equivalent due to gamma exposure is:

Population Dose equivalent

$\begin{aligned} \text { (gamma exposure) } & =2.5 \text { mrem } \times 9 \text { persons } \times 1 \mathrm{rem} / 1,000 \mathrm{mrem} \\ & =\quad \text { person-rem } \\ & =0.023 \text { person-rem }(2.3 \mathrm{E}-4 \text { person-Sv) }\end{aligned}$

4. Ingestions of Food or Water

Exposure to above-background radionuclide concentrations in food or water by a significant human population is applicable only for visitors to the Busch Conservation Area, a recreational area adjacent to the chemical plant/raffinate pits area. Three of the lakes at the area (i.e., Lakes 34, 35, and 36) receive runoff from the Weldon Spring site and are used for fishing and boating activities. The Missouri Department of Conservation conducted a year long survey to determine the number of visitors to the area, the types of activities in which users participate, and the amount of time allocated for these activities 
(Ref. 30).

Fishing at the Busch Conservation Area averaged 2.5 hours per visit for the approximately 160,000 visits to the area for that purpose (assuming a fish-caught to time-spent ratio of 0.4 fish/hour and a 0.50 ratio of fish kept to fish caught for a total of 80,000 fish). Assuming that one person keeps one fish, the population of concern would be 80,000 persons. For the water and sediment ingestion scenarios, boating is the activity assumed to provide the potential for incidental water and sediment ingestion. An estimated 5,985 visits were made for the purpose of boating with an average of 5.7 hours per visit. Assuming that each visit constitutes one individual, the total population would be 5,985 persons. Each of these ingestion scenarios is further addressed in calculations $\mathrm{a}, \mathrm{b}$, and $\mathrm{c}$ below.

a. Dose estimate due to ingestion of fish obtained at the Busch Memorial Conservation Area.

- Assuming that each person of the 80,000 population consumes one fish and that the edible portion of a fish has a mass of $200 \mathrm{~g}$, the average consumption rate specific to the affected population is $0.55 \mathrm{~g} /$ person/day.

- Fish samples were last collected in 1996 as part of the WSSRAP biological monitoring program. Using the 1996 total uranium concentration of $0.019 \mathrm{pCi} / \mathrm{g}$ obtained from a composite of sunfish samples collected in Lake 35 and the population specific consumption rate derived from Missouri Department of Conservation data, the estimated population dose equivalent is:

Population Dose Equivalent (fish ingestion)

$=\quad$ consumption rate $\mathrm{x}$ total uranium concentration in fish $\mathrm{x}$ exposure time $\mathrm{x}$ total uranium dose conversion factor $x$ persons

$=\quad 0.55 \mathrm{~g} /$ day $\times 0.019 \mathrm{pCi} / \mathrm{g} \times 365$ day $\times 2.69 \mathrm{E}-4 \mathrm{mrem} / \mathrm{pCi} \times 80,000$ persons $\times$ $1 \mathrm{rem} / 1,000 \mathrm{mrem}$

$=\quad 0.082$ person-rem $(8.2 \mathrm{E}-4$ person-Sv)

b. Dose estimate due to incidental ingestion of water at the Busch Conservation lakes: 
- $\quad$ Assume that each person of the 5,985 population makes one boating visit on an annual basis and $5 \%$ of the visit is spent swimming ( 0.285 hours/visit).

- Using the maximum total uranium surface water content of $10.4 \mathrm{pCi} / /$ obtained from Lake 35 in 1997, and an ingestion rate of $0.051 /$ hour (Ref. 30 ) the estimated population dose equivalent is

Population Dose Equivalent (water ingestion)

$=\quad$ ingestion rate $\mathrm{x}$ total uranium concentration in surface water $\mathrm{x}$ exposure time $\mathrm{x}$ dose conversation factor $x$ number of individuals

$=\quad 0.051 / \mathrm{hr} \times 10.4 \mathrm{pCi} / 1 \times 0.285 \mathrm{hr} \times 2.69 \mathrm{E}-4 \mathrm{mrem} / \mathrm{pCi} \times 5,985$ persons $\times$ $1 \mathrm{rem} / 1,000 \mathrm{mrem}$

$=\quad 0.00024$ person-rem $(2.4 \mathrm{E}-6$ person-Sv)

c. Dose estimate due to ingestion of sediments at the Busch lakes:

- $\quad$ Assume that each person of the 5,985 population makes one boating visit on an annual basis and 5\% of the visit is spent swimming ( 0.285 hours/visit).

- $\quad$ Using the average total uranium concentration of $26.6 \mathrm{pCi} / \mathrm{g}$ in sediment obtained from Lake 35 as part of a 3-year study (spanning 1991-94), (Ref. 15) and an ingestion rate of $200 \mathrm{mg} /$ day, the estimated population dose equivalent is:

Population Dose Equivalent (sediment ingestion)

$=\quad$ ingestion rate $\mathrm{x}$ total uranium concentration in sediment $\mathrm{x}$ exposure time $\mathrm{x}$ dose conversion factor $\mathrm{x}$ number of individuals

$=\quad 200 \mathrm{mg} /$ day $\times 26.6 \mathrm{pCi} / \mathrm{g} \times 0.285 \mathrm{hr} /$ person $\times 2.69 \mathrm{E}-4 \mathrm{mrem} / \mathrm{pCi} \times 5,985$ persons $\times$ $1 \mathrm{~g} / 1,000 \mathrm{mg} \times 1 \mathrm{day} / 24 \mathrm{hr} \times 1 \mathrm{rem} / 1,000 \mathrm{mrem}$

$=\quad 0.0001$ person-rem $(1.0 \mathrm{E}-6$ person-Sv)

Therefore, the collective population dose equivalent obtained from ingestion of food or water at the Busch Memorial Conservation Area is: 
Dose (fish ingestion) + Dose (water ingestion) + Dose (sediment ingestion)

$$
\begin{array}{ll}
= & 0.082+0.00024+0.0001 \text { person-rem } \\
= & 0.082 \text { person-rem }(8.2 \mathrm{E}-4 \text { person-Sv })
\end{array}
$$

The 1997 total collective population dose equivalent for all applicable pathways addressed in this section is:

Dose (airborne particulates) + Dose (gamma exposure) + Dose (ingested food and water)

$$
\begin{array}{ll}
= & 0.028+0.023+0.082 \\
= & 0.13 \text { person-rem }(1.3 \mathrm{E}-3 \text { person-Sv })
\end{array}
$$

\section{E. Airborne Radioactive Release Estimates}

During 1997, statistical analysis of annual average high volume monitoring results indicated no locations where airborne radionuclide concentrations were greater than background. However, four low volume monitoring stations along the chemical plant perimeter indicated annual average concentrations that were statistically greater than the 104-week average background concentration. These stations were AP-2002, 3003, 3004, and 2005. The net annual average gross alpha concentrations at these stations were incorporated into a series of box models to estimate the total radioactive airborne particulate release from the site for 1997. Table B-1 summarizes the approximate activity ratios for the radionuclides contained in the waste common to each area of the site where an elevated annual average concentration was documented (see Section 4). The table also identifies the sources believed to be responsible for each station that indicated elevated readings for the year.

The box model approach provides conservative results and is used in place of Gaussian plume dispersion modeling, which is generally inappropriate for estimating ambient pollutant concentrations at receptors close to a source, which is the case for the perimeter monitors at the WSSRAP. Parameters required for inclusion in the box models include: net average gross alpha concentration (listed in Table B-1); the range of wind directions (measured out from the source) encompassing the area in which a given monitoring station is located, including the average wind speed and directional frequency (percentage of time that the wind blew toward those directions) for that range; the estimated release height at the fence line; and the box length, which is the distance between two points along the fence line drawn on either side of a monitoring station. (These two points are the midpoints between a given monitoring station and the next closest station along the site perimeter.) Table B-2 summarizes the parameters and assumptions used in the modeling.

The radioactive particulate release rate from the chemical plant is estimated by applying the following equation for each monitoring station result: 
Release Rate $(\mathrm{Ci} / \mathrm{y})=\Sigma_{\mathrm{i}} \Sigma_{\mathrm{j}}[$ Box Length $(\mathrm{m}) \times$ Release Height $(\mathrm{m}) \times$ Wind Speed $(\mathrm{m} / \mathrm{s}) \times$ Net Annual Gross Alpha Concentration $\left(\mathrm{Ci} / \mathrm{m}^{3}\right)$ x 3.1536 E7 sec/y x Directional Frequency]

where $\mathrm{i}=$ monitoring station

and $\mathrm{j}=$ radionuclide

For example, for Station AP-2002, the total release rate is determined as follows:

Total Radioactive Airborne Particulate Release Rate $(\mathrm{AP}-2002)=610 \mathrm{~m} \mathrm{x} 3 \mathrm{~m} \mathrm{x} 2.8 \mathrm{~m} / \mathrm{s} \times 0.19$ $\mathrm{E}-15 \mathrm{Ci} / \mathrm{m}^{3} \times 3.1536 \mathrm{E} 7 \mathrm{sec} / \mathrm{y} \times 0.369$

Total Radioactive Airborne Particulate Release Rate $($ AP-2002) $=1.13 \mathrm{E}-5 \mathrm{Ci} / \mathrm{y}$

The radionuclide-specific airborne particulate release rates based on annual results from Station AP-2002 are subsequently determined by multiplying the total AP-2002 release rate by each activity ratio listed in Table B-1 for the contributing source. Radionuclide-specific activity releases calculated for all monitoring stations are shown in Table B-3. The total activity release for each radionuclide released from the chemical plant area is found by summing the results in each column of the table.

Table B-1 Sources and Activity Ratios Corresponding to Elevated Gross Alpha Concentrations at Perimeter Low Volume Monitoring Stations

\begin{tabular}{|c|c|c|c|c|c|c|c|c|c|c|}
\hline \multirow[t]{2}{*}{$\begin{array}{c}\text { Station } \\
\text { ID }\end{array}$} & \multirow{2}{*}{$\begin{array}{c}\text { Net } \\
\text { Concentration } \\
\text { Above } \\
\text { Background } \\
(\mu \mathrm{Ci} / \mathrm{mL}) \\
\end{array}$} & \multirow[t]{2}{*}{$\begin{array}{l}\text { WSSRAP Source } \\
\text { Contributing to } \\
\text { Elevated } \\
\text { Concentrations }\end{array}$} & \multicolumn{8}{|c|}{ Activity Ratios } \\
\hline & & & U-234 & U-235 & $\mathrm{U}-238$ & Th-228 & Th-230 & Th-232 & Ra-226 & Ra-228 \\
\hline AP-2002 & $0.19 E-15$ & $\begin{array}{l}\text { Ash Pond - CMSA } \\
\text { and Foundation } \\
\text { Removal Soils }\end{array}$ & 0.416 & 0.018 & 0.411 & 0.053 & 0.052 & 0.049 & N/A & N/A \\
\hline AP-3003 & $0.62 E-15$ & Raffinate Pit 4 & 0.130 & 0.010 & 0.120 & 0.070 & 0.61 & 0.070 & N/A & N/A \\
\hline AP-3004 & $0.39 E-15$ & TSA & 0.069 & 0.003 & 0.064 & 0.022 & 0.752 & 0.036 & 0.052 & 0.040 \\
\hline AP-2005 & $0.25 E-15$ & $\begin{array}{l}\text { WSCP Area } \\
\text { Building } \\
\text { Foundations and } \\
\text { Underlying } \\
\text { Contaminated } \\
\text { Soils }\end{array}$ & 0.491 & 0.023 & 0.486 & N/A & N/A & N/A & N/A & N/A \\
\hline
\end{tabular}


Table B-2 Parameters and Assumptions Used in Box Modeling to Determine Radioactive Airborne Particulate Release Rate from the WSSRAP for 1997

\begin{tabular}{|c|c|c|c|c|c|c|}
\hline Box Model & $\begin{array}{c}\text { Monitoring } \\
\text { Station }\end{array}$ & $\begin{array}{c}\text { Range of Wind } \\
\text { Directions (Wind } \\
\text { Blowing From) }\end{array}$ & $\begin{array}{c}\text { Average Wind } \\
\text { Speed for Range } \\
(\mathrm{m} / \mathrm{s})\end{array}$ & $\begin{array}{c}\text { Directional } \\
\text { Frequency }\end{array}$ & $\begin{array}{c}\text { Box Length } \\
(\mathrm{m})\end{array}$ & $\begin{array}{c}\text { Release Height } \\
(\mathrm{m})\end{array}$ \\
\hline 1 & AP-2002 & $\begin{array}{c}326.25^{\circ}-67.5^{\circ} \\
(\mathrm{SSE}, \mathrm{S}, \mathrm{SSW}, \mathrm{SW} \\
\text { WSW) }\end{array}$ & 2.8 & $36.9 \%$ & 610 & 3 \\
\hline 2 & AP-3003 & $\begin{array}{c}168.75^{\circ}-191.25^{\circ} \\
(\mathrm{S})\end{array}$ & 2.9 & $9.5 \%$ & 488 & 3 \\
\hline 3 & AP-3004 & $\begin{array}{c}78.75^{\circ}-123.75^{\circ} \\
(\mathrm{E}, \mathrm{ESE})\end{array}$ & 2.0 & $7.2 \%$ & 610 & 3 \\
\hline 4 & AP-2005 & $\begin{array}{c}281.25^{\circ}-33.75^{\circ} \\
\text { (WNW-NNE) }\end{array}$ & 3.4 & $33.1 \%$ & 762 & 3 \\
\hline
\end{tabular}


Table B-3 Radionuclide-Specific Activity Release Rates Corresponding to Monitoring Stations with Gross Alpha Results Greater Than Background for 1997

\begin{tabular}{|c|c|c|c|c|c|c|c|c|c|}
\hline \multirow[t]{2}{*}{ Station } & \multirow{2}{*}{$\begin{array}{c}\text { Total Activity } \\
\text { Release } \\
\text { (Ci/y) }\end{array}$} & \multicolumn{8}{|c|}{ Release Rates } \\
\hline & & $U-234$ & U-235 & $U-238$ & Th-228 & Th-230 & Th-232 & $\mathrm{Ra}-226$ & $\operatorname{Ra}-228$ \\
\hline AP-2002 & $1.13 \mathrm{E}-05$ & $4.71 E-06$ & $2.04 E-07$ & $4.66 E-06$ & $6.00 E-07$ & 5.89E-07 & 5.55E-07 & $\overline{N / A}$ & N/A \\
\hline AP-3003 & $7.89 E-06$ & $1.03 E-06$ & $7.89 E-08$ & $9.46 E-07$ & 5.52E-07 & $4.81 E-06$ & $5.52 E-07$ & $\bar{N} / \mathrm{A}$ & N/A \\
\hline AP-3004 & $3.24 \mathrm{E}-06$ & $2.24 E-07$ & $9.72 E-09$ & 2.07E-07 & 7.13E-08 & $2.44 E-06$ & 1.17E-07 & 1.69E-07 & 1.30E-07 \\
\hline AP-2005 & $2.03 E-05$ & $9.96 \mathrm{E}-06$ & 4.67E-07 & $9.86 E-06$ & N/A & N/A & N/A & $\overline{N / A}$ & N/A \\
\hline \multicolumn{2}{|c|}{ Total Release Rates } & $1.59 \mathrm{E}-5$ & $7.59 \mathrm{E}-7$ & 1.57E-5 & $\overline{1.22 \mathrm{E}-6}$ & $\overline{7.84 E-6}$ & $1.22 \mathrm{E}-6$ & $1.69 \mathrm{E}-7$ & $1.30 \mathrm{E}-7$ \\
\hline
\end{tabular}

\section{F. Radon-220 and Radon-222 Release Estimates}

Annual average $\mathrm{Rn}-222$ and $\mathrm{Rn}-220$ concentrations at chemical plant track etch perimeter monitoring stations were calculated based on the results of paired F-type and M-type detectors. The results indicated that $\mathrm{Rn}-222$ levels at all perimeter stations were indistinguishable from background, while $R n-220$ levels were statistically greater than background at perimeter stations $\mathrm{RD}-3001, \mathrm{RD}-30002$, and $\mathrm{RD}-3003$ located along the western chemical plant perimeter. The annual average $\mathrm{Rn}-220$ concentrations at these three stations were $1.9,0.7$, and $0.7 \mathrm{pCi} / 1$, respectively, above the combined background concentration of $0.1 \mathrm{pCi} / 1$ for the year (see Section 4, Table 4-2). A series of three box models was used to calculate the total $R n-220$ release rate from the chemical plant based on these results, assuming that the major source of $\mathrm{Rn}-220$ emissions at the chemical plant during 1997 was Raffinate Pit 4 (based on an assessment of sludge consolidation activities and site-wide radon measurements performed during 1997).

Parameters required for inclusion in the box models include: net average $\mathbf{R n}-220$ concentration; the range of wind directions (measured out from the source) encompassing the area in which a given monitoring station is located, including the average wind speed and directional frequency (percentage of time the wind blew in those directions) for that range; the estimated $\mathrm{Rn}-220$ release height at the fence line; and the box length, which is the distance between two points along the fence line drawn on either side of a monitoring station. (These two points are the midpoints between a given monitoring location and the next closest station along the site perimeter.) Table B-4 provides a summary of the parameters and assumptions used in the modeling scheme. 
Table B-4 Parameters and Assumptions Used in Box Modeling to Determine Rn-220 Release Rate from the WSSRAP for 1997

\begin{tabular}{|c|c|c|c|c|c|c|c|}
\hline $\begin{array}{c}\text { BOX } \\
\text { MODEL }\end{array}$ & $\begin{array}{l}\text { MONITORING } \\
\text { STATION }\end{array}$ & $\begin{array}{l}\text { RANGE OF WIND } \\
\text { DIRECTIONS } \\
\text { (WIND BLOWING } \\
\text { FROM) }\end{array}$ & $\begin{array}{l}\text { AVERAGE } \\
\text { WIND } \\
\text { SPEED } \\
\text { FOR } \\
\text { RANGE } \\
\text { (m/s) }\end{array}$ & $\begin{array}{l}\text { DIRECTIONAL } \\
\text { FREQUENCY }\end{array}$ & $\begin{array}{l}\text { BOX } \\
\text { LENGTH } \\
\text { (m) }\end{array}$ & $\begin{array}{l}\text { RELEASE } \\
\text { HEIGHT } \\
\text { (m) }\end{array}$ & $\begin{array}{c}\text { NET Rn-220 } \\
\text { CONCENTRATIO } \\
\text { N (Pci/l) }\end{array}$ \\
\hline \multicolumn{8}{|c|}{ WELDON SPRING CHEMICAL PLANT } \\
\hline 1 & RD-3001 & $\begin{array}{c}168.75^{\circ}-141.25^{\circ} \\
\text { (S) }\end{array}$ & 2.9 & $9.5 \%$ & 488 & 3 & 1.9 \\
\hline 2 & RD-3002 & $\begin{array}{c}45^{\circ}-146.25^{\circ} \\
(\mathrm{NE}-\mathrm{SE})\end{array}$ & 2.3 & $20.2 \%$ & 305 & $\overline{3}$ & 0.7 \\
\hline 3 & RD-3003 & $\begin{array}{c}348.75^{\circ}-45^{\circ} \\
(\mathrm{N}-\mathrm{NE})\end{array}$ & 3.0 & $14.1 \%$ & 274 & 3 & 0.7 \\
\hline \multicolumn{8}{|c|}{ WELDON SPRING QUARRY } \\
\hline 4 & RD-1002 & $\begin{array}{c}258.75^{\circ}-303.75^{\circ} \\
\text { (W-WNW) }\end{array}$ & 4.1 & $13.7 \%$ & 80 & 3 & 0.1 \\
\hline
\end{tabular}

The following calculation is used to estimate the $\mathrm{Rn}-220$ release rate from the chemical plant for each model:

Release Rate $(\mathrm{Ci} / \mathrm{y})=$ Box Length $(\mathrm{m}) \times$ Release Height $(\mathrm{m}) \times$ Average Wind Speed $(\mathrm{m} / \mathrm{s}) \times$ Net Rn-220 Concentration (pCi/) $\times 1 \mathrm{E}-12 \mathrm{Ci} / \mathrm{pCi} \times 1,0001 / \mathrm{m}^{3} \times 3.1536 \mathrm{E} 7 \mathrm{~s} / \mathrm{y} \times$ Directional Frequency

\section{Box Model 1 (RD-3001):}

Release Rate $=488 \mathrm{~m} \mathrm{x} 3 \mathrm{~m} \times 2.9 \mathrm{~m} / \mathrm{s} \times 1.9 \mathrm{pCi} / 1 \times 1 \mathrm{E}-12 \mathrm{Ci} / \mathrm{pCi} \times 1,000 \mathrm{l} / \mathrm{m}^{3} \times 3.1536 \mathrm{E} 7 \mathrm{~s} / \mathrm{y} \times$ 0.095

Release Rate $(\mathrm{RD}-3001)=24.2 \mathrm{Ci} / \mathrm{y}(8.95 \mathrm{E} 11 \mathrm{~Bq} / \mathrm{y})$

\section{Box Model 2(RD-3002):}

Release Rate $=305 \mathrm{~m} \times 3 \mathrm{~m} \times 2.3 \mathrm{~m} / \mathrm{s} \times 0.7 \mathrm{pCi} / 1 \times 1 \mathrm{E}-12 \mathrm{Ci} / \mathrm{pCi} \times 1,000 \mathrm{1} / \mathrm{m}^{3} \times 3.1536 \mathrm{E} 7 \mathrm{~s} / \mathrm{y} \times$ 0.202

Release Rate $(\mathrm{RD}-3002)=9.4 \mathrm{Ci} / \mathrm{y}(3.48 \mathrm{E} 11 \mathrm{~Bq} / \mathrm{y})$

Box Model 3 (RD-3003):

Release Rate $=274 \mathrm{~m} \times 3 \mathrm{~m} \times 3.0 \mathrm{~m} / \mathrm{s} \times 0.7 \mathrm{pCi} / 1 \times 1 \mathrm{E}-12 \mathrm{Ci} / \mathrm{pCi} \times 1,0001 / \mathrm{m}^{3} \times 3.1536 \mathrm{E} 7 \mathrm{~s} / \mathrm{y} \times$ 0.141

Release Rate $(\mathrm{RD}-3003)=7.7 \mathrm{Ci} / \mathrm{y}(2.85 \mathrm{E} 11 \mathrm{~Bq} / \mathrm{y})$ 
The total estimated $\mathrm{Rn}-220$ release rate from the chemical plant area is the sum of the results of the 3 box models, or approximately $41.3 \mathrm{Ci} / \mathrm{y}(1.53 \mathrm{E} 12 \mathrm{~Bq} / \mathrm{y})$.

\section{Weldon Spring Quarry}

Based on the annual results of paired F-type and M-type alpha-track detectors, Station RD-1002 was found to exceed the annual average $\mathrm{Rn}-220$ background concentration by $0.1 \mathrm{pCi} / \mathrm{L}$. Station RD-1002 is located in the quarry upper rim area, along the northeastern quarry perimeter.

Residual thorium contamination is known to exist near this station, and was considered to be the source of this slightly elevated concentration. As for the stations with elevated Rn-220 concentrations along the chemical plant perimeter, a box model was developed for the quarry to estimate the $\mathrm{Rn}-220$ release from the quarry for 1997 . The parameters used in the box model are summarized in Table B-4. Applying the same equation as was previously used to determine the $R n-220$ chemical plant release, the $R n-220$ release rate is determined for the quarry:

Release Rate $(\mathrm{Ci} / \mathrm{y})=$ Box Length $(\mathrm{m}) \times$ Release Height $(\mathrm{m}) \times$ Average Wind Speed $(\mathrm{m} / \mathrm{s}) \times$ Net Rn-220 Concentration (pCi/L) x 1E-12 Ci/pCi $\times 1,000 \mathrm{~L} / \mathrm{m}^{3} \times 3.1536 \mathrm{E} 7 \mathrm{~s} / \mathrm{y} \times$ Directional Frequency

Release Rate $(\mathrm{RD}-1002)=80 \mathrm{~m} \times 3 \mathrm{~m} \times 4.1 \mathrm{~m} / \mathrm{s} \times 0.1 \mathrm{pCi} / \mathrm{L} \times 1 \mathrm{E}-12 \mathrm{Ci} / \mathrm{pCi} \times 1,000 \mathrm{~L} / \mathrm{m}^{3} \times$ $3.1536 \mathrm{E} 7 \mathrm{~s} / \mathrm{y} \times 0.137$

Release Rate $(\mathrm{RD}-1002)=0.43 \mathrm{Ci} / \mathrm{y}$

Thus, the total $R n-220$ release from the Weldon Spring Site for 1997 is the sum of the chemical plant and quarry releases, or $41.7 \mathrm{Ci}(1.54 \mathrm{E} 12 \mathrm{~Bq})$. 


\section{APPENDIX C}

Distribution List 


\section{DISTRIBUTION LIST}

\section{FEDERAL - ELECTED OFFICIALS:}

The Honorable John Ashcroft

U.S. Senate

SR-170 Russell Senate Office Building

Washington, D.C. 20510

Ms. Amy White

U.S. Senator John Ashcroft

8000 Maryland Avenue Sutie 1080

St. Louis, Missouri 63101

The Honorable Christopher S. Bond

U.S. Senate

SR-293 Russell Senate Office Building

Washington, D.C. 202-224-5721

Ms. Catherine Hanoway

U.S. Senator Christopher S. Bond

8000 Maryland Avenue Suite 1080

St. Louis, Missouri 63101

The Honorable Richard Gephardt

U.S. Representatives

1226 Longworth House of Representatives

Washington, D.C. 20515-2503

Ms. Mary Renick

Administrative Assistant

U.S. Representative Gephardt

11140 South Town Square Suite 201

St. Louis, Missouri 63123

The Honorable Denny Hulshof

U.S. Representatives

1728 Longworth House of Representatives

Washington, D.C. 20515 
U.S. Representative Denny Hulshof

33 Broadway Street Suite 280

Columbia, Missouri 65203

The Honorable James $M$. Talent

U.S. Representatives

1022 Longworth House

Washington, D.C. 20515-2502

Ms. Barbara Cooper, District Director

U.S. Representative James M. Talent

555 N. New Ballas Road Suite 315

St. Louis, Missouri 63141

The Honorable William L. Clay

U.S. House of Representatives

2306 Rayburn House Office Building

Washington, D.C. 20515-2501

Ms. Pearlie Evans, District Assistant

U.S. Representative William L. Clay

6197 Delmar Avenue

St. Louis, Missouri 63112

\section{STATE - ELECTED OFFICIALS (by district)}

The Honorable Mel Carnahan, Governor

State of Missouri

216 State Capitol Building

P.O. Box 270

Jefferson City, Missouri 65102

The Honorable Ted House

D-2nd District

Missouri State Senator

Room 227, State Capitol Bldg.

Jefferson City, Missouri 65101 
The Honorable Steve Ehlmann

R-23rd District St. Charles

Missouri State Senator

Room 421, State Capitol Bldg.

Jefferson City, Missouri 65101

The Honorable William Leutkenhaus

D-12th District Josephville

Missouri House of Representatives

Room 233A, State Capitol Bldg.

Jefferson City, Missouri 65101

The Honorable Harriet Brown

R-13th District Wentzville

Missouri House of Representatives

Room 105J

House Post-Office

State Capitol Building

Jefferson City, Missouri 65101-6806

The Honorable Cindy Ostmann

R-14th District St. Peters

Missouri House of Representatives

Room 115-F, State Capitol Bldg.

Jefferson City, Missouri 65101

The Honorable Jon Bennett

D-15th District St. Charles

Missouri House of Representatives

Room 109-E, State Capitol Bldg.

Jefferson City, Missouri 65101

The Honorable Rich Chrismer

R-16th District St. Peters

Missouri House of Representatives

Room 101-I, State Capitol Bldg.

Jefferson City, Missouri 65101 
The Honorable Don R. Kissell

D-17th District St. Peters

Missouri House of Representatives

Room 101-E, State Capitol Bldg.

Jefferson City, Missouri 65101

The Honorable Charles Gross

R-18th District St. Charles

Room 116-I, State Capitol Bldg.

Jefferson City, Missouri 65101

COUNTY - St. Charles County Government (by district)

The Honorable Joe Ortwerth

County Executive

St. Charles County Courthouse

100 North Third Street Suite 318

St. Charles, Missouri 63301

The Honorable William R. Gatewood

District \#1, County Council

St. Charles County Courthouse

100 North Third Street

St. Charles. Missouri 63301

The Honorable Shirley Sisco

District \#2, County Council

St. Charles County Courthouse

100 North Third Street

St. Charles, Missouri 63301

The Honorable Robert Schnur

District \#3, County Council

St. Charles County Courthouse

100 North Third Street

St. Charles, Missouri 63301 
The Honorable Harold Kohrs

District \#4, County Council

St. Charles County Courthouse

100 North Third Street

St. Charles, Missouri 63301

The Honorable Sally A. Faith

District \#5, County Council

St. Charles County Courthouse

100 North Third Street

St. Charles, Missouri 63301

The Honorable Dan Foust

District \#6, County Council

St. Charles County Courthouse

100 North Third Street

St. Charles, Missouri 63301

The Honorable Carl L. Bearden

District \#7, County Council

St. Charles County Courthouse

100 North Third Street

St. Charles, Missouri 63301

\section{COUNTY - St. Louis County}

Mr. G.R. "Buzz" Westfall

County Executive

St. Louis County

Administration Building, $9^{\text {th }}$ floor

41 South Central Avenue

Clayton, Missouri 63105

Mr. Lee Brotherton

Administration Building, $9^{\text {th }}$ floor

41 South Central

Clayton, Missouri 53105 
Conn Roden

County Health Department

111 South Meramec $2^{\text {nd }}$ Floor

Clayton, Missouri 63105

\section{CITY - Elected Officials - Mayor}

The Honorable Lee Barton

Mayor, City of Wentzville

Post Office Box 308

Wentzville, Missouri 63385

The Honorable Thomas W. Brown

Mayor, City of St. Peters

Post Office Box 9

St. Peters, Missouri 63376

The Honorable Clarence Harmon, Mayor

City of St. Louis

City Hall, Room 200

Market and Tucker Streets

St. Louis, Missouri 63103

The Honorable Edward W. Hajek, Jr.

Mayor, City of Lake St. Louis

1000 Lake St. Louis Boulevard Suite 16

Lake St. Louis, Missouri 63367

The Honorable Stephen Kochanski

Mayor, City of Cottleville

P.O. Box 387

Cottleville, Missouri 63338

The Honorable Donald D. Licklider

City of Weldon Spring

4950 Sammelmann Road

St. Charles, Missouri 63304 
The Honorable Robert L. Moeller

Mayor, City of St. Charles

St. Charles City Hall

200 North Second Street

St. Charles, Missouri 63301

The Honorable Paul F. Renaud

Mayor, City of O'Fallon

138 South Main Street

O'Fallon, Missouri 63366

CITY - Weldon Spring Heights Board of Trustees

Stephen A. McGuirk, Trustee (2 copies)

Catherine A. Davis, Trustee

$\% 5$ Weldon Spring Heights

St. Charles, Missouri 63304

Tom Gooch

Chairman of the Board of Trustees

32 Weldon Spring Heights

St. Charles, Missouri 63304

Mr. Larry D. Nesslage

Weldon Spring Heights

Board of Trustees

18 Weldon Spring Heights

St. Charles, Missouri 63304

Mr. Tom Lacey

Weldon Spring Heights

Board of Trustees

2 Weldon Spring Heights

St. Charles, Missouri 63304

Mr. Steven Heitkamp

Weldon Spring Heights

Board of Trustees

37 Weldon Spring Heights

St. Charles, Missouri 63304

DOE/OR/21548-730, Rev. 0 
Stephen Kiersch and Robert V Masek

Weldon Spring Heights

Board of Trustees

9 Weldon Spring Heights

St. Charles, Missouri 63304

FEDERAL AGENCY - U.S. Environmental Protection Agency

Mr. William Rice

U.S. Environmental Protection Agency

Region VII

726 Minnesota Avenue

Kansas City, Kansas 66101

Ms. Denise Jordan-Izaguire

Sr. Regional Representative

ATSDR c/0 EPA Region VII

726 Minnesota Avenue

Kansas City, Kansas 66101

Mr. Dan Wall (4 copies)

Superfund Division

U.S. Environmental Protection Agency

Region VII

726 Minnesota Avenue

Kansas City, Kansas 66101

FEDERAL AGENCY - U. S. Army Corps of Engineers

Steve Iverson

Program and Project Management Division

Atten: CEMRK-MD-H

U.S. Corps of Engineers

Kansas City District

601 East $12^{\text {th }}$ Street

Kansas City, Missouri 64106 
Mr. Mike Green CEMRK-ED-GH

Engineering Division

U.S. Army Corps of Engineers

601 East 12 Street

Kansas City, Missouri 64106

Mr. Karl J. Daubel

Environmental Coordinator

Weldon Spring Training Area

7301 Highway 94 South

St. Charles, Missouri 63304

Ray Allison

U.S. Corp of Engineers

7295 Highway 94 South

St. Charles, Missouri 63304

FEDERAL AGENCY - U.S. Department of Interior

Mr. Jim Barks

U.S. Geological Survey

1400 Independence Road

Mail Stop 200

Rolla, Missouri 65401

\section{Media Contact List}

Mr. William H. Allen, Science Writer

St. Louis Post-Dispatch

900 N. Tucker Blvd.

St. Louis, Missouri 63101

Dennis Miller \& Julie Gerke ( 2 copies)

St. Charles Journal

1529 Old Highway 94 South Suite 108

St. Charles, Missouri 63303 
Mr. Mike Trask

St. Charles Journal

1529 Old Highway 94 South

Suite 108

St. Charles, Missouri 63303

Mr. Tom Uhlenbrock

St. Louis Post-Dispatch

900 North Tucker Boulevard

St. Louis, Missouri 63101

Ms. Judith Vandewater

St. Charles Post

1355 South Fifth Street

St. Charles, Missouri 63301

Mr. Evan Forrester

KMOV-TV Channel 4

One Memorial Drive

St. Louis, Missouri 63102

\section{STATE AGENCY - Missouri Department of Natural Resources}

Mr. David A. Schorr

Director, Missouri Department of Natural Resources

Post Office Box 176

Jefferson City, Missouri 65102

Mr. Robert Geller ( 5 copies)

Missouri Department of Natural Resources

Post Office Box 176

Jefferson City, Missouri 65102

Mr. Larry Erickson

Missouri Department of Natural Resources

Post Office Box 176

Jefferson City, Missouri 65102 
Mr. Glenn Carlson

Missouri Department of Natural Resources

7045 Highway 94 South

St. Charles, Missouri 63304

\section{STATE AGENCY - Missouri Department of Conservation}

Dan Dickneite

Planning Division Chief

Missouri Department of Conservation

Post Office Box 180

Jefferson City, Missouri 65102-0180

STATE AGENCY - August A. Busch Memorial Wildlife Area

Mr. Mike Schroer, Manager

August A. Busch Memorial Wildlife Area

Route 2, Box 223

St. Charles, Missouri 63304

Mr. Jim Garr

August A. Busch Memorial Wildlife Area

Route 2, Box 223

St. Charles, Missouri 63304

\section{STATE AGENCY - Missouri Department of Health}

Mr. Gale Carlson

Environmental Specialists IV, MPA

Bureau of Environmental Epidemiolgy

Missouri Department of Health

Post Office Box 570

1730 East Elm

Jefferson City, Missouri 65102 


\section{STATE AGENCY - Fish and Wildlife Research Center}

Mr. Gary Novinger

Fish and Wildlife Research Center

Missouri Department of Conservation

1110 College Avenue

Columbia, Missouri 65201

\section{STATE/COUNTY WATER (point of contact)}

Mr. Thomas Aaron

St. Charles County Water Department

1635 South Highway 94

Defiance, Missouri 63341

Mr. Lynn Bultman, Manager

Missouri American Water Company

1290 Motherhead Road

P.O. Box 390

Cottleville, Missouri 63338-0390

Mr. Roger Dunajcik, Environmental Sanitarian

St. Charles County Health Department

305 N. Kingshighway

St. Charles, Missouri 63301

Mr. Terry Gloriod

Vice President for Production

St. Louis County Water Department

535 North New Ballas Road

St. Louis, Missouri 63141

Mr. Dave Visintainer

City of St. Louis Water Division

Chain of Rocks Plant

10450 Riverview Drive

St. Louis, Missouri 63137 
Mr. Ken Hogan

City of St. Louis Water Division

Howard Bend Plant

14769 Olive

Chesterfield, Missouri 63017

Mr. Jerry J. Brabander

Field Supervision

U.S. Fish and Wildlife Service

Columbia Field Office

608 Cherry Street

Columbia, Missouri 65201

FEDERAL - US. DOE - Headquarters

James J. Fiore, EM42

Director, Office of Eastern Area Programs

U.S. Department of Energy

19901 Germantown Road

Germantown, MD 20874

James M. Owendoff, EM40

Forrestal Building

U.S. DOE room 5 b050

1000 Independence Avenue SW

Washington, DC 20585-0113

Mr. Jim Wagoner, EM-421

Director, Off-Site Programs Division

U.S. Department of Energy

Division Cloverleaf

19901 Germantown Road

Germantown, Maryland 20874-1290

Mr. Robert Boettner, WSSRAP Offsite Mgr.Div

Cloverleaf Building, EM-421

U.S. Department of Energy

19901 Germantown Road

Germantown, Maryland 20874-1290 


\section{FEDERAL - U.S. DOE - Oak Ridge}

Mr. Steven L. Wyatt (3copies)

U.S. Department of Energy

Oak Ridge Operations Office

Public Information Office, Rm 102

Turnpike Bldg.

Post Office Box 2001

Oak Ridge, Tennessee 37831-8052

Mr. Rod Nelson, EW-90

Assistant Manager for Environmental Management

Oak Ridge Operations Office

U.S. Department of Energy

Post Office Box 2001

Oak Ridge, Tennessee 37831-8545

Distribution

Office of Scientific and Technical Information

U.S. Department of Energy

Post Office Box 62

Oak Ridge, Tennessee 37830

Mr. Peter J. Gross, SE-32

Environmental Protection Division

Oak Ridge Operations FB/2209

U.S. Department of Energy

Post Office Box 2001

Oak Ridge, Tennessee 37831-8730

Mr. J.C. Hall, Manager

Oak Ridge Field Office FB/3022

U.S. Department of Energy

Post Office Box 2001

Oak Ridge, Tennessee 37831-8738 
Manager for Environmental Safety and Quality

Oak Ridge Operations

U.S. Department of Energy

Post Office Box 2001

Oak Ridge, Tennessee 37831-8738

COUNTY - Libraries

Kisker Road Branch

St. Charles City/County Library

1000 Kisker Road

St. Charles, Missouri 63303

Spencer Road Branch

St. Charles City/County Library

425 Spencer Road

St. Peters, Missouri 63376

Kathryn M. Linneman Branch

St. Charles City/County Library

2323 Elm Street

St. Charles, Missouri 63301

Middendorf-Kredell Library

2750 Highway $\mathrm{K}$

O'Fallon, Missouri 63366

\section{COUNTY - School Districts}

Francis Howell School District

Mr. Donald J. McQueen, Consultant

Shannon \& Wilson Inc.

11500 Olive Blvd. Suite 3276

St. Louis, Missouri $63141-7126$

314-872-8170

Mr. Robert Shoewe, Principal

Francis Howell High School

7001 Highway 94 South

St. Charles, Missouri 63304 
Jerry Burbes

Francis Howell High School District

4545 Central School Road

St. Charles, Mo 63304

Dan Brown

Francis Howell High School District

4545 Central School Road

St. Charles, Missouri 63304

Lee Brittenham

Superintendent

Francis Howell School District

4545 Central School Rd.

St. Charles, Missouri 63304

\section{COUNTY - Weldon Spring Citizens Commission}

Ms. Helene Diller, Administrative Assistant

Weldon Spring Citizens Commission

100 North 3rd Street, Room 107

St. Charles, Missouri 63301

Shannon Dougherty

1 Strawgrass Court

St. Charles, MO 63304

Mr. Richard Hampel

3 Whiting Bay Court

St. Charles, MO 63304

Mr. Larry Sharp

2365 Canyon Drive

St. Charles, MO 63303

John Urbanowizc

Weldon Spring Citizens Commission

4231 Weatherton Place

St. Charles, Mo 63303

DOE/OR/21548-730, Rev. 0 
Ms. Daryl Anderson

Weldon Spring Citizens Commission

3129 Essex Drive

St. Charles, Missouri 63301

Mr. Glenn A. Hachey

Weldon Spring Citizens Commission

3441 Bluff View Drive

St. Charles, Missouri 63303

Mr. Paul Thomas Mydler

Weldon Spring Citizens Commission

2421 Chartom Mar

St. Charles, Missouri 63303

Ms. Nancy Dickens

150 East Dunn

Edwardsville, IL 62025

Other agencies/companies/organizations

Mr. Jerry Branbander

Columbia Field Office

S. Fish and Wildlife Service

608 E. cherry Street Room 207

Columbia, Missouri 65201

Mr. Bill Ferdinand

Quivra Mining Company

6305 Waterford Boulevard Suite 325

Oklahoma City, Ok 73118

Mr. Jack Stein, Director

Environmental Engineering \& Site Services Department

Anheuser Busch

One Busch Place

St. Louis, Missouri 63118 
Mr. Richard Hoormann, County Program Director

University of Missouri-Cooperative Extension Service

260 Brown Road

St. Peters, Missouri 63376

Ms. Jody Lally

Boston University School of Public Health

Environmental Health Department

Talbot 3C

80 East Concord

Boston, MA 02118

Mr. Mark Lusk

ASI

477 North Shoup Ave Suite 107

Idaho Falls, ID 83402

Ms. Mary Picel (4 copies)

EID Division

Argonne National Laboratory

9700 South Cass Avenue, Building 900

Argonne, IL 60439

Chris Byrne

Progam Manager--Air, Land, and Water

St. Louis County, Department of Health

111 S. Meramec

Clayton, Missouri 63105

Mr. Robert M. Wester, President

R.M. Wester and Associates, Inc.

215 Indacom Drive

St. Peters, Missouri 63376

\section{Stakeholders}

Charles and Robyn Ackerman

2771 Santa Ynez

St. Charles, Missouri 63303 
Glenn \& Lolle Boettcher

107 Summerset

St. Charles, Missouri 63304

Ms. Elaine Blodgett, Chair

4023 Graybridge East

St. Peters, Missouri 63376

Margaret Culver

202 Wolfrum Road

Weldon Spring, Missouri 63304

Mrs. Kay Drey

515 West Point Avenue

University City, Missouri 63130

Paul \& Jayne Ewalt

7133 Bentoak Court

Kirkwood, Missouri 63122

Mr. George Farhner

892 California Trail

St. Charles, Missouri 63304

Home: 314-928-7358

Ms. Teri Fricke

514 Woodmere Crossing

St. Charles, MIssouri 63303

Dr. Michael Garvey

208 Pitman Road

St. Charles, Missouri 63304

Ms. Martha Gill

7 Weldon Springs Heights

ST. Charles, Missouri 63304-5623

Mr. Andrew Gondzur

1260 Bentoak Court

Kirkwood, Missouri 63122 
Ms. Mary Halliday

3655 Highway D

Defiance, Missouri 63341

Ms. Gwen Hobbs

9 Spencer Trail

St. Peters, Missouri 63376

Ms. Jennifer Hobson

17 Upper Dardenne Farms Drive

St. Charles, Missouri 63304

Ms. Bobbie Judge

812 Saratoga Heights Drive

St. Charles, Missouri 63304

Ken Lawver

11500 N. Robinhood

Kansas City, Mo 64154

Mr. Brian Meyers

4714 Kelly Kris Court

St. Charles, Missouri 63304

Mr. Dave Mosby

222 N. $4^{\text {th }}$

St. Charles, Missouri 63301

Ms. Myrna Rueff

P.O. Box 250

Rolla, Missouri 65401

Ms. Phyllis Schneider

4601 Mid Rivers Mall Drive

St. Peters, Missouri 63376

Mr. Dale Schreiber

46 Broadview Drive

St. Louis, Missouri 63105 
Ms. Alicia Taylor

Morrison Knudsen

MK-Ferguson Plaza

1500 West $3^{\text {rd }}$ Street

Cleveland, Ohio 44113-1406

Mr. Brian Wilson

2 Birch

St. Peters, Missouri 63376

Ms. Rebecca Wright

1304 S. $18^{\text {th }}$ Street

St. Louis, Missouri 63104

Administrative Record

(1 Copies)

Distribution Count 154 